\title{
GEOLOGY REPORT
}

\section{AREA 3 RADIOACTIVE WASTE MANAGEMENT SITE DOE/NEVADA TEST SITE, NYE COUNTY, NEVADA}

\author{
Prepared By \\ Environmental Management \\ National Security Technologies ${ }^{\text {LLC }}$ \\ Las Vegas, Nevada
}

July 2006

Prepared for

U.S. Department of Energy

National Nuclear Security Administration

Nevada Operations Office

Work Performed Under Contract No. DE-AC52-06NA25946 


\section{Disclaimer}

Reference herein to any specific commercial product, process, or service by trade name, trademark, manufacturer, or otherwise, does not necessarily constitute or imply its endorsement, recommendation, or favoring by the United States Government or any agency thereof or its contractors or subcontractors.

\section{Availability Statement}

Available for sale to the public from-

U.S. Department of Commerce

National Technical Information Service

5285 Port Royal Road

Springfield, VA 22161

Phone: 800-553-6847

Fax: 703-605-6900

E-mail: orders@ntis.gov

Online ordering: http:/www.ntis.gov/ordering.htm

Available electronically at

http://www.osti.gov/bridge

Available for a processing fee to U.S. Department of Energy

and its contractors, in paper from-

U.S. Department of Energy

Office of Scientific and Technical Information

P.O. Box 62

Oak Ridge, TN 37831-0062

Phone: (865) 576-8401

Fax: (865) 576-5728

E-mail: reports@adonis.osti.gov 


\section{Abstract}

Surficial geologic studies near the Area 3 Radioactive Waste Management Site (RWMS) were conducted as part of a site characterization program. Studies included evaluation of the potential for future volcanism and Area 3 fault activity that could impact waste disposal operations at the Area 3 RWMS.

Future volcanic activity could lead to disruption of the Area 3 RWMS. Local and regional studies of volcanic risk indicate that major changes in regional volcanic activity within the next 1,000 years are not likely. Mapped basalts of Paiute Ridge, Nye Canyon, and nearby Scarp Canyon are Miocene in age. There is a lack of evidence for post-Miocene volcanism in the subsurface of Yucca Flat, and the hazard of basaltic volcanism at the Area 3 RWMS, within the 1,000 -year regulatory period, is very low and not a forseeable future event.

Studies included a literature review and data analysis to evaluate unclassified published and unpublished information regarding the Area 3 and East Branch Area 3 faults mapped in Area 3 and southern Area 7. Two trenches were excavated along the Area 3 fault to search for evidence of near-surface movement prior to nuclear testing. Allostratigraphic units and fractures were mapped in Trenches ST02 and ST03.

The Area 3 fault is a plane of weakness that has undergone strain resulting from stress imposed by natural events and underground nuclear testing. No major vertical displacement on the Area 3 fault since the Early Holocene, and probably since the Middle Pleistocene, can be demonstrated. The lack of major displacement within this time frame and minimal vertical extent of minor fractures suggest that waste disposal operations at the Area 3 RWMS will not be impacted substantially by the Area 3 fault, within the regulatory compliance period.

A geomorphic surface map of Yucca Flat utilizes the recent geomorphology and soil characterization work done in adjacent northern Frenchman Flat. The approach taken was to adopt the map unit boundaries (line work) of Swadley and Hoover (1990) and re-label these with map unit designations like those in northern Frenchman Flat (Huckins-Gang et al, 1995a,b,c; Snyder et al, 1995a,b,c,d). 


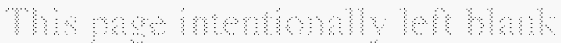




\section{Preface}

Surficial geologic studies near the Area 3 Radioactive Waste Management Site (RWMS) were conducted in Fiscal Years 1996 and 1997 as part of a site characterization program designed to satisfy the data needs of (1) the Low-Level Waste Performance Assessment required by U.S. Department of Energy (DOE) Order 5820.2A, Radioactive Waste Management (DOE, 1988) (now superseded by DOE O 435.1, Radioactive Waste Management [DOE 1999]; (2) the LowLevel Waste Composite Analysis required at DOE sites (DOE, 1996) in response to Recommendation 94-2 of the Defense Nuclear Facility Safety Board; and, (3) Resource Conservation and Recovery Act closure requirements pursuant to 40 Code of Federal Regulations 265.

A document entitled "Geology Report: Area 3 Radioactive Waste Management Site, DOE/Nevada Test Site, Nye County, Nevada" was prepared by Bechtel Nevada (BN) in January 1998 but was was never submitted for public release. This document supersedes the 1998 report.

As part of National Security Technologies ${ }^{\text {LLC }}$ (NSTec)'s current scope for closure planning for the Area 3 RWMS, this report has been updated to conform to the current editorial standards of NSTec and the DOE National Nuclear Security Administration Nevada Site Office. This document is being submitted for approval for public release so it will be accessible for public review and for citation in future documents.

\footnotetext{
' Superseded by DOE O 435.1 "Radioactive Waste Management" (DOE 1999).
} 
Thu mestmentmaly fermath 


\section{Executive Summary}

This report presents a summary of geologic studies undertaken by Bechtel Nevada during calendar year 1996 and fiscal year 1997 near the Area 3 Radioactive Waste Management Site (RWMS) at the U.S. Department of Energy (DOE) Nevada Test Site, Nye County, in southern Nevada.

Surficial geologic studies near the Area 3 RWMS were conducted as part of a site characterization program designed to satisfy the data needs of:

1. The Low-Level Waste Performance Assessment required by DOE Order 5820.2A, Radioactive Waste Management (DOE, 1988) (now superseded by DOE O 435.1, Radioactive Waste Management [DOE 1999];

2. The Low-Level Waste Composite Analysis required at DOE sites (DOE, 1996) in response to Recommendation 94-2 of the Defense Nuclear Facility Safety Board; and

3. The Resource Conservation and Recovery Act closure requirements in response to 40 Code of Federal Regulations 265.

Studies included evaluation of the potential for any future volcanism and activity of the Area 3 fault that would impact waste disposal operations at the Area 3 RWMS adversely.

Future volcanic activity is one potential scenario that could lead to disruption of the Area 3 RWMS. Local and regional studies of volcanic risk (Conner and Hill, 1995; Crowe et al, 1995; and Geomatrix Consultants, Inc., 1996) indicate that major changes in regional volcanic activity within the next 1,000 years are not likely. Based on the Miocene ages of the basalt of Paiute Ridge, Nye Canyon, and nearby Scarp Canyon, and the lack of evidence for post-Miocene volcanism in the subsurface of Yucca Flat, the hazard of basaltic volcanism at the Area 3 RWMS within the 1,000-year regulatory period is very low and not a forseeable future event.

A literature review and data analysis were undertaken to evaluate unclassified published and unpublished information about the Area 3 and East Branch Area 3 faults mapped in Area 3 and southern Area 7. Two trenches were excavated along the Area 3 fault to search for evidence of near-surface movement prior to nuclear testing. Allostratigraphic units and fractures, were mapped in Trenches ST02 and ST03.

The Area 3 fault is a plane of weakness that has undergone strain resulting from stress imposed by natural events, and more recently, by underground nuclear testing. No major vertical displacement on the Area 3 fault since the Early Holocene, and probably since the Middle Pleistocene, can be demonstrated by the continuity of alloformations in both Trenches ST02 and ST03. The lack of major displacement within this time frame, and minimal vertical extent of minor fractures, suggest that waste disposal operations at the Area 3 RWMS will not be substantially impacted by the Area 3 fault within the regulatory compliance period.

A geomorphic surface map was made of Yucca Flat that utilizes the recent geomorphology and soil characterization work done in adjacent northern Frenchman Flat (Plate 3). The approach 
taken was to adopt the map unit boundaries (line work) of Swadley and Hoover (1990) and relabel these with map unit designations like those in northern Frenchman Flat (Huckins-Gang et al, 1995a,b,c; Snyder et al, 1995a,b,c,d).

Description and analyses of soils in three trenches and across the landscape of Yucca Flat was integral to understanding the surficial geology in the vicinity of the Area 3 RWMS. Soil profile descriptions and characterization data were integral in establishing the allostratigraphy in the soil trenches. 


\section{Table of Contents}

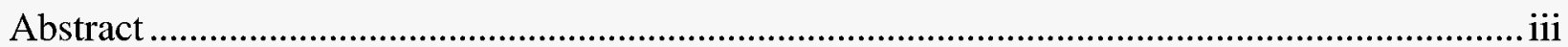

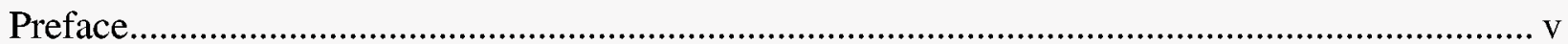

Executive Summary …….................................................................................................. vii

Acronyms And Abbreviations ............................................................................................... xiv

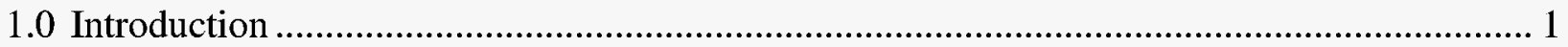

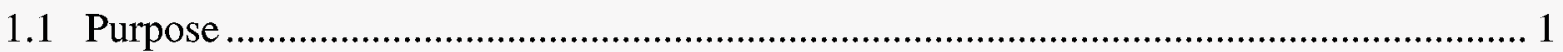

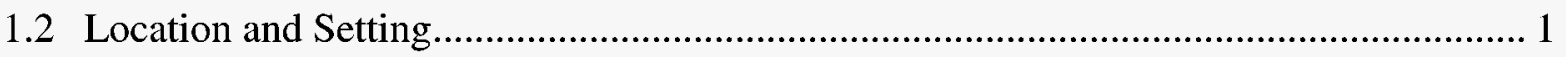

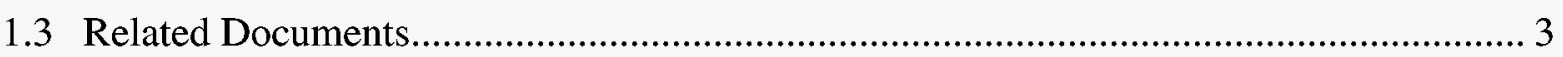

1.3.1 Flood Assessment ..................................................................................... 3

1.3.2 Area 3 Soil Characterization Database ............................................................. 3

1.3.3 Area 3 Hydrogeologic Characterization Borehole Reports................................... 4

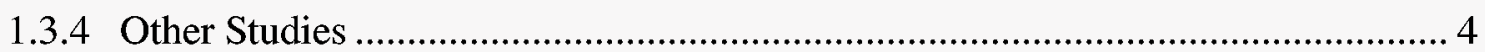

1.3.5 Hydrostratigraphic Model and Alternatives for Groundwater Flow and Contaminant Transport Model of Corrective Action Unit 97: Yucca Flat-Climax Mine, Lincoln and Nye

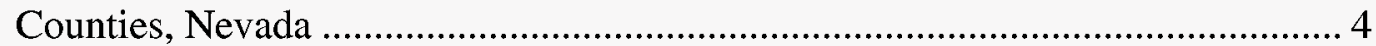

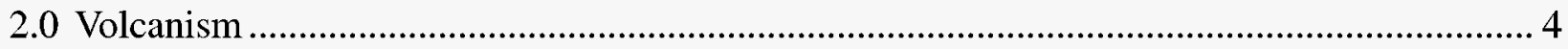

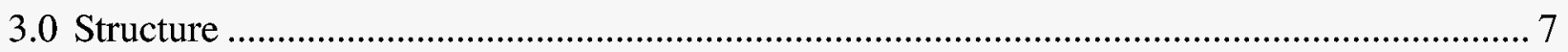

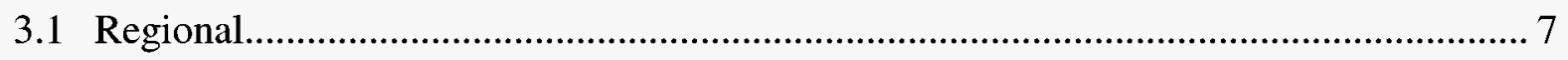

3.2 The Area 3 and East Branch Area 3 Faults.................................................................. 9

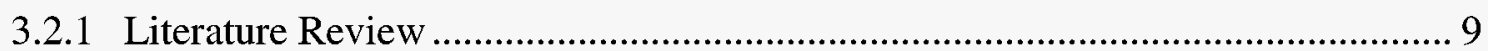

3.2.2 Current Surface Expression.............................................................................11

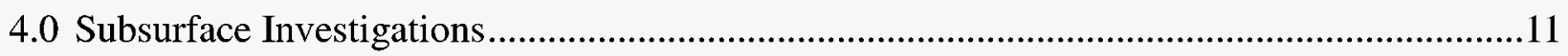

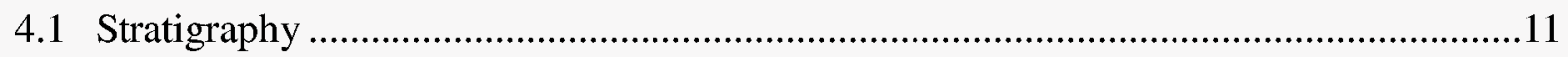

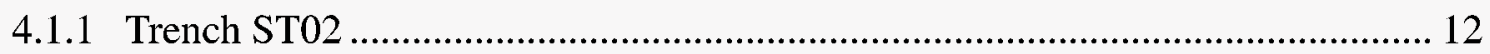

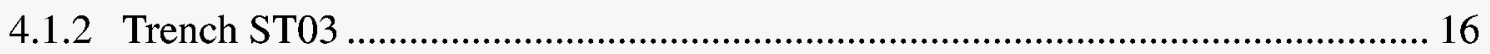

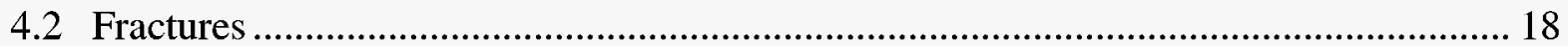

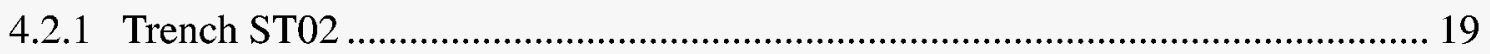

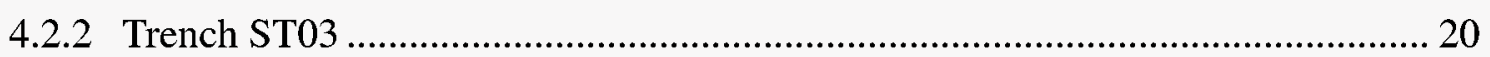




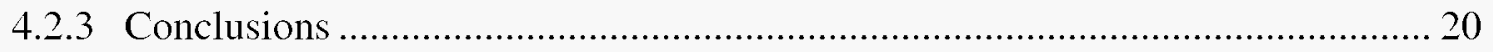

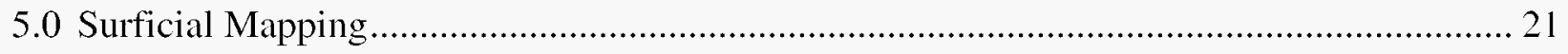

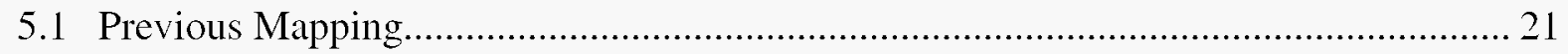

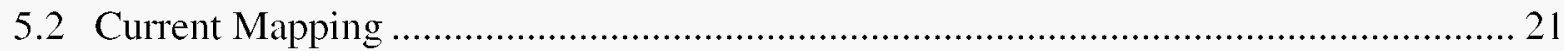

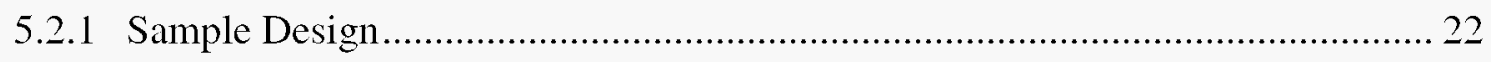

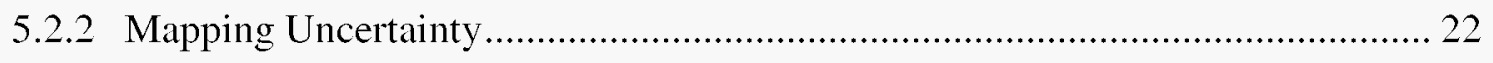

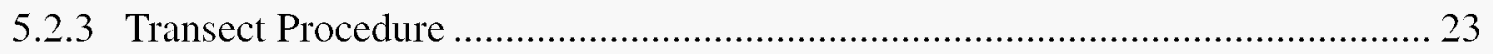

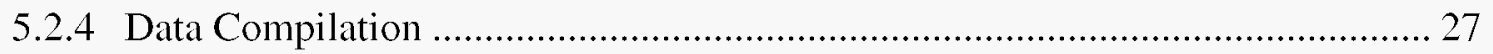

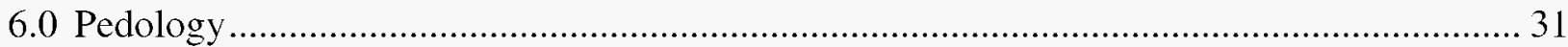

6.1 Profile Descriptions and Sample Analysis ................................................................... 31

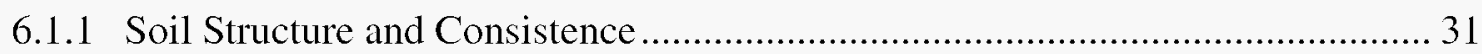

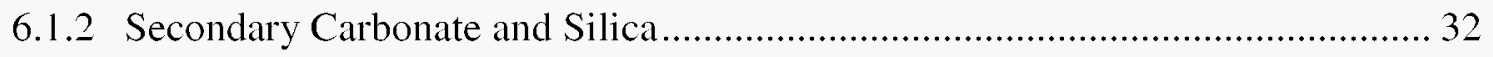

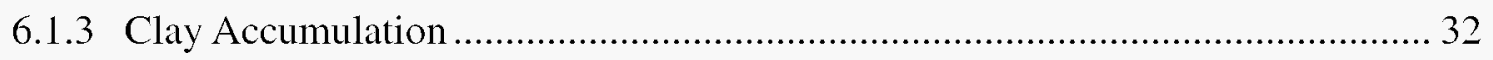

6.2 Relationship of Soils and Geomorphic Surfaces ......................................................... 33

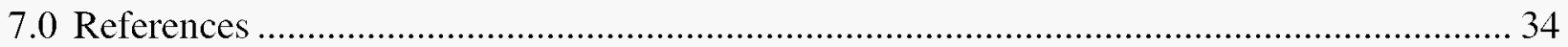




\section{Figures}

1-1. Location map and physiographic features of the Nevada

Test Site and the Area 3 RWMS................................................................................. 2

2-1. Post-caldera basalt of the Nevada Test Site region. ......................................................... 5

5-1. Transect point description form................................................................................... 26

B-1 Legend and Description for Trench Maps and Detail Maps .......................................... B-1

B-2a Stratigraphy and Geomorphic Surfaces of North Wall in Soil

Trench Two (ST02) Southeastern Yucca Flat ............................................................... B-2

B-2b Stratigraphy and Geomorphic Surfaces of North Wall in Soil

Trench Two (ST02) Southeastern Yucca Flat ................................................................. B-3

B-2c Stratigraphy and Geomorphic Surfaces of North Wall in Soil

Trench Two (ST02) Southeastern Yucca Flat .................................................................. B-4

B-2d Stratigraphy and Geomorphic Surfaces of North Wall in Soil

Trench Two (ST02) Southeastern Yucca Flat .................................................................... B-5

B-3 Detail Map of Fracture Zone between Stations $0+04$ and

$0+20$, Lower Level of Trench ST02 .................................................................... B-6

B-4a Stratigraphy of North Wall in Soil Trench Three (ST03)

Southeastern Yucca Flat ............................................................................................... B-7

B-4b Stratigraphy of North Wall in Soil Trench Three (ST03)

Southeastern Yucca Flat ...................................................................................... B-8

B-4c Stratigraphy of North Wall in Soil Trench Three (ST03)

Southeastern Yucca Flat ..................................................................................... B-9

B-4d Stratigraphy of North Wall in Soil Trench Three (ST03)

Southeastern Yucca Flat

B-4e Stratigraphy of North Wall in Soil Trench Three (ST03)

Southeastern Yucca Flat

B-5 Detail Map of Fracture Zone between Stations $0+40$ and

$0+50$, Lower Level of Trench ST03

B-6 Detail Map of Fracture Offsetting Beds near Station $2+46$ of

Trench ST03

B-7 Detail Map of Fracture Offsetting Beds near Station $2+70$ and

$2+79$, Lower Level of Trench ST03

E-1. OSL and Carbon-14 Sample Locations along North Wall

of Soil Trench Three (ST03) Central Yucca Flat

E-2. Synthesis of Late-Pleistocene, Holocene, and Possible Future

Climatic Variations Based on the work of Spaulding (1985)

E-3. Synthesis of Late-Pleistocene, Holocene, and Possible Future

Climatic Variations Based on the work of Spaulding (1985) 
E-4. Determination of sensitivity scaling factor. Scaling factor S

is the normalized OSL value for the intercept at $\mathrm{TL}=1$

(Example from Sample 6-4)

E-5. Relative attenuation of beta and gamma dose-rates with increasing water content

\section{Tables}

5-1. Summary of map unit differetiae of Swadley and

Hoover (1990)

5-2. Summary of map unit differentiae of Huckins-

Gang et al, 1995a,b,c; and Snyder et al, 1995a,b,c,d.

5-3. Final Correlation of Frenchman Flat geomorphic surface

units with surficial deposit units of Swadley and Hoover (1990) .............................. 28

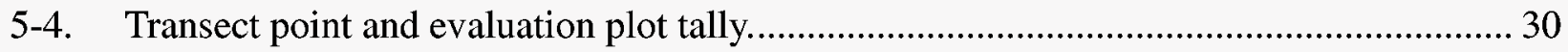

E-1. Gamma ray spectrometry results are shown in

Table 1 for bulk samples.

E-2. Cosmic ray dose-rate as function of sample depth

E-3. Beta and Gamma dose-rates (Gy/ka) for water

content $=0.0$ and beta attenuation due to finite grain size

E-4. Paleodose values (Gy). Weighted values are obtained by weighting individual dose measurements (D) in Tables (E-6 through E-11)

by the square of their propogated uncertainty $(\mathrm{sD})$.

E-5. Mean results of the Paleodose measurements for samples 3-3, 4-3, 5-4, and 6-4 all taken from the same layer of Aeolian sand

E-6. Paleodose values for individual measurements of Sample 1-1 ................................E-16

E-7. Paleodose values for individual measurements of Sample 2-2 .................................16

E-8. Paleodose values for individual measurements of Sample 3-3 .................................17

E-9. Paleodose values for individual measurements of Sample 4-3 ...................................17

E-10. Paleodose values for individual measurements of Sample 5-4 ................................ 18

E-11. Paleodose values for individual measurements of Sample 6-4 ....................................18

E-12. Age estimates (ka) as function of water content for all samples................................ 19 


\section{Appendices}

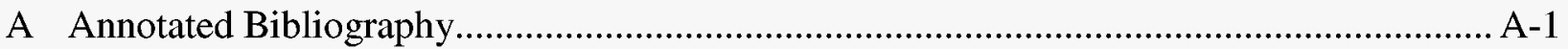

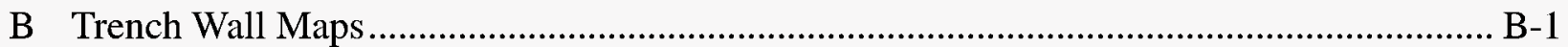

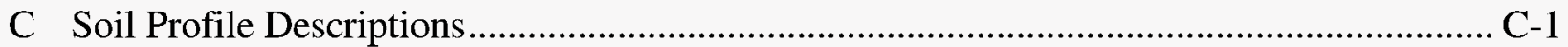

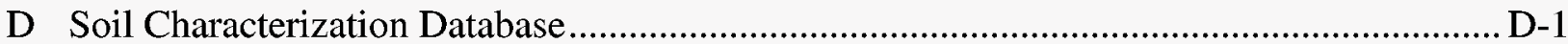

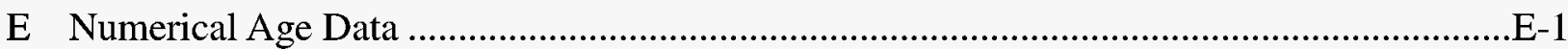

\section{Plates}

Plate 1. West-East geological Cross Section - Central Yucca Flat along Northing 841,500

Plate 2. Sequence to Testing-Induced Fractures Used to Delineate the Area 3 Fault

Plate 3. Geomorphic Surface Map of the Yucca Flat Area, Nye County, Nevada

Plate 4. Pretesting Lineaments and Geophysically Inferred Faults from Previous Studies

Plate 5. Isopach Map of Alluvium in LANL use Areas, Yucca Flats, NTS 


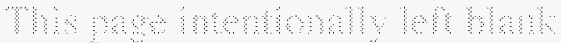




\section{Acronyms and Abbreviations}

\begin{tabular}{|c|c|}
\hline $\mathrm{BN}$ & Bechtel Nevada \\
\hline $\mathrm{C}$ & Celsius \\
\hline CFVZ & Crater Flat Volcanic Zone \\
\hline CFR & Code of Federal Regulations \\
\hline $\mathrm{cm}$ & centimeter \\
\hline DOE & U. S. Department of Energy \\
\hline $\mathrm{F}$ & Fahrenheit \\
\hline FEMA & Federal Emergency Management Agency \\
\hline $\mathrm{ft}$ & foot, feet \\
\hline FY & fiscal year \\
\hline hr & hour \\
\hline in. & inches/inch \\
\hline $\mathrm{ka}$ & thousand years ago \\
\hline $\mathrm{km}$ & kilometer, kilometers \\
\hline $\mathrm{km}^{2}$ & square kilometers \\
\hline $\mathrm{kt}$ & kilotons \\
\hline LLW & low level waste \\
\hline $\mathrm{Ma}$ & million years ago \\
\hline $\mathrm{m}$ & meters \\
\hline mi & mile, miles \\
\hline $\mathrm{mi}^{2}$ & square miles \\
\hline $\mathrm{mm}$ & millimeter(s) \\
\hline NIST & National Institute of Standards and Technology \\
\hline NSTec & National Security Technologies ${ }^{\text {LLC }}$ \\
\hline NTS & Nevada Test Site \\
\hline OSL & optically stimulated luminescence \\
\hline RCRA & Resource Conservation and Recovery Act \\
\hline RWMS & Radioactive Waste Management Site \\
\hline USGS & United States Geological Survey \\
\hline YPB & younger post-caldera basalt \\
\hline
\end{tabular}


This page intentondly leh buk 


\subsection{INTRODUCTION}

This report presents a summary of geologic studies undertaken by Bechtel Nevada during calendar year 1996 and fiscal year (FY) 1997 near the Area 3 Radioactive Waste Management Site (RWMS) at the U.S. Department of Energy (DOE) Nevada Test Site (NTS), Nye County, in southern Nevada. The Area 3 RWMS covers approximately 20 hectare 50 acre with three disposal cells located within the facility boundary. Two of the waste-management cells each consist of two collapse sinks (craters) that have been joined to make one large, oval-shaped landfill cell. The third cell is a single collapse sink (Figure 1). Disposal cell U-3ax/bl has been operationally closed under Resource Conservation and Recovery Act (RCRA) Interim Status. Disposal cell U-3ah/at continues to receive bulk low-level waste (LLW) that is disposed using conventional landfill techniques. Disposal cell $\mathrm{U}$ 3bh has received only uncontainerized plutonium-contaminated soil from DOE Nevada environmental restoration projects. In addition, there are two sinks within the facility boundary that have not been used.

\subsection{Purpose}

Surficial geologic studies near the Area 3 RWMS were conducted as part of a site characterization program designed to satisfy the data needs of:

1. The LLW Performance Assessment required by DOE Order 5820.2A, Radioactive Waste Management (DOE, 1988);

2. The LLW Composite Analysis required at DOE sites (DOE, 1996) in response to Recommendation 94-2 of the Defense Nuclear Facility Safety Board; and

3. The RCRA closure requirements in response to 40 Code of Federal Regulations (CFR) 265.

\subsection{Location and Setting}

The Area 3 RWMS is located in Yucca Flat, within the northeast quadrant of the NTS (Figure 1). The Yucca Flat watershed is a structurally closed basin encompassing an area of approximately 300 square miles $\left(\mathrm{mi}^{2}\right)\left(780\right.$ square kilometers $\left.\left[\mathrm{km}^{2}\right]\right)$. The ground surface within Yucca Flat slopes primarily from north to south toward Yucca Lake. The surface slope is approximately 1 percent at the Area 3 RWMS.

Yucca Flat is bound to the north by Quartzite Ridge and Rainier Mesa, to the east by the Halfpint Range, to the south by the Massachusetts Mountains and Control Point Hills, and to the west by Mine Mountain and the Eleana Range. The surrounding mountains consist primarily of Paleozoic sedimentary and Tertiary volcanic rocks. The generalized stratigraphic section of the basin is Quaternary and Tertiary alluvium over Tertiary rocks that, in turn, overlie Paleozoic rocks. The major structural features of the basin are north-south trending faults, including the Carpetbag fault, Yucca fault, and associated splays (Frizzel and Shulters, 1990). 


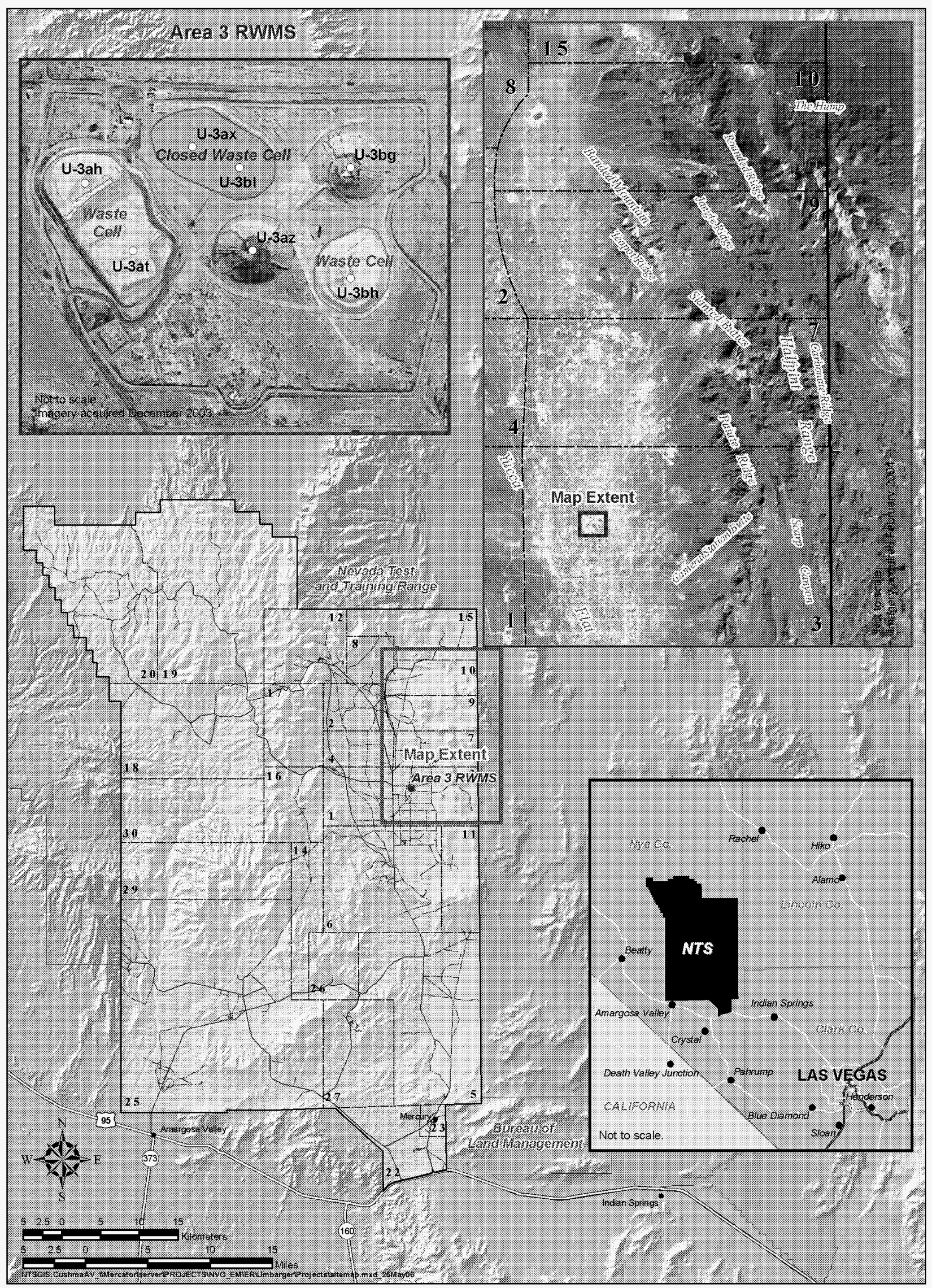

Figure 1. Location map and physiographic features of the Nevada Test Site and the Area 3 RWMS. 
Climate at the NTS is characterized by low precipitation, a large diurnal temperature range, low humidity, high evaporation rates, and moderate to high winds. Annual precipitation at lower elevations, such as Yucca Flat (3,920 ft [1,195 meters $(\mathrm{m})])$, averages 6 inches (in.) (150 millimeters [mm]). The Area 3 RWMS is located at an elevation of 4,020 ft. $(1,225 \mathrm{~m})$. Average daily maximum and minimum temperatures at Yucca Flat are 51E Fahrenheit (F) and 21EF (11E Celsius [C] and -6EC) in January and 96EF and 57EF (36EC and 14EC) in July (DOE, 1995). Average relative humidity at the Area 3 RWMS during 1996 ranged from 47 percent in February to 14 percent in June (D. G. Levitt, Personal Communication, 1996). Annual potential evaporation is approximately ten times greater than annual precipitation (French, 1993). Average annual wind speed in Yucca Flat is 7 miles (mi)/hour (hr) (11 kilometers [km]/hr) (Quiring, 1968). The prevailing wind direction during the winter is north-northwesterly, and during the summer, it is south-southwesterly.

The two major vegetation types within Yucca Flat are the Coleogyne and Grayia-Lycium Associations. A major species in the Coleogyne Association is Coleogyne ramosissima (blackbrush). Major species in the Grayia-Lycium Association, which predominates, are Grayia spinosa (hopsage) and Lycium andersonii (desert thorn).

\subsection{Related Documents}

Site characterization studies at the Area 3 RWMS related to the surficial geology studies summarized in this report are presented in several other documents. These documents are briefly summarized below.

\subsubsection{Flood Assessment}

A flood assessment was conducted at the Area 3 RWMS (Miller, 1996). This study was conducted to determine whether the Area 3 RWMS was located within a 100-yr flood hazard, as defined by the Federal Emergency Management Agency (FEMA), and to provide both 100- and 500-yr discharges for design of flood protection. The study area encompassed the approximately $300-\mathrm{mi}^{2}\left(780-\mathrm{km}^{2}\right)$ watershed of Yucca Flat, but focused on an approximately $36-\mathrm{mi}^{2}\left(94-\mathrm{km}^{2}\right)$ drainage area that could impact the Area 3 RWMS directly. The flood assessment determined that the Area 3 RWMS is not located within a FEMA-designated 100-yr. 6-hr flood hazard zone.

\subsubsection{Area 3 Soil Characterization Database}

A document was compiled that presents the database of a soil characterization study conducted at the Area 3 RWMS (Van Remortel et al, 1997). The database is maintained in a Microsoft ${ }^{\circledR}$ Excel $^{\odot}$ Version 5.0 for Windows ${ }^{\mathrm{TM}}$ spreadsheet that can be transferred into other spreadsheet or database formats. Column fields include both descriptive field data and analytical laboratory data. Methods used to produce the analytical laboratory data are described in Snyder and others (1996). Quality assurance criteria used to evaluate the quality of the data are described in Byers and others (1996). 


\subsubsection{Area 3 Hydrogeologic Characterization Borehole Reports}

Four data reports were compiled that contain detailed characterization of the hydrogeologic properties and processes of the alluvium at the Area 3 RWMS (Schmeltzer et al, 1996; Bechtel Nevada, 1998a,b,c). These reports were compiled from data collected through drilling and sampling of seven boreholes at the Area 3 RWMS. Core segments from the boreholes were used for measurement of the current moisture status; laboratory analyses for physical and hydraulic characteristics; and measurement of chloride, tritium, and stable isotope concentrations.

\subsubsection{Other Studies}

Later studies conducted to characterize the site of the Area 3 RWMS include the Characterization Report for Corrective Action Unit 110: Area 3 U-3ax/bl disposal Unit Nevada Test Site, Nevada (DOE/NV-580, BN 1999); the Site Characterization Data from the U3-ax/bl Exploratory Boreholes at the Nevada Test Site (DOE/NV/11718-003-REV.1, BN 2005b); and Potential Groundwater Recharge and the Effects of Soil Heterogeneity on Flow at Two Radioactive Waste Management Sites at the Nevada Test Site (DOE/NV/11718-609; Levitt and Yucel, 2002). These studies, along with this report, provided data that were used in the creation of a new, hydrostratigraphic model to be used for a better understanding of the groundwater flow and contaminant transport properties of the area.

\subsubsection{Hydrostratigraphic Model and Alternatives for Groundwater Flow and Contaminant Transport Model of Corrective Action Unit 97: Yucca Flat-Climax Mine, Lincoln and Nye Counties, Nevada}

In January 2006, a Phase I, 3-dimensional hydrostratigraphic framework model was constructed for the Yucca Flat-Climax Mine area of the NTS. The model will be used to develop groundwater flow and contaminant transport models for the underground nuclear testing areas in this area. The model encompassed a buffer surrounding the corrective action unit that includes important rock outcrop and drill-hole control that help constrain geologic interpretations, including Area 3.

\subsection{VOLCANISM}

Future volcanic activity is one potential scenario that could lead to disruption of the Area 3 RWMS. There has been no volcanic activity near the Area 3 RWMS since the late-Miocene. However, multiple Quaternary volcanic centers are present near Yucca Mountain, located approximately $26 \mathrm{mi}(42 \mathrm{~km}$ ) southwest of the Area 3 RWMS (Figure 2 ) (Crowe et al, 1998). Extensive investigations have been conducted by the Yucca Mountain Project for over a decade to assess the probability and consequences of future volcanic activity for the Yucca Mountain site. While these analyses have been designed to be specific to the Yucca Mountain area, the results can be used indirectly to bound the probability of future volcanic activity at the Area 3 RWMS. In addition, volcanic rock samples collected and analyzed (B. D. Turrin, D. E. Champion, and D. L. Gustafson, unpublished data) as part of the Area 5 RWMS Greater Confinement Disposal Performance Assessment were also used in this study. 

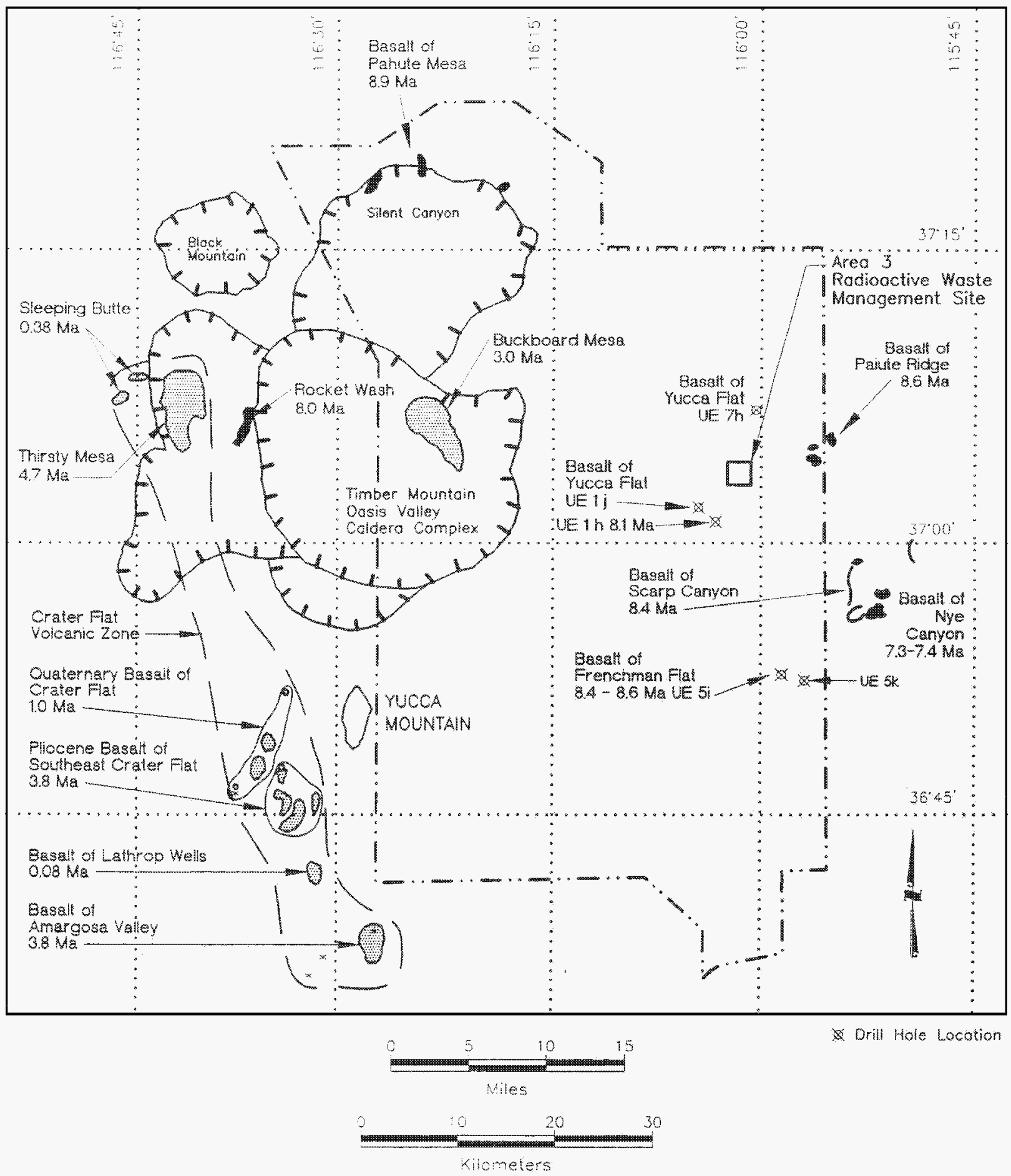

Wrill Hole Locotion

Figure 2-1. Post-caldera basalt of the Nevada Test Site region. Shaded areas are the Older Post-Caldera Basalt. Stippled areas are the Younger Post-Caldera Basalt. Asterisks mark aeromagnetic anomalies identified as potential buried basalt centers or intrusions. Ages estimated in millions of years. Modified from Crowe et al, 1998.

The two aspects to assess the risk of volcanism in the NTS region are, future silicic volcanic activity, and future basaltic volcanic activity. Hazards of silicic volcanism are negligible for several reasons (Crowe et al, 1983): 
- Quaternary silicic volcanism is restricted to the eastern and western margins of the Great Basin.

- Silicic volcanism has been absent in the NTS region for the last 8.5 million years.

- Within the last 10 to 20 million years, there has been a dramatic decrease and, in most areas, a cessation of silicic volcanism within the central and southern parts of the Great Basin.

There are no Pliocene or younger silicic volcanic centers within a 31-mi $(50-\mathrm{km})$ radius of the Area 3 RWMS. No site-specific data at or near Yucca Flat have been found in the literature or through field investigations that would alter the above interpretation of silicic volcanism near the Area 3 RWMS.

A transition from predominantly silicic volcanism to predominantly basaltic volcanism occurred approximately 10 million years ago (Ma) (Christiansen and Lipman, 1972). The probability of magmatic disruption of the Yucca Mountain site has been studied by multiple organizations. The mean probability estimates are 1.8 x 10-8 events yr- 1 (Crowe et al, 1995), 1.5 x 10-8 events yr-1 (Geomatrix Consultants, Inc., 1996), and $1 \times 10^{-8}$ to $5 \times 10^{-8}$ events $\mathrm{yr}^{-1}$ (Connor and Hill, 1995). These probability estimates can be applied to the Area 3 RWMS using the following assumptions:

- The areas of maximum hazards of basaltic volcanism are in spatial and structural zones of Pliocene and Quaternary basaltic volcanism (Crowe et al, 1998). The Area 3 RWMS is located outside of all these spatial and structural volcanic zones.

- The background probability of magmatic disruption of areas outside of the Pliocene and Quaternary volcanic zones is less than about $3 \times 10^{-9}$ events $\mathrm{yr}^{-1}$ (Crowe et al, 1998). Thus, the probability of magmatic disruption of the Area 3 RWMS is less than $3 \times 10^{-9}$ events $\mathrm{yr}^{-1}$.

Field investigations and drillhole studies suggest that shallow basalt intrusions are rare in the geologic record of the southern Great Basin (Crowe et al, 1986). Based on the analysis of previous basaltic volcanism in the NTS region, there is no evidence of evolution toward either an increase in the volcanic rate or the development of a large-volume volcanic field (Crowe et al, 1986).

The nearest basalt exposed at the land surface to the Area 3 RWMS is the Paiute Ridge basalt, approximately $4 \mathrm{mi}(6 \mathrm{~km})$ to the northeast (Figure 2). The Paiute Ridge basalt consists of a complex network of mafic dikes, sills, and lopoliths (Ratcliff et al, 1994). This post-caldera basalt erupted approximately 8.6 Ma (Ratcliff et al, 1994).

In Yucca Flat, basalts were found in three drill holes: UElh, UElj, and UE7h (Figure 2). The depth of these basalts are:

- 740 to $1,010 \mathrm{ft}$ (226 to $308 \mathrm{~m}$ ) in UElh

- 1,360 to $1,400 \mathrm{ft}$ (415 to $427 \mathrm{~m}$ ) in UElj

- 2,440 to $2,510 \mathrm{ft}$ (744 to $765 \mathrm{~m}$ ) in UE7h

Potassium-argon analysis yielded a numerical age of $8.1 \forall 0.6 \mathrm{Ma}$ for the basalt encountered in drill hole UElh (Marvin et al, 1989). No ages are available for the basalts in UElj and UE7h.

There was a regional hiatus in volcanic activity after eruption of the basalt of Nye Canyon, located approximately $12 \mathrm{mi}(19 \mathrm{~km})$ southeast of the Area 3 RWMS, with a numerical age of about 7.3 Ma (B. D. Turrin, D. E. Champion, and D. L. Gustafson, unpublished data). No 
volcanic rocks of the NTS region have yielded numerical ages in the range of 7.3 to $4.7 \mathrm{Ma}$ (Figure 2) (Crowe et al, 1998). The younger post-caldera basalt (YPB) includes all volcanic rocks younger than the basalt of Nye Canyon (Crowe, 1990). The nearest Quaternary basalt to the Area 3 RWMS is that of Crater Flat, approximately $32 \mathrm{mi}(51 \mathrm{~km})$ southwest of the Area 3 RWMS, with numerical ages of about 1.0 Ma (Figure 2) (Crowe et al, 1998).

Crowe and Perry (1989) defined a narrow northwest-trending zone called the Crater Flat Volcanic Zone (CFVZ) that encompasses all the YPB centers, with the exception of the basalt of Buckboard Mesa (Figure 2). Crowe (1990) concluded the formation of a new volcanic center or cluster of centers has a finite probability of occurring at the NTS, with the most likely area of formation being in the CFVZ. The Area 3 RWMS is located outside of the CFVZ.

Local and regional studies of volcanic risk (Conner and Hill, 1995; Crowe et al, 1995; and Geomatrix Consultants, Inc., 1996) indicate that major changes in regional volcanic activity within the next 1,000 yrs are not likely. Based on the Miocene ages of the basalt of Paiute Ridge, Nye Canyon, and nearby Scarp Canyon, and the lack of evidence for post-Miocene volcanism in the subsurface of Yucca Flat, the hazard of basaltic volcanism at the Area 3 RWMS within the 1,000 -yr regulatory period is very low and not a forseeable future event.

\subsection{STRUCTURE}

\subsection{Regional}

The structure and geomorphology of Yucca Flat is typical of intermontane basins occurring throughout the Basin and Range Province of Nevada and adjoining states. Faulted and tilted blocks of Tertiary volcanic rocks and underlying Paleozoic sedimentary rocks form low ranges on both sides of the basins. These ranges bound rotated and downdropped blocks in the basins. Erosion of the ranges over several millions of years has resulted in the deposition of a significant thickness of alluvium within the basin. The topography of the prealluvial surface and ongoing structural activity during alluvial deposition influence the present alluvium thicknesses. Midbasin alluvium thickness in southern Yucca Flat, for example, generally ranges from 100 to 2,300 $\mathrm{ft}$ (30 to $700 \mathrm{~m}$ ) (Drellack, 1994a).

The tectonic history, and thus present geometry, of rocks at the NTS is very complex. The preTertiary rocks were significantly deformed in Late Mesozoic time (the Sevier Orogeny). In western Yucca Flat and CP Hills, portions of the Paleozoic section are repeated as a result of Mesozoic thrust faulting. Thrust faults identified in the NTS vicinity include the Mine Mountain and CP thrusts in the Yucca Flat area, the Specter Range thrust west of Mercury, and the Spotted Range thrust east of Mercury. Most plates were transported eastward with displacements on the order of 10s of kilometers (Orkild, 1983). In Miocene to Quaternary times, these Paleozoic rocks and the overlying volcanic units were disrupted by large-scale extensional block faulting that is largely responsible for the present Basin and Range topography.

The resultant structural setting of Yucca Flat is best shown in a west-east cross section (Plate 1). Fault locations are based primarily on drill hole data (Drellack and Thompson, 1990), as well as derivative isopach and structure contour maps (Drellack, 1995a). Geophysical data (i.e., gravity, seismic, and magnetic) were used, especially where drillhole data are sparse. Some faults can be projected to the surface and correlated with the trends of cracks on a postshot surface effects 
compilation map (U.S. Geological Survey [USGS], unpublished map, 1:12,000 scale). Many of these "younger" faults (e.g., the Yucca fault) displace younger features such as the top of zeolitization (Drellack, 1995b) or internal bedding within the deeper alluvium (Elwood et al, 1985). Other faults, considered "older," are not readily discernable on either surface effects maps or the top of zeolitization contour maps.

Most of the displacement on these faults is dip-slip; however, a right-lateral, strike-slip component of motion also has been documented (Ferguson, 1981). Vertical displacements on these normal faults ranges from approximately $2,000 \mathrm{ft}(610 \mathrm{~m})$ on the main basin-forming faults to less than $50 \mathrm{ft}(15 \mathrm{~m})$ on the lesser faults. Unless other information is available, the highangle normal faults are assumed to have a true dip of about 70 degrees $\left(^{\circ}\right.$ ).

There is evidence that Basin and Range crustal extension occurred in at least two stages across the NTS. The early phase, about 16 to $14 \mathrm{Ma}$, consisted of high-angle northwest- and northeasttrending normal (including detachment) faults, whereas the later phase, younger than $11 \mathrm{Ma}$, consisted of slightly steeper dipping north-south trending normal faults. The earlier phase is thought to be responsible for several minor topographical troughs discernable on isopach maps of older ash-flow units and for the recently reinterpreted low-angle faults in the Mine Mountain area (Cole et al, 1989). The later phase is responsible for the present basin-forming faults (Dockery-Ander, 1984).

Displacement of the Paleozoic rocks by high-angle Tertiary faults is assumed to be about the same as that of the overlying volcanic section. In parts of Yucca Flat, downhole photography reveals steepening of bed dips with depth, indicating intermittent displacement over time.

The principal basin-forming faults in Yucca Flat are the Yucca fault and the Carpetbag fault, both east-dipping, moderately high-angle normal faults. The Yucca fault is located in the east-central portion of the basin. It trends north-south and extends the entire length of the valley. The Carpetbag fault also strikes north-south and is located in the western part of the valley. Toward the south, the Carpetbag fault steps eastward in an en echelon fashion to become the Topgallant fault. The Carpetbag fault represents the eastern side of a large north-south trending buried horst of Paleozoic carbonate rocks (also referred to as the "Gravity High"). This horst separates the large main basin on the east from several smaller subbasins on the west.

Age estimates for these youngest faults has been the focus of several studies (Knauss, 1981; Shroba et al, 1988). Knauss (1981) brackets the age of the last natural movement along the Carpetbag fault between 37 and 93 thousand years ago (ka), and along the Yucca fault at less than $35 \mathrm{ka}$. Shroba and others (1988) conclude that no significant natural vertical surface displacement has occurred along the Carpetbag system during the past 125,000 to 350,000 years.

The nearest known fault to the Area 3 RWMS passes through the eastern margin of the facility and is called the Area 3 fault. The projected surface trace of this fault is assumed to follow a minor, but persistent, trend of postshot surface fractures. Available information suggests that the Area 3 RWMS is located on a structural block that is bounded on the east by the west-dipping Area 3 fault and on the west by the east-dipping Yucca fault (Plate 1). 


\subsection{The Area 3 and East Branch Area 3 Faults}

\subsubsection{Literature Review}

A literature review and data analysis were undertaken to evaluate unclassified published and unpublished information regarding the Area 3 and East Branch Area 3 faults mapped in Area 3 and southern Area 7. This work focused on determining how, and by who, the surface traces of the Area 3 fault and East Branch Area 3 fault were recognized; and whether geophysical and borehole data corroborate the surface expression of these mapped features. The annotated bibliography (Appendix A) is summarized in this section.

The Area 3 fault was first mapped and named by Williams and others in 1963 (Appendix A, Entry 7 ) as a zone of surface fractures caused by the BILBY (U3cn) and BANDICOOT (U3bj) tests (Plate 2). Some fractures had up to 6 in. (15 centimeters ([cm]) of vertical offset. The predominant sense of motion was to the west. (The term "fractures," as used during post-event mapping, included features with scarps and without scarps.) Surface mapping associated with subsequent tests added more fractures, extending the Area 3 fault trace farther northward. The USGS compilation map of surface effects (USGS, unpublished map, 1:12,000 scale; Appendix A, Entry 41) presents the most current representation of the Area 3 fault surface expression.

Not all test-induced fractures, even if observed, are shown on compilation maps, which represent the intermittent nature of post-event mapping.

Mapping of surface effects was first completed for the BANDICOOT test in September 1962 (Emerick, 1963; Appendix A, Entry 2) and became routine for tests from January 1964 through June 1966. After June 1966, surface effects were only mapped following select tests. For the section near the Area 3 fault, no published compilation maps or individual test maps were found for the period from April 1967 through October 1969, or from December 1975 to the present. A consequence of intermittent mapping is that some fractures may not be shown on any map. Notably, no surface effects were mapped in association with any tests within the boundaries of the Area 3 RWMS because these tests pre-date routine mapping of surface effects. For example, the RINGTAIL test (U3ak) in December 1961 resulted in a recognized zone of aligned fractures that were not mapped (Emerick, 1963; Appendix A, Entry 2).

Aerial photographs of Yucca Flat taken in 1951, prior to nuclear testing at the NTS, were studied by Morris (1965; Appendix A, Entry 19) to "determine the geological nature of the lineaments and whether they have any special or casual relation to explosion-produced fractures." The study revealed a 2,500-ft- (760-m)-long lineament east of emplacement hole U7b, near the northern end of the Area 3 fault, and a 12,000-ft- (3,660-m)-long curving lineament east of the Area 3 fault. When Morris transferred these lineaments to the then-current surface-effects map (Emerick et al, 1965; Appendix A, Entry 17), the result was the first hint of a wishbone-shaped fault system in Area 3 and southern Area 7. This was a north-south trace defined by testinginduced fractures and a pretesting lineament at the north end, and a curved east branch based on a pretesting lineament that was cracked along its entire length by nuclear testing (R. H. Morris, Personal Communication., 1996). In addition, weathered (presumably natural) scarps in Pleistocene alluvium were found along the Area 3 fault trace by Dickey (1968; Appendix A, Entry 29). In 1972, Snyder and Rogers (Appendix A, Entry 33) shortened Morris' curved, 
cracked lineament when they transferred it to their surface-effects map. They named this shortened lineament the "East Branch Area 3 fault."

National Geophysical Company (formerly Namco International, Inc.) conducted seismic surveys during the 1960s near the Area 3 RWMS (Appendix A, Entries 1, 4, 9, and 15). These seismic surveys are the source of the geophysically inferred faults shown on early surface-effects maps (Davis, 1964; Emerick and Davis, 1965; Morris, 1965; Corchary, 1966a,b; McKeown and Dickey, 1967; Appendix A, Entries 10, 17, 19, 23, 24, and 25, respectively). Faults mapped by National Geophysical Company are all interpreted as east-dipping normal faults, including a fault parallel to part of the Area 3 fault. The east-dipping normal fault interpretations are not supported by subsurface control. A comparison of drillhole data with structure contour maps from National Geophysical Company reports shows numerous inconsistencies. For example, reflectors mapped by National Geophysical Company show offset of $250 \mathrm{ft}(76 \mathrm{~m})$ on the Yucca fault, whereas drillhole data near the seismic surveys show the offset to be approximately $1,500 \mathrm{ft}(460 \mathrm{~m})$. These inconsistencies can be explained by incorrect velocities used to produce the structure maps, the poor quality of the seismic records, or a combination of both. Although cited by previous workers as evidence of the subsurface location of the Area 3 fault, this review of the National Geophysical Company data does not provide such conclusive geophysical evidence. Ferguson (1981; Appendix A, Entry 37) recorded a seismic line approximately $6,340 \mathrm{ft}(1,930 \mathrm{~m})$ south of the Area 3 RWMS. West-dipping normal faults are interpreted at the top of the Paleozoic section and within the Tertiary section near the southern projections of the Area 3 and East Branch Area 3 faults. However, no reflector provides evidence that these faults extend through the Quaternary alluvium to the surface.

Gravity studies by Healey (1963) and Hazelwood and others (1963) (Appendix A, Entries 5 and 6 , respectively) recorded a gravity high and low at the north end of the Area 3 fault. One interpretation is that the gravity high and low may be on the west and east sides, respectively, of the northern projection of the fault. Thus, the gravity low would represent a block of pre-Cenozoic rocks downdropped to the east relative to the adjacent rocks to the west (the gravity high). Alternatively, the gravity high and low could result from a mechanism not related to faulting; for example, paleotopography or differing lithologies. Although numerous, closely spaced faults have been mapped within the Tertiary section in this area (Drellack, 1994; Appendix A, Entry 40), no Cenozoic high is apparent from drill hole data.

Detailed subsurface characterization near the Area 3 fault is precluded by a paucity of deep drillholes in that area. However, two drill holes, U3cs and U3kx, which are approximately $1,000 \mathrm{ft}(300 \mathrm{~m})$ apart and on opposite sides of the Area 3 fault (Plate 2), show the top of the Rainier Mesa Tuff to be at an elevation of 3,183 and 2,900 ft (970 and $880 \mathrm{~m})$, respectively (Drellack, 1994b; Appendix A, Entry 40). Although the difference in elevation of $287 \mathrm{ft}$ ( $90 \mathrm{~m}$ ) can be interpreted as faulting down to the west, a second interpretation is a subsurface dip at the top of the Rainier Mesa Tuff of $16^{\circ}$ west along a line between the two drillholes. Tertiary rocks that crop out approximately $2 \mathrm{mi}(3 \mathrm{~km})$ to the east of the drill holes dip at $5^{\circ}$ to $15^{\circ}$ west.

Two trenches were dug across the surface trace of the Area 3 fault by the USGS in 1965 . These were mapped by Carr (1965; Appendix A, Entry 16), who noted fracturing, but did not observe a distinct fault in either. Trench D was approximately $10 \mathrm{ft}(3 \mathrm{~m})$ deep and crossed the northern part of the Area 3 fault $500 \mathrm{ft}(152 \mathrm{~m})$ southwest of U7b. Trench E was 5 to $10 \mathrm{ft}(1.5$ to $3 \mathrm{~m})$ deep and crossed the southern part of the fault $200 \mathrm{ft}(60 \mathrm{~m})$ north of the U3bj collapse sink. 
Whether the surface scarps and cracking were a result of subsurface movement on the Area 3 fault or differential compaction of alluvium over a subsurface scarp has been controversial and remains unresolved (S. L. Drellack, Jr., Personal Communication, 1995; App, 1985; Appendix A, Entry 39). Dickey (1968; Appendix A, Entry 29) conducted a survey along the Yucca fault prior to and after an underground nuclear test. The results of the survey indicated that bedrock was displaced and that the observed surface effects were not merely the result of differential compaction of the alluvium.

\subsubsection{Current Surface Expression}

Most test-induced fractures were short-lived features and are no longer evident on the landscape. However, three scarps that pre-date testing were observed in the field (Plate 2). One scarp along the Area 3 fault is immediately north of the intersection of the Area 3 fault and the East Branch Area 3 fault. Here, for approximately $600 \mathrm{ft}(183 \mathrm{~m})$, a Late Pleistocene or early Holocene surface is offset about $2 \mathrm{ft}(0.6 \mathrm{~m})$. This may be one of the "weathered west-facing scarp[s] about $2 \mathrm{ft}$ high" that Dickey (1968; Appendix A, Entry 29) reported. At this location in 1970, a 4-in- (10-cm)-high scarp was mapped as an effect of the TIJERAS test at U7y (E. C. Jenkins, oral comm., 1996). It is not discernable what part of the old scarp was reactivated.

The second scarp found along the Area 3 fault is approximately 1,500 $\mathrm{ft}(457 \mathrm{~m})$ northeast of drill hole U3cq, in a remnant of a Late Pleistocene or early Holocene surface. The scarp is much less than $1 \mathrm{ft}(0.3 \mathrm{~m})$ high, little more than a small break in slope. Presumably, the scarp predates nuclear testing because no testing-induced fractures with offset were mapped in this area, and the fan surface is undisturbed by human activity. In addition, the long axis of this ancient fan remnant is bound by drainages oriented subparallel to the zone of testing-induced fractures (without offset) mapped after the BILBY and CANVASBACK tests (Williams, 1964a,b; Appendix A, Entries 8 and 11).

The scarp along the East Branch Area 3 fault is about 4,500 $\mathrm{ft}(1,370 \mathrm{~m})$ south of its intersection with the Area 3 fault. This scarp is approximately $3 \mathrm{ft}(1 \mathrm{~m})$ high and offsets a Middle Pleistocene surface. Surface features (such as desert varnish and pavement) and near-surface soil horizons are continuous across the scarp, indicating the scarp is older than these features.

The USGS trenches excavated and mapped by Carr (1965; Appendix A, Entry 16) were not reviewed because the trenches were caved, or within an inaccessible area, or both.

\subsection{SUBSURFACE INVESTIGATIONS}

Subsurface investigations comprised stratigraphic and fracture analyses. The stratigraphic analysis consisted of mapping allostratigraphic units and lithofacies. The fracture analysis consisted of locating and tracing fractures and fracture zones, and identifying any offset of adjacent strata.

\subsection{Stratigraphy}

Two trenches were excavated along the Area 3 fault to search for evidence of near-surface movement prior to nuclear testing. Both trenches were excavated to a depth of $10 \mathrm{ft}(3 \mathrm{~m})$ with a 
bench on each side at $5 \mathrm{ft}(1.5 \mathrm{~m})$ below the ground surface. One trench, ST02, was dug across the scarp found closest to the Area 3 RWMS, which is the small slope break (and associated drainageways) near drill hole U3cq, $6,500 \mathrm{ft}(1,980 \mathrm{~m})$ northeast of the Area RWMS. This trench was approximately $280 \mathrm{ft}(85 \mathrm{~m})$ long, $15 \mathrm{ft}(5 \mathrm{~m})$ wide, and trended approximately $\mathrm{N} 60^{\circ} \mathrm{W}$. The second trench, ST03, was dug within the Area 3 RWMS and across the fault trace defined by surface fractures from the BANDICOOT test, a zone $140 \mathrm{ft}(43 \mathrm{~m})$ wide and trending N10 $-15^{\circ} \mathrm{E}$ (Emerick, 1963; Appendix A, Entry 2). Trench ST03 was approximately $440 \mathrm{ft}$ $(134 \mathrm{~m})$ long, $25 \mathrm{ft}(8 \mathrm{~m})$ wide, and trended approximately $\mathrm{N} 69^{\circ} \mathrm{W}$. The west end of Trench ST03 was approximately $200 \mathrm{ft}(60 \mathrm{~m})$ south of the center of the U-3bh collapse sink and approximately $600 \mathrm{ft}$ (183 m) north of USGS Trench E (Carr, 1965; Appendix A, Entry 16).

Allostratigraphic units and lithofacies were mapped along the entire north wall of both trenches (Appendix B). Soil profile descriptions were made at several locations in each trench. To facilitate subsurface mapping, level lines of known elevation and coordinates were established (surveyed) in each trench. Vertical measurements to various features were made using a stadia rod and the level lines. Locations along the mapped walls are referenced using the west end of each level line being station $0+00$.

Informal allostratigraphic units (which are defined and identified by bounding discontinuities) were mapped in both trenches. Four alloformations (designated W, X, Y and Z) were mapped in Trench ST02 and three (designated L, M and N) were mapped in Trench ST03. Each formation was labeled alphabetically from oldest to youngest in both trenches and no correlations were made between the two trenches. Bounding discontinuities of alloformations were associated with soils and disconformities of the present or buried land surface. Soils marking the upper contact typically possess horizons having significant accumulation of calcium carbonate (a calcic horizon with at least Stage II morphology [Gile et al, 1966]) or a significant accumulation of clay (an argillic horizon). Within several formations there are discontinuities marked at the upper contact by more weakly expressed soils (and truncated to varying degrees) that are joined laterally by a single recognizable and traceable disconformity. These discontinuities are interpreted as marking brief, but notable, periods of landscape stability, and divide the alloformation into an upper and lower member. These allomembers are designated by a number after the formation letter (e.g., N1 and N2); the larger the number the older the unit. Detailed soil profile descriptions are presented in Appendix $\mathrm{C}$, and physical and chemical laboratory data derived from soil profile samples are included in Appendix D.

Lithofacies used in mapping Trenches ST02 and ST03 (Appendix B, Appendix C) were the same as those used for pitwall and trench mapping at Area 5 (Snyder et al, 1993), except an additional unit was established for Area 3 mapping. Differentiation of lithofacies is based on sorting, grain size, clast abundance, and presence or absence of bedding. Factors controlling these features include primary influences such as stream power and pedogenesis. Within these lithofacies, there are sedimentological or pedogenic changes too small to map, but which were useful as marker beds or horizons in the detailed mapping of fractures. An additional trench (ST01) was not mapped for evidence of faulting. Soil profiles are included in Appendix C.

\subsubsection{Trench ST02}

\section{ALLOFORMATION W}

\section{Allomember W1}


This unit is present only at the very bottom and extreme western end of Trench ST02 (between stations $0+00$ and $0+55)$. It has a thickness of approximately $1 \mathrm{ft}(0.3 \mathrm{~m})$. The trench floor serves as its lower boundary and Allomember W2 as its upper boundary. The contact with Allomember W2 varies from abrupt to gradual and wavy to irregular, which is the result of incision by several stream channels from the W2 unit.

The upper boundary of Allomember W1 is marked by a paleosol developed in a pebbly ( 25 to 50 percent), matrix-supported alluvium. This pink to pinkish-gray (7.5 YR7-8/4-2, dry) truncated soil is typically loamy sand and characterized by a rigid, carbonate-cemented Bkm horizon (Stage III and Stage IV). Cementation is continuous and strong; many clasts broke in half versus being plucked from the matrix as the trench was excavated. Horizons adjacent to the Bkm are less cemented, but thin to thick pendants of carbonate on the bottom of clasts (Stage I+ to II+) are common and opaline silica laminae are present on some clasts. Cementation in these Bk horizons occurs as discontinuous bands or layers. Ooliths (globules) are common in some of these layers. The uppermost limit of this unit (and lateral margins where it is bounded by fractures $)$ is characterized by a discontinuous 1 -in.- $(2.5-\mathrm{cm})$-thick zone of laminated carbonate and silica.

\section{Allomember W2}

This member is found near the bottom of the trench between stations $0+00$ and $1+15,1+75$ and $1+90$, and $2+35$ and $2+60$. A thickness of 0.3 to $3.5 \mathrm{ft}(0.1$ to $1.1 \mathrm{~m})$ is exposed. Either the trench floor or unit W1 serve as the lower boundary, which is abrupt to gradual and wavy to irregular. Alloformation X or Y serve as the (abrupt and wavy) upper boundary.

The upper boundary of unit W2 is characterized by a paleosol developed in pebbly ( 35 to 55 percent), matrix- and clast-support alluvium. This truncated soil is typically sand to loamy sand and dominated by a pink (7.5YR8-7/3, dry) to pinkish-white (7.5YR8/2, dry) carbonatecemented Bkm or Btkm horizon (Stage III- to IV-). Cementation is continuous and strong. During excavation of the trench some clasts broke in half versus being plucked from the matrix. There is a discontinuous 0.04- to 0.08-in (1- to 2-mm) carbonate lamina at the upper contact and 0.04-in (1-mm) lamina recurring along major lateral fractures throughout the alluvium. Also present are coatings of carbonate (and occasionally silica) and pendants on the undersides of clasts. At the ends of the trench there is a pink (7.5YR7-8/3, dry) Bk horizon beneath this Bkm or Btkm horizon. The Bk horizon is clast-rich ( 2 to 5 percent cobbles and 45 to 55 percent pebbles) and typically sand to loamy sand. It has weak to moderate carbonate cementation (Stage I+ to II+), and common, thin coatings and pendants on undersides of clasts.

The relatively unaltered alluvium (BC and C horizons) in Allomember W2 is clast-rich ( 1 to 2 percent cobbles and 35 to 60 percent pebbles) and typically sand. This pink (7.5YR7-8/3, dry) alluvium has Stage I+ to II- carbonate cementation. Ooliths (globules) are present, but significantly less abundant than in W1. Thin paleocarbonate coatings are common on sides of clasts. The alluvium varies from soft to hard depending upon cementation.

Allomember W2 is predominantly structureless, except where very faint relict bedding occurs in some BCk horizons. Otherwise, the unit is bedded, moderately to poorly sorted, and predominantly gravel and sand. There is evidence of channeling, with many shallow scours indicative of less-confined flow. 


\section{ALLOFORMATION X}

This unit occurs in the western end of the trench (between stations $0+00$ and $1+35$ ) and the eastern part of the trench (between stations $1+80$ and 2+60). A thickness of 0.3 to $5 \mathrm{ft}(0.1$ to $1.5 \mathrm{~m}$ ) is exposed. This unit directly overlies Alloformation $\mathrm{W}$ or has the trench floor as its lower boundary. Alloformation Y overlies the unit throughout the trench. This upper boundary is abrupt or clear, and wavy throughout. Two members were mapped in the field. Because of limited occurrence of one unit, they are combined here for purposes of description.

The upper boundary of Alloformation $\mathrm{X}$ is characterized by a paleosol developed in pebbly ( 30 to 45 percent pebbles), matrix-supported alluvium. This truncated soil is typically loamy sand to sandy loam and dominated by a pink to pinkish-white (5-7.5YR7-8/4-2, dry), carbonatecemented Bkm horizon (Stage III or III+). Cementation is continuous and strong with many moderately thick carbonate-cemented pendants on undersides of clasts. The upper contact is characterized by a discontinuous 0.08 -in $(2-\mathrm{mm})$ carbonate lamina cap and 0.04 -in $(1-\mathrm{mm})$ lamina recurring along major lateral fractures throughout the horizon.

Beneath the Bkm horizon, there are pink to pinkish-white (5-7.5YR7-8/2-4, dry) Bk horizons that extend throughout the length of the trench. These sand to sandy-loam horizons are clast-rich ( 1 to 5 percent cobbles and 25 to 50 percent pebbles). Carbonate cementation (Stage I to II-) is weak, with thin pendants on undersides of clasts.

A Btk horizon overlies the Bkm horizon in the western part of the trench. This pink (7.5YR67/3-4, dry), loamy-sand to sandy-loam Btk horizon has Stage III carbonate-cementation that appears to have undergone some postdepositional degradation. Consequently, despite its continuity, the cementation varies from being weak to strong. There are many thin to moderately thick carbonate- and silica-cemented pendants on undersides of clasts.

The relatively unaltered alluvium ( $\mathrm{BC}$ and $\mathrm{C}$ horizons) in Alloformation $\mathrm{X}$ is clast-rich ( 1 to 5 percent cobbles and 45 to 65 percent pebbles) and matrix- to clast-supported. This pink (7.5YR7/3) to light brown (7.5YR6/3 and 10YR8-6/4, dry) sandy alluvium has Stage I- to I+ accumulation of secondary carbonate. Thin paleocarbonate coatings are common on sides of clasts. The deposit is soft to hard depending on the degree of cementation.

The alluvium in the upper part of unit $\mathrm{X}$ is predominantly structureless where pedogenesis has effectively obliterated bedding. Much of the unit is bedded, moderately to poorly sorted, and dominated by gravel and sand. Channels are abundant, with many shallow scours indicative of less-confined flow. At the base of the unit, the sediment is bedded and moderately to well sorted with coarse gravel and cobbles dominant. There are abundant channels with many shallow scours indicating less-confined flow. 


\section{ALLOFORMATION Y}

This alloformation, which is 1 to $10 \mathrm{ft}(0.3$ to $3 \mathrm{~m})$ thick, is the uppermost unit throughout most of the trench (between stations $0+65$ and 2+60). The western end of the trench (between stations $0+00$ and $0+65$ ) is overlain by Alloformation $\mathrm{Z}$.

Where Alloformation $\mathrm{Y}$ is at the surface, the upper boundary consists of a lateral series of ground soils developed in alluvium, eolian sand, or both (between stations 0+65 and 2+60). Typically, the eolian sand is 5 to $10 \mathrm{in}$. (13 to $25 \mathrm{~cm})$ thick. The upper $4 \mathrm{in} .(10 \mathrm{~cm})$ of the ground soils are a brown (10YR5-7/3-4) sandy-loam A horizon. Where the eolian sand is relatively thick, and surface characteristics indicate a prolonged period of landscape stability, there is a light brown, sandy-loam (7.5YR6/4, dry) Btk horizon beneath this A horizon. Here the accumulation of secondary carbonate and silica is limited to a few thin coatings on undersides of clasts (Stage I-); thin paleocarbonate coatings are present on the sides of some clasts. There are one or more Bk horizons developed in the alluvium. These horizons are typically light brown (10YR6/3-4, dry) or pink (7.5YR7/3-4, dry) and sandy loam, with 1 to 5 percent cobbles and 5 to 50 percent pebbles. The small amount of secondary carbonate present occurs mostly as soft carbonate masses, and thin coatings and pendants on undersides of clasts (Stage I- to I).

The relatively unaltered alluvium (BC and $\mathrm{C}$ horizons) of Allomember $\mathrm{Y}$ is clast-rich (up to 2 percent cobbles, and 5 to 60 percent pebbles), matrix- or clast-supported, and typically sand to loamy sand. The color of this alluvium varies from pink ( $7.5 \mathrm{YR} 7 / 3$, dry) to light brown (7.5YR6/4 and 10YR7-6/3-4, dry) to reddish-yellow (7.5YR7/6, dry) depending on the accumulation of secondary carbonate (Stage I- to I). Thin to moderately thick paleocarbonate coatings are common on sides of clasts. The alluvium is soft and loose.

The upper part of Alloformation $\mathrm{Y}$ is predominantly structureless where pedogenesis has effectively obliterated bedding. However, most of the unit is bedded. The sediment is moderately to poorly sorted, with gravel and sand dominant. Channels are abundant, with many shallow scours indicative of less confined flow. The base of the unit has more bedding (channeling is prominent with many shallow scours indicative of less-confined flow) and the sediment is moderately to well sorted, with coarse gravel and small cobbles common.

\section{ALLOFORMATION Z}

This formation is the youngest unit in the section and occurs at the top and westernmost end of Trench ST02 (between stations $0+00$ and $0+65$ ). It is underlain by Alloformation Y. This discontinuous unit has a maximum thickness of about $8 \mathrm{in.}(20 \mathrm{~cm})$. The lower boundary is abrupt and wavy.

Two members were recognized in the field: Allomember $\mathrm{Zl}$ is associated with constructional surfaces interpreted to be Middle and Late Holocene; Allomember Z2 is associated with Late Halocene (historic) constructional surfaces. Due to the thinness of these units, they are described together. The ground soils associated with these two members are developed in a clast-rich (3 percent cobbles, and 5 to 35 percent pebbles), matrix-supported alluvium. Soil development is limited to a pale brown (10YR6/3, dry) to light yellowish-brown (10YR6/4, dry), sand to loamy sand A horizon having no accumulation of secondary carbonate. 
The unaltered alluvium ( $\mathrm{C}$ horizon) of Allomember $\mathrm{Z}$ is clast-rich (approximately 40 percent pebbles). It is light gray (10YR7/2, dry) and sand or loamy sand. There is little secondary carbonate accumulation; thin paleocarbonate coatings are common on sides of clasts. The alluvium is soft and loose. Faint relict bedding is present, particularly in the deeper channels. The sediment is moderately to poorly sorted gravel and sand with many shallow scours indicative of less-confined flow.

\subsubsection{Trench ST03}

\section{ALLOFORMATION L}

This unit is present only at the bottom and ends of Trench ST03 (between stations $0+35$ and $0+85$, and stations $2+25$ and $2+80)$. It has a maximum thickness of approximately $1 \mathrm{ft}(0.3 \mathrm{~m})$. The trench floor serves as its lower boundary and Alloformation $\mathrm{M}$ as its upper boundary. The upper contact is abrupt and wavy.

The upper boundary of Alloformation L is marked by a paleosol developed in pebbly (20 to 30 percent), matrix-supported alluvium. This truncated soil is characterized by pink (5YR7/3, dry) and brown (5YR6/4, dry) Btk and Bk horizons, having little field evidence of secondary carbonate (Stage I or I-). Accumulation is limited to a few thin coatings on undersides of clasts and carbonate filaments in the matrix. Textures vary from loam to loamy sand depending on the soil horizon.

\section{ALLOFORMATION M}

Alloformation $M$ extends nearly from one end of the trench to the other; it is only missing from the eastern end of the trench (between stations $0+00$ and $0+40)$. The unit is about 1 to $2 \mathrm{ft}(0.3$ to $0.6 \mathrm{~m}$ ) thick. This unit directly overlies Alloformation L where present, or has the trench floor as its lower boundary. Allomember N1 overlies the unit throughout the trench. The upper boundary is abrupt or clear and wavy.

The upper boundary of Alloformation $\mathrm{M}$ is characterized by a paleosol developed in clast-rich (approximately 25 percent pebbles), matrix-supported alluvium. This light brown (7.5YR6/4, dry) to pink (7.5YR7/3, dry) truncated paleosol is sandy loam. The Btk and Bk horizons, where present, show little field evidence of secondary carbonate accumulation (Stage I-), few to common carbonate filaments, and thin coatings on undersides of clasts. There is no cementation.

The relatively unaltered alluvium (BC and $\mathrm{C}$ horizons) in this alloformation is clast-rich (65 percent pebbles) and clast-supported. This pink (7.5YR7/3, dry) to light brown (7.5YR6/4, dry) alluvium is typically sand to sandy loam with Stage I to II- carbonate accumulation. Only a few, thin paleocarbonate coatings occur on sides of clasts. The deposit is loose to slightly hard, depending on the degree of carbonate cementation.

The unit is predominantly structureless, moderately to poorly sorted, and with gravel and sand dominant. The lower part of the unit is similar, but bedded. Here channels are abundant, with many shallow scours indicating less-confined flow. 


\section{ALLOFORMATION N}

\section{Allomember N1}

Allomember N1 extends the entire length of the trench and varies from about 1 to $3 \mathrm{ft}(0.3$ to $1 \mathrm{~m}$ ) thick. This unit directly overlies Alloformation M, where present, or has the trench floor as its lower boundary. Allomember N2 overlies the unit throughout the trench. The upper boundary is abrupt or clear and wavy to irregular, which is the result of incision by numerous stream channels in the base of the overlying N2 unit.

The upper boundary of Allomember N1 is very distinctive. The contact is defined by a paleosol having an eolian mantle (with less than 10 percent pebbles) that overlies clast-rich ( 20 percent pebbles), matrix-supported alluvium. The uppermost soil horizon, a BA horizon in the eolian sediment, is brown (5-10YR6/4, dry), silt loam to very fine sandy loam, and contains common very fine roots, tubules, and vesicular pores. Beneath these horizons are $\mathrm{Bw}$ or Bk horizons (with minimal secondary carbonate accumulation [Stage I-]). These horizons, although lighter brown (7.5YR6/4) and somewhat coarser in texture (sandy loam), also contain ample evidence of previous root activity. Evidence of limited clay accumulation is present in some B horizons.

The relatively unaltered alluvium (BC horizon) is clast-rich ( 20 percent pebbles) and matrixsupported. This light reddish-brown (5YR6/3, dry) alluvium is typically loamy sand. The accumulation of secondary carbonate is limited to few filaments and the underside of clasts (Stage I-). The alluvium is slightly hard.

Allomember N1 is predominantly structureless, moderately to poorly sorted, and contains predominantly gravel and sand. The lower part of the unit is similar, but bedded. Channels are abundant, with many shallow scours indicative of less-confined flow.

Four soil samples were taken from the eolian sediment for optically stimulated luminescence (OSL) analysis (Appendix E). The samples were divided into two groups: two samples from station $2+30$ and two more samples at station $2+40$. Assuming a mean postdepositional volumetric water content of approximately 20 percent results in an age of 14,000 yrs for sample 4-3 and 14,500 yrs for the other three (Appendix E). This suggests that the eolian sediment accumulated on a surface that was stable during the Late Pleistocene.

\section{Allomember N2}

Allomember N2 extends the entire length of the trench, and its exposure varies from about 4 to $6 \mathrm{ft}$ ( 1 to $2 \mathrm{~m}$ ). This unit directly overlies Allomember N1. Its natural surface has been disturbed and covered by about $2 \mathrm{ft}(0.6 \mathrm{~m})$ of construction overburden (spoil). This lower boundary is abrupt and wavy.

The upper contact is characterized by a truncated ground soil. The uppermost soil horizon is a pink (7.5YR7/4-3) BA horizon, loam, and contains 5 to 10 percent pebbles. Very fine vesicular pores and root traces are common. Below this horizon, there are several brown (7.5-10YR6/4-3), sandy-loam Bk horizons. The accumulation of secondary carbonate is weak (Stage I-), being limited to thin carbonate coatings on undersides of clasts. The clast content ranges from 5 to 30 percent. 
The relatively unaltered alluvium (BC horizons) below the $\mathrm{Bk}$ horizons varies from practically clast-free ( 1 percent) to clast-supported ( 65 percent pebbles), and from sand to sandy loam. The colors range from pale brown (10YR6/3) to pink (7.5YR7-6/3). The accumulation of secondary carbonate is limited to thin coatings on the undersides of clasts and occasional carbonate filaments and soft masses in the matrix (Stage I-). Thin paleocarbonate coatings are common on sides of clasts. The alluvium is soft and loose.

Very faint to distinct relict bedding is present, with weak medium to coarse, subangular blocky structure where soil development is better. Areas that have undergone little pedogenesis are bedded, moderately to poorly sorted (gravel and sand), and have abundant channeling, with many shallow scours indicative of less-confined flow. The lower portion of the unit is structureless, moderately to well sorted, and predominantly sand, silt and clay. Coarse sand is present in discontinuous lenses.

Small fragments of charcoal were found in a stream channel at station $2+45$. Carbon-14 analysis of these small fragments resulted in an uncorrected age of 12,550 yrs before present (Appendix E). One soil sample was taken adjacent to the charcoal sample location for OSL analysis (Appendix E). The result of this analysis, assuming a mean postdepositional volumetric water content of approximately 20 percent is $12,500 \mathrm{yr}$. A second sample for OSL was taken above these two samples. Assuming a water content of about 20 percent results in an estimated age of 10,500 yrs (Appendix E). This suggests that net aggregation was rapid within the N2 Allomember and that the ground soil is probably Holocene.

\subsection{Fractures}

Allostratigraphic units and fractures were mapped in Trenches ST02 and ST03 and plotted on base maps. Fractures believed to be related to tectonic activity are shown on these maps; however, not all fractures shown are unequivocally tectonic. Fractures that are obviously related to soil structure are not shown on the maps, but are described in the text below. Fractures in both trenches are commonly hairline cracks that sometimes have concentrations of modern roots or secondary carbonate coatings, the latter being less than 0.08 in. $(2 \mathrm{~mm})$ thick. A few fractures are filled with thicker laminar carbonate where they cut older, carbonate-cemented strata. In gravelly deposits, fractures are often expressed as subvertical zones of weak, diffuse carbonate cementation.

The strike of a fracture was measured where expression of the plane was deemed sufficient for reasonable accuracy. Most dips appeared near-vertical. However, the dip of a fracture was usually not measured due to the difficulty of measuring true dip from a vertical exposure. The dip was estimated for a few of the gently dipping fractures. Both trenches were excavated to a depth of $10 \mathrm{ft}(3 \mathrm{~m})$, with a bench on each side at $5 \mathrm{ft}(1.5 \mathrm{~m})$ below the ground surface, resulting in an approximate $3 \mathrm{ft}(1 \mathrm{~m})$ backset of the upper face. This backset made tracing fractures between the lower and upper faces difficult.

All mapped fractures were examined for offset. In both Trenches ST02 and ST03, this process was often complicated because the orientation of paleochannels and fractures is similar to the orientation of the Area 3 fault. Strike-slip offset across any fractures can neither be demonstrated or ruled out in Trenches ST02 or ST03. 


\subsubsection{Trench ST02}

Many fractures were noted in Trench ST02 in older, more indurated strata (Alloformations W and $\mathrm{X}$ ), but no significant vertical offset was observed on any horizon. Most of the fractures are thought to be tectonic. The following evidence supports this conclusion:

1. The abundance of fractures in Trench ST02 relative to trenches dug in nearby unfaulted areas (e.g., Area 5; Snyder et al, 1993);

2. The distribution of these fractures in zones, and especially at the west end of the trench, as opposed to even distribution throughout the trench;

3. The splaying upward of two or three fracture sets near the west end (which is unusual, and probably cannot be related to the growth of roots or any other nontectonic explanation); and

4. A thin filling of calcium carbonate.

The carbonate could have developed since the time that underground nuclear tests were first conducted in Yucca Flat (1962), however, evidence suggests otherwise. The fillings are 0.04 in. $(1 \mathrm{~mm})$ thick and at least $2 \mathrm{ft}(0.6 \mathrm{~m})$ below the surface, with no fracture in the overlying younger deposits to serve as a pathway for carbonate-enriched water.

The orientation of 49 fractures was measured in Trench ST02, with the majority of fractures trending northeast. Nine fractures, clustered between stations $0+60$ and $0+85$, measured strikes between $15^{\circ}$ and $30^{\circ}$, which is $\pm 5^{\circ}$ of the $20^{\circ}$ to $25^{\circ}$ strike expected of the BILBY (U3cn) and CANVASBACK (U3cp) fractures at this location (Plate 2). The BILBY and CANVASBACK fracture orientations are along the general trend of the Area 3 fault.

No fractures were observed in Alloformation Z. Numerous fractures were mapped in Alloformation Y. Most of these fractures continue up from fractures in Allomember X2. In Alloformation Y, the fractures are either uncoated or weakly coated with calcium carbonate, and show preferential growth of modern roots. In general, these fractures trend northeast. No offset was found across any fracture in Alloformation Y.

Numerous nontectonic fractures related to soil ped surfaces are present in the upper soil horizons of Alloformation Y. They represent the faces of coarse prisms. Clearing of the ground surface adjacent to the trench revealed that these fractures intersect each other in a polygonal pattern typical of prismatic structure. These fractures are not shown on the map.

Fractures are more abundant west of station $0+90$, and are much more abundant in Alloformations $\mathrm{X}$ and $\mathrm{W}$ than in the overlying Alloformation $\mathrm{Y}$. Many fractures in Alloformations $\mathrm{X}$ and $\mathrm{W}$ are coated with calcium carbonate. Coatings are typically 0.04 in. $(1 \mathrm{~mm})$ thick. Fractures that cut Alloformation W generally penetrate into Alloformation X, although a few fractures are restricted solely to Alloformation W. Most of the fractures penetrating Alloformation $\mathrm{X}$ are truncated at the contact with Alloformation $\mathrm{Y}$. Alloformations $W$ and $X$ are not exposed between stations $1+35$ and $1+75$; however, elevations of strata on either side of the unexposed area correlate well, suggesting there is no major offset of Alloformations $\mathrm{W}$ and $\mathrm{X}$.

The abundance of fractures in the zone between stations $0+07$ to $0+20$ along the lower face, and changes in the nature and elevation of Allomember W2 across this zone, prompted close 
inspection of the area for fault-related offset. Although facies changed and erosion occurred within Allomember W2, explaining changes in nature and elevation within the unit, individual fractures revealed no offset strata. Allomember W1 is too sporadically exposed to determine whether it has been displaced by faulting. However, it does show strong fractures with laminar calcium carbonate and silica zones in several locations.

\subsubsection{Trench ST03}

The orientation of 71 fractures was measured in Trench ST03, and the majority trend northeast. Approximately half of these fractures are confined to Allomember N2, and generally have measured strikes between $0^{\circ}$ to $25^{\circ}$, which is $\pm 10^{\circ}$ of the $10^{\circ}$ to $15^{\circ}$ strike expected of the BANDICOOT (U3bj) fractures at this location (Emerick, 1963). The orientation of the measured fractures is along the general trend of the Area 3 fault.

Three fractures are particularly significant because they cross the entire stratigraphic section exposed in the trench. Two of these fractures are between stations $1+36$ and $1+39$, possibly merging to become a single fracture along the upper trench face. The third fracture is near $2+46$, oriented approximately $20^{\circ}$, and transects channel deposits. The channel strata act as marker beds where offsets of 0.2 to 0.6 in. $(0.6$ to $1.5 \mathrm{~cm})$ were measured. The third fracture has very little carbonate filling. Modern roots are present and extend almost to the contact with Alloformation M. The fracture can be traced upward to the surface, but any offset of beds above the bench is not discernable. Above bench level, the fracture becomes narrow and indistinct.

Fractures in Alloformation $M$ are clustered between stations $0+50$ and $0+80$. These fractures are too numerous to show individually at map scale. They are spaced about $6 \mathrm{in} .(15 \mathrm{~cm})$ apart, and are distinctly coated with a thin film of calcium carbonate. Orientations of these fractures are difficult to measure, due to poor exposures. Alloformation $\mathrm{M}$ ends abruptly at station $0+45$, an area where numerous fractures are present. A close inspection of this location indicated that Alloformation $\mathrm{M}$ was truncated by channeling.

Between stations $0+40$ and $0+50$, Alloformation $\mathrm{L}$ is highly fractured, and has a highly irregular upper contact, due primarily to channeling. The irregularity of the top precludes interpretation of offset.

Fractures elsewhere in the limited exposures of Alloformation $\mathrm{L}$ are similar to, and continuous with, fractures in Alloformation M, with the exception of numerous nontectonic fractures present in the upper soil horizons of Alloformation M. These fractures represent the faces of coarse prisms. The angular relations of the fractures are in a polygonal pattern, typical of prismatic structure. In addition, local areas in Alloformation M and Allomember $\mathrm{N} 2$ are characterized by large blocks surrounded by carbonate-coated fracture faces. These fractures are related to soil structure and consequently are not shown on the map.

\subsubsection{Conclusions}

The Area 3 fault is a plane of weakness that has undergone strain resulting from stress imposed by natural events, and more recently, by underground nuclear testing. Several fractures near the center of Trench ST03 are thought to be test-induced fractures oriented with the Area 3 fault because of location, orientation, and penetration of the youngest deposits,. Calcium carbonate 
coatings associated with test-induced fractures are weak, and could possibly have formed since 1962, when underground nuclear testing was initiated in Yucca Flat.

In general, fractures in older deposits exposed in Trench ST03 have orientations between $40^{\circ}$ and $60^{\circ}$, much less reflective of the orientation of the Area 3 fault. Conversely, the orientations of fractures in Trench ST02 that pre-date underground nuclear testing in Yucca Flat show a rough correspondence to the orientation of the Area 3 fault.

No major vertical displacement on the Area 3 fault since the Early Holocene, and possibly since the Middle Pleistocene, can be demonstrated by the continuity of alloformations in Trenches ST02 and ST03. The lack of major displacement within this time frame, and minimal vertical extent of minor fractures, suggests that waste disposal operations at the Area 3 RWMS will not be impacted substantively by the Area 3 fault within the regulatory compliance period.

\subsection{SURFICIAL MAPPING}

\subsection{Previous Mapping}

The two groups of researchers that have mapped the surficial deposits of Yucca Flat are Fernald et al, (1968) in the 1960s, and Swadley and Hoover (1990) in the late 1970s and mid-1980s. Although similar, there are significant differences between the two approaches. The map of Fernald and others (1968) first segregates surficial deposits by surficial process and landform (e.g., colluvium or fan alluvium), then by sediment character (e.g., poorly bedded rubble or wellbedded sand), and finally by provenance (e.g., volcanic or clastic rocks). The map unit delineations seem generalized, typically being large with subrounded and smooth boundaries. The line density on this 1:48,000 scale map is low. There is no information on the map regarding how the mapping was done.

Subsequent mapping by Swadley and Hoover (1990) was based on their surficial studies done throughout the NTS and southern Great Basin in the 1970s (Hoover et al, 1981). Their map identifies only alluvial, eolian, and playa deposits. The authors subdivide such sediments into age classes based primarily on topographic character (e.g., microtopography and macrotopography), drainage pattern, inset relations, soils, and desert pavement, with depositional environment and lithology as secondary criteria. The map unit delineations are more numerous, subangular, and denser than Fernald and others (1968), even though both maps were published at a scale of 1:48,000. Swadley and Hoover state that their published map was compiled from 1:24,000-scale aerial photographs and supported by very limited field observations.

\subsection{Current Mapping}

A geomorphic surface map was made of Yucca Flat (Plate 3) that utilizes the recent geomorphology and soil characterization work done in adjacent northern Frenchman Flat. However, rather than undertaking a substantial mapping project, the approach was to adopt the map unit boundaries (line work) of Swadley and Hoover (1990) and relabel these map units with map unit designations like those in northern Frenchman Flat (Huckins-Gang et al, 1995a,b,c; Snyder et al, 1995a,b,c,d). 


\subsubsection{Sample Design}

The sample design is based on guidelines set forth by Forbes and others (1987), which state that transects should have at least 10 transect points, and each point should be located greater than $0.013 \mathrm{mi}(0.20 \mathrm{~km})$ apart. To evaluate map units effectively, transects should be aligned perpendicular or oblique to the predominant drainage pattern.

A $0.20 \mathrm{mi}(0.30 \mathrm{~km})$ interval was selected as the distance between transect points. A prospective transect had to be at least $1.8 \mathrm{mi}(2.8 \mathrm{~km})$ in length to encompass 10 points spaced at a $0.20-\mathrm{mi}$ $(0.30-\mathrm{km})$ interval. Secondary roads are abundant throughout Yucca Flat. Aerial photographs and USGS topographic maps were examined to identify all road segments (transects) of appropriate length and orientation throughout Yucca Flat. Sinuous roads were avoided because of the positional error that might result from field measurement and transcription of point locations onto the base map. A total of 30 transects were randomly located and identified on the two base field photographs.

The alluvial fans within Area 3 and the southern part of Area 7 were of greatest interest because of proximity to the Area 3 RWMS, and received a more intensive analysis. To ensure statistical reliability of the observations within this detailed study area (Barth et al, 1989), an average of approximately 20 transect points was desired for each of the three alluvial fan map units (QTa, Qap, and Qah) delineated on the Swadley and Hoover (1990) base map. From the 10 prospective transects located within the area, six primary transects and four alternates were randomly selected (yielding 60 transect points). If any of the six primary transects were undriveable or otherwise unsuitable, an alternate transect was used.

Additional transects were selected subjectively to be physiographically representative of the different terrains and geomorphic surfaces outside Area 3 and southern Area 7. Of the 20 prospective transects outside the detailed study area, 6 were identified as likely to yield an additional 60 transect points throughout Yucca Flat. An additional nine plots not associated with any of the transects in Yucca Flat were done in conjunction with existing soil profile excavations to compare surface information with more detailed soil data.

\subsubsection{Mapping Uncertainty}

Two distinct types of mapping uncertainty are inherent in a study of this type. Cartographic error is uncertainty inherent in the cartographic plotting of map unit delineations onto a base map. Positional error is the uncertainty associated with correctly identifying a point on the landscape and transcribing it to the base map (National Institute of Standards and Technology [NIST], 1992).

Cartographic error can be defined as the ground distance represented by the width of the line used to inscribe the delineations on the base map (Forbes et al, 1987). Cartographic error is entirely scale-dependent and inversely proportional to the map scale, meaning error increases as map scale decreases. A point or line on a map cannot be described with more accuracy than its own physical representation will allow, so cartographic error is fixed and unavoidable in any mapping exercise. For this study, cartographic error was defined by the 0.01 -in $(0.25-\mathrm{mm})$ line width of the map unit delineations on Swadley and Hoover's (1990) base map. This line width corresponds to $40 \mathrm{ft}(12 \mathrm{~m})$ of ground distance. Hence, $40 \mathrm{ft}(12 \mathrm{~m})$ was accepted as the minimum error (at a 1:48,000 scale) and was used as the minimum offset distance from all roads for the transects, and the radius of the evaluation plot surrounding the transect point. 
Positional error is scale-dependent, but also varies with proximity to topographic control points, field measurement techniques, and distortion of the photographic base. To evaluate positional error, it was necessary to define the threshold at which observations at a sample point might differ in character from the named map unit, but still not reflect on the accuracy of the delineation. The frequency of observations that fall on or adjacent to a map unit boundary increases as line density on the map increases. Inclusions are areas on the landscape too small to be delineated or are otherwise unsuitable for cartographic presentation at the published scale. The minimum length of a map unit delineation on the base map of Swadley and Hoover (1990) was determined to be approximately $0.08 \mathrm{in}$. $(2 \mathrm{~mm})$, which corresponds to approximately $300 \mathrm{ft}$ $(90 \mathrm{~m})$ of ground distance. A value of $0.08 \mathrm{in} .(2 \mathrm{~mm})$ was assumed to be a conservative, but reasonable, estimate of the maximum expected positional error.

\subsubsection{Transect Procedure}

The map and photographic coverage used for transect work was:

- 1:48,000 surficial deposits map of Yucca Flat (Swadley and Hoover, 1990);

- Photocopies of original 1:24,000 surficial deposits mapping sheets used to compile the 1:48,000 map of Swadley and Hoover (1990);

- 1:9,950 color, 1:20,000 color, and 1:24,000 black-and-white aerial photographs;

- $1: 24,000$ USGS topographic maps.

In addition, map unit descriptions of surficial deposits in Yucca Flat (Swadley and Hoover, 1990) and geomorphic surfaces (Huckins-Gang et al, 1995a,b,c; Snyder et al, 1995a,b,c,d) in northern Frenchman Flat (Tables 5-1 and 5-2) were studied and taken to the field.

The steps used to locate each transect point and corresponding evaluation plot were:

1. Select a starting location on a road segment (transect) at, or a measured distance from, a ground control point. The control point was a (point) feature clearly identifiable in the field, on an aerial photograph, and on a topographic map.

2. At the starting location, select an upslope or downslope direction perpendicular to the road. Typically, the upslope direction was selected to avoid possible effects of runoff from the road. Pace a distance of $40 \mathrm{ft}(12 \mathrm{~m})$ from the edge of the road to establish the transect point (the evaluation plot center). If the plot was found unsuitable (e.g., human surface disturbance or radioactive contamination), additional 40-ft (12-m) intervals were paced off. If an acceptable area could not be located after four 40-ft (12-m) intervals, then the attempt to establish that transect point was abandoned. All established transect points were marked on the aerial photograph.

3. A transect point description form (Figure 5-1) was completed for the most extensive component landform within the $40-\mathrm{ft}(12-\mathrm{m})$ radius plot. To obtain data for the soil mantle, a small hole was excavated to a depth of 10 to 12 in. $(25$ to $30 \mathrm{~cm}$ ).

4. A vehicle odometer was used to measure $0.20 \mathrm{mi}(0.31 \mathrm{~km})$ to the next transect point, except for Transect 30 where an interval of $0.40 \mathrm{mi}(0.62 \mathrm{~km})$ was used.

Landscape and soil characteristics were recorded on a transect point description form (Figure 3). Surface pavement was separated into four classes based on the percentage of surface area covered by pavement. Surface pan fragments (i.e., carbonate- or silica-rich platelets exhumed 


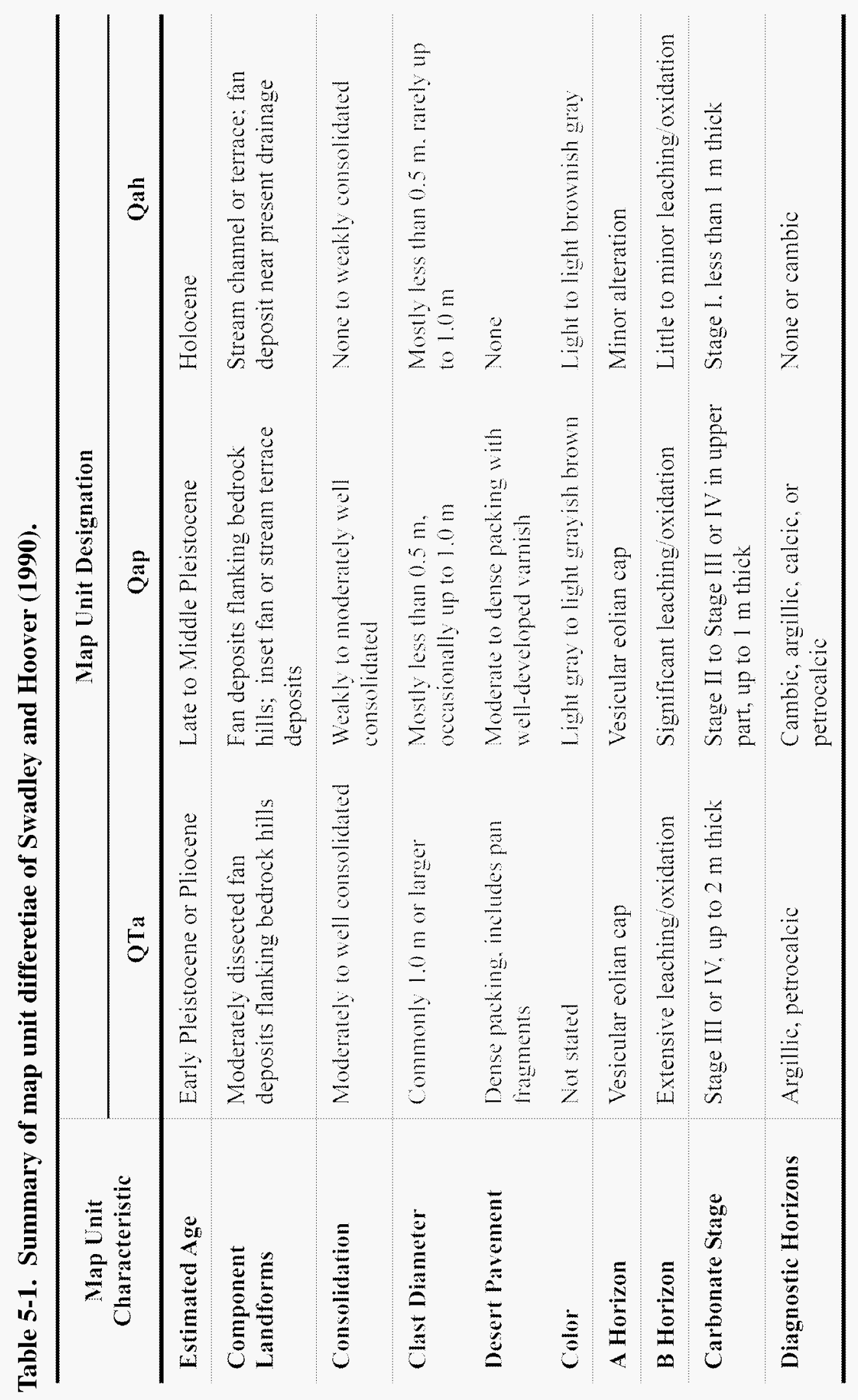




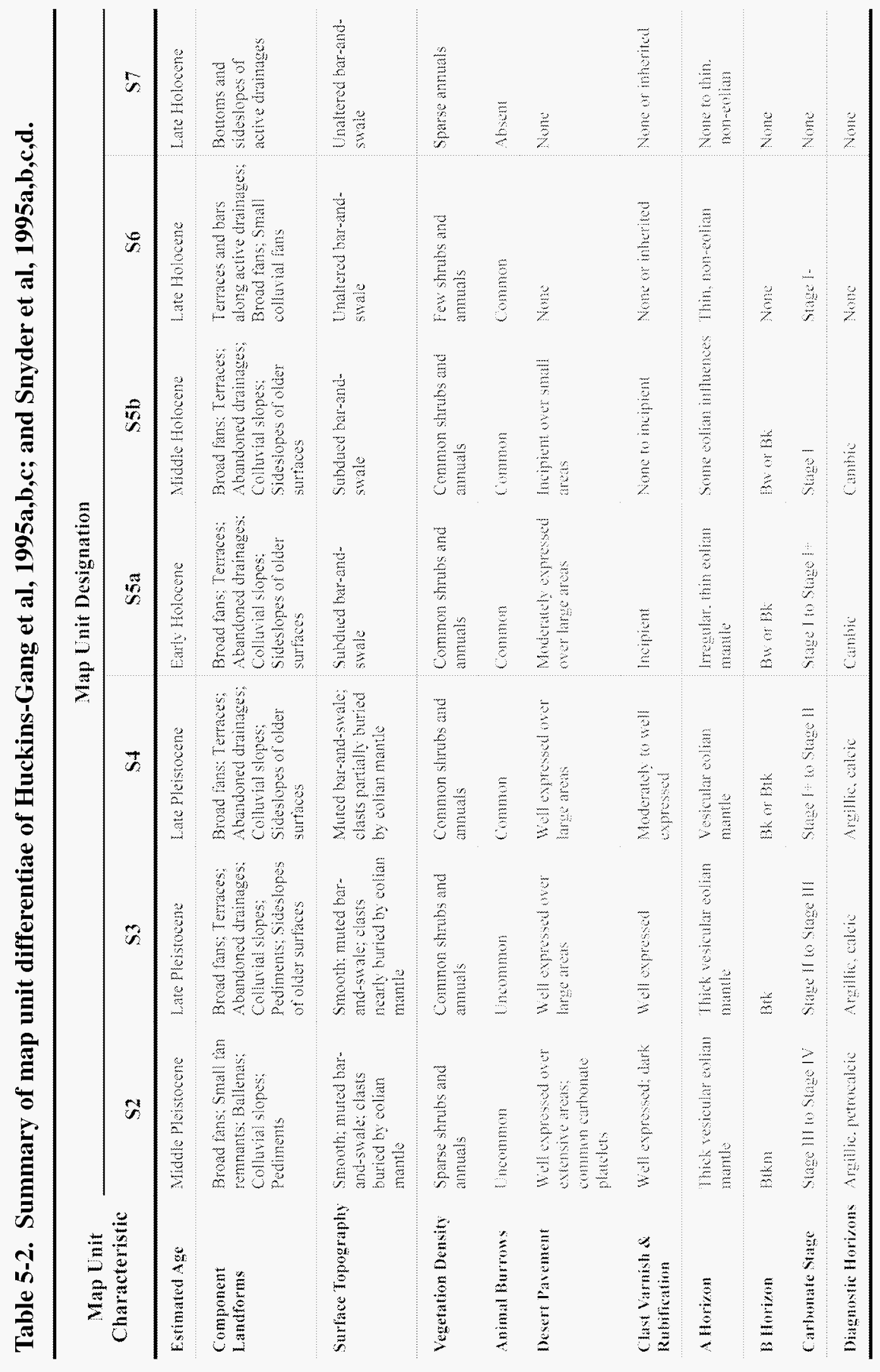


Description of Transect

Point

Date:

Distance from road to the transect point (center of evaluation plot): feet

List deviations in protocol to establish evaluation plot:

On the component landform within the plot, evaluate the following:

Identify key uninherited surficial characteristics used to assign surface designation:

$\begin{array}{llllll}\text { Perennial Vegetation: } & <5 \% & 5-25 \% & 25-50 \% & >50 \% & \\ \text { Microbiotic Crust: } & \text { None } & <5 \% & 5-25 \% & 25-50 \% & >50 \% \\ \text { Firmness of Surface: } & \text { Loose } & \text { Soft } & \text { Somewhat Firm } & \text { Very Fin } \\ \text { Surface Pavement: } & \text { None } & <25 \% & 25-75 \% & >75 \% & \\ \text { Bar-and-Swale Topography: } & \text { Unaltered } & \text { Subdued } & \text { Muted } & \text { Smoothed } & \\ \text { Pan Fragments: } & \text { None } & <5 \% & 5-25 \% & 25-50 \% & >50 \% \\ \text { Varnish: } & \text { None } & <50 \% \text { (light) } & >50 \% \text { (dark) } \\ \text { Rubified Clasts: } & \text { None } & <25 \% & 25-50 \% & >50 \% & \end{array}$

Eolian Cap: $\mathrm{cm}$ thick

Soil Color:

A horizon

B horizon

Soil Structure: A horizon B horizon

Argillic Horizon:

Absent

Present in Cap

Present in Alluvium

Secondary Carbonate: Stage I

Stage II

Stage III

Stage IV

Slope Gradient (long-axis): $\%$

Type of Surface: Constructional Erosional Undetermined

Other:

Does component landform fit the map unit description on base map? Yes No

If not, is minimum length of component landform less than 300 feet? Yes No

$\begin{array}{lllllllll}\text { What surface would we assign to component landform? } & 2 & 3 & 4 & 5 \mathrm{a} & 5 \mathrm{~b} & 6 & 7\end{array}$ List \% composition of surfaces within the evaluation plot:

Figure 5-1. Transect point description form. 
from an underlying hardpan) were grouped into five classes based on the percentage of surface fragments they comprised, and rubification was characterized using four classes based on the percentage of rubified surface clasts present. Desert varnish was separated into three categories based on visual estimates of development. Microbiotic crusts (cryptogams) and perennial vegetation were separated into classes based on the percentage of surface area covered. Surface firmness and bar-and-swale topography were rated qualitatively.

The slope gradient was measured with an Abney level. Thickness of an eolian cap (mantle) was measured if present. Color and structural characteristics of the A or B horizons were recorded (Soil Survey Division Staff, 1993) and development of argillic or shallow carbonate-rich horizons was described. Any other characteristics thought to be relevant, such as clast lithology of the alluvium were also recorded. It was determined whether the transect point was located on a landform with a long axis less than $300 \mathrm{ft}(90 \mathrm{~m})$. A geomorphic surface map unit designation from northern Frenchman Flat was assigned to the dominant surface of the landform. Finally, the proportion of different surfaces within the evaluation plot was estimated.

\subsubsection{Data Compilation}

Twelve transects, yielding 119 transect points (evaluation plots), were selected from 30 prospective transects. An additional nine evaluation plots were recorded. The location of each transect point was transcribed from the field photographic base to the 1:48,000 map of Swadley and Hoover (1990) with the aid of 1:24,000 USGS topographic maps. Next, each transect point was assigned to the name of the map unit that it fell within. The transect points were tabulated, resulting in a preliminary correlation chart similar to Table 5-3. Despite some dispersion of the data, this preliminary correlation chart contained three groups: QTa deposits associated with S2 and S3 surfaces; Qap deposits associated with S3, S4, and S5a surfaces; and Qah deposits associated with S5a, S5b, S6, and S7 surfaces. Transect points outside of these groups were then analyzed to determine if they were map unit inclusions. There was a more appropriate Swadley and Hoover (1990) designation based on considerations of position error; or they differed grossly from the Swadley and Hoover (1990) unit designation. Criteria for this analysis were:

1. Landform described in the field was shorter than $300 \mathrm{ft}(90 \mathrm{~m})$. The transect point retained the original Swadley and Hoover (1990) map unit designation and was called an inclusion.

2. Landform described in the field was longer than $300 \mathrm{ft}(90 \mathrm{~m})$, the transect point was $0.08 \mathrm{in} .(2 \mathrm{~mm})$ or less from a map unit boundary (the estimate for positional error), and the field description matched an adjoining Swadley and Hoover (1990) map unit. The transect point was reassigned the matching map unit designation and was called a boundary correlation.

3. Landform described in the field was longer than $300 \mathrm{ft}(90 \mathrm{~m})$, the transect point was $0.08 \mathrm{in} .(2 \mathrm{~mm})$ or less from a map unit boundary (the estimate for positional error), and the field description did not match an adjoining Swadley and Hoover (1990) map unit. The transect point retained the original map unit designation and was called an outlier.

4. Landform described in the field was longer than $300 \mathrm{ft}(90 \mathrm{~m})$, the transect point was greater than 0.08 in. ( $2 \mathrm{~mm}$ ) from a map unit boundary (the estimate for positional error), and the field description did not match the surrounding Swadley and Hoover (1990) map unit. The transect point retained the original map unit designation and was called an outlier. 


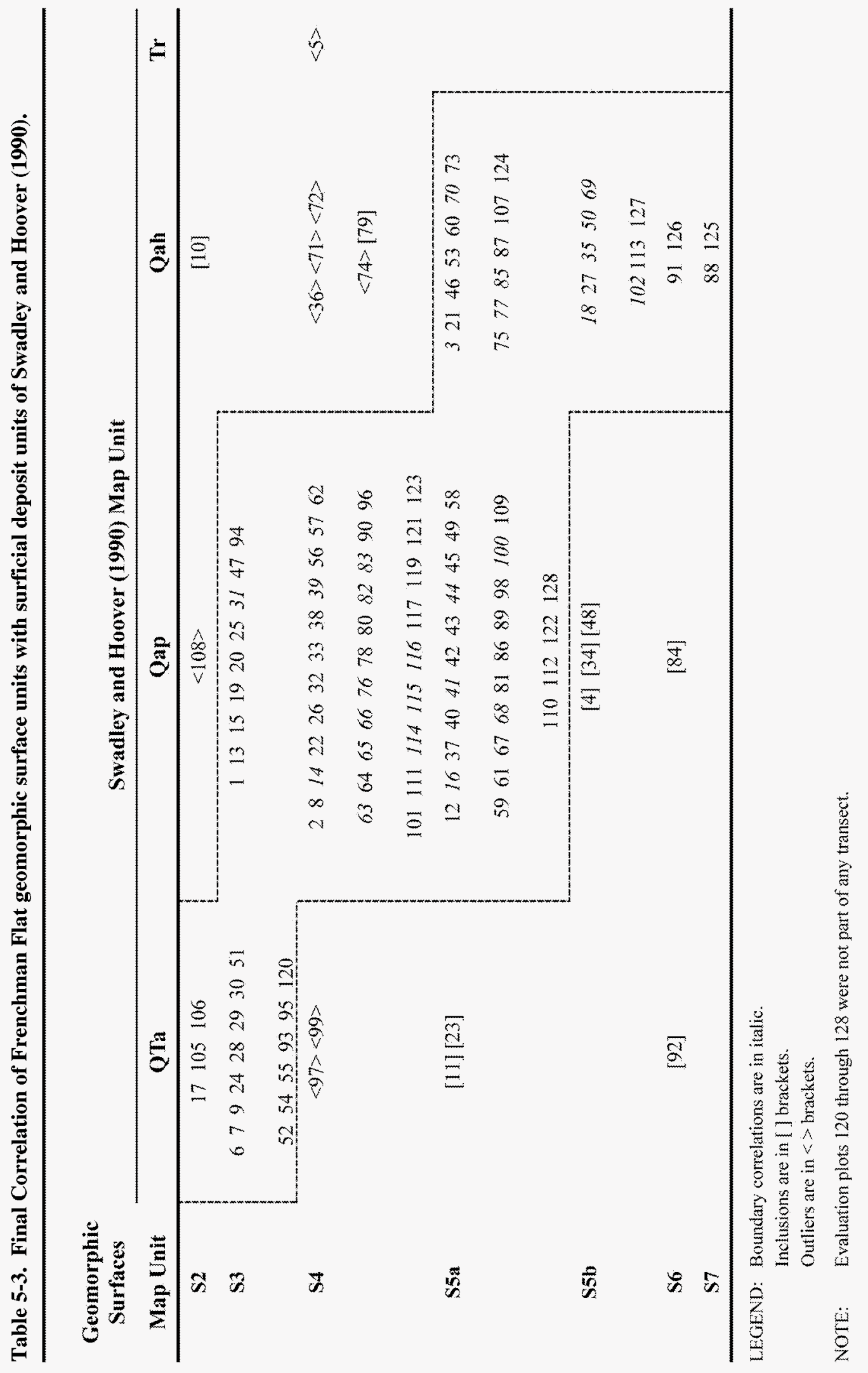


This analysis resulted in a final correlation chart (Table 5-3). The chart shows a consistent relationship between the geomorphic surfaces as mapped in northern Frenchman Flat and the surficial deposits delineated by Swadley and Hoover (1990): S2 and S3 surfaces fit the QTa delineations; S3, S4, and S5a surfaces fit the Qap delineations; and S5a, S5b, S6, and S7 surfaces fit the Qah delineations. These relationships were then used to relabel the map unit boundaries (line work) of Swadley and Hoover (1990). The result was Plate 3.

Table 5-3 also shows that two geomorphic surfaces are split between surficial deposit units: S3 between QTa and Qap, and S5a between Qap and Qah. A review of the transect point description sheets found no field characteristics that would result in consistently partitioning either S3 into QTa and Qap, or S5a into Qap and Qah. However, it is possible that Swadley and Hoover (1990) had some difficulty in consistently segregating surfaces of similar classes (age) that have different tone or texture on a photograph. On the map, Swadley and Hoover (1990) state that "[t]his map was prepared from aerial photographs and from very limited field observations." Any such errors of photographic interpretation had a small probability of being corrected because of limited ground truthing.

Table 5-4 shows that 85 percent of the transect points were either direct or boundary correlations (the latter considers precision error). Eight percent of the transect points were classified as inclusions, meaning these points represented areas smaller than the minimum delineation size of the 1:48,000 map. The inclusions were evenly distributed among the transects. Correlations and inclusions represented 93 percent of the observations, leaving just 7 percent of the transect points as outliers. Of these outliers, two were closely spaced in one transect, and three were closely spaced or consecutive in a second transect (Table 5-3). Seven of the eight outliers involved the classification of S4 surfaces (Table 5-3). The data indicate that the map of Swadley and Hoover (1990) does not, on occasion, segregate Qap map units (where all other S4 observations occur) from QTa or Qah map units; and the S4 surfaces are not uncommon inclusions in S2, S3 map units, and S5, S6, S7 map units. This fact does not reduce the accuracy of adopting the line work of the Swadley and Hoover (1990) map. 
Table 5-4. Transect point and evaluation plot tally.

\begin{tabular}{|c|c|c|c|c|}
\hline Transect & Correlations & $\begin{array}{c}\text { Boundary } \\
\text { Correlations }\end{array}$ & Inclusions & Outliers \\
\hline $\mathbf{2}$ & 6 & 1 & 2 & 1 \\
\hline $\mathbf{3}$ & 7 & 2 & 1 & - \\
\hline $\mathbf{4}$ & 8 & - & 1 & 1 \\
\hline $\mathbf{5}$ & 6 & 3 & 1 & - \\
\hline $\mathbf{8}$ & 6 & 3 & 1 & - \\
\hline $\mathbf{1 0}$ & 10 & - & - & - \\
\hline $\mathbf{1 2}$ & 4 & 6 & - & - \\
\hline $\mathbf{1 6}$ & 4 & 2 & 1 & 2 \\
\hline $\mathbf{2 1}$ & 6 & 3 & 1 & 1 \\
\hline $\mathbf{2 3}$ & 6 & 1 & - & - \\
\hline $\mathbf{2 9}$ & 8 & 1 & - & - \\
\hline $\mathbf{3 0}$ & 6 & 3 & 9 & - \\
\hline Total & 77 & 25 & - & $7 \%$ \\
\hline Proportion & $64 \%$ & $21 \%$ & - & - \\
\hline
\end{tabular}




\subsection{PEDOLOGY}

Description and analysis of soils in trenches and across the landscape of Yucca Flat were integral to understanding the surficial geology in the vicinity of the Area 3 RWMS. Of three soil trenches dug (ST01, ST02 and ST03), two ST02 and ST03 (Plate 2, Appendix B), were excavated along the trace of the Area 3 Fault to search for subsurface evidence of faulting (Section 4.0). Numerous small excavations were described (Soil Profiles EX01-P01 through EX09-P01, Appendix C) to help develop a geomorphic surface map of Yucca Flat (Section 5.0, Plate 3)

\subsection{Profile Descriptions and Sample Analysis}

Soil profile descriptions and characterization data were integral in establishing the allostratigraphy in the two soil trenches (Section 4.0). Typically, identification of the bounding discontinuity between allostratigraphic units was based on recognition and correlation of ground soils or buried (truncated) paleosols. Field and laboratory analyses were useful for segregating different allostratigraphic units and different geomorphic surfaces. The principal discriminators were soil structure and consistence, secondary carbonate accumulation, and clay accumulation. Twenty-four soil profiles were described according to protocols of the National Cooperative Soil Survey (Soil Survey Division Staff [1993,1994]). The detailed descriptions are in Appendix C. Eighty-five samples from 12 soil profiles were collected for physical and chemical analyses (Appendix D).

\subsubsection{Soil Structure and Consistence}

A key criterion used to identify the solum (A and B horizon) of a soil is obliteration of all or much of the original geologic structure, in this case, fine stratification in alluvium (Soil Survey Division Staff, 1993). However, most of the alluvium observed in exposures constituting the $\mathrm{C}$ horizon of a soil had bedding that was readily discernible, with very coarse to medium sand grains [ $(0.08$ to 0.02 in. ( 2 to $0.05 \mathrm{~mm}$ ) in diameter] recognizable to the unaided eye. In pedologic terms, this is a single grained (structureless) condition.. The sediment typically was loose with limited cementation by calcium carbonate and silica.

Overlying many $\mathrm{C}$ horizons are $\mathrm{BC}$ horizons where the bedding has been partially obliterated, but evidence of structure is absent. This structure is termed massive (structureless). Field evidence indicates that such massive horizons are the consequence of physical reorganization primarily by roots, insects, and some chemical transformations initiated by percolating water. In conjunction with the physical reorganization, respiration by plant roots may alter the chemical environment, producing a zone of chemical weathering around the root.

In the older allostratigraphic units in Yucca Flat, there are soils with B horizons that have better, albeit weak, structural development than the $\mathrm{BC}$ horizons. Here, pedogenesis (soil formation) has progressed to the point where the original bedding has been obliterated and the soil particles have reorganized into three-dimensional units (peds) separated by surfaces of weakness. Typically, the structure is medium to coarse subangular blocky. 


\subsubsection{Secondary Carbonate and Silica}

Another key criterion used to identify the solum (A and B horizons) of a soil is the transformation, accumulation, or loss of secondary carbonate and silica (Soil Survey Division Staff, 1993). Soils developed under arid and semiarid climates often have accumulations of secondary calcium carbonate, silica, or both. The profiles described in Appendix $\mathrm{C}$ have such accumulations. The general pattern of carbonate accumulation follows that first outlined by Gile et al, (1966) for arid soils in southern New Mexico; the notation (stage) used in this study to describe this pattern follows Birkeland (1984).

In general, the sediments that retain sedimentary bedding ( $\mathrm{C}$ horizons) have very little, if any, secondary carbonate present (no carbonate stage). The small quantity of carbonate present occurs as very thin, discontinuous coatings on the bottom of clasts (Stage I). In a few $\mathrm{C}$ horizons, some pebbles are weakly cemented to the bottom of larger clasts (Stage I+ and designated $\mathrm{Ck}$ horizons). In $\mathrm{BC}$ horizons, carbonate usually coats the bottoms of quartzite and carbonate clasts and the entirety of pyroclastic volcanics (Stage I). Areas where cemented pebbles and sand form pendants on bottoms of clasts (Stage I+ and designated BCk horizons) are common. In B horizons, carbonate usually coats the entirety of all clasts regardless of lithology (Stage I) and, again, there are areas where cemented pebbles and sand form pendants on bottoms of clasts (Stage I+ and designated Bk horizons). Transitional BA horizons may or may not show evidence of carbonate accumulation.

Related to the accumulation of secondary carbonate is the removal or etching of paleocarbonate coatings from clasts. This paleocarbonate is carbonate that accumulated on the clasts prior to their deposition at their present locale. It may have originated as pedogenic carbonate in another soil upslope that was subsequently eroded or as carbonate from gully-bed cementation. Either way, the exotic character of the paleocarbonate is recognizable due to the random juxtaposition of the coatings on clasts: some clasts are entirely coated, whereas adjacent clasts are uncoated, and still others have coatings only on the sides or tops. Removal or etching of the paleocarbonate provides further clues to the presence of pedogenic horizons. The general pattern of paleocarbonate occurrence is:

- In C horizons (unaltered sediments), coatings are random on adjacent clasts;

- In Ck horizons, coatings have been only partially removed from the tops and sides of clasts;

- In BC horizons, coatings have been removed from the tops and often the sides of all but the largest clasts; and

- In B horizons, coatings remain only as laminated paleocarbonate encompassed by pendants of more recent carbonate.

\subsubsection{Clay Accumulation}

Another key criterion used to identify the solum (A and B horizon) of a soil is the translocation and accumulation of clay and clay-sized minerals in B horizons (Soil Survey Division Staff, 1993). In general, horizons that retain sedimentary bedding ( $\mathrm{C}$ and some BC horizons) have very little, if any, clay accumulation. In B horizons, clay may coat the surfaces or corners of peds or the contacts between peds and fine pebbles. Transitional BA horizons may or may not show evidence of clay accumulation. 


\subsection{Relationship of Soils and Geomorphic Surfaces}

Development of the geomorphic surface map for Yucca Flat (Section 5, Plate 3) documented and utilized the soil-surface relationships that occur across the landscape. Soils associated with Late Holocene surfaces (S6 and S7 constructional surfaces) are limited to a weak A horizon, whereas soils associated with Early and Middle Holocene surfaces (S5 constructional surfaces) have structural or color B horizons, with some evidence of carbonate accumulation (Stage I or Stage I+). An eolian mantle effects the development of older soils. Soils of Late Pleistocene surfaces (S4 constructional surfaces) have thicker B horizons than those of the oldest Holocene soils. The B horizons contain more secondary carbonate (Stage I+ to Stage II) and can show evidence of clay accumulation (weakly developed Btk horizons). The Middle Pleistocene surfaces (S3 constructional surfaces) typically have soils with Bt horizons developed in the eolian mantle, if the mantle has not been truncated by erosion. These soils also have B horizons with Stage II to Stage III carbonate accumulation, as well as some silica. The most welldeveloped soils with regard to accumulation of clay and secondary carbonate are associated with the Early Pleistocene surfaces (S2 surfaces). These soils are almost universally truncated, leaving thick, indurated, carbonate-rich B horizons (Stage III to Stage IV) near the land surface. 


\subsection{REFERENCES}

Barth, D. S., Mason, B. J., Starks, T. H., and Brown, K. W., 1989, Soil sampling quality assurance guide, (2nd ed.), EPA/600/8-89/046: Las Vegas, U.S. Environmental Protection Agency, 260 p.

Bechtel Nevada, 1998a, Hydrogeologic characterization of U-3at collapse zone: data report: Las Vegas, Bechtel Nevada, prepared for U.S. Department of Energy, Nevada Operations Office, paginated by section.

Bechtel Nevada, 1998b, Hydrogeologic characterization of U-3bh collapse zone: Las Vegas, Bechtel Nevada, prepared for U.S. Department of Energy, Nevada Operations Office, paginated by section.

Bechtel Nevada, 1998c, Hydrogeologic characterization of U-3bl collapse zone: Las Vegas, Bechtel Nevada, prepared for U.S. Department of Energy, Nevada Operations Office, paginated by section.

Bechtel Nevada, 2006, A Hydrostratigraphic Model and Alternatives for the Groundwater Flow and Contaminant Transport Model of Corrective Action Unit 97; Yucca Flat-Climax Mine, Lincoln and Nye Counties, Nevada, prepared for the U.S. Department of Energy, Nevada Site Office

Birkeland, P. W., 1984, Soils and geomorphology: New York, Oxford University Press, 372 p.

Byers, G. E., Van Remortel, R. D., and Snyder, K. E., 1996, Quality assurance report for a soil characterization study at the Area 5 Radioactive Waste Management Facility, Nevada Test Site, Nye County, Nevada: Las Vegas, Bechtel Nevada, prepared for U.S. Department of Energy, Nevada Operations Office, paginated by section.

Carr, W.J., 1965, Preliminary results of subsurface investigations of fractures in Yucca Flat, Nevada Test Site: U.S. Geological Survey Technical Letter Yucca-57, 15 p.

Christiansen, R. L., and Lipman, P. W., 1972, Cenozoic volcanism and plate tectonic evolution of the western United States, II, Late Cenozoic: Philosophical Transactions Royal Society of London, Series A, v. 271, p. 249-284.

Cole, J.C., Wahl, R.R., and Hudson, M.R., 1989, Structural relations within the Paleozoic basement of Mine Mountain block; implications for interpretation of gravity data in Yucca Flat, Nevada Test Site, in Olsen, C.W., and Carter, J.A., eds., Proceedings of the Fifth Symposium on Containment of Underground Nuclear Explosions: Lawrence Livermore National Laboratory Proceedings, CONF-850953, p. 431-456.

Colton, R.B., and McKay, E.J., 1966, Geologic map of the Yucca Flat Quadrangle, Nye and Lincoln Counties, Nevada: U.S. Geological Survey Geologic Quadrangle Map GQ-582, scale $1: 24,000$.

Conner, C.B., and Hill, B.E., 1995, Three nonhomogeneous Poisson Models for the probability of basaltic volcanism: Application to the Yucca Mountain region, Nevada: Journal of Geophysical Research, v. 100, no. 10, p. 107-110.

Corchary, G. S., and Barnes, H., 1966a, Surface effects mapped in Yucca Flat, Nevada Test Site, through March 1, 1966: U.S. Geological Survey Technical Letter NTS-91, Supplement 2, $4 \mathrm{p}$. 
Corchary, G. S. and Barnes, H., 1966b, Surface effects mapped in Yucca Flat, Nevada Test Site, through June 30, 1966: U.S. Geological Survey Technical Letter NTS-91, Supplement 3, $4 \mathrm{p}$.

Crowe, B. M., 1990, Basaltic episodes of the Yucca Mountain region, in Proceedings High Level Radioactive Waste Management, International Conference, Las Vegas, NV: La Grange, Il., American Nuclear Society, p. 65-73.

Crowe, B. M., and Perry, F. V., 1989, Volcanic probability calculations for the Yucca Mountain Site; estimation of volcanic rates, in nuclear waste isolation in the unsaturated zone: Focus '89 Proceedings, American Nuclear Society, p. 326-334.

Crowe, B.M., Perry F., Geissman, J.. McFadden, L., Wells, S., Murrell, M., Poths, J., Valentine, G.A., Bowker, L., and Finnegan, K., 1995, Status of volcanism studies for the Yucca Mountain site characterization project: Los Alamos, Los Alamos National Laboratory report LA-12908-MS, pp. 1-363.

Crowe, B. M., Vaniman, M. T., and Carr, W. J., 1983, Status of volcanic hazard studies for the Nevada nuclear waste storage investigations: Los Alamos, Los Alamos National Laboratory report LA-9325-MS, $47 \mathrm{p}$.

Crowe, B.M., Wallmann, P., and Bowker, L.M., 1998, “Chapter 6: Probabilistic Modeling of Volcanism Data: Final Volcanic Hazard Studies for the Yucca Mountain Site," in Perry, F., Crowe, B.M., Valentine, G.A., Geissman, J., McFadden, L., Wells, S., Murrell, M., Poths, J., and Bowker, L., Volcanism Synthesis Report: Los Alamos, Los Alamos National Laboratory report.

Crowe, B. M., Wohletz, K. H., Vaniman, D. T., Gladney, E., and Bower, N., 1986, Status of volcanic hazards studies for the Nevada nuclear waste storage investigations: Los Alamos, Los Alamos National Laboratory report LA-9325-MS, 101 p.

Davis, R. E., Summary maps of surface effects mapped in Yucca Flat, Nevada Test Site, January 1, 1964, through June 30, 1964: U.S. Geological Survey Technical Letter NTS-91, 2 p.

Dickey, D.D., 1968, Fault displacement as a result of underground nuclear explosions, in Eckel, E.B., ed., Nevada Test Site: Geological Society of America Memoir 110, p. 219-232.

DOE, 1999, Radioactive Waste Management: Department of Energy Order 435.1

DOE, 1996, Guidance for a Composite Analysis of the impact of interacting source terms of the radiological protection of the public from Department of Energy low-level waste disposal facilities: Washington, D.C., paginated by section.

DOE, 1995, Nevada Test Site annual environmental report-1994: Las Vegas, Nevada Operations Office, U.S. Department of Energy Report DOE/NV11432-175 (UC-600), paginated by section.

DOE, 1988, Radiaoctive Waste Management, chap. 3 of Management of Low-Level Waste: Department of Energy Order 5820.2A, paginated by section.

Dockery-Ander, H.A., 1984, Rotation of late Cenozoic extensional stress, Yucca Flat region, Nevada Test Site, Nevada: Houston, Rice University, Ph.D. dissertation, 77 p. 
Drellack, S.L., Jr., 1995a, Subsurface geologic maps of southern Yucca Flat: Las Vegas, Raytheon Services Nevada memorandum TSP:DGP:024:95 to Ed Price, 1 p., 1 map sheet, scale 1:24,000.

Drellack, S.L., Jr., 1995b, Descriptive narrative for cross sections SD1, SD2, SD3 and MS1: Las Vegas, Raytheon Services Nevada Memorandum No. TSP:DGP:043:95 to Edwin Price $19 \mathrm{p}$.

Drellack, S.L., Jr., 1994a, Isopach map of the alluvium in southern Yucca Flat: Las Vegas, Raytheon Services Nevada Memorandum No. TSP:DGP:088:94, 1 p., 1 map sheet, scale $1: 24,000$.

Drellack, S. L., Jr., 1994b, Structure contour map of the top of the Rainier Mesa Tuff in LANL use areas, Yucca Flat, NTS, revision 3: LANL Geologic Support Group Map TMRSC1.DGN, scale: 1:24,000.

Drellack, S. L., Jr., and Thompson, P.H., 1990, Selected stratigraphic data for drill holes in LANL use areas of Yucca Flat: Las Vegas, U.S. Department of Energy Report DOE/NV/10322-39, 192 p.

Elwood, R., McKague, L.H., and Wagoner, J., 1985, Evidence for syntectonic activity during alluvial deposition, Yucca Flat, Nevada, in Olsen, C.W., and Carter, J.A., eds., Proceedings of the Fifth Symposium on Containment of Underground Nuclear Explosions: Lawrence Livermore National Laboratory Proceedings, CONF-850953, p. 46-51.

Emerick, W.L. and Davis, R.E., 1965, Surface effects mapped in Yucca Flat, Nevada Test Site, January 1, 1964 through June 30, 1965: U.S. Geological Survey Technical Letter NTS91, Supplement 1, 2 p.

Emerick, W.L., January 1963, Effects of experimental shot in drill hole U3bj, Area 3, Nevada Test Site, Nye County, Nevada: U.S. Geological Survey Technical Letter Yucca-38, 6 p.

Ferguson, J.F., 1981, Geophysical investigations of Yucca Flat: Dallas, Southern Methodist University, Ph.D. dissertation, 110 p.

Fernald, A. T., Corchary, G. S., and Williams, W. P., 1968, Surficial geologic map of Yucca Flat, Nye and Lincoln Counties, Nevada: U.S. Geologic Survey Miscellaneous Geologic Investigations Map I-550, scale 1:48,000.

Forbes, T., Rossiter, D., and Van Wambeke, A., 1987, Guidelines for evaluating the adequacy of soil resource inventories: Washington, D.C., Soil Management Support Services and U.S. Department of Agriculture Soil Conservation Service, 51 p.

French, R.H., 1993, FY-93 evaporation studies at ER 6-1 ponds: Las Vegas, Desert Research Institute letter report to Stephen J. Lawrence, U.S. DOE, 20 p.

Frizzel, J. A., Jr., and Shulters, J., 1990, Geologic Map of the Nevada Test Site, Southern Nevada: U.S. Geologic Survey Miscellaneous Investigations Series Map I-2046, scale $1: 100,000$.

Geomatrix Consultants, Inc., 1996, Probabilistic volcanic hazard analysis for Yucca Mountain, Nevada: Las Vegas, Civilian Radioactive Waste Management System, BA000000001717-2200-00082. 
Gile, L. H., Peterson, F. F., and Grossman, R. B., 1966, Morphological and genetic sequences of carbonate accumulation in desert soils: Soil Science, v. 101, p. 347-360.

Hazelwood, R. M., D. L. Healey, and C. H. Miller, 1963. U.S. Geological survey investigations of Yucca Flat, Nevada Test Site, Part B-geophysical investigations. U.S. Geological Survey Technical Letter NTS-45, 53 p.

Healy, D.L., 1963, Correlation of gravity data and faulting in Yucca Flat, Nevada Test Site: U.S. Geological Survey Technical Letter Yucca-43, 11 p.

Hoover, D.L., Swadley, W.C., and Gordon, A.J., 1981, Correlation characteristics of surficial deposits with a description of surficial stratigraphy in the Nevada Test Site region: U.S. Geological Survey Open-File Report 81-512, 27 p.

Huckins-Gang, H.E., Rawlinson, S.E., Snyder, K.E., and Gustafson, D.L., 1995a, Geomorphic surface map of northern Frenchman Flat, southern Nevada, Sheet 4: Las Vegas, Raytheon Services Nevada and Lockheed Environmental Systems and Technologies Company, prepared for the U.S. Department of Energy Nevada Field Office, scale $1: 6,000$.

Huckins-Gang, H.E., Rawlinson, S.E., Snyder, K.E., and Gustafson, D.L., 1995b, Geomorphic surface map of northern Frenchman Flat, southern Nevada, Sheet 6: Las Vegas, Raytheon Services Nevada and Lockheed Environmental Systems and Technologies Company, prepared for the U.S. Department of Energy Nevada Field Office, scale $1: 6,000$.

Huckins-Gang, H.E., Rawlinson, S.E., Snyder, K.E., and Gustafson, D.L., 1995c, Geomorphic surface map of northern Frenchman Flat, southern Nevada, Sheet 7: Las Vegas, Raytheon Services Nevada and Lockheed Environmental Systems and Technologies Company, prepared for the U.S. Department of Energy Nevada Field Office, scale $1: 6,000$.

Knauss, K.G., 1981, Dating fault associated Quaternary material from the Nevada Test Site using Uranium-series method: Livermore, Lawrence Livermore National Laboratory report UCRL-53231, $51 \mathrm{p}$.

Marvin, R.F., Mehnert, H.H., and Naeser, C. W., 1989, U.S. Geological Survey Radiometric Ages-Compilation "C": Isochron/West, n. 52, p. 3-11.

McCall, R.L., 1995, Descriptive narrative for cross sections BM1-5: Las Vegas, Raytheon Services Nevada Memorandum No. TSP:DGP:041:95 to Edwin Price, 10 p.

McKeown, F. A., and Dickey, D. D., 1967, Map of explosion-produced fractures in Yucca Valley, Nevada Test Site: U.S. Geological Survey Technical Letter NTS-195, 4 p.

Miller, J. J., 1996, Flood Assessment for the Area 3 Radioactive Waste Management Site, Nevada Test Site, Nye County, Nevada: Las Vegas, Bechtel Nevada, prepared for U.S. Department of Energy, Nevada Operations Office, paginated by section.

Morris, R.H., 1996, Information about lineament mapping along the Area 3 Fault and East Branch Area 3 Fault; Denver, U.S. Geological Survey (Retired) letter report to Heather Huckins-Gang, Bechtel Nevada, 2 p.

Morris, R.H., 1965, Preliminary report of lineament studies of Yucca Flat Nevada Test Site, Nevada: U.S. Geological Survey Technical Letter NTS-140, 7 p. 
Namco International, Inc., 1962, Seismic survey report, Nevada Test Site Area No. 3, Nye County, Nevada: Dallas, Namco International, Inc., submitted to U.S. Coast and Geodetic Survey, unpaginated.

National Geophysical Company, Inc., 1965, Seismic survey report, Nevada Test Site, Areas 1, 2, 3, 4, 5, 6, 8, and 7, Nye County, Nevada: Dallas, National Geophysical Company, Inc., submitted to U.S. Coast and Geodetic Survey, unpaginated.

National Geophysical Company, Inc., 1964, Seismic survey report, second supplement, Nevada Test Site, Areas $3 \& 7$, Nye County, Nevada: Dallas, National Geophysical Company, Inc., submitted to U.S. Coastal and Geodetic Survey, unpaginated.

National Geophysical Company, Inc. (Formerly Namco International, Inc.), 1963, Seismic survey report, Nevada Test Site, Area No. 3--supplement, Nye County, Nevada: Dallas, National Geophysical Company, Inc., submitted to U.S. Coast and Geodetic Survey, unpaginated.

NIST, 1992, Spatial data quality, part 1, chap. 3, in National Institute of Standards and Technology, Spatial Data Transfer Standard, Federal Information Processing Standard 173: Washington, D.C., U.S. Department of Commerce, National Institute of Standards and Technology, paginated by section.

Orkild, P.P., 1983, Geology of Nevada Test Site, in Hudson, B.C., Jones, E.M., Keller, C.E., and Smith, C.W., eds., Proceedings of the Monterey Containment Symposium, Monterey, Calif., August 26-28, 1981: Monterey, Los Alamos National Laboratory report LA-9211C, v. 1, p. 323-338.

Quiring, R.F., 1968, Climatological data for the Nevada Test Site and Nuclear Rocket Development Station: Las Vegas, ESSA Research Laboratories report ERLTM-ARL-7, paginated by section.

Ratcliff, C. D., Geissman, J. W., Perry, F. V., Crowe, B. M., and Zeitler, P. K., 1994, Paleomagnetic record of a geomagnetic field reversal from Late Miocene mafic intrusions, southern Nevada: Science, v. 266, p. 412-416.

Schmeltzer, J.S., Barker, L.E., and Blout, D.O., 1996, Site characterization data from the U3ax/bl exploratory boreholes at the Nevada Test Site: Las Vegas, Bechtel Nevada, prepared for U.S. Department of Energy, Nevada Operations Office, DOE Report DOE/NV/11718003 , paginated by section. 
Shroba, R. R., Muhs, D.R., and Rosholt, J.N., 1988, Physical properties and radiometric age estimates of surficial and fracture-fill deposits along a portion of the Carpetbag fault system, Nevada Test Site, Nye County, Nevada: U.S. Geological Survey Report DOE/NV/10583-1, $34 \mathrm{p}$.

Snyder, R. P., and Rogers, S., 1972, Explosion-induced surface fractures of selected announced underground nuclear tests, Yucca Flat, Nevada Test Site, Nevada, October 1969 through December 1970: U.S. Geological Survey Report NTS-231 (USGS-474-133), 57 p.

Snyder, K. E., Byers, G. E., and Van Remortel, R. D., 1996, Handbook of Laboratory Methods of Soil Analysis: Las Vegas, Bechtel Nevada, prepared for U.S. Department of Energy, Nevada Operations Office, DOE Report DOE/NV/11718-074, 68 p.

Snyder, K. E., Huckins-Gang, H.E., Rawlinson, S.E., and Gustafson, D.L., 1995a, Geomorphic surface map of northern Frenchman Flat, southern Nevada, Sheet 2: Las Vegas, Raytheon Services Nevada and Lockheed Environmental Systems and Technologies Company, prepared for the U.S. Department of Energy Nevada Field Office, scale $1: 6,000$.

Snyder, K.E., Huckins-Gang, H.E., Rawlinson, S.E., and Gustafson, D.L., 1995b, Geomorphic surface map of northern Frenchman Flat, southern Nevada, Sheet 5: Las Vegas, Raytheon Services Nevada and Lockheed Environmental Systems and Technologies Company, prepared for the U.S. Department of Energy Nevada Field Office, scale $1: 6,000$.

Snyder, K.E., Huckins-Gang, H.E., Rawlinson, S.E., and Gustafson, D.L., 1995c, Geomorphic surface map of northern Frenchman Flat, southern Nevada, Sheet 8: Las Vegas, Raytheon Services Nevada and Lockheed Environmental Systems and Technologies Company, prepared for the U.S. Department of Energy Nevada Field Office, scale $1: 6,000$.

Snyder, K.E., Rawlinson, S.E., Huckins-Gang, H.E., and Gustafson, D.L., 1995d, Geomorphic surface map of northern Frenchman Flat, southern Nevada, Sheet 3: Las Vegas, Raytheon Services Nevada and Lockheed Environmental Systems and Technologies Company, prepared for the U.S. Department of Energy Nevada Field Office, scale $1: 6,000$.

Snyder, K.E., S.M. Parsons, and D.L. Gustafson, 1993. Field results of subsurface geologic mapping at the Area 5 Radioactive Waste Management Site, DOE Nevada Test Site, Nye County, Nevada. Raytheon Services Nevada, Las Vegas, Nevada, 24 p + Appendices.

Soil Survey Division Staff, 1993, Examination and description of soils, chap. 3, in Soil survey manual, U.S. Department of Agriculture Handbook No. 18: Washington, D.C., U.S. Government Printing Office, p. 59-195.

Soil Survey Division Staff, 1994, Keys to soil taxonomy (6th ed.): Washington, D.C., U.S. Department of Agriculture Soil Conservation Service, 306 p.

Swadley, W. C., and Hoover, D. L., 1990, Geologic map of the surficial deposits of the Yucca Flat area, Nye County, Nevada: U.S. Geological Survey Miscellaneous Investigations Series Map I-2047, scale 1:48,000.

U.S. Geological Survey (USGS), unpublished, Surface effects compilation map [Yucca Flat, Nevada Test Site, Nye County, Nevada]: scale 1:12,000. 
Van Remortel, R.D., Lee, Y.J., and Snyder, K.E., 1997, Soil characterization database for the Area 3 Radioactive Waste Management Site, Nevada Test Site, Nye County, Nevada: Las Vegas, Bechtel Nevada, prepared for U.S. Department of Energy, Nevada Operations Office, paginated by section.

Williams, W.P., 1964a, Surface effects of the Bilby test, U3cn Site, September 1963, Area 3, Yucca Flat, Nevada Test Site: U.S. Geological Survey Technical Letter NTS-68, 17 p.

Williams, W. P., 1964b, Surface effects from underground tests at the U3cp and U3dl Sites, Yucca Flat, Nevada Test Site: U.S. Geological Survey Technical Letter NTS-96, 10 p.

Williams, W.P., Emerick, W.L., and Davis, R.E., 1963, Geologic appraisal of the U-3cs site and vicinity, Area 3, Yucca Flat, Nevada Test Site: U.S. Geological Survey Technical Letter Yucca-53, 13 p. 


\section{APPENDIX A ANNOTATED BIBLIOGRAPHY}


This page interond y lot blats 
The following annotated bibliography is in chronological order. Observations specifically relevant to the Area 3 fault or other fault-related features are summarized for each entry. Editorial notes and interpretations are presented in italics. Fractures and test sites discussed in this appendix are shown on Plate 2. Pretesting lineaments and geophysically inferred faults from previous studies are shown on Plate 4.

\section{Namco International, Inc., December 1962, Seismic survey report, Nevada Test Site Area No. 3, Nye County, Nevada: Dallas, Namco International, Inc., submitted to U.S. Coast and Geodetic Survey, unpaginated.}

Seismic reflection and refraction surveys were undertaken south of the Area 3 RWMS to determine whether faults are present near designated test sites, and whether seismic methods would depict the position of the Yucca fault in the immediate area. The study consisted of three seismic lines, with Line 1 trending N65EW and 1,500 ft (460 m) south of U3bj. Seismic refraction yielded unusable data and was abandoned in favor of seismic reflection.

Two reflecting horizons were noted on the seismic profiles. An "outstanding" reflection was termed " $\mathrm{A}$ " and thought to represent the base of alluvium. The depth of the alluvium at SP [shot point] 8 is $1,550 \mathrm{ft}(470 \mathrm{~m})$. The second reflection, termed " $\mathrm{B}$ ", “. . . is approximately $200 \mathrm{ft}$ [60 m] deeper and is probably associated with a member within Oak Springs." Oak Springs was the formation name used at that time for the entire section of Tertiary volcanic rocks. The "Magnitude of faulting on Reflection ' $B$ ' is approximately the same as that on Reflection 'A'." No usable deeper reflections were obtained because "Such reflections are obscured by interference of reflections migrating from steep flanks to the east and west." The authors state ". . . data on Line 3 near the Yucca fault are too poor for fault interpretation."

Three normal faults at the base of alluvium were interpreted on the basis of Lines 1 and 2 . The most westerly fault, "A", was interpreted from "fair to good" evidence on Lines 1 and 2 to have a throw of approximately $150 \mathrm{ft}(45 \mathrm{~m})$ up to the west. Based on the sheets, fault "A" on Reflection "A" passes about 2,000 ft $(610 \mathrm{~m})$ west of the Area 3 fault as later mapped through U3bj. "The fault evidence [of fault "B"] on Line 1 is fair and on Line 2 is poor." The maximum throw was interpreted to be $65 \mathrm{ft}(20 \mathrm{~m})$ up to the west. On Reflection "A", fault "B" passes $1,000 \mathrm{ft}(305 \mathrm{~m})$ to the east of U3bj. The most easterly fault was designated fault "C," but evidence was ". . . poor on both Lines 1 and 2 ..." In summary, the authors state: "The seismic reflection data obtained in the area surveyed definitely indicate two normal faults with strike approximately N22EE, and a throw at the base of the alluvium of 65 to 150 feet [20 to $45 \mathrm{~m}$ ]. A third similar fault is probably existent."

The only drill hole data available for the area of this study is the log of Ue3c (Dixon et al, 1973); the log shows that Reflection "A" is probably the top of the Rainier Mesa Member of the Timber Mountain Tuff (Tmr) in this area. 


\section{Emerick, W. L., January 1963, Effects of experimental shot in drill hole U3bj, Area 3, Nevada Test Site, Nye County, Nevada: U.S. Geological Survey Technical Letter Yucca-38, 6 p.}

The test at U3bj (BANDICOOT; September 19, 1962; 12.5 kiloton (kt) [DOE, 1994]) formed a nearly vertical crack trending $10 \mathrm{E}$ to $15 \mathrm{E}$ northeast in the U3bj collapse sink and, on the same trend, a 140-foot- (40-m)-wide zone of cracks extending from the collapse sink about 1,000 ft $(305 \mathrm{~m})$ to a point $100 \mathrm{ft}(30 \mathrm{~m})$ from the southeast rim of the U3bh collapse sink. This was the first expression noted of the Area 3 fault, although it was not named as such at this time. The field check for cracks extended $5,000 \mathrm{ft}(1,520 \mathrm{~m})$ from approximately $1,500 \mathrm{ft}(460 \mathrm{~m})$ south of U3bj to approximately $1,500 \mathrm{ft}(460 \mathrm{~m})$ north of U3bk. The cracks, most less than $0.125 \mathrm{in}$. (3 $\mathrm{mm}$ ) wide, were found both north and south of U3bj. Only two cracks were south of U3bj, a distance of 800 to $1,000 \mathrm{ft}$ ( 240 to $305 \mathrm{~m}$ ) from the crater, and cracks north of U3bj extended from that crater to within $100 \mathrm{ft}(30 \mathrm{~m})$ of U3bh crater [approximately 1,000 ft $(305 \mathrm{~m})$ northeast from $U 3 b j]$.

Emerick also mentions a "northeast trending fracture or zone of weakness hundreds of feet long" extending from U3ak. These fractures do not appear on subsequent compilation surface effects maps.

\section{Colton, R. B., February 1963, Fault traces in alluvium and in Rhyolite Hills in Areas 3, 7, 9, 10, and 15, Yucca Flat, Nevada Test Site: U.S. Geological Survey Technical Letter Yucca-41, 5 p.}

The objective of the study was "... to determine if natural fault traces or other surface indications of natural fractures in the alluvium could be detected; particular attention was given to the area around drill hole site U3bj where a north-northeast-trending fissure was produced by the explosion." [subsequently defined as part of the Area 3 fault]. The author examined 1:12,000-scale aerial photos taken June 6, 1962 [prior to the U3bj (BANDICOOT) event on October 19, 1962], and earlier 1:40,000-scale and 1:60,000-scale aerial photos. "No lineation could be seen on these pre-U3bj photographs [1:12,000-scale photos] to suggest that a fault, joint, or fissure existed in this area prior to the event." Other areas of north Yucca Flat also were examined. "All such lineations that could be detected on the photos apparently are offshoots of the Yucca fault. The Yucca fault... is actually a fault zone, in places as much as 3,000 ft [915 m] in width." 


\section{National Geophysical Company, Inc. (formerly Namco International, Inc.), February and March 1963, Seismic survey report, Nevada Test Site, Area No. 3-supplement, Nye County, Nevada: Dallas, National Geophysical Company, Inc., submitted to U.S. Coast and Geodetic Survey, unpaginated.}

The study added four new seismic reflection lines to the previous seismic study by Namco (Namco International Inc. (December 1962). The objectives of the supplemental seismic lines were to expand the reflection program of December 1962, which was to determine the presence or absence of faulting in Area 3; and to determine whether shallow reflections in the alluvium could be obtained to correlate with difficult drilling conditions in the alluvium.

The new lines were in Area 3 north of the previous study. Three lines trended $560^{\circ} \mathrm{E}$ and northsouth. Deviations occur in the assigned lines because of collapse sinks, structures, and test sites. The two reflections (A and B) found in the initial survey were discernable in these new seismic lines.

Enclosure \#3 (Structure contour map of Horizon "A") from this report shows three faults east of the Yucca fault. Fault "A" is an extension of "A" from the first study. The fault is bent into a north-south orientation and brought north into the area of the U3ax collapse sink to an area of poor continuity on Line 6, and ends before reaching Line 5. The southern part of fault " $\mathrm{B}$ " is unchanged from the previous Namco report. The northern part of fault " $\mathrm{B}$ " was changed to an orientation of N7EE by a bend just north of Line 1 and shown to pass through U3bj (BANDICOOT). This could indicate that the U3bj fracture zone influenced the interpretation of the seismic data, but the fault is not drawn with the same orientation as the BANDICOOT fractures, which were N10-15EE (Entry 2). Fault "B," as mapped in this report, extends with an average trend of $\mathrm{N} 12 \mathrm{EE}$ as far north as $842,100 \mathrm{~N}, 690,350 \mathrm{E}$, roughly the position and orientation of the as yet unknown Area 3 fault. Fault "C," the easternmost besides the Yucca fault, is shown as a dashed line. The easternmost fault from the previous Namco study (Entry 1), fault "C," is not the same as fault " $C$ " in this report; it was deleted because it was not seen on Lines 5 and 6.

"The fault relations near $838,000 \mathrm{~N}-690,000 \mathrm{E}$ are open to question. However, Oak Springs elevations derived from U3bf and U3bt definitely confirm fault ' $\mathrm{C}$ ' on Line 4 . This relation requires faulting to occur near the coordinates given above, but the data are locally poor."

Why the authors reached this conclusion is unclear. The elevation of the base of the alluvium in U3bf, on the side of the fault mapped as downthrown, is 3,000 ft $(915 \mathrm{~m})$, and in U3bt, on the side mapped as upthrown, it is 2,870 ft $(875 \mathrm{~m})$. The elevations at the top of the Rainier Mesa Member in drill holes U3bf and U3bt are 2,860 and 2,730 ft (870 and $830 \mathrm{~m}$ ), respectively (Drellack and Thompson, 1990). The coordinates mentioned (838,000N-690,000E) are not near fault " $C$ " but are on fault " $B$ " near the N42EE branch just south of U3cn (BILBY). 


\section{Healey, D. L., March 1963, Correlation of gravity data and faulting in Yucca Flat, Nevada Test Site: U.S. Geological Survey Technical Letter Yucca-43, 11 p.}

Faults inferred from gravity data are shown on a map in this report, The Area 3 fault is not shown.

\section{Hazlewood, R. M., Healey, D. L., and Miller, C. H., April 1963, U.S. Geological Survey investigations of Yucca Flat, Nevada Test Site, Part B-geophysical investigations: U.S. Geological Survey Technical Letter NTS-45, 53 p.}

This report contains a Bouguer gravity map of the Yucca Flat area, and a structure contour map of the upper surface of the pre-Cenozoic [Paleozoic] rocks. Two closed gravity anomalies occur north of the Area 3 fault. The western anomaly is a gravity high and the eastern anomaly is a gravity low.

The two anomalies might be interpreted as straddling the northward projection of the fault, with the east side down. However, based on the structure contour map, the high-and low-gravity anomalies might correspond, respectively, to a topographic high and a low in the surface of the pre-Cenozoic rocks. Varying lithologies are an alternative explanation for the gravity differences. Few boreholes in Yucca Flat penetrate into the pre-Cenozoic rocks so control is limited.

\section{Williams, W. P., Emerick, W. L., and Davis, R. E., November 1963, Geologic appraisal of the U-3cs Site and vicinity, Area 3, Yucca Flat, Nevada Test Site: U.S. Geological Survey Technical Letter Yucca-53, 13 p.}

The purpose of the study was "... to briefly recount the evidence in support of the existence of this zone of weakness [Area 3 fault] and to review the geologic setting of the U-3cs site ...". "The U-3cs site lies about 2,700 ft [820 m] southeast of the Bilby [U3cn] ground zero and is roughly on a zone of fractures defined in the alluvium that trends about N18EE through sites U-3bj (BANDICOOT) and U-3cq (abandoned) (approximately 2,700 ft [820 m] east of BILBY ground zero)," ". . . and is herein referred to as the Area 3 fault." The width of the zone of weakness related to the Area 3 fault near U-3cs and U-3cq is 600 to $700 \mathrm{ft}$ ( 183 to $213 \mathrm{~m}$ ).

The report, published shortly after the September 1963 BILBY test (Entry 8), includes a drawing of the BILBY surface effects. Mentioned in the text is the pre-BILBY collapse of the largediameter drill hole U-3cq within the "BILBY fracture zone." This collapse is taken as evidence that $U$-3cq is on the Area 3 fault. The Area 3 fault has consistently been drawn through $U-3 c q$ on subsequent plan maps.

"A gap in the continuity of the surface cracks, about 2,500 ft $(760 \mathrm{~m})$ long . .." ". . exists in the area centrally located between U-3cs and U-3bj." This gap is not considered significant because of the alignment of the two zones (of cracks) and their persistence both north and south (of the gap). The U-3cs site, which is shown to be on the Area 3 fault in the 1:24,000-scale sketch map and about $70 \mathrm{ft}(20 \mathrm{~m})$ southeast of the zone on the larger scale location map, was later abandoned as a test location. 


\section{Williams, W. P., February 1964, Surface effects of the Bilby event, U3cn Site, September 1963, Area 3, Yucca Flat, Nevada Test Site: U.S. Geological Survey Technical Letter NTS-68, 17 p.}

After the event at U3cn (BILBY; September 13, 1963; $249 \mathrm{kt}$ [DOE, 1994]), Williams mapped a northeast-trending zone of fractures "traceable, though not continuously, for a total distance of $9,000 \mathrm{ft}[2,740 \mathrm{~m}] . "$ Williams tentatively called this feature the Area 3 fault [he first used this term in November 1963 in his (and others) report on U-3cs] and postulated that it may connect with the BANDICOOT fractures, thereby increasing its length to $14,000 \mathrm{ft}(4,270 \mathrm{~m})$. Williams noted that the southwestern extent of the Area 3 fault was somewhat indeterminate ". . because with increasing distance from ground zero it becomes increasingly difficult to differentiate between what might be a waning Bilby effect and an effect from another smaller, but closer event." A 3,000-ft (915-m) interval between the southwestern end of the mapped fracture zone and the BANDICOOT fractures is represented on the map accompanying the report by lines interspersed with question marks. This pattern may represent either a zone of fractures that was not obviously an effect of BILBY or the hypothetical connection of the two zones (Entry 7). However, the lines and question marks probably do not represent mapped fractures because of the pattern's straightness and regular spacing. A down-to-the-west displacement of 6 in. $(15 \mathrm{~cm})$ was noted on the Area 3 fault about 3,000 ft $(915 \mathrm{~m})$ southwest of the BILBY ground zero, near the U-3da site. However, this displacement is not on the line later drawn as the main trace of the fault. Minor (less than 0.5 -in [1.25-cm]), east-facing scarps were formed northwest and southwest of this scarp. A 5-in (13-cm), west-facing scarp also formed in a road about 4,500 $\mathrm{ft}(1,370 \mathrm{~m})$ northeast of ground zero on the Area 3 fault. The BILBY event also cracked the Yucca fault with as much as 3 in. $(8 \mathrm{~cm})$ of downthrow on the east side, and created other prominent northwest to northeast fracture zones east of ground zero.

\section{National Geophysical Company, Inc., May-July 1964, Seismic survey report, second supplement, Nevada Test Site, Areas 3 \& 7, Nye County, Nevada: Dallas, National Geophysical Company, Inc., submitted to U.S. Coastal and Geodetic Survey, unpaginated.}

This study builds on two previous studies by National Geophysical Company (Entries 1 and 4) with the addition of four seismic reflection lines to the north and three to the south. In the area of interest, on the map entitled "Structural Control for Horizon 'B," fault "A" is unchanged from the first supplement (Entry 4). Fault "B" was extended northeastward to 855,900N, 691,100E, and fault "D" was added to the east in the approximate location of the East Branch Area 3 fault. Fault " $C$ " was extended northeastward and several short, unnamed fault segments were added. Enclosure 1 (Structural Control for Horizon "A") could not be located.

\section{Davis, R. E., July 1964, Summary maps of surface effects mapped in Yucca Flat, Nevada Test Site, January 1, 1964, through June 30, 1964: U.S. Geological Survey Technical Letter NTS-91, (Declassified July 31, 1989), 2 p.}

"Following each event since the beginning of 1964, the area surrounding the site was examined in detail, and fractures other than those that were probably the result of superficial compaction of loose material were recorded. In most instances the mapping was done at a scale of 1 inch equals 500 feet $[1: 6,000]$. The summary maps at 1 inch equals 1,000 feet $[1: 12,000]$ are 
necessarily somewhat generalized, but the location, widths, and lengths of fracture zones are accurately shown."

Fractures can vary from "hairline cracks to fractures with separation of several inches" and such distinctions are not made on the summary maps. "Many if not most of the fractures mapped immediately following an event ... probably have since been obliterated by sand and silt blowing over them or by machinery having passed across the areas. Even many of the fractures representing strong throughgoing structures such as the Yucca and Area 3 faults, have been obliterated since originally formed."

Near the Area 3 fault, new fracture zones shown on this map include: (1) those associated with U-3co (PIPEFISH; April 29, 1964; less than $20 \mathrm{kt}$ [DOE, 1994]) west of U3bj and (2) a northeast-trending zone, about 1,500 ft $(460 \mathrm{~m})$ long, east of and parallel to the Area 3 fault between U3bp and U3bk that is probably related to U3bo (STURGEON; April 15, 1964; less than $20 \mathrm{kt}$ [DOE, 1994]). The Area 3 fault is essentially unchanged from Williams' post-BILBY map (Entry 8). The gap between U3cs and the BANDICOOT fractures is represented by lines interspersed with question marks. The map accompanying this report shows "inferred faults from geophysical data," that apparently were transferred from National Geophysical Company's first Area 3 Supplement (Entry 4), but with no indication of downthrown sides. The fault transferred from National Geophysical's fault " $B$ " parallels much of the Area 3 fault, but diverges northward near U3cs. The line transferred from fault " $\mathrm{A}$ " is shown as trending north-south through U3ax.

\section{Williams, W. P., October 1964, Surface effects from underground tests at the U3cp and U3dl Sites, Yucca Flat, Nevada Test Site: U.S. Geological Survey Technical Letter NTS-96, 10 p.}

Preceding the events at U3cp and U3dl (respectively, CANVASBACK; August 22, 1964; less than $20 \mathrm{kt}$; and HADDOCK; August 28, 1964; less than $20 \mathrm{kt}$ [DOE, 1994]), the surrounding areas within a 2,640-ft $(300-\mathrm{m})$ radius of each of the sites were examined, as were old fractures on the Area 3 fault. U $3 \mathrm{cp}$ is located $1,500 \mathrm{ft}(460 \mathrm{~m})$ west of the Area 3 fault. New fractures formed continuously along the fault for a distance of $2,000 \mathrm{ft}(610 \mathrm{~m})$ as a result of the U3cp event. New fractures also formed at the U3cq site. A "strong system of north-trending fractures [occurred] 300 to 600 feet [90 to 180 meters] west of the Area 3 fault, or about 1,100 feet [335 meters] east of U3cp." "The relation, if any, of these fractures to the Area 3 fault is not clear at this time." The event at U3dl did not fracture the Area 3 fault; ". . . postshot [U3dl] examination [of the surface] did not disclose any new breaks on either the Yucca fault or the Area 3 fault." Neither U3cp or U3dl formed a collapse sink.

As a result of the U3cp event, fractures formed in and just west of "a trench" [USGS Trench D] about $500 \mathrm{ft}(150 \mathrm{~m})$ southwest of drill hole U7b. The fractures ". . . could not be traced north or south from the trench on the surface, nor did the fractures extend upward to the surface of the alluvium." Williams states that the walls of the trench were unfractured prior to the U-3cp event. This statement conflicts with mapping results by Carr (Entry 16). Carr (1965) indicates that " $a$ few inconspicuous, incipient cracks were noted in the trench walls." The conflict with Carr's mapping is probably not significant, although it should be noted. 
12. Williams, W. P., January 1965 , Surface effects from an underground test at the U7b Site, Yucca Flat, Nevada Test Site: U.S. Geological Survey Technical Letter NTS-101, 6 p.

The event at U7b (AUK; October 2, 1964; less than $20 \mathrm{kt}$ [DOE, 1994]) extended the Area 3 fault northward about $2,500 \mathrm{ft}(760 \mathrm{~m})$ from the preshot limit. The new fractures were northsouth trending and formed in two en-echelon zones connected by a short, northeast-trending jog. The northern segment was reportedly the stronger and showed a 2 -in $(5-\mathrm{cm})$ down-to-the-east offset. This sense of offset is in contrast to earlier displacements on the Area 3 fault, which were primarily down to the west. The U7b site is on the east side of the Area 3 fault. USGS Trench D was caved in places by this event.

\section{Emerick, W. L., March 1965, Surface effects from an underground test at the U3ct Site, Yucca Flat, Nevada Test Site: U.S. Geological Survey Technical Letter NTS-109, 6 p.}

The event at U3ct (MERLIN; February 16, 1965; 10.1 kt [DOE, 1994]) did not affect the Area 3 fault significantly. One small fracture related to MERLIN, about $500 \mathrm{ft}(150 \mathrm{~m})$ southeast of drill hole U3ca, is on the Area 3 fault zone within the "gap" noted by Williams (1964) (Entry 8).

\section{Williams, W. P., May 1965, Surface effects from an underground test at the U3an Site,} Yucca Flat, Nevada Test Site: U.S. Geological Survey Technical Letter NTS-120, 8 p.

The Area 3 fault was examined before and after the test at U3an (WAGTAIL; March 3, 1965; 20-200 kt [DOE, 1994]). The U3an site is $9,000 \mathrm{ft}(2,740 \mathrm{~m})$ away from the Area 3 fault. The only effect was a 40-ft- $(15-\mathrm{m})$-wide zone of fractures along the Area 3 fault in a hard-packed cable west of U7b. Fractures were discontinuous, but traced for 1,000 ft $(305 \mathrm{~m})$ north and south of U7b. Away from the U7b site, the zone became single, discontinuous fractures found mostly in hard-packed, graded areas.

\section{National Geophysical Company, Inc., April-June 1965, Seismic survey report, Nevada Test Site, Areas 1, 2, 3, 4, 5, 6, 8, and 7, Nye County, Nevada: National Geophysical Company, Inc., submitted to U.S. Coastal and Geodetic Survey, unpaginated.}

In this study, additional reflection data were obtained in Areas 3 and 7. Objectives were to "determine the feasibility of mapping the Paleozoic surface in Yucca and Frenchman Flats by means of long-range refractions ...", and ". . study a small area located in Area 2 (Site 2-E of Project Discus Thrower) to determine if reflection techniques could here map the Paleozoic surface and depths of alluvium." The report summarizes results of all subsurface data obtained to date; results are presented by NTS area.

Reflections "A" and "B" are still mapped, but the authors no longer identify Reflection "A" as the base of the alluvium and state, "It is probable that this reflection originates from a welded tuff of the Piapi Canyon Formation." In light of the new study, ". . . data are somewhat altered from earlier reports. However, faults ' $\mathrm{A}$ ' 'B' and ' $\mathrm{C}$ ' are located much the same as reported before." 
The northern ends of faults " $\mathrm{B}$ " and " $\mathrm{C}$ " (north of about N842,000) are now shown as dashed, because "faults ' $\mathrm{B}$ ' and ' $\mathrm{C}$ ' and the Yucca fault zone are poor in this area, as indicated on the map. The reflections on the east end of the lines are too shallow to map. The additional data have required new orientations of faults 'D' and 'E.", faults "A," "B," and "C" are shown in this report to be connected to the Yucca fault at their southern ends. Fault "D," which was shown in the 1964 National Geophysical Company report (Entry 9) to be near the East Branch Area 3 fault, is now cut off far to the south (N821,750, E691,350). The northern end of fault " $E$ " is now shown as trending northeast rather than northwest. All faults continue to be shown as downthrown to the east. The Structural Control for Horizon "A" map (Enclosure 2) is apparently the source for the "subsurface fault zones inferred from seismic survey data" shown on the surface effects compilation map accompanying NTS-91, Supplement 3 (Entry 24).

\section{Carr, W. J., June 1965, Preliminary results of subsurface investigation of fractures in Yucca Flat, Nevada Test Site: U.S. Geological Survey Technical Letter Yucca-57, 15 p.}

In August and September 1964, the USGS excavated five fault trenches in Yucca Flat. "The purpose of the trenches was to provide a three-dimensional view of explosion-produced and natural fractures and faults . .." ". . f from which information might be obtained regarding their character and shallow vertical and linear extent." The objective was to establish a clear relation between the explosion-produced fracture and preexisting natural faults or fractures. [This objective was not realized.]

Regarding two of the trenches, "... the fourth [trench] (E) cut across a known zone of intense surface fractures; and the fifth [trench] (D) cut across the northward projection of the Area 3 fault beyond the area where it was marked by surface fractures." "Trench D ". . is about $500 \mathrm{ft}$ [152 m] southwest of the U7b site." "Trench E is located about $200 \mathrm{ft}$ [61 m] north of the sink at U3bj, across the trace of the Area 3 fault." Maps of each trench are included on a single sheet in the report. "Prior to underground testing this [the Area 3] fault had no significant surface expression except for short distances. However, tests in Areas 3 and 7 have produced many surface fractures along this feature, some with as much as 4 inches $[10.3 \mathrm{~cm}]$ of vertical displacement. The pattern of the surface fractures suggests a fairly complex fracture system that is grossly parallel to the Yucca fault zone (Davis, 1964). Events at the U7b and U3cp sites have extended surface fractures along this fault northward into Area 7." "It is certain that the fractures that were mapped on the surface at the time of the original postshot mapping have now been healed or filled by soft material within 5 or $10 \mathrm{ft}[1.5$ or $3.0 \mathrm{~m}]$ of the surface..."

When Trench D was excavated, a few inconspicuous, incipient cracks were noted in the trench walls. After the event at U3cp, numerous cracks with separation as much as $0.5 \mathrm{in} .(1.3 \mathrm{~cm})$ were readily visible near the west end of the trench. Additional new cracking was noted after a test at U9bd, 14,000 ft (4,270 m) away from Trench D. The fractures in Trench D were mostly in two zones, one on the west end, and one on the east end of the trench. Fractures at the western end had an average strike of about N10EW and dipped steeply westward. Fractures at the eastern end appeared to strike north or slightly east of north and dipped eastward. Roots were found in most of the cracks to depths as great as $20 \mathrm{ft}(6 \mathrm{~m})$. These roots were thought by Helen Cannon of the USGS to have grown into cracks formed in 1954 or 1955 . Cracks could have formed at this time due to early testing or natural earthquakes. Trench $\mathrm{D}$ was caved primarily as a result of the event at $U 7 b$. 
Study of Trench E was minimal because it caved rapidly due to the unconsolidated nature of the alluvium. Only minor fractures were observed in the trench and roots were not observed in these fractures.

\section{Emerick, W. L., and Davis, R. E., August 1965, Surface effects mapped in Yucca Flat, Nevada Test Site, January 1, 1964. through June 30, 1965: U.S. Geological Survey Technical Letter NTS-91, Supplement 1, (Declassified July 31, 1989), 2 p.}

This map, the second of three compilation maps by the USGS, shows fractures and "surface fault[s] inferred from seismic survey [source unknown]." Obvious changes in this map relative to NTS-91 (Entry 10) are the addition of an inferred surface fault and fractures between U3cs and the U3bj (BANDICOOT) fracture zone, and deletion of the question marks in this area. All but three of the fractures in this area appear to have been traced from lines with question marks on the BILBY postshot map (NTS-68) and NTS-91 (Entries 8 and 10). Events at U3bx, U3dy, $U 3 d w$, or U3das seem the most likely cause of the remaining three fractures. The queried lines shown on the BILBY postshot map seem not to represent discrete fractures; rather, they serve to suggest a potential zone of weakness. An additional change since the NTS-91 (Entry 10) is a fracture that will later be shown to be coincident with the East Branch Area 3 fault. This fracture probably resulted from the Scaup event at U3das (Entry 22).

18. Barosh, P., August 1965, Preliminary joint study of the northeast border of Yucca Flat and relationships of the joints to the pattern of surface effects produced over underground nuclear explosions: U.S. Geological Survey Technical Letter NTS-139, 19 p.

Barosh concluded that the common northeast trend of explosion-induced fractures in alluvium is sometimes related to the most pervasive set of throughgoing joints in the bedrock, and not to the youngest faults and joints underlying bedrock. On the map accompanying this report, Barosh drew lines of average trend through sets of fractures on the Area 3 fault and elsewhere. This makes the fault look less continuous than on previous maps. For example, although the U3cq drill hole is usually drawn as a point on the trace of the Area 3 fault, the dominant fracture trend around U3cq (according to Barosh) is north-south and not parallel with the trace as usually drawn through this point.

\section{Morris, R. H., September 1965, Preliminary report of lineament studies of Yucca Flat Nevada Test Site, Nevada: U.S. Geological Survey Technical Letter NTS-140, 7 p.}

The objectives of the study were to determine the geologic nature of the lineaments in the northern one-third of Yucca Flat and whether they have any special or casual relation to explosion-produced fractures. Lineaments he mapped included "... alignments of vegetation or stream channels, minor scarps, abrupt or systematic changes in drainage and other features ...". Morris used a series of 1:30,000-scale aerial photos flown in 1951, which predate any underground testing. Maps in the report "... show the lineaments superimposed on the surface effects maps (Emerick et al, 1965) to illustrate their relationship to explosion-produced [fractures]." The lineaments are plotted using two symbols, one representing lineaments without presently demonstrated structural relationships, and the other representing lineaments along which explosion fractures are present and which appear to be related to faults." "Some lineaments, particularly those which trend north-south, are fracturing as a result of underground 
explosions. Some lineaments are related to faults, others are coincident with or project into faults inferred from geophysical or other data." The maps show a ". . persistent or inherent tendency for the explosion-produced fractures to have a northeasterly orientation."

"Few lineaments coincide with the strong northeasterly trend of fractures developed around many ground zeros." No lineaments coincide with the Area 3 fault as mapped from surface effects, except at the northern end of the fault near U7b. A significant feature of this map is a large curving "cracked lineament" to the east of the Area 3 fault. This lineament will be defined later as the East Branch Area 3 fault. Cracks shown on this curving lineament are concentrated around U3das (SCAUP site), but only one of these fractures is indicated on the map showing SCAUP surface effects in NTS-126 (Entry 22); therefore, the origin of the cracks is unknown. Whether these fractures on the northern part prompted Morris to call the entire lineament cracked, or whether there were cracks along the entire lineament is unclear. In light of the lack of testing near the southern end of this lineament and the lack of any previously mapped fractures in this area, the former is probably the case. The map accompanying this report shows faults from National Geophysical's first Area 3 Supplement (Entry 4). There is no geophysically inferred fault parallel to the cracked lineament, later called the East Branch Area 3 fault.

20. Ege, J. R., October 1965, Surface effects from an underground test at the U7g Site, Yucca Flat, Nevada Test Site: U.S. Geological Survey Technical Letter NTS-151, (Declassified August 4, 1989), 4 p.

The event at U7g (CHARCOAL; September 10, 1965; 20-200 kt [DOE, 1994]), located 2,000 ft $(610 \mathrm{~m})$ west of the northern extension of the Area 3 fault zone, did not produce any new fractures along the Area 3 fault. Although ground zero was on one of Morris' (Entry 19) "uncracked lineaments," no fractures were produced on this trend. The map in this report shows a "[s]ubsurface fault inferred from seismic survey," possibly transferred from NTS-91 (Entry 10) or NTS-91 Supplement 1 (Entry 17).

\section{Corchary, G. S., January 1966, Surface effects from an underground test at the U3en Site, Nevada Test Site: U.S. Geological Survey Technical Letter NTS-159, 4 p.}

The event at U3en (SEPIA; November 12, 1965; less than $20 \mathrm{kt}$ [DOE, 1994]) was approximately more than $1,000 \mathrm{ft}(300 \mathrm{~m})$ west of the Area 3 fault segment originally noted as the "gap" between the BILBY fractures and the BANDICOOT fractures by Williams, 1963 (Entry 8). The event produced no fractures on any part of the Area 3 fault.

\section{Emerick, W. L., March 1966, Surface effects from an underground test at the U3das Site, Nevada Test Site: U.S. Geological Survey Technical Letter NTS-126, 2 p.}

The event at U3das (SCAUP; May 14, 1965; less than $20 \mathrm{kt}$ [DOE, 1994]) formed a crater $670 \mathrm{ft}$ $(205 \mathrm{~m})$ in diameter and $12 \mathrm{ft}(4 \mathrm{~m})$ deep, and tangential surface fractures as far as 2,000 ft $(610 \mathrm{~m})$ from surface ground zero. A surface-effects map shows tangential fractures associated primarily with the U3das crater, north-northwest fractures west of the crater, and northwest trending fractures southwest of the crater. The north-northwest and northwest trending fractures together extend for about $1,600 \mathrm{ft}(490 \mathrm{~m})$ along the Area 3 fault approximately between $\mathrm{N} 840,000$ and N842,000. The effects map also shows a single fracture, about $250 \mathrm{ft}(75 \mathrm{~m})$ long, 60 to $120 \mathrm{ft}$ ( 20 to $40 \mathrm{~m}$ ) west of the "cracked lineament" of Morris (Entry 19) that later became the East Branch Area 3 fault. 
23. Corchary, G. S., and Barnes, H., April 1966, Surface effects mapped in Yucca Flat, Nevada Test Site, through March 1, 1966: U.S. Geological Survey Technical Letter NTS-91, Supplement 2, 4 p.

Little change is evident along the Area 3 fault zone between NTS-91, Supplement 1 (Entry 17) and this map. Fractures on the East Branch Area 3 fault are shown near the single fracture mapped in NTS-126 as caused by the SCAUP event (Entry 22). These are the same fractures shown by Morris (Entry 19), and their origin remains unclear. Events since NTS-91, Supplement 1 include CHARCOAL at U7g and SEPIA at U3en (Entries 20 and 21), neither of which affected the Area 3 fault. This map also shows "subsurface faults as inferred from seismic survey" and Morris" lineaments (Entry 19). The subsurface faults are derived from the latest National Geophysical Company report (Entry 15) and are slightly different from those shown on the map accompanying Supplement 1. The main difference is that the three main faults east of the Yucca fault are now shown as joined to the Yucca fault at their southern ends, and the easternmost fault has been deleted. From April 1966 to July 1966 a series of short reports (NTS-91, Supplements 2 a through 2o) was released. These are surface effects reports for individual events. The events closest to the Area 3 fault are at U3cd and U3du, both approximately more than $2,000 \mathrm{ft}(610 \mathrm{~m})$ away from the southern end of the mapped trace. Neither of these events affected the Area 3 fault.

\section{Corchary, G. S. and Barnes, H., July 1966, Surface effects mapped in Yucca Flat, Nevada Test Site, through June 30, 1966: U.S. Geological Survey Technical Letter NTS-91, Supplement 3, (Declassified July 31, 1989), 4 p.}

The map shows the same three "subsurface faults as inferred from seismic data" connected to the Yucca fault as in Supplement 2 (Entry 23), and shows them as all being down to the east. No new fractures since Supplement 2 are shown on this map near the Area 3 fault. One new collapse sink is shown at U3du, about 2,200 ft $(670 \mathrm{~m})$ west of the south end of the Area 3 fault.

\section{McKeown, F. A., and Dickey, D. D., May 1967, Map of explosion-produced fractures in Yucca Valley, Nevada Test Site: U.S. Geological Survey Technical Letter NTS-195, 4 p.}

The map is a compilation of all surface effects mapped between September 1963 and April 1967. "Fractures produced by most of the underground nuclear explosions have been mapped in various amounts of detail by many geologists; hence the style and detail of the mapping vary from place to place on the map. Between September 1963 and July 1996, the fractures produced by all explosions were mapped. Since July 1966, only the fractures of selected explosions have been mapped."

The map, near the Area 3 fault, closely resembles the map in NTS-91, Supplement 3 (Entry 24).

\section{Fernald, A. T., Corchary, G. S., and Williams, W. P., October 1967, Thickness of surficial deposits in Yucca Flat, Nevada Test Site: U.S. Geological Survey Technical letter NTS-194, 2 p.}

The report includes an isopach map of alluvium (Plate 5) that is a revision of an earlier map by Chase (1965), and a structure contour map of the base of the alluvium. The forked trace of the Area 3 fault is dashed on both maps. No relative motion is indicated. Contours at the trace suggest a down-to-the-east sense of motion. 
27. Fernald, A. T., Corchary, G. S., and Williams, W. P., 1968, Surficial geologic map of Yucca Flat Nye and Lincoln Counties, Nevada: Miscellaneous Geologic Investigations Map I-550, scale 1:48,000.

The forked trace of the Area 3 fault is shown on this map as a dashed line representing "fault or lineament ... indefinite or approximately located. Commonly occurs as a crack."

28. Healey, D. L., 1968, Application of gravity data to geologic problems at Nevada Test Site, in Eckel, E. B., (ed.), Nevada Test Site: Geological Society of America Memoir 110, p. 147-156.

The report provides little information not previously presented in Healey, D. L., March 1963, Correlation of gravity data and faulting in Yucca Flat, Nevada Test Site: U.S. Geological Survey Technical Letter Yucca-43, 11 p. (Entry 5).

29. Dickey, D. D., 1968, fault displacement as a result of underground nuclear explosions, in Eckel, E. B., (ed.), Nevada Test Site: Geological Society of America Memoir 110, p. 219-232.

"The Area 3 fault is located about $1.5 \mathrm{mi}(2.4 \mathrm{~km})$ to the east of the Yucca fault in the middle of the valley (Yucca Flat) . . a and trends about N10E E." "A weathered west-facing scarp about $2 \mathrm{ft}$ (0.6 meters) high occurs at some places along the fault, but elsewhere the fault has no noticeable surface relief." "This fault displacement is the result of displacement in the bedrock and does not merely reflect differential compaction of the overlying alluvium." Second to the Yucca fault, "The Area 3 fault is the next most sensitive (to show displacement resulting from underground explosions) and will register displacement if the scaled distance is less than 500 (using the equation $\mathrm{S}=\mathrm{D} / \mathrm{W}^{1 / 3}$, where $\mathrm{S}$ is the scaled distance, $\mathrm{D}$ is the minimum horizontal distance, in feet, between the explosion and the surface trace of the fault, and $\mathrm{W}$ is the yield of explosive, in kilotons equivalent TNT.)"

"Possible explanations for fault displacements"... (A) Explosion-produced stress added to the existing stress field is sufficient to exceed the force of static friction along the fault plane; (B) The vibrations produced by the explosions may reduce friction along the fault, thereby reducing the amount of stress required to cause displacement, and the existing stress field causes the displacement; and (C) A combination of mechanisms (A) and (B) cause displacement."

30. Barosh, P. J., 1968, Relationships of explosion-produced fracture patterns to geologic structure in Yucca Flat, Nevada Test Site, in Eckel, E. B., (ed.), Nevada Test Site: Geological Society of America Memoir 110, p. 199-218.

The report provides little information not previously presented in Barosh, P., August 1965, Preliminary joint study of the northeast border of Yucca Flat and relationships of the joints to the pattern of surface effects produced over underground nuclear explosions: U.S. Geological Survey Technical Letter NTS-139, 19 p. (Entry 18).

31. Fernald, A. T., 1970, Thickness of Surficial Deposits and Tuff in Yucca Flat, Nevada Test Site: U.S. Geological Survey Report NTS-224 (USGS-474-86), 9 p. 
The report includes: (1) a revised isopach map of surficial deposits [originally issued in 1965 as Technical Letter NTS-136, by Livingston Chase], and (2) a structure contour map of the base of Cenozoic rocks derived from drill hole and gravity data. The Area 3 fault is shown to be displaced down to the east. Compare this report with Hazlewood, R. M., Healey, D. L., and Miller; C. H., April 1963, U.S. Geological Survey investigations of Yucca Flat, Nevada Test Site, Part B-geophysical investigations: U.S. Geological Survey Technical Letter NTS-45, 53 p. (Entry 6).

\section{McKeown, F. A., Bucknam, R. C., Dickey, D. D., and Snyder, R. P., 1971, Summary of geologic structural information relative to noncontained and contained nuclear explosions: U.S. Geological Survey Administrative Report, 71 p.}

Venting of the BANDICOOT event at $\mathrm{U} 3 \mathrm{bj}$ is assumed to have been from a fracture trending N10E-15EE that passed near ground zero. Also mentioned is a $140-\mathrm{ft}-(45-\mathrm{m}-)$ wide zone of fractures extending N10EE for about 1,600 ft $(490 \mathrm{~m}$ ) from U3bj (Entry 2). The authors recognize the test as having been in or very close to the Area 3 fault zone. "A seismic survey by the National Geophysical Company indicates not only the presence of the Area 3 fault at depth but another fault $1,300 \mathrm{ft}(400 \mathrm{~m})$ west of the $\mathrm{U} 3 \mathrm{bj}$ site . . . The seismic survey data, which seem valid, conflict with surface evidence of the direction of displacement on the Area 3 fault; about $5,000 \mathrm{ft}(1,524 \mathrm{~m})$ north of where the survey was conducted surface evidence shows that the west side of the fault is down. The seismic survey shows the east side down. This contradictory information suggests that perhaps more than one fault is involved. The direction of displacement along most faults does not change; change in direction, however, is not rare.

Because of the continuity of the fracturing along the Area 3 fault, we interpret it as one fault zone with changes in displacement along it."

The event at U3cy (PIKE, March 13, 1964; less than $20 \mathrm{kt}$ [DOE, 1994]) vented along an open fissure about $25 \mathrm{ft}(8 \mathrm{~m})$ long trending about N15EE, parallel to the Area 3 fault. U3cy is about $2,000 \mathrm{ft}(610 \mathrm{~m})$ from the Area 3 fault zone, which apparently was not affected. The event at U3bz (GRUNION; October 11, 1963; low yield [DOE, 1994]) and the event at U7y (TIJERAS; October 14, 1970; 20-200 kt [DOE, 1994]), both of which were contained, are discussed as analogs for the BANDICOOT event. U3bz (GRUNION) is about $750 \mathrm{ft}(230 \mathrm{~m})$ south of U3bj (BANDICOOT) and is also thought to be within the Area 3 fault zone. The TIJERAS event was detonated within a fracture zone caused by the Auk event (U7b). "Tijeras caused extension of the zone for a length of at least 5,000 feet $[1,524 \mathrm{~m}]$ to the southeast and displacements of as much as 12 in. $(9 \mathrm{~cm})$ down on the west side." The reasons that these events did not vent, while BANDICOOT and PIKE did, are not fully understood.

\section{Snyder, R. P., and Rogers, S., 1972, Explosion-induced surface fractures of selected announced underground nuclear tests, Yucca Flat, Nevada Test Site, Nevada, October 1969 through December 1970: U.S. Geological Survey Report NTS-231 (USGS-474-133), 57 p.}

The report discusses 17 underground nuclear tests conducted between October 29, 1969, and December 31, 1970, and maps the surface effects of these tests. Two tests affected the Area 3 fault: U7s (GRAPE [A]; December 17, 1969; 20-200 kt [DOE, 1994]) and U7y (TIJERAS) (Entry 32). GRAPE (A), located about 2,700 ft $(820 \mathrm{~m})$ east of the northern part of the Area 3 
fault zone, reactivated the Area 3 fault from 2,500 ft (760 m) west-southwest to 3,500 $\mathrm{ft}$ (1,070 $\mathrm{m})$ of ground zero; movement was both renewed and new.

The event at U7y (TIJERAS) reactivated the Area 3 fault, 1,300 to 1,400 ft (400 to $430 \mathrm{~m}$ ) west of ground zero, for a length of 4,600 ft (1402 m). Fracturing west of the Area 3 fault was restricted to a $400-\mathrm{ft}-(120-\mathrm{m}-)$ long pressure ridge $800 \mathrm{ft}(245 \mathrm{~m})$ west of the fault. East of the crater, a 1000 -ft- (305-m-)-wide zone of fractures fans out to the east. The zone may cross the crater to the west, where it appears as a single fracture that curves north into the Area 3 fault. The southern end of the zone of new fractures had an offset in one place of $8 \mathrm{in}$. $(20 \mathrm{~cm})$ down to the west. Offset of up to $9 \mathrm{in}$. $(23 \mathrm{~cm})$ down to the east occurred about $2,000 \mathrm{ft}(610 \mathrm{~m})$ north of this scarp. A prominent scarp trending southeast from ground zero was later named the $7 \mathrm{y}$ fault. The compilation map accompanying this report is the first to show a solid line (denoted as "fault showing explosion-induced movement" in the map legend) averaged through the Area 3 fault zone. A gap of about $1,000 \mathrm{ft}(305 \mathrm{~m})$ northeast of $\mathrm{U} 3 \mathrm{cq}$ was bridged by this line. The geophysically inferred faults were not included on this map, and Morris' lineaments (Entry 19) also were dropped except for one "cracked lineament." The designation of Morris' cracked lineament was changed to "fault showing explosion-induced movement," and the southern end of this lineament was shortened about 2,000 ft $(610 \mathrm{~m})$. A dashed line was then drawn from the new endpoint near U3fj through fractures probably from U3ez and/or U3gz to a northeasterly trending fracture zone near U3dg. The resulting line was named the East Branch Area 3 fault, and a short dashed line was added to connect this branch to the Area 3 fault trace.

\section{Steele, S. G and Snyder, R. P., 1973, Explosion-induced fractures of selected announced underground tests, Yucca Flat, Nevada Test Site, Nevada, January through December 1972: U.S. Geological Survey Report NTS-245 (USGS-474-176), 38 p.}

During the time period covered by this report, the event at U3jq (MONERO, May 19, 1972, less than $20 \mathrm{kt}$ [DOE, 1994]), was the only test near the Area 3 fault. MONERO ground zero is located about 1,250 ft ( $380 \mathrm{~m})$ east of the East Branch Area 3 fault. This event reactivated the $7 \mathrm{y}$ fault, but did not affect the Area 3 fault or the East Branch Area 3 fault. A map of explosioninduced features accompanying this report shows the same forked trace of the Area 3 fault and East Branch Area 3 fault as in USGS-133 (NTS-231) (Entry 29).

\section{Carr, W. J., 1974, Summary of tectonic and structural evidence for stress orientation at the Nevada Test Site: U.S. Geological Survey Open-file Report 74-176, 53 p.}

The general structural character of Yucca Flat is interpreted using multiple lines of evidence. In reference to the trough bounded on the west side by the Yucca fault, "Several west-dipping faults, such as the Area 3 fault, form the east walls of the medial trough, but basically the east side of the trough is a downwarp." "The Tertiary rocks dip westward into the basin from outcrops along the east side of the valley. Dips and strikes obtained from scattered drill holes in Areas 3 and 6 indicate that a westward dip in the tuffs persists into the main deep trough east of the Carpetbag fault zone." This information should be considered when interpreting drill hole data because a westward dip on a surface between two drill holes may be indistinguishable from a down-dropping of the surface to the west. 


\section{Seisdata Services, Inc., 1980, Los Alamos Scientific Lab seismic lines, Seisdata Services, Inc., unpaginated.}

Data from six seismic lines run by Seisdata for Los Alamos Scientific Lab in 1980 were located. Lines 6 and 2 are within the area of interest to this study. An accompanying interpretive report has not been located.

\section{Ferguson, J. F., 1981, Geophysical investigations of Yucca Flat: Dallas, Southern Methodist University, Ph.D. Dissertation, 110 p.}

Three seismic lines were recorded by Ferguson and Western Geophysical in 1978. One of these, Line E-3, runs east to west across Yucca Flat roughly $1.0 \mathrm{~m}(0.6 \mathrm{~km})$ south of the Area 3 RWMS. Interpretation of data was aided by gravity and borehole data. The Area 3 fault is not specifically mentioned; however, several faults are shown in the general area south of the mapped traces. "West-dipping faults on the eastern end of the seismic lines have steep dips, on the order of 70 degrees, and are conjugate to the basin forming faults." In contrast, Ferguson interprets the Carpetbag and Yucca faults to be shallow-dipping (45E to 60E) faults with a combination of right-lateral and dip slip. The interpretation of the faults in the eastern basin as west-dipping (suggesting west sides down if they are normal faults) is in contrast to the National Geophysical Company's conclusion that the Area 3 and other faults in this area are down to the east.

38. Dockery-Ander, H. A., 1984, Rotation of Late Cenozoic extensional stresses, Yucca Flat region, Nevada Test Site, Nevada: Houston, Rice University, Ph.D. Dissertation, 77 p.

The report does not specifically mention the Area 3 fault, although the trace is superimposed on the accompanying isopach and structure contour maps. Dockery used "... data from more than 300 drill holes ... to construct isopach and structure contour maps of major Tertiary and Quaternary units ..." and found "... no evidence ... for the presence of major faults other than the Yucca and Carpetbag."

39. App, F. N., 1985, Permanent displacement of the ground surface resulting from underground-nuclear-test-induced ground shock, in Olson, C.W. and Donohoe, M.L., (eds.), Proceedings of the Third Symposium on Containment of Underground Nuclear Explosions, v. 2: Idaho Falls, ID, U.S. Department of Energy, p. 409-425.

The surface effects of four events, including the event at U7bd (PALIZA; October 1, 1981; 20$150 \mathrm{kt}$ [DOE, 1994]), were studied in detail with the aid of surveyed level lines. Site U7bd is located approximately $500 \mathrm{ft}(150 \mathrm{~m})$ east of the northern part of the Area 3 fault and about the same distance to the west of the U7y fault. Offsets of up to $5 \mathrm{in} .(10 \mathrm{~cm})$, down to the west, were observed where crack mapping had indicated no fractures. Upon closer inspection, minor cracking was discovered at the sites of the measured offsets, but no cracking was seen at a third site where the level line had been offset by $2.5 \mathrm{in} .(6.4 \mathrm{~cm})$. App concludes that "... standard crack mapping does not always pick up indications of fault motion at the surface." This study also provided evidence that a large structural block between the Area 3 fault and another fault near the east end of the line was rotated to the east. A surface effects map was not included with this report. 


\section{Drellack, S. L., Jr., 1994, Structure contour map of the top of the Rainier Mesa Tuff in LANL use areas, Yucca Flat, NTS, revision 3: LANL Geologic Support Group Map TMRSC1.DGN, scale: 1:24,000.}

This map is one of a series of structure contour maps on various stratigraphic surfaces. This map is based on a complete and current set of borehole data. The subsurface fault is interpreted as having the shape of the surface trace (as defined by the persistent trend of shot-induced surface fractures) and is offset to the west by an amount based on depth to the contoured horizon and an assumed dip. This interpretation fits the subsurface drill hole data, although there are relatively few data points near the southern end of the Area 3 fault where it approaches the Area 3 RWMS. Two data points, however, may provide evidence of offset of the top of the Rainier Mesa Tuff of the Timber Mountain Group. Roughly 3,000 ft $(915 \mathrm{~m})$ north of the Area 3 RWMS, drill holes U3cs and U3kx show elevations of the top of the Timber Mountain Tuff of 3,183 and 2,900 ft $(972$ and $885 \mathrm{~m})$, respectively. This is an offset of $287 \mathrm{ft}(83 \mathrm{~m})$ in a lateral distance of less than $1,250 \mathrm{ft}(380 \mathrm{~m})$. The offset can be explained by faulting down to the west or by a surface dipping about 13EW. Tertiary rocks in outcrops roughly $2 \mathrm{mi}(3 \mathrm{~km})$ to the east dip 5 to $15 \mathrm{EW}$.

\section{USGS, 1990, Surface effects compilation map: Unpublished compilation map, scale $1: 12,000$.}

An unpublished compilation map has been maintained by the U.S. Geological Survey. This map shows the fractures associated with post-1975 events in addition to previously mapped fractures. Near the Area 3 fault, the map shows a collapse sink and minor fracturing associated with the event at U3kx (CANFIELD; May 2, 1980; less than $20 \mathrm{kt}$ [DOE, 1994]), just southeast of BILBY (U3cn), but fracture patterns on the segment of the Area 3 fault nearby appear unchanged from previous published maps. Near the northern part of the Area 3 fault, two collapse sinks are shown on this unpublished map which postdate previous mapping. These are U7bd (Entry 39) and U7bp (ATRISCO; August 5, 1982; $138 \mathrm{kt}$ [DOE, 1994]). These events have added more fractures to the adjacent Area 3 fault without extending it farther north. 


\section{REFERENCES}

Chase, L., 1965. Revised isopach map of alluvium in Yucca Flat, Nevada Test Site: U.S. Geological Survey Technical Paper NTS-136, 1 p., 1 map sheet, scale 1:48,000.

Dixon, G. L., Sargent, K.A., and Spengler, R.W., 1973. Lithologic logs of exploratory and emplacement holes in Area 3, Nevada Test Site: U.S. Geological Survey Report NTS-244 (USGS-474-151), $138 \mathrm{p}$.

DOE, 1994. United States nuclear tests July 1945 through September 1992: Department of Energy Report DOE/NV-209 (Rev. 14), paginated by section.

Drellack, S. L., Jr., and Thompson, P.H., 1990. Selected Stratigraphic data for drill holes in LANL use areas of Yucca Flat: Department of Energy Report DOE/NV/10322-39, 192 p. 


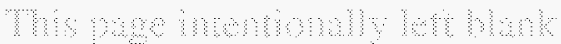




\section{APPENDIX B TRENCH WALL MAPS}


Ths mes intentondy len brum 


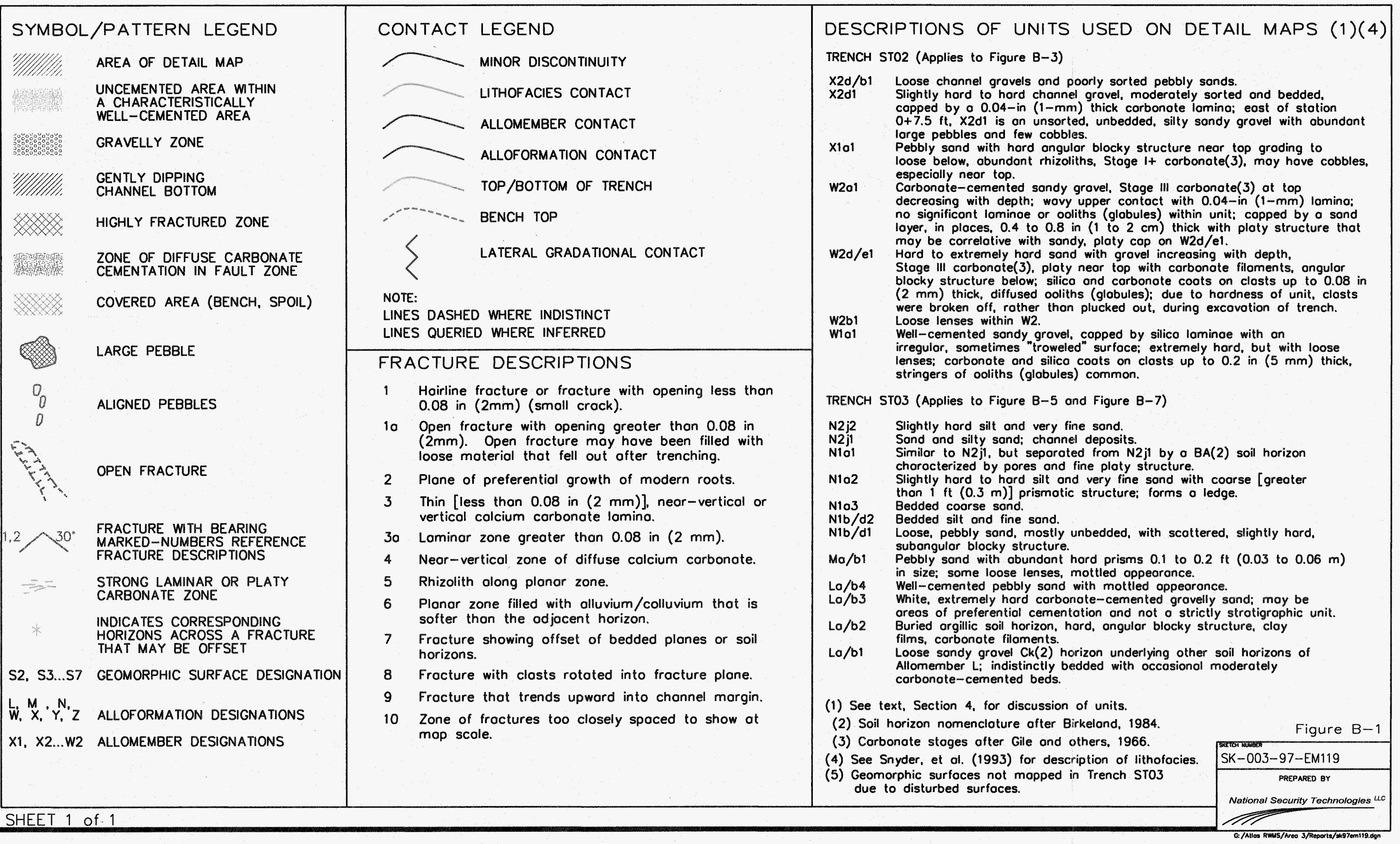




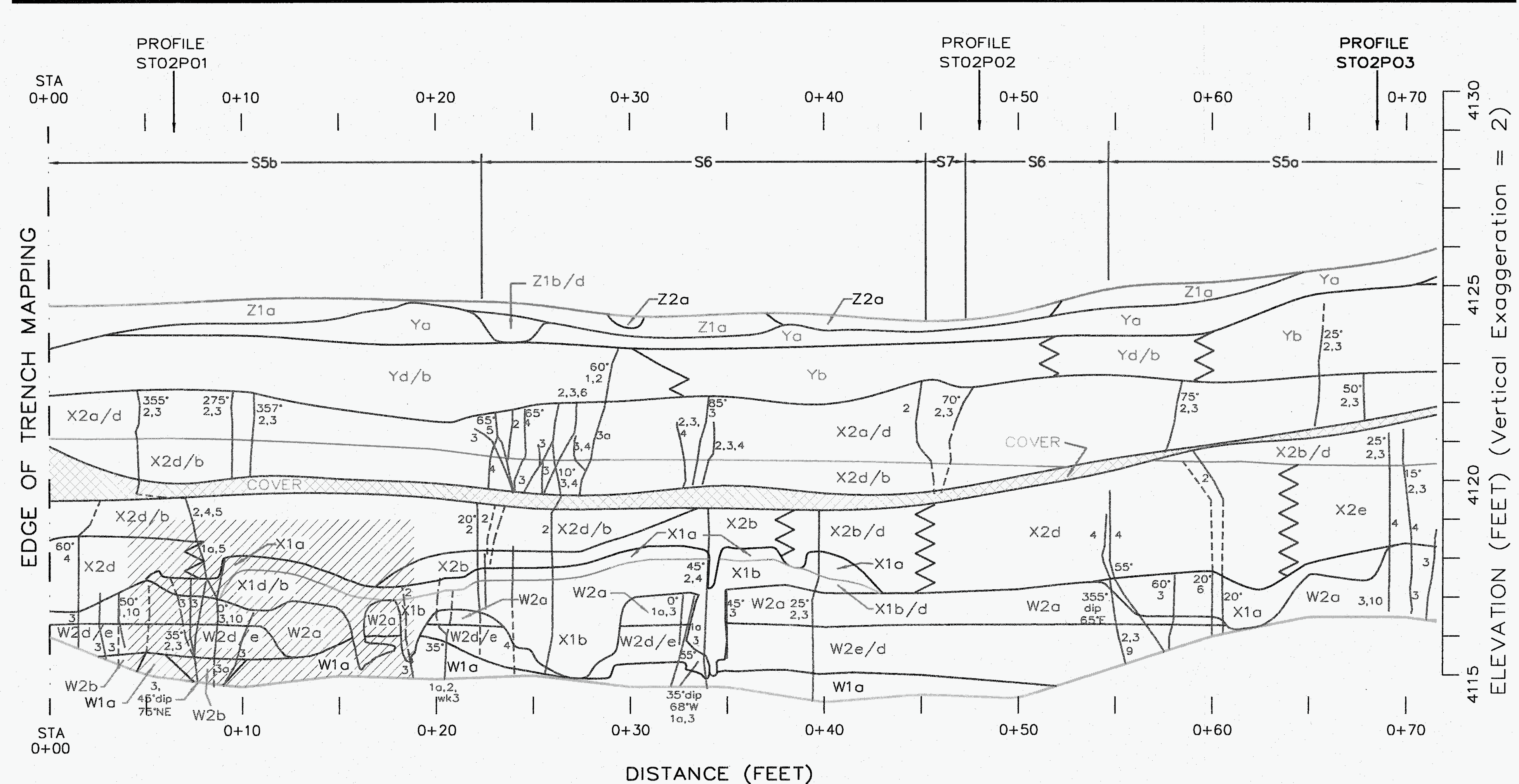

Figure $B-20$

STRATIGRAPHY AND GEOMORPHIC SURFACES OF NORTH WALL SHEET 1 of 4 IN SOIL TRENCH TWO (STO2) SOUTHEASTERN YUCCA FLAT 


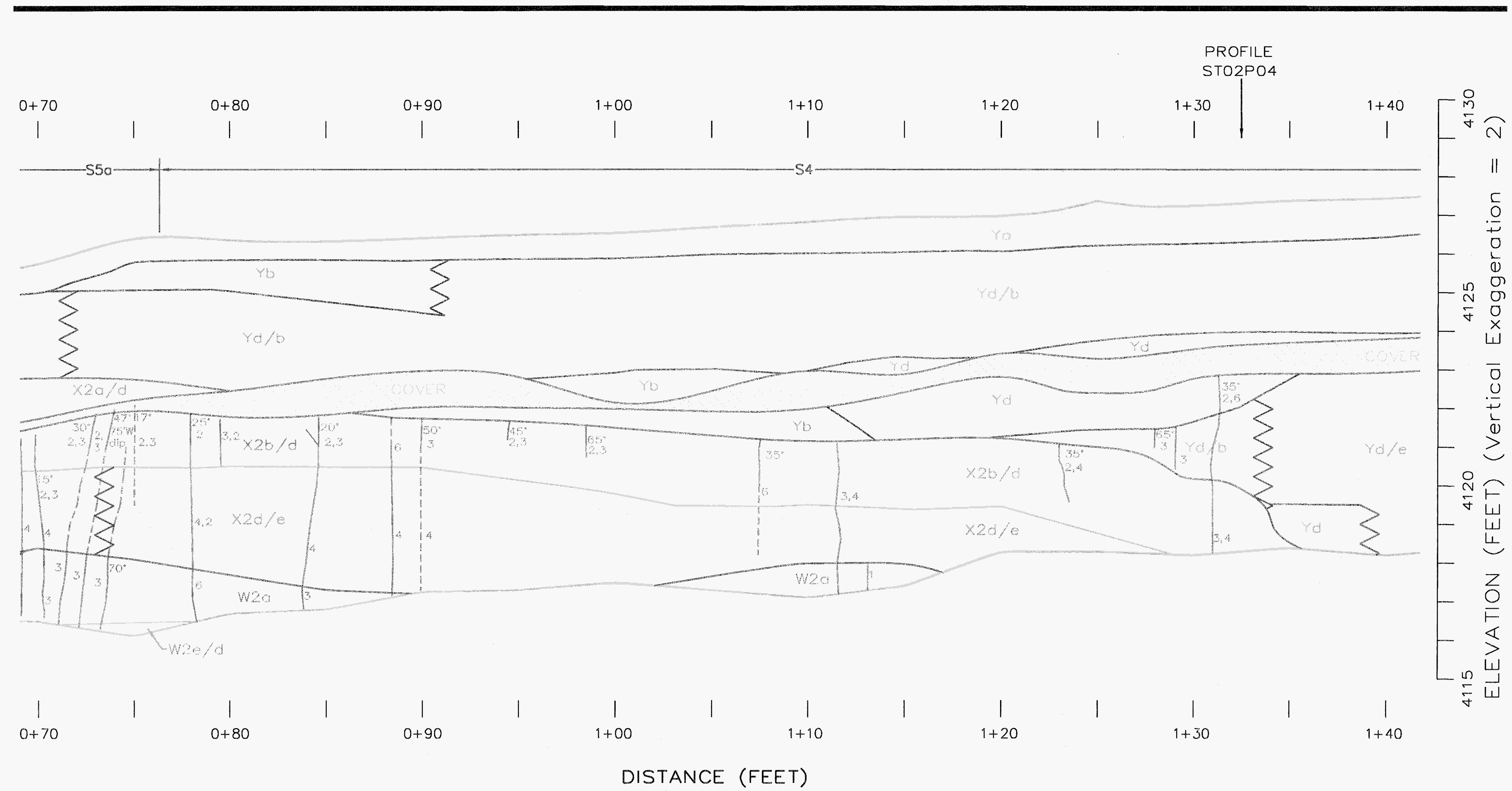

Figure $B-2 b$

STRATIGRAPHY AND GEOMORPHIC SURFACES OF NORTH WALL SHEET 2 of 4 IN SOIL TRENCH TWO (STO2) SOUTHEASTERN YUCCA FLAT 


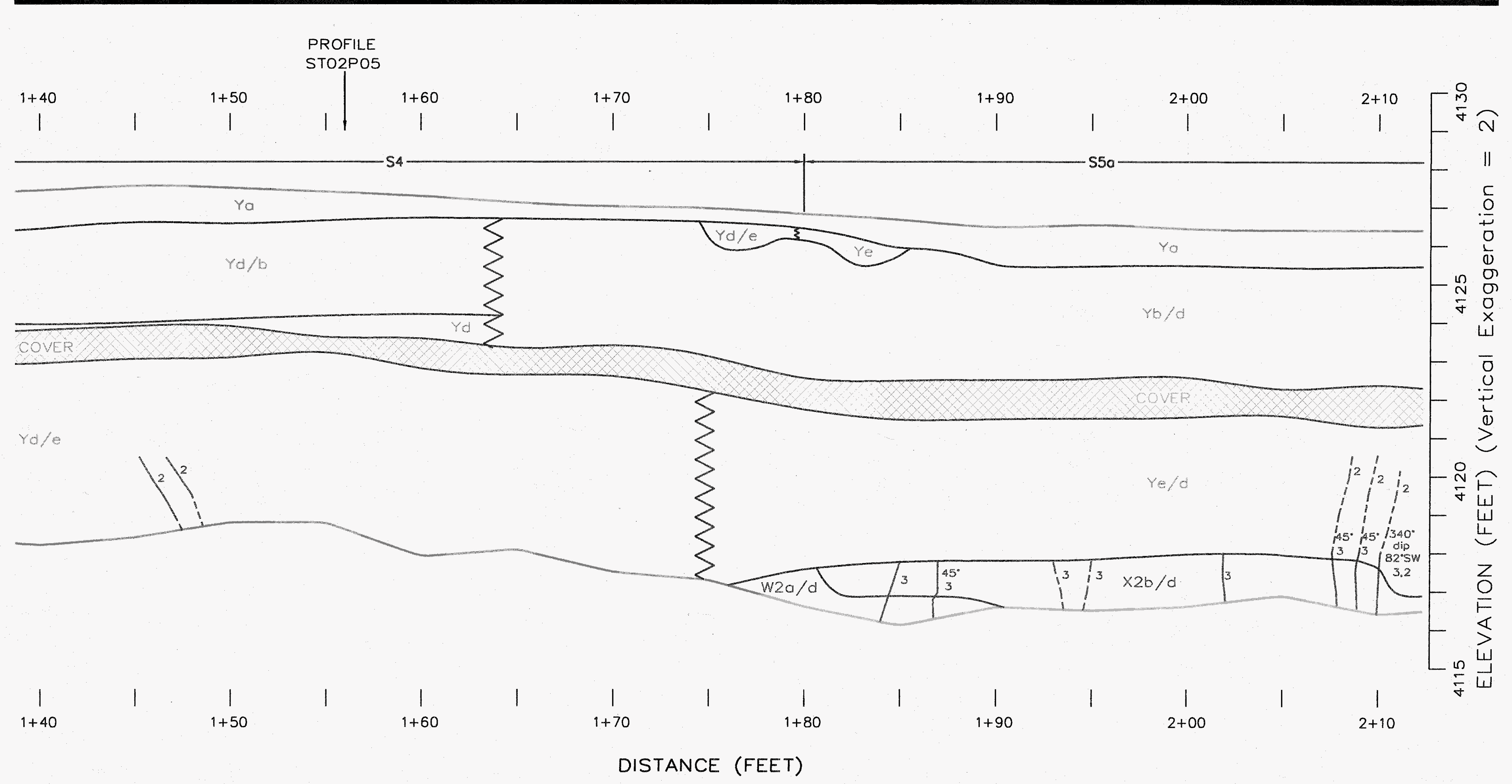
STRATIGRAPHY AND GEOMORPHIC SURFACES OF NORTH WALL IN SOIL TRENCH TWO (STO2) SOUTHEASTERN YUCCA FLAT
Figure $B-2 c$ 


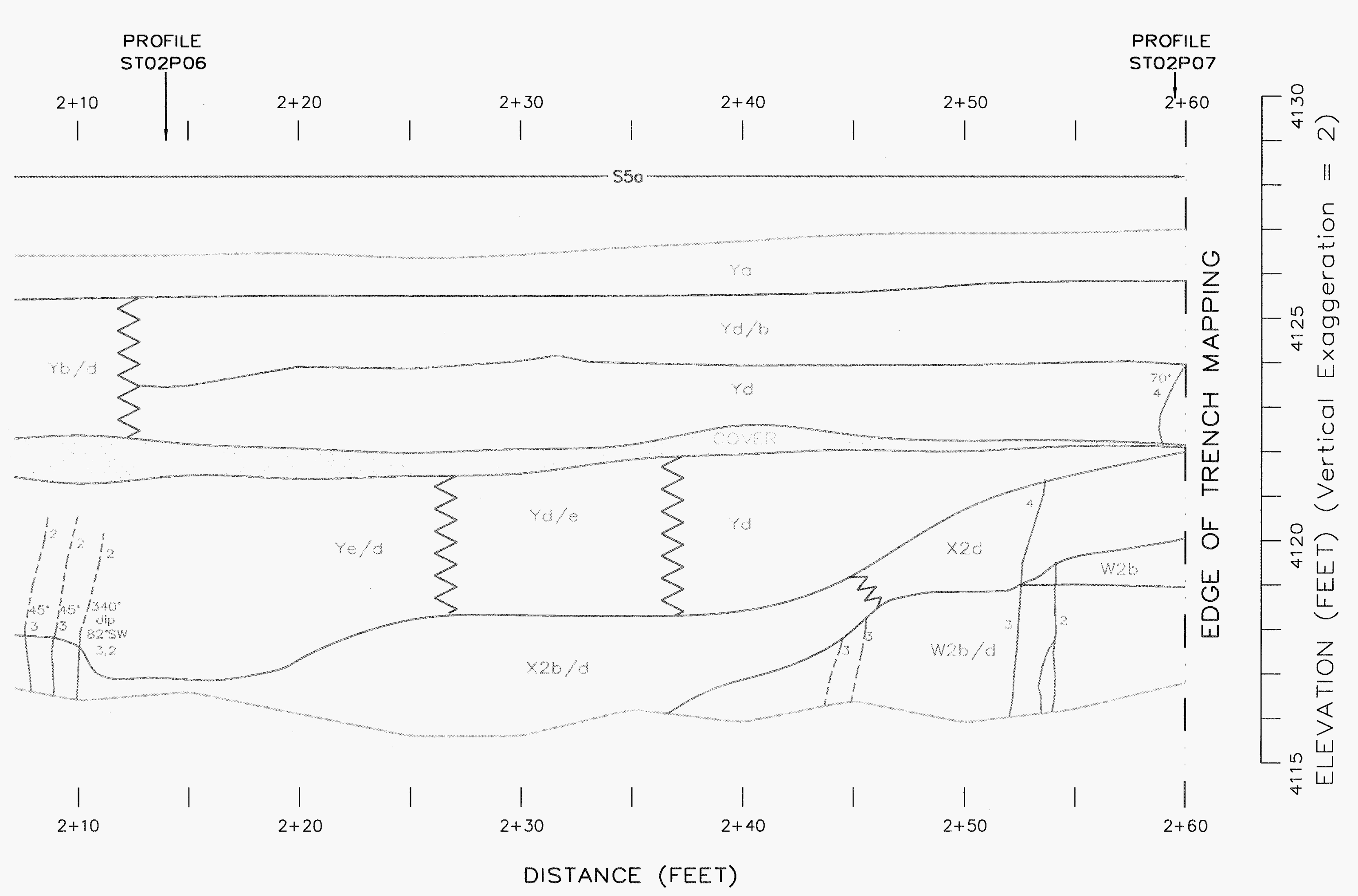

Figure $B-2 d$

STRATIGRAPHY AND GEOMORPHIC SURFACES OF NORTH WALL IN SOIL TRENCH TWO (STO2) SOUTHEASTERN YUCCA FLAT 


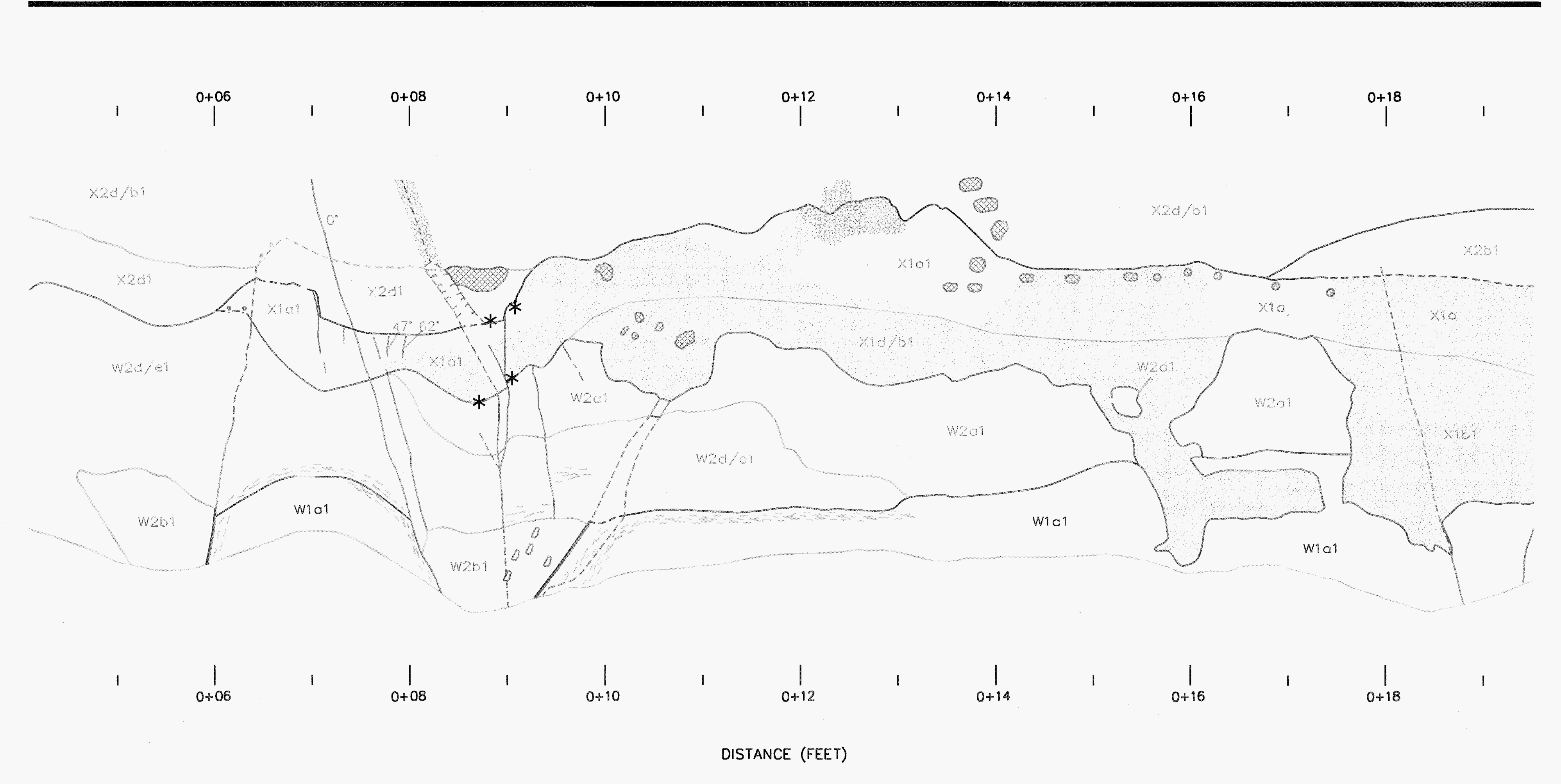
SCALE: 1 inch $=1$ loot

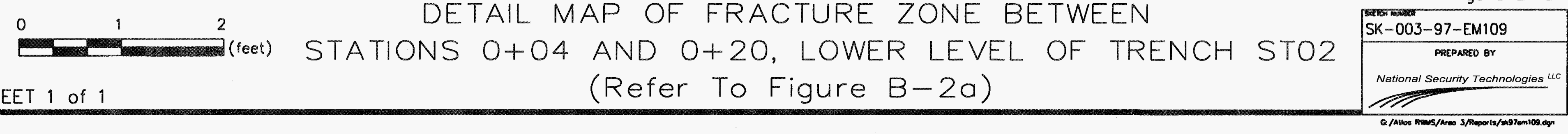

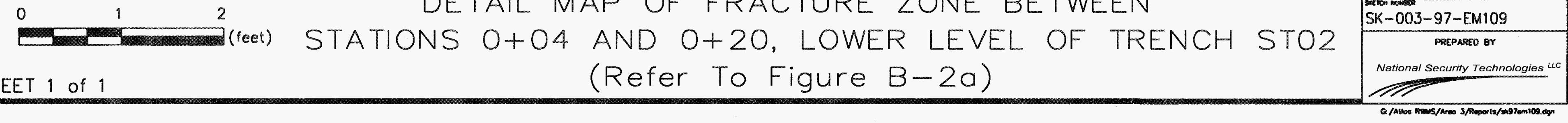

DETAIL MAP OF FRACTURE ZONE BETWEEN

Figure $B-3$ 


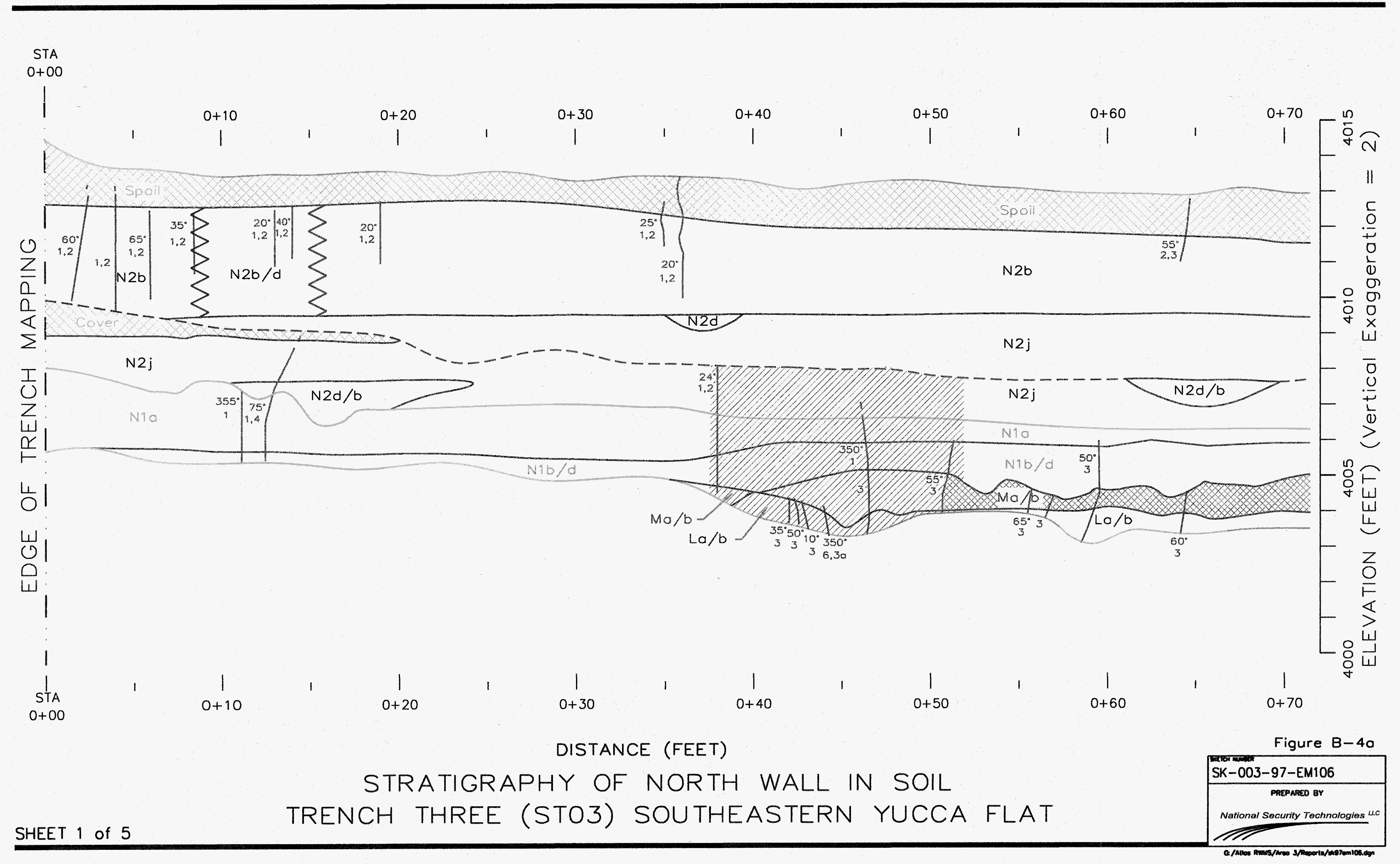




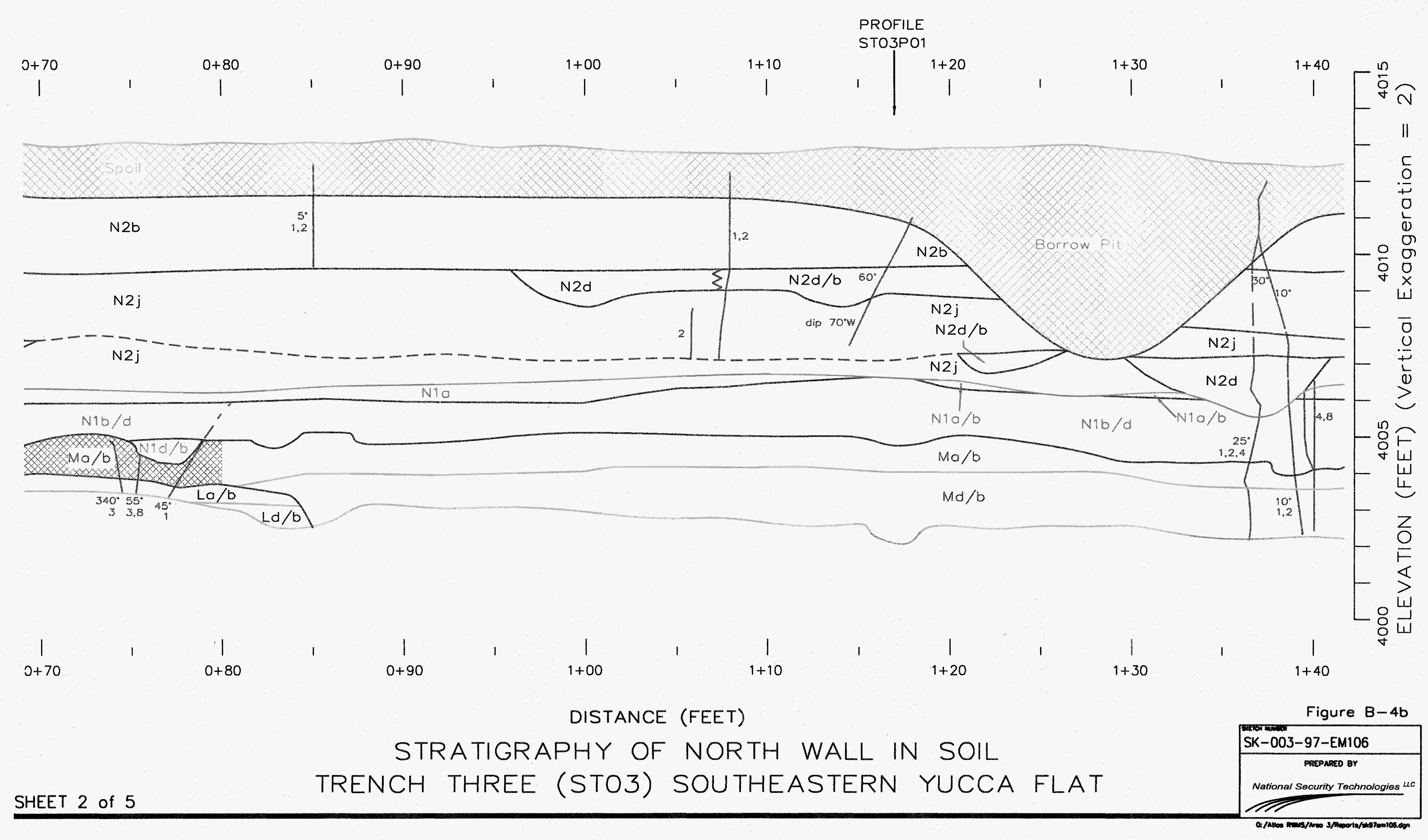




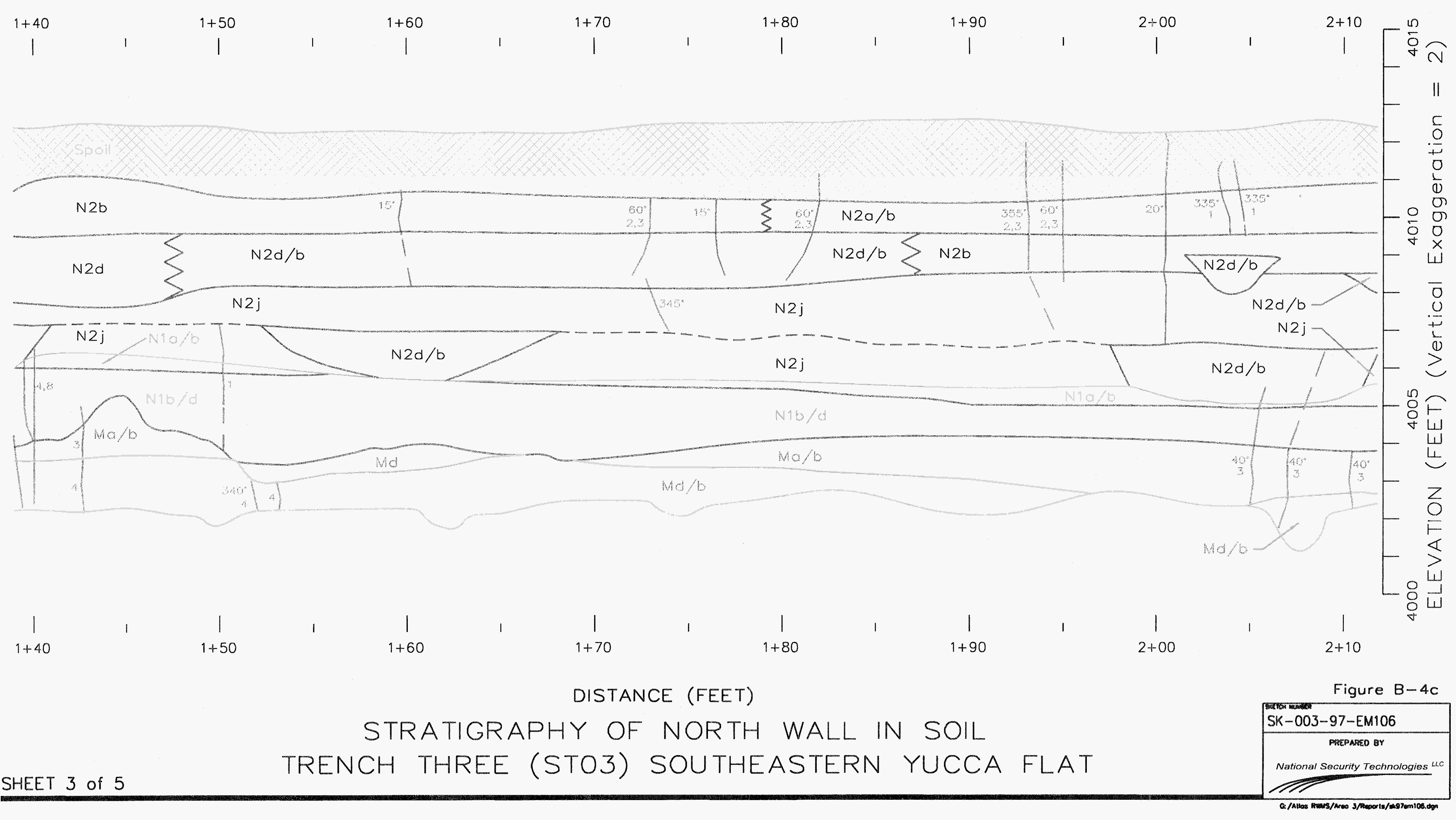




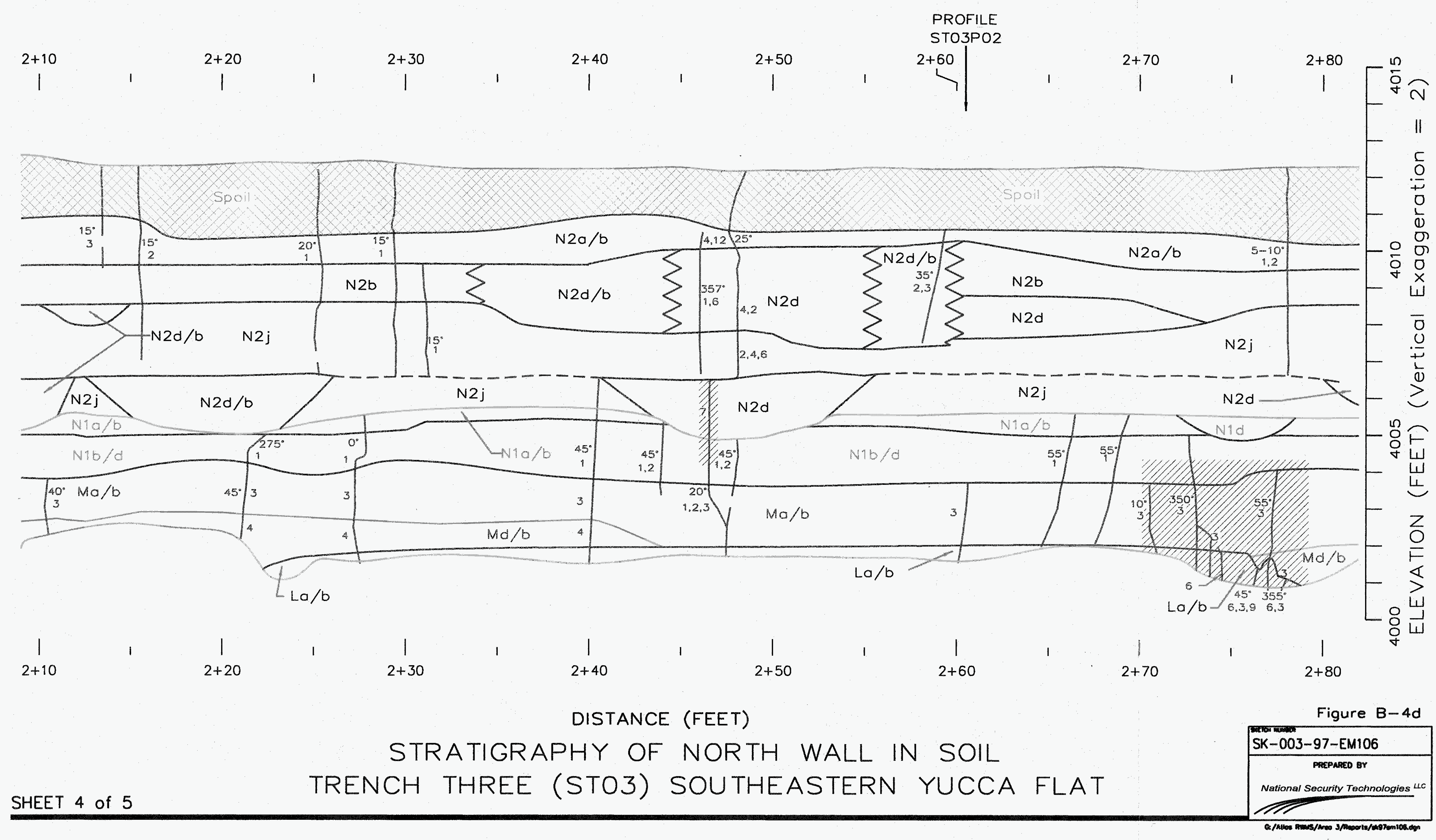




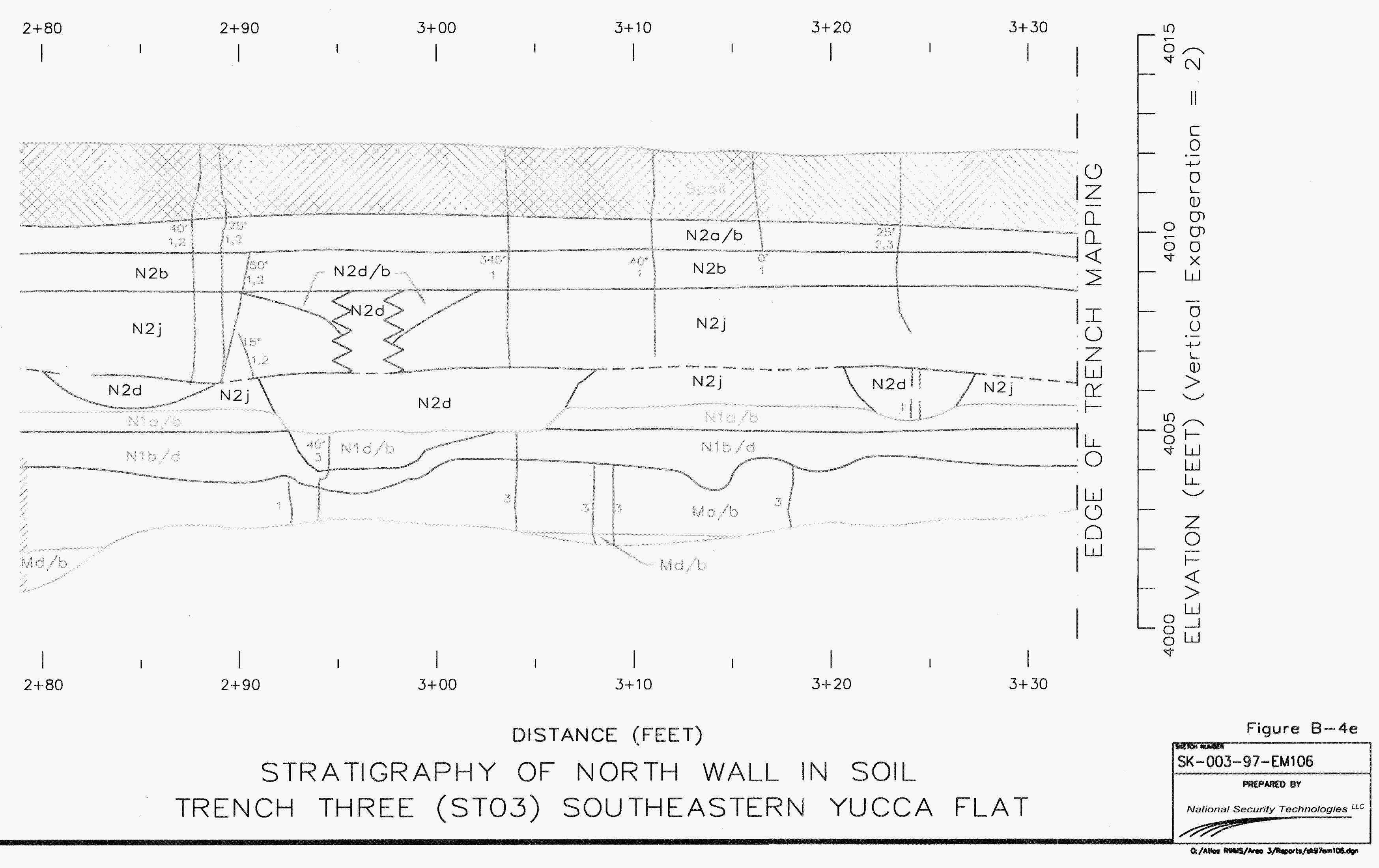




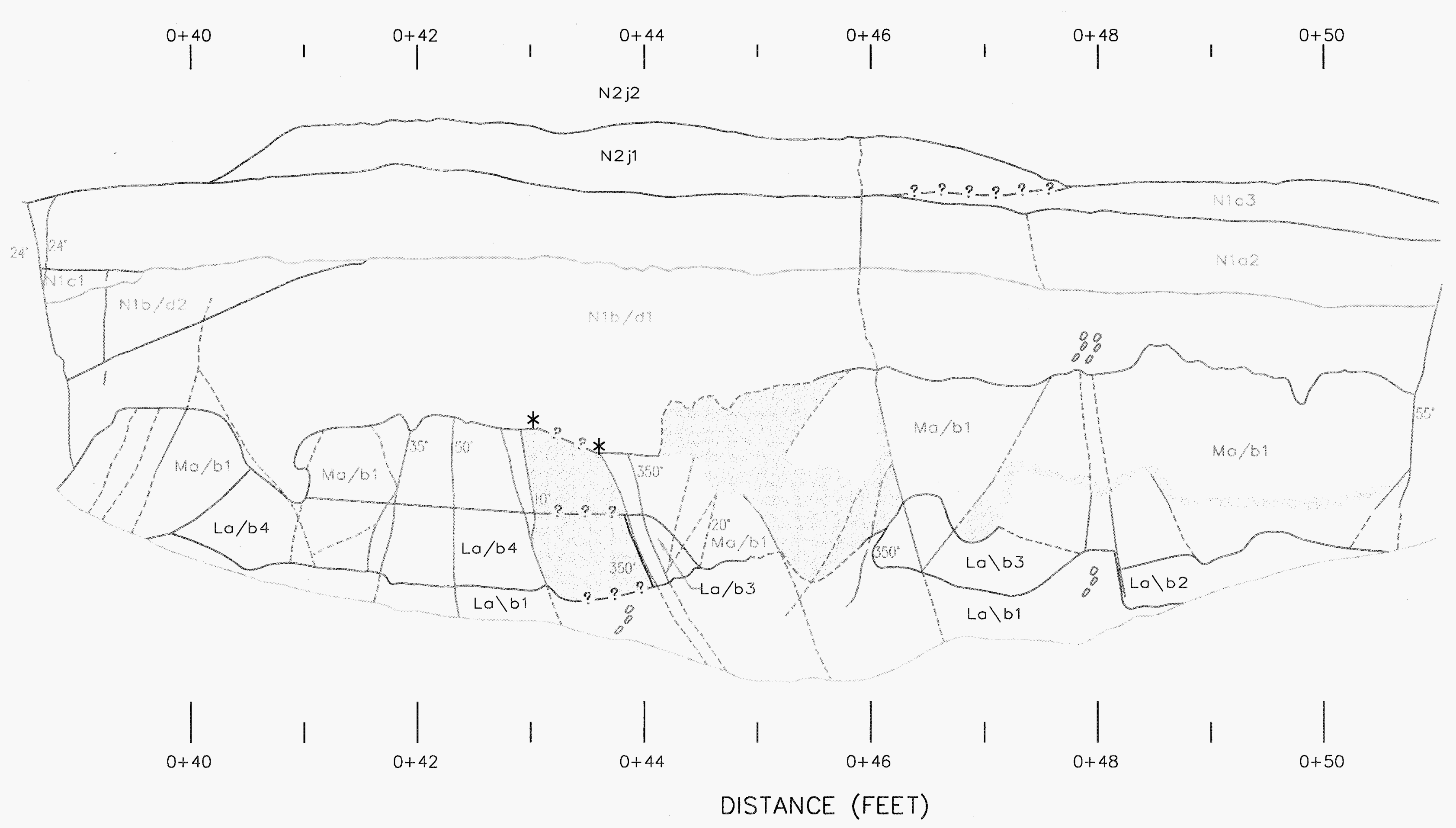

SCALE: 1 inch $=11001$

0

DETAIL MAP OF FRACTURE ZONE BETWEEN

Figure $B-5$ (feet) STATIONS O+40 AND O+5O, LOWER LEVEL OF TRENCH STO3 


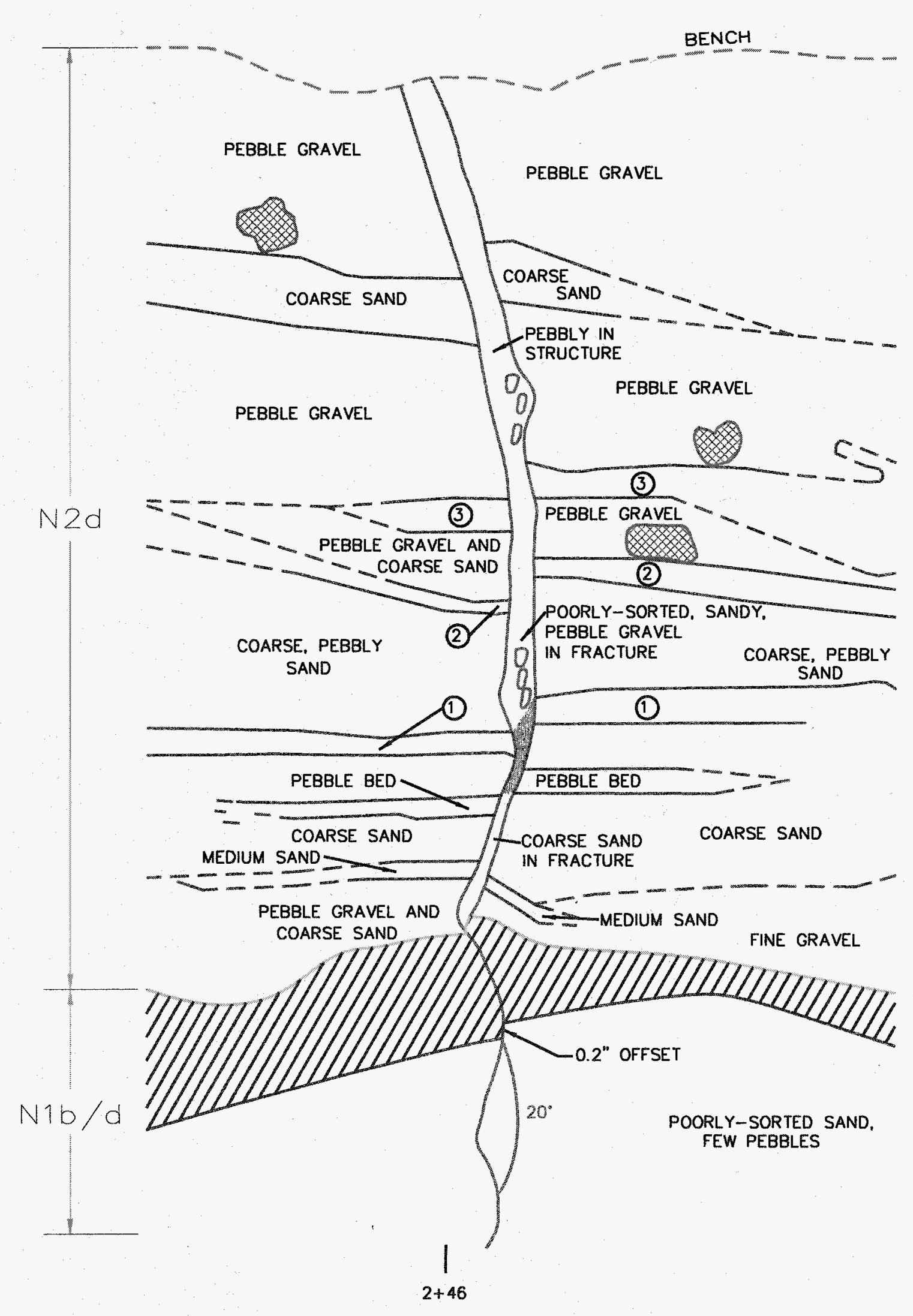

SHEET 1 of 1
(1) SILTY BED, 0.4 - 0.6 INCHES THICK. HORIZONTAL WHITE RHIZOLITHS AT OR NEAR BASE. ABRUPT TOP. ABRUPT BASE OVERLIES 0.6 INCHES LAYER OF MEDIUM, MODERATELY-SORTED SAND, OFFSET MEASURED AT 0.6 INCHES, DOWN TO WEST.

(2) SLIGHTLY MORE RESISTANT, MODERATELY WELL-SORTED MEDIUM SAND BED, 0.4 INCHES THICK. OFFSET MEASURED AT 0.6 INCHES DOWN TO WEST. FRACTURE ZONE IS 0.5 INCHES WDE.

(3) OFFSET MEASURED AT 0.5 INCHES DOWN TO WEST. FRACTURE ZONE IS 0.4 INCHES WIDE. BED IS 0.4 INCHES THICK.

DETAIL OF FRACTURE OFFSETTING BEDS NEAR STATION 2+46 OF TRENCH STO3
SCALE: 1 inch $=0.2$ reel

$\begin{array}{lll}0 & 0.2 & 0.4\end{array}$

Figure $B-6$

\begin{tabular}{|c|}
\hline SK-003-97-EM108 \\
\hline PREPNED BY \\
National Security Technologies LC \\
\hline
\end{tabular}




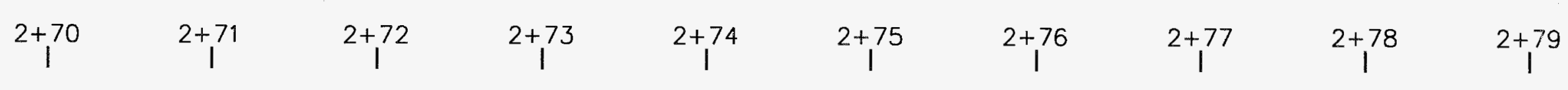

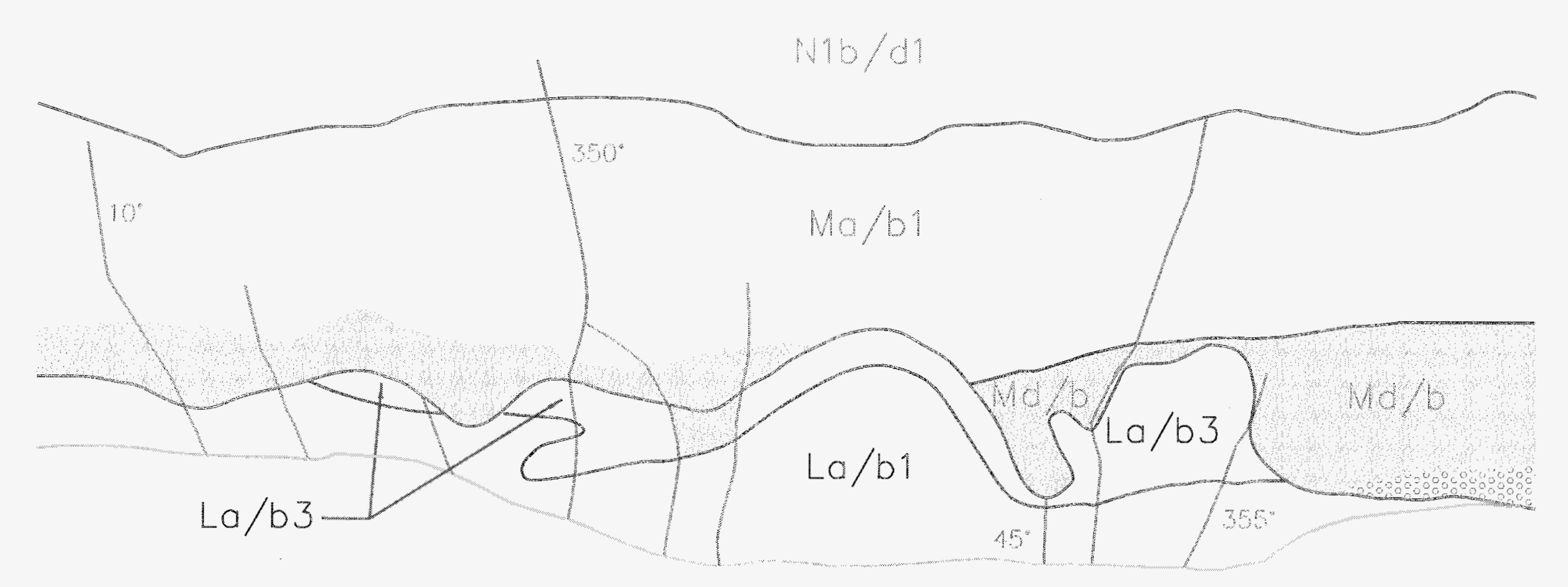

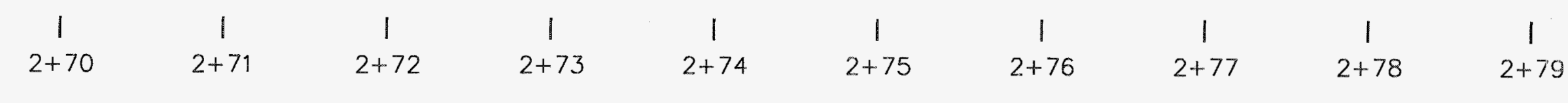




\section{APPENDIX C SOIL PROFILE DESCRIPTIONS}




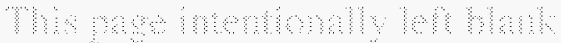


Appendix $\mathrm{C}$ includes descriptions of 24 soil excavations and trenches that were dug in order to understand the subsurface geology at or near the Area 3 RWMS. Descriptions included are as follows:

- Nine soil excavations are described (EX01-P01 through EX09-P01) that were hand-dug throughout the general area, and which represent geomorphic surfaces.

- Soil Trench 1 (ST01) includes six soil profiles (ST01-P01 through ST01-P06) that describe the soils only. This trench was not dug for fault evidence and was not mapped.

- Soil Trench 2 (ST02) includes seven profiles (ST02-P01 through ST02-P07). This trench was dug not only to describe soils, but to seek evidence for the existence of the Area 3 fault.

- Soil Trench 3 (ST03) includes two profiles (ST03-P01 through ST03-P03). This trench was dug not only to describe soils, but to seek evidence for the existence of the Area 3 fault. 


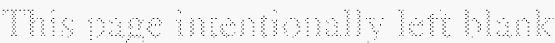




\section{SOIL EXCAVATIONS EX01-P01 THROUGH EX09-P01}

\section{SOIL PROFILE EX01-P01}

Location: Excavation at ground level, approximately 1.2 mile $(1.9 \mathrm{~km})$ northeast of NTS Area 3 RWMS; Nevada State Plane coordinates 843670 feet north and 688733 feet east; 4115 feet (1254 meters) elevation.

Described by: R. D. Van Remortel and K. E. Snyder

Sampled by: R. D. Van Remortel

Date described / sampled: 2 May 1996/21 May 1996

Geomorphic surface: S5a or S4*

Taxonomic classification of uppermost deposit: Haplargid (in Unit *)

Taxonomic classification of pedon: Coarse-loamy, mixed, thermic Typic Haplargids

Remarks: Matrix colors are for crushed and smoothed hand samples, while colors of surface features and concentrations are for undisturbed samples. All colors are for dry conditions unless noted otherwise. The textures given are field-determined.

\section{DESCRIPTION}

A1 0 to 1.2 in. (0 to $3 \mathrm{~cm})$. Light gray (10YR7/2) gravelly loamy sand, dark yellowish-brown (10YR4/4) moist; moderate thin platy structure parting to weak fine granular; soft, very friable, nonsticky and nonplastic; few fine roots; common coarse vesicular pores; few thin paleocarbonate coatings on sides of rock fragments; 5 percent cobbles and 15 percent pebbles from mixed pyroclastic and calcareous sedimentary rocks; abrupt wavy boundary. (Unit * and sample a01a)

A2 1.2 to 2.8 in. ( 3 to $7 \mathrm{~cm}$ ). Light yellowish-brown (10YR6/4) sandy loam, dark yellowish-brown (10YR4/6) moist; moderate thin platy structure; slightly hard, friable, slightly sticky and slightly plastic; few very fine roots; common coarse vesicular pores; few thin paleocarbonate coatings on sides of rock fragments; 2 percent pebbles from mixed pyroclastic and calcareous sedimentary rocks; abrupt wavy boundary. (Unit * and sample a01b) 
BA 2.8 to 8.3 in. (7 to $21 \mathrm{~cm})$. Pink ( 7.5 YR7/3) sandy loam, brown $(7.5 Y$ R5/4) moist; moderate coarse prismatic structure, parting to moderate thick platy; slightly hard, friable, slightly sticky and slightly plastic; few very fine roots; few fine and medium vesicular pores; very few thin argillans lining pores and on contacts between fine pebbles and ped surfaces; Stage I- carbonate development; very few very fine carbonate masses and very few thin carbonate coatings lining pores and old root channels; 2 percent pebbles from mixed pyroclastic and calcareous sedimentary rocks; clear wavy boundary. (Unit * and sample a02)

$2 B k$

2Btkb 8.3 to 13.4 in. (21 to $34 \mathrm{~cm}$ ). Pink (7.5YR7/3) sandy loam, brown (7.5YR5/4) moist; weak medium subangular blocky structure; soft, very friable, slightly sticky and slightly plastic; few very fine roots; few fine vesicular pores; very few thin argillans lining pores and old root channels; Stage I carbonate development; few thin carbonate coatings lining pores, old root channels, and undersides of rock fragments; 5 percent pebbles from mixed pyroclastic and calcareous sedimentary rocks; abrupt wavy boundary. (Unit * and sample a03)

13.4 to 16.5 in. (34 to $42 \mathrm{~cm}$ ). Pink (7.5YR7/3) sandy loam, reddish-yellow (7.5YR6/6) moist; moderate medium subangular blocky structure; slightly hard, friable, slightly sticky and plastic; few very fine roots; few fine vesicular pores; few thin argillans lining pores and on contacts between fine pebbles and ped surfaces; Stage I+ carbonate development; common thin carbonate coatings lining pores, old root channels, and undersides of rock fragments; 10 percent pebbles from mixed pyroclastic and calcareous sedimentary rocks; clear wavy boundary. (Unit * and sample a04)

2Bkb $\quad 16.5$ to 23.6 in. (42 to $60 \mathrm{~cm}$ ). Pink (7.5YR7/3) sandy loam, brown (7.5YR4/4) moist; weak fine subangular blocky structure; soft, very friable, slightly sticky and slightly plastic; few very fine roots; Stage I carbonate development; few very thin carbonate coatings lining pores, old root channels, and undersides of rock fragments; 12 percent pebbles from mixed pyroclastic and calcareous sedimentary rocks. (Unit* and sample a05)

NOTES: Location was determined from a 1:48,000 base map and is accurate to within $50 \mathrm{ft}$ $(15 \mathrm{~m})$. Elevation was determined from a 1:48,000 base map and is accurate to within $5 \mathrm{ft}$ $(1.5 \mathrm{~m})$. Diagnostic features include an ochric epipedon 0 to $2.7 \mathrm{in}$. $(0$ to $7 \mathrm{~cm}$ ) and argillic horizon 13.4 to $16.5 \mathrm{in}$. ( 34 to $42 \mathrm{~cm}$ ). The thickness of the eolian mantle in this pedon is $8.2 \mathrm{in}$. (*21 cm), including $2.7 \mathrm{in}$. $(7 \mathrm{~cm}$ ) of local sandy eolian material capping the soil surface. The argillic horizon contains 3 percent or more clay than the original $\mathrm{C}$ horizon parent material is presumed to have contained. 


\section{SOIL PROFILE EX02-P01}

Location: Excavation at ground level, approximately 1.2 mile $(1.9 \mathrm{~km})$ northeast of NTS Area 3 RWMS; Nevada State Plane coordinates 843918 feet north and 688461 feet east; 4115 feet (1254 meters) elevation.

Described by: R. D. Van Remortel and K. E. Snyder

Sampled by: R. D. Van Remortel

Date described / sampled: 2 May 1996 / 21 May 1996

Geomorphic surface: S5a

Taxonomic classification of uppermost deposit: Haplocambid (in Unit *)

Taxonomic classification of pedon: Sandy-skeletal, mixed, thermic Typic Haplocambids

Remarks: Matrix colors are for crushed and smoothed hand samples, while colors of surface features and concentrations are for undisturbed samples. All colors are for dry conditions unless noted otherwise. The textures given are field-determined.

\section{DESCRIPTION}

A

0 to 3.5 in. ( 0 to $9 \mathrm{~cm}$ ). Pale brown (10YR6/3) gravelly loamy sand, dark brown (10YR4/3) moist; weak thin platy structure parting to weak fine granular; soft, very friable, nonsticky and nonplastic; common fine roots; few thin paleocarbonate coatings on sides of rock fragments; 30 percent pebbles from mixed pyroclastic and calcareous sedimentary rocks; abrupt wavy boundary. (Unit * and sample a01)

BA $\quad 3.5$ to 9.8 in. (9 to $25 \mathrm{~cm})$. Very pale brown (10YR7/3) gravelly sand, dark yellowish-brown (10YR4/4) moist; weak medium prismatic structure parting to weak thin platy and weak coarse subangular blocky; soft, very friable, nonsticky and nonplastic; few fine roots; few thin paleocarbonate coatings on sides of rock fragments; 25 percent pebbles from mixed pyroclastic and calcareous sedimentary rocks; abrupt wavy boundary. (Unit * and sample a02)

Bk $\quad 9.8$ to 18.5 in. (25 to $47 \mathrm{~cm})$. Pink (7.5YR7/3) very gravelly sand, dark brown (7.5YR4/4) moist; weak medium subangular blocky structure; soft, very friable, nonsticky and nonplastic; few fine roots; Stage I carbonate development; few fine carbonate masses and common thin carbonate coatings on undersides of rock fragments; 45 percent pebbles from mixed pyroclastic and calcareous sedimentary rocks; clear wavy boundary. (Unit* and sample a03) 
BCk 18.5 to 23.6 in. (47 to $60 \mathrm{~cm})$. Pinkish-gray $(7.5 Y R 7 / 2)$ very gravelly coarse sand, light brown (7.5YR6/3) moist; weak fine subangular blocky structure with areas of very faint relict bedding; soft, very friable, nonsticky and nonplastic; few fine roots; Stage I carbonate development; few thin carbonate coatings on undersides of rock fragments; 45 percent pebbles from mixed pyroclastic and calcareous sedimentary rocks. (Unit * and sample a04)

NOTES: Location was determined from a 1:48,000 base map and is accurate to within $50 \mathrm{ft}$. $(15 \mathrm{~m})$. Elevation was determined from a 1:48,000 base map and is accurate to within $5 \mathrm{ft}$ $(1.5 \mathrm{~m})$. Diagnostic features include an ochric epipedon 0 to $3.5 \mathrm{in}$. (0 to $9 \mathrm{~cm})$ and cambic horizon 9.8 to $18.5 \mathrm{in.}$ (25 to $47 \mathrm{~cm}$ ). 


\section{SOIL PROFILE EX03-P01}

Location: Excavation along stream cut just east of powerline road, approximately 3 miles $(4.8 \mathrm{~km})$ east of NTS Area 3 RWMS; Nevada State Plane coordinates 838709 feet north and 700341 feet east; 4265 feet (1300 meters) elevation.

Described by: R. D. Van Remortel and K. E. Snyder

Sampled by: R. D. Van Remortel

Date described / sampled: 2 May 1996 / 20 May 1996

Geomorphic surface: S4

Taxonomic classification of uppermost deposit: Haplargid (in Unit *)

Taxonomic classification of pedon: Loamy-skeletal, mixed, thermic Typic Haplargids

Remarks: Matrix colors are for crushed and smoothed hand samples, while colors of surface features and concentrations are for undisturbed samples. All colors are for dry conditions unless noted otherwise. The textures given are field-determined.

\section{DESCRIPTION}

A

0 to $0.8 \mathrm{in}$. ( 0 to $2 \mathrm{~cm}$ ). Pale brown (10YR6/3) extremely gravelly very fine sandy loam, dark brown (10YR4/3) moist; weak thin platy structure parting to weak fine granular; soft, very friable, slightly sticky and slightly plastic; many fine vesicular pores; common thin paleocarbonate coatings on sides of rock fragments; common black cryptogams on soil surface; 5 percent cobbles and 75 percent pebbles from mixed calcareous sedimentary and pyroclastic rocks; abrupt wavy boundary. (Unit * and sample a01a)

BAq $\quad 0.8$ to 6.7 in. $(2$ to $17 \mathrm{~cm})$. Very pale brown $(10 \mathrm{YR} 7 / 3)$ gravelly loam, yellowishbrown (10YR5/6) moist; moderate coarse prismatic structure parting to strong medium platy; hard, firm, sticky and plastic; few fine roots; many medium and coarse vesicular pores; very few thin argillans lining old root channels; common thin silica coatings on undersides of rock fragments and structural plates; common thin paleocarbonate coatings on sides of rock fragments; 20 percent pebbles from mixed calcareous sedimentary and pyroclastic rocks; abrupt wavy boundary. (Unit * and sample a01b) 
2Btk 6.7 to $12.6 \mathrm{in}$. (17 to $32 \mathrm{~cm})$. Pink ( $7.5 Y$ R $7 / 3$ ) extremely gravelly sandy loam, strong brown (7.5YR5/6) moist; weak fine subangular blocky structure; soft, very friable, slightly sticky and slightly plastic; common fine and medium roots; few thin argillans on contacts between fine pebbles and ped surfaces; Stage I+ carbonate development; common thin carbonate coatings lining old root channels and common pinkish-white (7.5YR8/2) 5-mm carbonate pendants on undersides of rock fragments; 10 percent cobbles and 50 percent pebbles from mixed calcareous sedimentary and pyroclastic rocks; clear wavy boundary. (Unit* and sample a02)

2Bk1 12.6 to 23.6 in. (32 to $60 \mathrm{~cm}$ ). Pink (7.5YR7/3) very gravelly loamy sand, brown (7.5YR5/4) moist; weak fine subangular blocky structure; soft, very friable, nonsticky and nonplastic; common fine and medium roots; Stage I+ carbonate development; common thin carbonate coatings and common pinkish-white (7.5YR8/2) 3-mm pendants on undersides of rock fragments; 5 percent cobbles and 50 percent pebbles from mixed calcareous sedimentary and pyroclastic rocks; clear wavy boundary. (Unit* and sample a03)

2Bk2 23.6 to 34.2 in. (60 to $87 \mathrm{~cm})$. Pink (7.5YR7/3) extremely gravelly sandy loam, strong brown (7.5YR5/6) moist; weak medium subangular blocky structure; soft, very friable, nonsticky and nonplastic; common fine and medium roots; Stage I+ carbonate development; common thin carbonate coatings and common pink (7.5YR8/3) 5- to 8-mm pendants on undersides of rock fragments; 5 percent cobbles and 55 percent pebbles from mixed calcareous sedimentary and pyroclastic rocks; abrupt wavy boundary. (Unit* and sample a04)

3Btkmb $\quad 34.237 .4 \mathrm{in}$. (87 to $95 \mathrm{~cm})$. Red (2.5YR5/6) and pinkish-white (5YR8/2) extremely gravelly loamy sand, red (2.5YR4/6) and pink (5YR7/3) moist; strong medium subangular blocky structure; extremely hard, slightly rigid, nonsticky and nonplastic; common thin argillans on contacts between fine pebbles and ped surfaces; Stage III+ carbonate development; pink (7.5YR7/3, 6/3 moist) 2-mm carbonate lamina capping top of horizon; 90 percent strongly carbonate-cemented with many pinkish-white $(7.5 \mathrm{YR} 8 / 2)$ moderately thick carbonate pendants on undersides of rock fragments; 10 percent cobbles and 60 percent pebbles from mixed calcareous sedimentary and pyroclastic rocks. (Unit * and no sample collected)

NOTES: Location was determined from a 1:48,000 base map and is accurate to within $50 \mathrm{ft}$. $(15 \mathrm{~m})$. Elevation was determined from a 1:48,000 base map and is accurate to within $5 \mathrm{ft}$ $(1.5 \mathrm{~m})$. Diagnostic features include an ochric epipedon 0 to $.8 \mathrm{in}$. $(0$ to $2 \mathrm{~cm})$ and argillic horizon 6.7 to $12.6 \mathrm{in}$. (17 to $32 \mathrm{~cm}$ ). The thickness of the eolian mantle in this pedon is $6.7 \mathrm{in}$. $(17 \mathrm{~cm})$. The argillic horizon contains 3 percent or more clay than the original $\mathrm{C}$ horizon parent material is presumed to have contained. 


\section{SOIL PROFILE EX04-P01}

Location: $\quad$ Excavation at ground level, approximately 4 miles $(6.4 \mathrm{~km})$ northeast of NTS Area 3 RWMS; Nevada State Plane coordinates 842723 feet north and 697640 feet east; 4250 feet (1295 meters) elevation.

Described by: R. D. Van Remortel and K. E. Snyder

Date described: 6 May 1996

Geomorphic surface: S5a

Taxonomic classification of uppermost deposit: Haplocambid (in Unit*)

Taxonomic classification of pedon: Sandy-skeletal, mixed, thermic Typic Haplocambi

Remarks: Matrix colors are for crushed and smoothed hand samples, while colors of surface features and concentrations are for undisturbed samples. All colors are for dry conditions unless noted otherwise. The textures given are field-determined.

\section{DESCRIPTION}

$\mathbf{A}$

0 to 5.9 in. ( 0 to $15 \mathrm{~cm})$. Pale brown $(10 \mathrm{YR} 6 / 3)$ very gravelly sandy loam, dark yellowish- brown (10YR4/4) moist; weak fine granular structure; soft, very friable, nonsticky and slightly plastic; few fine roots; few medium interstitial pores; few thin paleocarbonate coatings on sides of rock fragments; 2 percent cobbles and 50 percent pebbles from mixed pyroclastic and calcareous sedimentary rocks; clear wavy boundary. (Unit * and no sample collected)

Bqk 5.9 to 12.6 in. (15 to $32 \mathrm{~cm})$. Pink (7.5YR7/3) very gravelly loamy sand, dark brown (7.5YR4/4) moist; weak medium subangular blocky structure; soft, very friable, nonsticky and nonplastic; common fine and medium roots; few medium interstitial pores; common thin silica coatings on undersides of rock fragments; Stage I- carbonate development; few thin carbonate coatings on undersides of rock fragments; common thin paleocarbonate coatings on sides of rock fragments; 55 percent pebbles from mixed pyroclastic and calcareous sedimentary rocks; clear wavy boundary. (Unit * and no sample collected) 
Bck $\quad 12.6$ to 24.0 in. (32 to $61 \mathrm{~cm}$ ). Very pale brown (10YR7/3) extremely gravelly sand, yellowish- brown (10YR5/4) moist; weak medium subangular blocky structure with areas of very faint relict bedding; soft, very friable, nonsticky and nonplastic; few fine and medium roots; Stage I- carbonate development; few thin carbonate coatings on undersides of rock fragments; common thin paleocarbonate coatings on sides of rock fragments; 60 percent pebbles from mixed pyroclastic and calcareous sedimentary rocks; clear wavy boundary. (Unit* and no sample collected)

C 24.0 to $30.7 \mathrm{in}$. (61 to $78 \mathrm{~cm}$ ). Very pale brown (10YR7/3) very gravelly sand, yellowish-brown (10YR5/4) moist; single grain with faint relict bedding; soft, very friable, nonsticky and nonplastic; few very fine roots; few thin paleocarbonate coatings on sides of rock fragments; 55 percent pebbles from mixed pyroclastic and calcareous sedimentary rocks; abrupt wavy boundary. (Unit* and no sample collected)

2Bkb 30.7 to39.4 in. (78 to $100 \mathrm{~cm}$ ). Pinkish-gray $(7.5 \mathrm{YR} 6 / 2)$ very gravelly sand, brown (7.5YR5/4) moist; weak medium subangular blocky structure; soft, very friable, nonsticky and nonplastic; few fine roots; Stage I- carbonate development; few thin carbonate coatings on undersides of rock fragments; few thin paleocarbonate coatings on sides of rock fragments; 2 percent cobbles and 45 percent pebbles from mixed pyroclastic and calcareous sedimentary rocks. (Unit* and no sample collected)

NOTES: Location was determined from a 1:48,000 base map and is accurate to within $50 \mathrm{ft}$ $(15 \mathrm{~m})$. Elevation was determined from a 1:48,000 base map and is accurate to within $5 \mathrm{ft}$ $(1.5 \mathrm{~m})$. Diagnostic features include an ochric epipedon 0 to $5.9 \mathrm{in} .(0$ to $15 \mathrm{~cm})$ and cambic horizon 5.9 to 12.6 in. (15 to $32 \mathrm{~cm}$ ). 


\section{SOIL PROFILE EX05-P01}

Location: Excavation at ground level, approximately 4 miles $(6.4 \mathrm{~km})$ northeast of NTS Area 3 RWMS; Nevada State Plane coordinates 842796 feet north and 697574 feet east; 4250 feet (1295 meters) elevation.

Described by: R. D. Van Remortel and K. E. Snyder

Sampled by: R. D. Van Remortel

Date described / sampled: 6 May 1996/21 May 1996

Geomorphic surface: $\quad$ S7

Taxonomic classification of uppermost deposit: Riverwash over Haplocambid (in Unit *)

Taxonomic classification of pedon: Sandy-skeletal, mixed, thermic Typic Haplocambids

Remarks: Matrix colors are for crushed and smoothed hand samples, while colors of surface features and concentrations are for undisturbed samples. All colors are for dry conditions unless noted otherwise. The textures given are field-determined.

\section{DESCRIPTION}

C1 0 to 4.3 in. ( 0 to $11 \mathrm{~cm})$. Pale brown $(10 \mathrm{YR} 6 / 3)$ very gravelly sand, yellowishbrown (10YR5/4) moist; single grain with faint recent bedding; loose, nonsticky and nonplastic; few very fine roots; common thin paleocarbonate coatings on sides of rock fragments; 40 percent pebbles from mixed pyroclastic and calcareous sedimentary rocks; clear wavy boundary. (Unit * and sample a01a)

C2 4.3 to 9.4 in. (11 to $24 \mathrm{~cm}$ ). Pale brown (10YR6/3) very gravelly sand, yellowishbrown (10YR5/4) moist; single grain with distinct relict bedding; soft, very friable, nonsticky and nonplastic; few very fine roots; very few thin silica coatings on undersides of rock fragments; few thin paleocarbonate coatings on sides of rock fragments; 45 percent pebbles from mixed pyroclastic and calcareous sedimentary rocks; abrupt wavy boundary. (Unit * and sample a01b) 
2BCqkb 9.4 to 21.6 in. (24 to $55 \mathrm{~cm}$ ). Pink (7.5YR7/3) extremely gravelly sand, brown (7.5YR5/4) moist; weak fine subangular blocky structure with faint relict bedding in lower part; slightly hard, friable, nonsticky and nonplastic; few very fine roots; common thin silica coatings on undersides of rock fragments; Stage I+ carbonate development; few thin carbonate coatings and few pendants on undersides of rock fragments; few thin paleocarbonate coatings on sides of rock fragments; 1 percent cobbles and 60 percent pebbles from mixed pyroclastic and calcareous sedimentary rocks. (Unit * and sample a02)

NOTES: Location was determined from a 1:48,000 base map and is accurate to within $50 \mathrm{ft}$ $(15 \mathrm{~m})$. Elevation was determined from a 1:48,000 base map and is accurate to within $5 \mathrm{ft}$ $(1.5 \mathrm{~m})$. Diagnostic features include riverwash 0 to $9.4 \mathrm{in}$. (0 to $24 \mathrm{~cm})$. 


\section{SOIL PROFILE EX06-P01}

Location: Excavation at ground level approximately 4 miles $(6.4 \mathrm{~km})$ northeast of NTS Area 3 RWMS; Nevada State Plane coordinates 842884 feet north and 697496 feet east; 4250 feet ( 1295 meters) elevation.

Described by: R. D. Van Remortel and K. E. Snyder

Sampled by: R. D. Van Remortel

Date described / sampled: 6 May 1996/21 May 1996

Geomorphic surface: S6

Taxonomic classification of uppermost deposit: Haplocambid (in Unit *)

Taxonomic classification of pedon: Sandy-skeletal, mixed, thermic Typic Haplocambids

Remarks: Matrix colors are for crushed and smoothed hand samples, while colors of surface features and concentrations are for undisturbed samples. All colors are for dry conditions unless noted otherwise. The textures given are field-determined.

\section{DESCRIPTION}

AC 0 to $2.8 \mathrm{in}$. (0 to $7 \mathrm{~cm})$. Pale brown $(10 \mathrm{YR} 6 / 3)$ very gravelly sand, yellowishbrown (10YR5/4) moist; weak fine granular structure; soft, very friable, nonsticky and nonplastic; few very fine roots; common thin paleocarbonate coatings on sides of rock fragments; 1 percent stones, 2 percent cobbles, and 50 percent pebbles from mixed pyroclastic and calcareous sedimentary rocks; clear wavy boundary. (Unit * and sample a01)

Bw 2.8 to 6.3 in. (7 to $16 \mathrm{~cm})$. Very pale brown $(10 \mathrm{YR} 7 / 3)$ very gravelly sand, dark yellowish- brown (10YR4/4) moist; weak coarse subangular blocky structure; soft, very friable, nonsticky and nonplastic; few fine roots; few thin paleocarbonate coatings on sides of rock fragments; 2 percent cobbles and 45 percent pebbles from mixed pyroclastic and calcareous sedimentary rocks; clear wavy boundary. (Unit * and sample a02) 
BCk $\quad 6.3$ to 15.7 in. (16 to $40 \mathrm{~cm})$. Very pale brown $(10 \mathrm{YR} 7 / 3)$ very gravelly sand, yellowish-brown (10YR5/4) moist; single grain with pockets of faint relict bedding; soft, very friable, nonsticky and nonplastic; few fine roots; very few thin silica coatings on undersides of rock fragments; few thin carbonate coatings on undersides of rock fragments; few thin paleocarbonate coatings on sides of rock fragments; 2 percent cobbles and 50 percent pebbles from mixed pyroclastic and calcareous sedimentary rocks; clear wavy boundary. (Unit* and sample a03)

NOTES: Location was determined from a 1:48,000 base map and is accurate to within $50 \mathrm{ft}$ $(15 \mathrm{~m})$. Elevation was determined from a 1:48,000 base map and is accurate to within $5 \mathrm{ft}$ $(1.5 \mathrm{~m})$. Diagnostic features include an ochric epipedon 0 to $2.7 \mathrm{in}$. (0 to $7 \mathrm{~cm})$ and cambic horizon 2.7 to $6.3 \mathrm{in.} \mathrm{(7} \mathrm{to} 16 \mathrm{~cm}$ ). 


\section{SOIL PROFILE EX07-P01}

Location: $\quad$ Excavation at ground level, approximately 4 miles $(6.4 \mathrm{~km})$ northeast of NTS Area 3 RWMS; Nevada State Plane coordinates 842944 feet north and 697443 feet east; 4250 feet ( 1295 meters) elevation.

Described by: R. D. Van Remortel and K. E. Snyder

Sampled by: R. D. Van Remortel

Date described / sampled: 6 May 1996/21 May 1996

Geomorphic surface: S5b

Taxonomic classification of uppermost deposit: Haplocambid (in Unit *)

Taxonomic classification of pedon: Sandy-skeletal, mixed, thermic Typic Haplocambids

Remarks: Matrix colors are for crushed and smoothed hand samples, while colors of surface features and concentrations are for undisturbed samples. All colors are for dry conditions unless noted otherwise. The textures given are field-determined.

\section{DESCRIPTION}

A

0 to 3.5 in. (0 to $9 \mathrm{~cm})$. Pale brown (10YR6/3) very gravelly loamy sand, dark yellowish- brown (10YR4/4) moist; weak fine granular structure; soft, very friable, nonsticky and nonplastic; few fine roots; common thin paleocarbonate coatings on sides of rock fragments; 5 percent stones, 5 percent cobbles, and 40 percent pebbles from mixed pyroclastic and calcareous sedimentary rocks; clear wavy boundary. (Unit * and sample a01)

Bw $\quad 3.5$ to 14.6 in. (9 to $37 \mathrm{~cm}$ ). Pink (7.5YR7/3) extremely gravelly loamy sand, light brown (7.5YR6/4) moist; weak medium subangular blocky structure; slightly hard, friable, nonsticky and nonplastic; common fine and medium roots; very few thin silica coatings on undersides of rock fragments; very few thin carbonate coatings on undersides of rock fragments; few thin paleocarbonate coatings on sides of rock fragments; 15 percent stones, 10 percent cobbles, and 40 percent pebbles from mixed pyroclastic and calcareous sedimentary rocks; clear wavy boundary. (Unit * and sample a02) 
Bk1 14.6 to 24.8 in. ( 37 to $63 \mathrm{~cm}$ ). Pink (7.5YR7/3) very gravelly loamy sand, light brown (7.5YR6/4) moist; weak medium subangular blocky structure; soft, very friable, nonsticky and nonplastic; common very fine and fine roots; Stage I carbonate development; common thin carbonate coatings on undersides of rock fragments; few thin paleocarbonate coatings on sides of rock fragments; 5 percent stones, 5 percent cobbles, and 40 percent pebbles from mixed pyroclastic and calcareous sedimentary rocks; gradual wavy boundary. (Unit* and sample a03)

Bk2 24.8 to 33.8 in. (63 to $86 \mathrm{~cm}$ ). Pinkish-gray (7.5YR7/2) very gravelly sand, light brown (7.5YR6/3) moist; weak medium subangular blocky structure; soft, very friable, nonsticky and nonplastic; few fine roots; Stage I carbonate development; common thin carbonate coatings on undersides of rock fragments; common thin paleocarbonate coatings on sides of rock fragments; 10 percent cobbles and 40 percent pebbles from mixed pyroclastic and calcareous sedimentary rocks; clear wavy boundary. (Unit * and sample a04)

BCk $\quad 33.8$ to 39.4 in. ( 86 to $100 \mathrm{~cm}$ ). Very pale brown $(10 \mathrm{YR} 7 / 3)$ extremely gravelly sand, brown (10YR4/3) moist; single grain with very faint relict bedding; loose, nonsticky and nonplastic; few very fine roots; Stage I+ carbonate development; common carbonate pendants on undersides of rock fragments; common thin paleocarbonate coatings on sides of rock fragments; 5 percent cobbles and 60 percent pebbles from mixed pyroclastic and calcareous sedimentary rocks; (Unit * and sample a05)

NOTES: Location was determined from a 1:48,000 base map and is accurate to within $50 \mathrm{ft}$ $(15 \mathrm{~m})$. Elevation was determined from a 1:48,000 base map and is accurate to within $5 \mathrm{ft}$ $(1.5 \mathrm{~m})$. Diagnostic features include an ochric epipedon 0 to $3.5 \mathrm{in}$. $(0$ to $9 \mathrm{~cm})$ and cambic horizon 3.5 to 33.8 in. (9 to $86 \mathrm{~cm}$ ). 


\section{SOIL PROFILE EX08-P01}

Location: Excavation at ground level, approximately 1.2 mile $(1.9 \mathrm{~km})$ northeast of NTS Area 3 RWMS; Nevada State Plane coordinates 839515 feet north and 693632 feet east; 4125 feet ( 1257 meters) elevation.

Described by: R. D. Van Remortel

Sampled by: R. D. Van Remortel

Date described / sampled: 30 May 1996 / 6 Jun 1996

Geomorphic surface: S5a

Taxonomic classification of uppermost deposit: Haplocambid (in Unit *)

Taxonomic classification of pedon: Sandy-skeletal, mixed, thermic Typic Haplocambids

Remarks: Matrix colors are for crushed and smoothed hand samples, while colors of surface features and concentrations are for undisturbed samples. All colors are for dry conditions unless noted otherwise. The textures given are field-determined.

\section{DESCRIPTION}

A

0 to 3.1 in. ( 0 to $8 \mathrm{~cm})$. Brown (10YR5/3) very gravelly loamy sand, dark yellowish-brown (10YR3/4) moist; weak coarse subangular blocky structure parting to weak fine granular; soft, very friable, nonsticky and nonplastic; few very fine roots; few fine interstitial pores; few thin paleocarbonate coatings on sides of rock fragments; 5 percent cobbles and 40 percent pebbles from mixed pyroclastic and calcareous sedimentary rocks; abrupt wavy boundary. (Unit * and sample a01)

Bqk 3.1 to 9.8 in. (8 to $25 \mathrm{~cm}$ ). Pink (7.5YR7/3) gravelly loamy sand, dark brown (7.5YR4/4) moist; weak medium subangular blocky structure; slightly hard, friable, nonsticky and nonplastic; few fine roots; few thin silica coatings on undersides of rock fragments; Stage I- carbonate development; few thin carbonate coatings on undersides of rock fragments; few thin paleocarbonate coatings on sides of rock fragments; 30 percent pebbles from mixed pyroclastic and calcareous sedimentary rocks; clear wavy boundary. (Unit* and sample a02) 
Bk1 9.8 to 17.0 in. (25 to $43 \mathrm{~cm}$ ). Pink (7.5YR7/3) very gravelly sandy loam, dark brown (7.5YR4/4) moist; weak medium subangular blocky structure; slightly hard, friable, nonsticky and slightly plastic; few fine roots; Stage I+ carbonate development; common thin carbonate coatings on undersides of rock fragments; few thin paleocarbonate coatings on sides of rock fragments; 40 percent pebbles from mixed pyroclastic and calcareous sedimentary rocks; clear wavy boundary. (Unit * and sample a03)

Bk2 17.0 to 25.2 in. (43 to $64 \mathrm{~cm})$. Pink (7.5YR7/3) very gravelly loamy sand, strong brown (7.5YR5/6) moist; weak fine subangular blocky structure; soft, very friable, nonsticky and nonplastic; few very fine and fine roots; Stage I carbonate development; common thin carbonate coatings on undersides of rock fragments; common thin paleocarbonate coatings on sides of rock fragments; 2 percent cobbles and 40 percent pebbles from mixed pyroclastic and calcareous sedimentary rocks; gradual wavy boundary. (Unit * and sample a04)

BCqk 25.2 to 35.4 in. (64 to $90 \mathrm{~cm})$. Light gray (10YR7/2) extremely gravelly sand, yellowish-brown (10YR5/4) moist; single grain with areas of faint relict bedding; slightly hard, friable, nonsticky and nonplastic; few very fine roots; common thin silica coatings on undersides of rock fragments; Stage I- carbonate development; common thin carbonate coatings on undersides of rock fragments; few thin paleocarbonate coatings on sides of rock fragments; 10 percent cobbles and 55 percent pebbles from mixed pyroclastic and calcareous sedimentary rocks. (Unit * and sample a05)

NOTES: Location was determined from a 1:48,000 base map and is accurate to within $50 \mathrm{ft}$ $(15 \mathrm{~m})$. Elevation was determined from a 1:48,000 base map and is accurate to within $5 \mathrm{ft}$ $(1.5 \mathrm{~m})$. Diagnostic features include an ochric epipedon 0 to $3.15 \mathrm{in}$. (0 to $8 \mathrm{~cm})$ and cambic horizon 3.15 to 25.2 in. ( 8 to $64 \mathrm{~cm}$ ). 


\section{SOIL PROFILE EX09-P01}

Location: $\quad$ Excavation at ground level, approximately 0.6 mile $(1 \mathrm{~km})$ north of NTS Area 3 RWMS; Nevada State Plane coordinates and elevation were not determined.

Described by: R. D. Van Remortel

Date described: 10 September 1996

Geomorphic surface: S5a

Taxonomic classification of uppermost deposit: Haplocambid (in Unit *)

Taxonomic classification of pedon: Sandy, mixed, thermic Typic Haplocambids

Remarks: Matrix colors are for crushed and smoothed hand samples, while colors of surface features and concentrations are for undisturbed samples. All colors are for dry conditions unless noted otherwise. The textures given are field-determined.

\section{DESCRIPTION}

A

0 to 2.0 in. ( 0 to $5 \mathrm{~cm}$ ). Pale brown (10YR6/3) gravelly loamy sand, dark brown (10YR3/3) moist; weak medium granular structure; soft, very friable, nonsticky and nonplastic; common fine roots; few thin paleocarbonate coatings on sides of rock fragments; 30 percent pebbles from mixed pyroclastic and calcareous sedimentary rocks; abrupt wavy boundary. (Unit * and no sample collected)

BA 2.0 to 4.3 in. (5 to $11 \mathrm{~cm})$. Light brown (7.5YR6/4) loamy sand, dark brown (7.5YR4/4) moist; weak fine subangular blocky structure; slightly hard, friable, nonsticky and nonplastic; common fine roots; few thin paleocarbonate coatings on sides of rock fragments; 5 percent pebbles from mixed pyroclastic and calcareous sedimentary rocks; clear wavy boundary. (Unit* and no sample collected)

Bk1 4.3 to 8.3 in. (11 to $21 \mathrm{~cm})$. Light brown $(7.5 \mathrm{YR} 6 / 4)$ sandy loam, strong brown (7.5YR4/6) moist; moderate fine subangular blocky structure; hard, firm, nonsticky and nonplastic; few fine roots; Stage I carbonate development; few fine soft carbonate masses and few thin carbonate coatings on undersides of rock fragments; 5 percent pebbles from mixed pyroclastic and calcareous sedimentary rocks; clear wavy boundary. (Unit* and no sample collected) 
Bk2 8.3 to 18.0 in. (21 to $46 \mathrm{~cm})$. Light brown (7.5YR6/4) loamy sand, dark brown (7.5YR4/4) moist; weak fine subangular blocky structure; slightly hard, friable, nonsticky and nonplastic; few fine roots; Stage I carbonate development; few fine soft carbonate masses and few thin carbonate coatings on undersides of rock fragments; 5 percent pebbles from mixed pyroclastic and calcareous sedimentary rocks; gradual wavy boundary. (Unit * and no sample collected)

Bkb $\quad 18.0$ to 31.5 in. (46 to $80 \mathrm{~cm})$. Pink $(7.5 Y R 7 / 3)$ very gravelly loamy sand, brown (7.5YR5/4) moist; weak medium subangular blocky structure; soft, very friable, nonsticky and nonplastic; few fine roots; Stage I carbonate development; few fine soft carbonate masses and few thin carbonate coatings on undersides of rock fragments; 10 percent cobbles and 25 percent pebbles from mixed pyroclastic and calcareous sedimentary rocks. (Unit * and no sample collected)

NOTES: Diagnostic features include an ochric epipedon 0 to 2 in. (0 to $5 \mathrm{~cm})$ and cambic horizon 4.3 to $31.5 \mathrm{in}$. (11 to $80 \mathrm{~cm}$ ). 


\title{
SOIL TRENCH 1 - ST01-P01 THROUGH ST01-P06
}

\author{
SOIL PROFILE ST01-P01
}

Location: $\quad$ Soil Trench 1, Profile 1, located on the east side of Yucca Flat approximately 2.5 miles $(4.0 \mathrm{~km})$ northeast of Soil Trench 3 in the Area 3 RWMS; Nevada State Plane coordinates 843990 feet north and 697815 feet east; 4287 feet (1307 meters) elevation.

Described by: R. D. Van Remortel and K. E. Snyder

Date described: 15 October 1996

Geomorphic surface: S3

Taxonomic classification of uppermost deposit: Petrocalcid (in Unit *)

Taxonomic classification of pedon: Sandy-skeletal, mixed, thermic Argic Petrocalcids

Remarks: Matrix colors are for crushed and smoothed hand samples, while colors of surface features and concentrations are for undisturbed samples. All colors are for dry conditions unless noted otherwise. The textures given are field-determined.

\section{DESCRIPTION}

A1 0 to 0.8 in. (0 to $2 \mathrm{~cm})$. Very pale brown (10YR7/3) extremely gravelly fine sandy loam, brown (10YR5/3) moist; strong coarse prismatic structure parting to moderate medium platy; slightly hard, friable, slightly sticky and slightly plastic; few fine roots; many fine vesicular pores; few thin carbonate paleocoatings on sides of rock fragments; 5 percent channer-sized pan fragments, 10 percent cobbles, and 55 percent pebbles dominantly from mixed pyroclastic and calcareous sedimentary rocks; abrupt smooth boundary. (Unit * and no sample collected)

A2 0.8 to 4.3 in. (2 to $11 \mathrm{~cm})$. Very pale brown (10YR7/3) loam, yellowish-brown (10YR5/4) moist; strong coarse prismatic structure parting to weak thick platy; slightly hard, friable, sticky and slightly plastic; few fine roots; common very fine vesicular pores; common irregular hard dark orangish-brown (7.5YR5/8) silica lamina on undersides of structural plates; few thin carbonate paleocoatings on sides of rock fragments; 2 percent pebbles dominantly from mixed pyroclastic and calcareous sedimentary rocks; abrupt wavy boundary. (Unit* and no sample collected) 
2Btk 4.3 to 7.5 in. (11 to $19 \mathrm{~cm})$. Pink (7.5YR7/4) very gravelly sandy loam, strong brown (7.5YR4/6) moist; moderate fine subangular blocky structure parting to moderate medium granular; slightly hard, friable, slightly sticky and slightly plastic; common fine and medium roots; common very fine interstitial pores; few thin argillans on contacts between peds and pebbles; very few thin silica cutans on undersides of pan fragments; highly degraded and weathered material exhibiting ancestral Stage III carbonate development; fractures 1 to $5 \mathrm{~cm}$ apart; 20 percent moderately carbonate-cemented with troweled lamina on undersides of large pan fragments; common thin carbonate coatings and few thin pendants on undersides of rock fragments; 30 percent pebble-sized pan fragments and 20 percent pebbles dominantly from mixed pyroclastic and calcareous sedimentary rocks; abrupt wavy boundary. (Unit * and no sample collected)

2Bkm1 7.5 to 15.7 in. (19 to $40 \mathrm{~cm}$ ). Pinkish-white (7.5YR8/2) very gravelly sand, light brown (7.5YR6/4) moist; moderate coarse subangular blocky structure; very hard, extremely firm, nonsticky and nonplastic; many thin light brown (7.5YR6/4, $6 / 6$ moist) silica cutans along base of horizon; weakly degraded and weathered material exhibiting ancestral Stage IV carbonate development; fractures 5 to $10 \mathrm{~cm}$ apart; light brown (7.5YR6/3, 5/4 moist) 1-mm carbonate lamina capping top of horizon; 90 percent strongly carbonate-cemented with common thin carbonate coatings and many moderately thick pendants on undersides of rock fragments; apparent paleoroot channel of 2-cm diameter and $150-\mathrm{cm}$ length along base of horizon contains light reddish-brown (5YR7/4, 4/6 moist) gravelly sand; 2 percent cobbles and 45 percent pebbles dominantly from mixed pyroclastic and calcareous sedimentary rocks; clear wavy boundary. (Unit* and no sample collected)

2Bkm2 15.7 to 26.7 in. (40 to $68 \mathrm{~cm}$ ). Pinkish-white (7.5YR8/2) extremely gravelly coarse sand, light brown (7.5YR6/4) moist; moderate medium subangular blocky structure; extremely hard, slightly rigid, nonsticky and nonplastic; very few thin silica cutans on undersides of pendants; Stage IV carbonate development; fractures 30 to $50 \mathrm{~cm}$ apart; pink ( 7.5 YR7/3, 6/3 moist) 2 -mm carbonate lamina capping top of horizon; 95 percent strongly carbonate-cemented with many thin carbonate coatings and many thick pendants on undersides of rock fragments; 10 percent cobbles and 60 percent pebbles dominantly from mixed pyroclastic and calcareous sedimentary rocks; clear wavy boundary. (Unit * and no sample collected)

2Bk 26.7 to 39.8 in. (68 to $101 \mathrm{~cm})$. Pinkish-white $(7.5 \mathrm{YR} 8 / 2)$ extremely gravelly coarse sand, light brown (7.5YR6/4) moist; moderate medium subangular blocky structure; very hard, extremely firm, nonsticky and nonplastic; very few thin silica cutans on undersides of pendants; Stage III carbonate development; fractures 10 to $20 \mathrm{~cm}$ apart; 50 percent strongly carbonate-cemented with many thin carbonate coatings and many thick pendants on undersides of rock fragments; large pockets of less-cemented sand and gravel; 10 percent cobbles and 60 percent pebbles dominantly from mixed pyroclastic and calcareous sedimentary rocks; clear wavy boundary. (Unit* and no sample collected) 
2BCk 39.8 to 52.4 in. (101 to $133 \mathrm{~cm}$ ). Pale brown (10YR6/3) extremely gravelly coarse sand, yellowish-brown (10YR5/4) moist; single grain with faint relict bedding, weak fine subangular blocky structure in some parts; hard, firm, nonsticky and nonplastic; few fine roots; very few thin silica cutans on undersides of pendants; Stage II carbonate development; 70 percent weakly cemented with common thin carbonate coatings and many moderately thick pendants on undersides of rock fragments; 10 percent cobbles and 60 percent pebbles from mixed pyroclastic and calcareous sedimentary rocks; abrupt wavy boundary. (Unit * and no sample collected)

3Bkb1 52.4 to 63.0 in. (133 to $160 \mathrm{~cm})$. Light brown $(7.5 Y R 6 / 3)$ very gravelly sand, brown (7.5YR5/4) moist; weak medium subangular blocky structure; very hard, extremely firm, nonsticky and nonplastic; Stage II+ carbonate development; discontinuous light brown (7.5YR6/4, 5/4 moist) 1-mm carbonate lamina capping top of horizon; fractures 10 to $30 \mathrm{~cm}$ apart; 65 percent moderately carbonatecemented with many thin carbonate coatings and common moderately thick pendants on undersides of rock fragments; 5 percent cobbles and 45 percent pebbles dominantly from mixed pyroclastic and calcareous sedimentary rocks; clear wavy boundary. (Unit* and no sample collected)

3Bkb2 63.0 to $70.9 \mathrm{in}$. (160 to $180 \mathrm{~cm})$. Light brown $(7.5 \mathrm{YR} 6 / 3)$ very gravelly sand, brown (7.5YR5/4) moist; weak medium subangular blocky structure; hard, firm, nonsticky and nonplastic; Stage II- carbonate development; 30 percent weakly carbonate-cemented with common thin carbonate coatings and common moderately thick pendants on undersides of rock fragments; 2 percent cobbles and 40 percent pebbles dominantly from mixed pyroclastic and calcareous sedimentary rocks. (Unit* and no sample collected)

NOTES: Location was determined by using a Global Positioning System and is accurate to within 30 feet ( 9 meters). Elevation was determined buy using a field altimeter and is accurate to within 2 feet (0.6 meters). Diagnostic features include an ochric epipedon 0 to $4.3 \mathrm{in}$. (0 to 11 $\mathrm{cm}$ ), argillic horizon 4.3 to $7.5 \mathrm{in}$. (11 to $19 \mathrm{~cm}$ ), and petrocalcic horizon 7.5 to $26.8 \mathrm{in}$. (19 to 68 $\mathrm{cm})$. The thickness of the eolian mantle in this pedon is $4.3 \mathrm{in} .(11 \mathrm{~cm})$. The argillic horizon contains 3 percent or more clay than the original $\mathrm{C}$ horizon parent material is presumed to have contained. 


\section{SOIL PROFILE ST01-P02}

Location: $\quad$ Soil Trench 1, Profile 2, located on the east side of Yucca Flat, approximately 2.5 miles $(4.0 \mathrm{~km})$ northeast of Soil Trench 3 in the Area 3 RWMS; Nevada State Plane coordinates 843980 feet north and 697820 feet east; 4287 feet (1307 meters) elevation.

Described by: R. D. Van Remortel and K. E. Snyder

Date described: 16 October 1996

Geomorphic surface: S3

Taxonomic classification of uppermost deposit: Petrocalcid (in Unit *)

Taxonomic classification of pedon: Sandy-skeletal, mixed, thermic Argic Petrocalcids

Remarks: Matrix colors are for crushed and smoothed hand samples, while colors of surface features and concentrations are for undisturbed samples. All colors are for dry conditions unless noted otherwise. The textures given are field-determined.

\section{DESCRIPTION}

A1 0 to 1.2 in. ( 0 to $3 \mathrm{~cm})$. Pale brown $(10 \mathrm{YR} 6 / 3)$ extremely gravelly fine sandy loam, yellowish- brown (10YR5/4) moist; strong coarse prismatic structure parting to moderate medium platy; slightly hard, friable, slightly sticky and slightly plastic; few fine roots; many fine vesicular pores; few thin carbonate paleocoatings on sides of rock fragments; 5 percent channer-sized pan fragments, 5 percent cobbles, and 60 percent pebbles dominantly from mixed pyroclastic and calcareous sedimentary rocks; abrupt smooth boundary. (Unit * and no sample collected)

A2 1.2 to 4.3 in. (3 to $11 \mathrm{~cm})$. Very pale brown $(10 \mathrm{YR} 7 / 3)$ loam, yellowish-brown (10YR5/4) moist; strong coarse prismatic structure parting to weak thick platy; slightly hard, friable, sticky and slightly plastic; few fine roots; common very fine vesicular pores; common irregular hard dark orangish-brown (7.5YR5/8) silica lamina on undersides of structural plates; few thin carbonate paleocoatings on sides of rock fragments; 2 percent pebbles dominantly from mixed pyroclastic and calcareous sedimentary rocks; abrupt wavy boundary. (Unit * and no sample collected) 
2Btk1 4.3 to 7.9 in. (11 to $20 \mathrm{~cm}$ ). Light brown (7.5YR6/3) very gravelly sandy loam, brown (7.5YR5/3) moist; moderate fine subangular blocky structure; hard, firm, slightly sticky and slightly plastic; common fine and medium roots; common very fine interstitial pores; few thin argillans on contacts between peds and pebbles; very few thin silica cutans on undersides of pan fragments; highly degraded and weathered material exhibiting ancestral Stage III carbonate development; fractures 1 to $5 \mathrm{~cm}$ apart; 20 percent very weakly carbonate-cemented with troweled lamina on undersides of large pan fragments; common thin carbonate coatings and few thin pendants on undersides of rock fragments; 15 percent pebble-sized pan fragments and 20 percent pebbles dominantly from mixed pyroclastic and calcareous sedimentary rocks; abrupt wavy boundary. (Unit* and no sample collected)

2Btk2 7.9 to 13.8 in. (20 to $35 \mathrm{~cm}$ ). Light brown (7.5YR6/3) very gravelly sandy loam, brown (7.5YR5/4) moist; weak fine subangular blocky structure; slightly hard, friable, slightly sticky and slightly plastic; few fine and medium roots; few very fine interstitial pores; few thin argillans on contacts between peds and pebbles; very few thin silica cutans on undersides of pan fragments; highly degraded and weathered material exhibiting ancestral Stage III carbonate development; fractures 1 to $5 \mathrm{~cm}$ apart; discontinuous $1-\mathrm{mm}$ carbonate lamina throughout 20 percent weakly carbonate-cemented with troweled lamina on undersides of large pan fragments; common thin carbonate coatings and few thin pendants on undersides of rock fragments; 30 percent pebble-sized pan fragments, 2 percent cobbles, and 20 percent pebbles dominantly from mixed pyroclastic and calcareous sedimentary rocks; abrupt wavy boundary. (Unit* and no sample collected)

2Bkm1 13.8 to 18.5 in. (35 to $47 \mathrm{~cm}$ ). Pinkish-white (7.5YR8/2) very gravelly sand, light brown (7.5YR6/3) moist; moderate coarse subangular blocky structure; very hard, extremely firm, nonsticky and nonplastic; many thin light brown (7.5YR6/4, $6 / 6$ moist) silica cutans along base of horizon; weakly degraded and weathered material exhibiting ancestral Stage IV carbonate development; fractures 5 to $10 \mathrm{~cm}$ apart; light brown (7.5YR6/3,5/4 moist) 1-mm carbonate lamina capping top of horizon; 90 percent strongly carbonate-cemented with common thin carbonate coatings and many moderately thick pendants on undersides of rock fragments; apparent paleoroot channel of 2-cm diameter and 150-cm length along base of horizon contains light reddish-brown (5YR7/4, 4/6 moist) gravelly sand; 2 percent cobbles and 45 percent pebbles dominantly from mixed pyroclastic and calcareous sedimentary rocks; clear wavy boundary. (Unit* and no sample collected) 
2Bkm2 18.5 to 33.1 in. ( 47 to $84 \mathrm{~cm}$ ). Pinkish-white (7.5YR8/2) extremely gravelly coarse sand, light brown (7.5YR6/4) moist; moderate medium subangular blocky structure; extremely hard, slightly rigid, nonsticky and nonplastic; very few thin silica cutans on undersides of pendants; Stage III carbonate development; fractures 30 to $50 \mathrm{~cm}$ apart; pink ( 7.5 YR7/3, 6/3 moist) 2-mm carbonate lamina capping top of horizon; 95 percent strongly carbonate-cemented with many thin carbonate coatings and many thick pendants on undersides of rock fragments; 10 percent cobbles and 60 percent pebbles dominantly from mixed pyroclastic and calcareous sedimentary rocks; clear wavy boundary. (Unit * and no sample collected)

2BCk $\quad 33.1$ to 47.6 in. ( 84 to $121 \mathrm{~cm}$ ). Light brown (7.5YR6/3) extremely gravelly coarse sand, brown (7.5YR5/4) moist; single grain with faint relict bedding, weak medium subangular blocky structure in some parts; hard, firm, nonsticky and nonplastic; few fine roots; very few thin silica cutans on undersides of pendants; Stage II carbonate development with occasional discontinuous carbonate lenses; 70 percent weakly cemented with common thin carbonate coatings and many moderately thick pendants on undersides of rock fragments; 10 percent cobbles and 60 percent pebbles from mixed pyroclastic and calcareous sedimentary rocks; gradual wavy boundary. (Unit* and no sample collected)

2Ck 47.6 to $63.0 \mathrm{in.}$ (121 to $160 \mathrm{~cm})$. Light brownish-gray (10YR6/2) extremely gravelly coarse sand, dark yellowish-brown (10YR4/4) moist; single grain with distinct relict bedding; slightly hard, friable, nonsticky and nonplastic; few fine roots; very few thin silica cutans on undersides of pendants; Stage I+ carbonate development with few thin discontinuous moderately carbonate-cemented lenses; common thin carbonate coatings and few thin pendants on undersides of rock fragments; 10 percent cobbles and 60 percent pebbles from mixed pyroclastic and calcareous sedimentary rocks. (Unit* and no sample collected)

NOTES: Location was determined by using a Global Positioning System and is accurate to within 30 feet ( 9 meters). Elevation was determined buy using a field altimeter and is accurate to within 2 feet (0.6 meters). Diagnostic features include an ochric epipedon 0 to 4.3 in. ( 0 to $11 \mathrm{~cm}$ ), argillic horizon 4.3 to $13.8 \mathrm{in}$. (11 to $35 \mathrm{~cm}$ ), and petrocalcic horizon 13.8 to $33.1 \mathrm{in}$. ( 35 to $84 \mathrm{~cm}$ ). The thickness of the eolian mantle in this pedon is $4.3 \mathrm{in} .(11 \mathrm{~cm})$. The argillic horizon contains 3 percent or more clay than the original $\mathrm{C}$ horizon parent material is presumed to have contained. This pedon is influenced by a degraded area, presumably a reworked root zone of a large shrub to a depth of 19.7 in. $(50 \mathrm{~cm})$, located 15.75 in. $(40 \mathrm{~cm})$ to the north-northwest. 


\section{SOIL PROFILE ST01-P03}

Location: $\quad$ Soil Trench 1, Profile 3, located on the east side of Yucca Flat approximately 2.5 miles $(4.0 \mathrm{~km})$ northeast of Soil Trench 3 in the Area 3 RWMS; Nevada State Plane coordinates 8439967 feet north and 697827 feet east; 4287 feet ( 1307 meters) elevation.

Described by: R. D. Van Remortel and K. E. Snyder

Date described: 17 October 1996

Geomorphic surface: S3

Taxonomic classification of uppermost deposit: Petrocalcid (in Unit *)

Taxonomic classification of pedon: Sandy-skeletal, mixed, thermic Argic Petrocalcids

Remarks: Matrix colors are for crushed and smoothed hand samples, while colors of surface features and concentrations are for undisturbed samples. All colors are for dry conditions unless noted otherwise. The textures given are field-determined.

\section{DESCRIPTION}

A1 0 to 0.8 in. (0 to $2 \mathrm{~cm})$. Pale brown $(10 \mathrm{YR} 6 / 3)$ extremely gravelly fine sandy loam, yellowish- brown (10YR5/4) moist; strong coarse prismatic structure parting to moderate medium platy; slightly hard, friable, slightly sticky and slightly plastic; few fine roots; few very fine vesicular pores; few thin carbonate paleocoatings on sides of rock fragments; 5 percent channer-sized pan fragments, 5 percent cobbles, and 60 percent pebbles dominantly from mixed pyroclastic and calcareous sedimentary rocks; abrupt smooth boundary. (Unit * and no sample collected)

A2

0.8 to $4.3 \mathrm{in}$. (2 to $11 \mathrm{~cm}$ ). Very pale brown (10YR7/3) loam, yellowish-brown (10YR5/4) moist; strong coarse prismatic structure parting to weak thick platy; slightly hard, friable, sticky and slightly plastic; few fine roots; common very fine vesicular pores; common irregular hard dark orangish-brown (7.5YR5/8) silica lamina on undersides of structural plates; few thin carbonate paleocoatings on sides of rock fragments; 2 percent pebbles dominantly from mixed pyroclastic and calcareous sedimentary rocks; abrupt wavy boundary. (Unit * and no sample collected) 
2Btk 4.3 to $7.5 \mathrm{in}$. (11 to $19 \mathrm{~cm})$. Light brown $(7.5 \mathrm{YR} 6 / 3)$ very gravelly sandy loam, brown (7.5YR5/3) moist; moderate fine subangular blocky structure; hard, firm, slightly sticky and slightly plastic; common fine and medium roots; common very fine interstitial pores; few thin argillans on contacts between peds and pebbles; very few thin silica cutans on undersides of pan fragments; highly degraded and weathered material exhibiting ancestral Stage III carbonate development; fractures 1 to $5 \mathrm{~cm}$ apart; 20 percent moderately carbonate-cemented with troweled lamina on undersides of large pan fragments; common thin carbonate coatings and few thin pendants on undersides of rock fragments; 30 percent pebble-sized pan fragments and 20 percent pebbles dominantly from mixed pyroclastic and calcareous sedimentary rocks; abrupt wavy boundary. (Unit* and no sample collected)

2Bkm1 7.5 to 14.1 in. (19 to $36 \mathrm{~cm})$. Pinkish-white (7.5YR8/2) very gravelly sand, light brown (7.5YR6/3) moist; moderate coarse subangular blocky structure; very hard, extremely firm, nonsticky and nonplastic; many thin light brown (7.5YR6/4, $6 / 6$ moist) silica cutans along base of horizon; weakly degraded and weathered material exhibiting ancestral Stage IV carbonate development; fractures 5 to $10 \mathrm{~cm}$ apart; light brown (7.5YR6/3, 5/4 moist) 1-mm carbonate lamina capping top of horizon; 90 percent strongly carbonate-cemented with common thin carbonate coatings and many moderately thick pendants on undersides of rock fragments; apparent paleoroot channel of $2-\mathrm{cm}$ diameter and $150-\mathrm{cm}$ length along base of horizon contains light reddish-brown (5YR7/4, 4/6 moist) gravelly sand; 2 percent cobbles and 45 percent pebbles dominantly from mixed pyroclastic and calcareous sedimentary rocks; clear wavy boundary. (Unit * and no sample collected)

2Bkm2 14.1 to 27.6 in. (36 to $70 \mathrm{~cm}$ ). Pinkish-white (7.5YR8/2) extremely gravelly coarse sand, light brown (7.5YR6/4) moist; moderate medium subangular blocky structure; extremely hard, slightly rigid, nonsticky and nonplastic; very few thin silica cutans on undersides of pendants; Stage III carbonate development; fractures 30 to $50 \mathrm{~cm}$ apart; pink ( 7.5 YR7/3, 6/3 moist) $2-\mathrm{mm}$ carbonate lamina capping top of horizon; 95 percent strongly carbonate-cemented with many thin carbonate coatings and many thick pendants on undersides of rock fragments; 10 percent cobbles and 60 percent pebbles dominantly from mixed pyroclastic and calcareous sedimentary rocks; clear wavy boundary. (Unit * and no sample collected) 
2BCk 27.6 to 45.7 in. (70 to $116 \mathrm{~cm}$ ). Light brown (7.5YR6/3) extremely gravelly coarse sand, brown (7.5YR5/4) moist; single grain with distinct relict bedding, weak medium subangular blocky structure in some parts; hard, firm, nonsticky and nonplastic; trace of fine roots; very few thin silica cutans on undersides of pendants; Stage II carbonate development with occasional discontinuous moderately carbonate-cemented lenses; 70 percent weakly cemented with common thin carbonate coatings and many moderately thick pendants on undersides of rock fragments; 10 percent cobbles and 60 percent pebbles from mixed pyroclastic and calcareous sedimentary rocks; gradual wavy boundary. (Unit* and no sample collected)

2Ck 45.7 to $63.0 \mathrm{in}$. (116 to $160 \mathrm{~cm})$. Light brownish gray (10YR6/2) extremely gravelly coarse sand, dark yellowish-brown (10YR4/4) moist; single grain with prominent relict bedding; slightly hard, friable, nonsticky and nonplastic; few fine roots; very few thin silica cutans on undersides of pendants; Stage I carbonate development with few thin discontinuous moderately carbonate-cemented lenses; common thin carbonate coatings and very few thin pendants on undersides of rock fragments; 10 percent cobbles and 60 percent pebbles from mixed pyroclastic and calcareous sedimentary rocks. (Unit * and no sample collected)

NOTES: Location was determined by using a Global Positioning System and is accurate to within 30 feet ( 9 meters). Elevation was determined buy using a field altimeter and is accurate to within 2 feet (0.6 meters). Diagnostic features include an ochric epipedon 0 to $4.3 \mathrm{in}$. (0 to $11 \mathrm{~cm}$ ), argillic horizon 4.3 to $7.5 \mathrm{in}$. (11 to $19 \mathrm{~cm}$ ), and petrocalcic horizon 7.5 to $27.6 \mathrm{in}$. (19 to $70 \mathrm{~cm}$ ). The thickness of the eolian mantle in this pedon is $7.5 \mathrm{in}$. $(11 \mathrm{~cm})$. The argillic horizon contains 3 percent or more clay than the original $\mathrm{C}$ horizon parent material is presumed to have contained. 


\section{SOIL PROFILE ST01-P04}

Location: $\quad$ Soil Trench 1, Profile 4, located on the east side of Yucca Flat, approximately 2.5 miles $(4.0 \mathrm{~km})$ northeast of Soil Trench 3 in the Area 3 RWMS; Nevada State Plane coordinates 843958 feet north and 697832 feet east; 4287 feet (1307 meters) elevation.

Described by: $\quad$ R. D. Van Remortel and K. E. Snyder

Date described: 17 October 1996

Geomorphic surface: S3

Taxonomic classification of uppermost deposit: Petrocalcid (in Unit *)

Taxonomic classification of pedon: Sandy-skeletal, mixed, thermic Argic Petrocalcids

Remarks: Matrix colors are for crushed and smoothed hand samples, while colors of surface features and concentrations are for undisturbed samples. All colors are for dry conditions unless noted otherwise. The textures given are field-determined.

\section{DESCRIPTION}

A1 0 to 1.2 in. (0 to $3 \mathrm{~cm})$. Pale brown (10YR6/3) extremely gravelly fine sandy loam, yellowish- brown (10YR5/4) moist; strong coarse prismatic structure parting to moderate medium platy; slightly hard, friable, slightly sticky and slightly plastic; few fine roots; many fine vesicular pores; few thin carbonate paleocoatings on sides of rock fragments; 5 percent channer-sized pan fragments, 5 percent cobbles, and 60 percent pebbles dominantly from mixed pyroclastic and calcareous sedimentary rocks; abrupt smooth boundary. (Unit * and no sample collected)

A2

1.2 to 4.3 in. ( 3 to $11 \mathrm{~cm}$ ). Very pale brown (10YR7/3) loam, yellowish-brown (10YR5/4) moist; strong coarse prismatic structure parting to weak thick platy; slightly hard, friable, sticky and slightly plastic; few fine roots; common very fine vesicular pores; common irregular hard dark orangish-brown (7.5YR5/8) silica lamina on undersides of structural plates; few thin carbonate paleocoatings on sides of rock fragments; 2 percent pebbles dominantly from mixed pyroclastic and calcareous sedimentary rocks; abrupt wavy boundary. (Unit * and no sample collected) 
2Btk1 4.3 to 8.3 in. (11 to $21 \mathrm{~cm}$ ). Pink ( 7.5 YR7/4) very gravelly sandy loam, strong brown (7.5YR4/6) moist; moderate fine subangular blocky structure; hard, firm, slightly sticky and slightly plastic; common fine and medium roots; common very fine interstitial pores; few thin argillans on contacts between peds and pebbles; very few thin silica cutans on undersides of pan fragments; highly degraded and weathered material exhibiting ancestral Stage III carbonate development; fractures 1 to $5 \mathrm{~cm}$ apart; 20 percent moderately carbonate-cemented with troweled lamina on undersides of large pan fragments; common thin carbonate coatings and few thin pendants on undersides of rock fragments; 20 percent pebble-sized pan fragments and 20 percent pebbles dominantly from mixed pyroclastic and calcareous sedimentary rocks; abrupt wavy boundary. (Unit * and no sample collected)

2Btk2 8.3 to 11.4 in. (21 to $29 \mathrm{~cm}$ ). Light brown (7.5YR6/3) very gravelly sandy loam, brown (7.5YR5/4) moist; weak fine subangular blocky structure; slightly hard, friable, slightly sticky and slightly plastic; few fine and medium roots; few very fine interstitial pores; few thin argillans on contacts between peds and pebbles; very few thin silica cutans on undersides of pan fragments; moderately degraded and weathered material exhibiting ancestral Stage III- carbonate development; fractures 1 to $5 \mathrm{~cm}$ apart; few discontinuous $1-\mathrm{mm}$ carbonate lamina throughout; 60 percent weakly to moderately carbonate-cemented with troweled lamina on undersides of large pan fragments; common thin carbonate coatings and few thin pendants on undersides of rock fragments; 30 percent pebble-sized pan fragments, 2 percent cobbles, and 20 percent pebbles dominantly from mixed pyroclastic and calcareous sedimentary rocks; abrupt wavy boundary. (Unit* and no sample collected)

2Bkm1 11.4 to 17.0 in. (29 to $43 \mathrm{~cm})$. Pinkish-white (7.5YR8/2) very gravelly sand, light brown (7.5YR6/3) moist; moderate coarse subangular blocky structure; very hard, extremely firm, nonsticky and nonplastic; many thin light brown (7.5YR6/4, $6 / 6$ moist) silica cutans along base of horizon; weakly degraded and weathered material exhibiting ancestral Stage IV carbonate development; fractures 5 to $10 \mathrm{~cm}$ apart; light brown (7.5YR6/3,5/4 moist) 1-mm carbonate lamina capping top of horizon; 90 percent strongly carbonate-cemented with common thin carbonate coatings and many moderately thick pendants on undersides of rock fragments; apparent paleoroot channel of $2-\mathrm{cm}$ diameter and $150-\mathrm{cm}$ length along base of horizon contains light reddish-brown (5YR7/4, 4/6 moist) gravelly sand; 2 percent cobbles and 45 percent pebbles dominantly from mixed pyroclastic and calcareous sedimentary rocks; clear wavy boundary. (Unit * and no sample collected) 
2Bkm2 17.0 to 27.2 in. (43 to $69 \mathrm{~cm}$ ). Pinkish-white (7.5YR8/2) extremely gravelly coarse sand, light brown (7.5YR6/4) moist; moderate medium subangular blocky structure; extremely hard, slightly rigid, nonsticky and nonplastic; very few thin silica cutans on undersides of pendants; Stage III+ carbonate development; fractures 30 to $50 \mathrm{~cm}$ apart; pink ( 7.5 YR7/3, 6/3 moist) 2-mm carbonate lamina capping top of horizon; 95 percent strongly carbonate-cemented with many thin carbonate coatings and many thick pendants on undersides of rock fragments; 10 percent cobbles and 60 percent pebbles dominantly from mixed pyroclastic and calcareous sedimentary rocks; clear wavy boundary. (Unit * and no sample collected)

2Bk 27.2 to 36.6 in. (69 to $93 \mathrm{~cm}$ ). Pinkish-white (7.5YR8/2) extremely gravelly coarse sand, light brown (7.5YR6/4) moist; weak medium subangular blocky structure; very hard, very firm, nonsticky and nonplastic; very few thin silica cutans on undersides of pendants; Stage III- carbonate development; fractures 30 to $50 \mathrm{~cm}$ apart; 75 percent moderately to strongly carbonate-cemented with many thin carbonate coatings and many moderately thick pendants on undersides of rock fragments; 10 percent cobbles and 60 percent pebbles dominantly from mixed pyroclastic and calcareous sedimentary rocks; clear wavy boundary. (Unit * and no sample collected)

2BCk 36.6 to 46.4 in. (93 to $118 \mathrm{~cm}$ ). Pinkish-white (7.5YR8/2) extremely gravelly coarse sand, light brown (7.5YR6/4) moist; single grain within faint relict bedding, weak medium subangular blocky structure in parts; very hard, extremely firm, nonsticky and nonplastic; trace of fine roots; very few thin silica cutans on undersides of pendants; Stage III- carbonate development; fractures 10 to $20 \mathrm{~cm}$ apart; 50 percent strongly carbonate-cemented with many thin carbonate coatings and many thick pendants on undersides of rock fragments; large pockets of lesscemented sand and gravel; 10 percent cobbles and 60 percent pebbles dominantly from mixed pyroclastic and calcareous sedimentary rocks; clear wavy boundary. (Unit * and no sample collected)

2Ck 46.4 to 63.0 in. (118 to $160 \mathrm{~cm})$. Brown (10YR5/3) extremely gravelly coarse sand, dark yellowish- brown (10YR4/4) moist; single grain with distinct relict bedding, weak medium subangular blocky structure in some parts; hard, firm, nonsticky and nonplastic; few fine roots; very few thin silica cutans on undersides of pendants; Stage II carbonate development with few discontinuous moderately carbonatecemented lenses and paleoroot channels; 70 percent very weakly carbonatecemented with common thin carbonate coatings and many moderately thick pendants on undersides of rock fragments; 10 percent cobbles and 60 percent pebbles from mixed pyroclastic and calcareous sedimentary rocks. (Unit* and no sample collected) 
NOTES: Location was determined by using a Global Positioning System and is accurate to within 30 feet ( 9 meters). Elevation was determined buy using a field altimeter and is accurate to within 2 feet ( 0.6 meters). Diagnostic features include an ochric epipedon 0 to 4.3 in. ( 0 to $11 \mathrm{~cm}$ ), argillic horizon 4.3 to $11.4 \mathrm{in}$. (11 to $29 \mathrm{~cm}$ ), and petrocalcic horizon 11.4 to $36.6 \mathrm{in}$. (29 to $93 \mathrm{~cm}$ ). The thickness of the eolian mantle in this pedon is $11 \mathrm{~cm}$. The argillic horizon contains 3 percent or more clay than the original $\mathrm{C}$ horizon parent material is presumed to have contained. Surface disturbance by excavation necessitated the interpolation of Al horizon properties from adjacent undisturbed areas. 


\section{SOIL PROFILE ST01-P05}

Location: $\quad$ Soil Trench 1, Profile 5, located on the east side of Yucca Flat, approximately 2.5 miles $(4.0 \mathrm{~km})$ northeast of Soil Trench 3 in the Area 3 RWMS; Nevada State Plane coordinates 843941 feet north and 697842 feet east; 4287 feet (1307 meters) elevation.

Described by: $\quad$ R. D. Van Remortel and K. E. Snyder

Date described: 16 October 1996

Geomorphic surface: S3

Taxonomic classification of uppermost deposit: Petrocalcid (in Unit *)

Taxonomic classification of pedon: Sandy-skeletal, mixed, thermic Argic Petrocalcids

Remarks: Matrix colors are for crushed and smoothed hand samples, while colors of surface features and concentrations are for undisturbed samples. All colors are for dry conditions unless noted otherwise. The textures given are field-determined.

\section{DESCRIPTION}

A1 0 to 1.2 in. (0 to $3 \mathrm{~cm})$. Pale brown $(10 \mathrm{YR} 6 / 3)$ extremely gravelly fine sandy loam, yellowish- brown (10YR5/4) moist; moderate medium prismatic structure parting to moderate medium platy; slightly hard, friable, slightly sticky and slightly plastic; trace of fine roots; many fine vesicular pores; few thin carbonate paleocoatings on sides of rock fragments; 10 percent channer-sized pan fragments, 10 percent cobbles, and 50 percent pebbles dominantly from mixed pyroclastic and calcareous sedimentary rocks; abrupt smooth boundary. (Unit * and no sample collected)

A2 1.2 to 3.9 in. (3 to $10 \mathrm{~cm})$. Very pale brown $(10 \mathrm{YR} 7 / 3)$ very fine sandy loam, brown (10YR5/3) moist; moderate coarse prismatic structure parting to weak thick platy; slightly hard, friable, sticky and plastic; trace of fine roots; many very fine vesicular pores; very few irregular hard dark orangish-brown (7.5YR4/8) silica lamina on undersides of structural plates; few thin carbonate paleocoatings on sides of rock fragments; 2 percent pebbles dominantly from mixed pyroclastic and calcareous sedimentary rocks; abrupt wavy boundary. (Unit * and no sample collected) 
2Btk 3.9 to 8.3 in. (10 to $21 \mathrm{~cm})$. Light brown $(7.5 \mathrm{YR} 6 / 4)$ very gravelly sandy loam, strong brown (7.5YR4/6) moist; moderate fine and medium subangular blocky structure; slightly hard, friable, slightly sticky and slightly plastic; many fine and few medium and coarse roots; common very fine interstitial pores; few thin argillans on contacts between peds and pebbles; very few thin silica cutans on undersides of pan fragments; highly degraded and weathered material exhibiting ancestral Stage III carbonate development; fractures 1 to $5 \mathrm{~cm}$ apart; 15 percent moderately carbonate-cemented with troweled lamina on undersides of large pan fragments; common thin carbonate coatings and few thin pendants on undersides of rock fragments; 25 percent pebble-sized pan fragments and 20 percent pebbles dominantly from mixed pyroclastic and calcareous sedimentary rocks; clear wavy boundary. (Unit * and no sample collected)

2Bkm 8.3 to 15.0 in. (21 to $38 \mathrm{~cm}$ ). Pinkish-gray $(7.5 Y R 7 / 2)$ very gravelly coarse sand, light brown (7.5YR6/4) moist; moderate fine subangular blocky structure; extremely hard, slightly rigid, nonsticky and nonplastic; few thin light brown (7.5YR6/4, 6/6 moist) silica cutans along base of horizon; weakly degraded and weathered material exhibiting ancestral Stage IV carbonate development; fractures 5 to $10 \mathrm{~cm}$ apart; light brown (7.5YR6/4, 5/6 moist) 1-mm carbonate lamina capping top of horizon and in center of horizon; 90 percent strongly carbonate-cemented with common thin carbonate coatings and many thick pendants on undersides of rock fragments; 5 percent cobbles and 50 percent pebbles dominantly from mixed pyroclastic and calcareous sedimentary rocks; abrupt wavy boundary. (Unit* and no sample collected)

2Bk 15.0 to 20.9 in. (38 to $53 \mathrm{~cm}$ ). Pinkish-white $(7.5 \mathrm{YR} 8 / 2$ ) extremely gravelly coarse sand, light brown (7.5YR6/4) moist; moderate medium subangular blocky structure; very hard, extremely firm, nonsticky and nonplastic; very few thin silica cutans on undersides of pendants; Stage II+ carbonate development; fractures 5 to $20 \mathrm{~cm}$ apart; 60 percent moderately to strongly carbonate-cemented with many thin carbonate coatings and many thick pendants on undersides of rock fragments; large pockets of less-cemented sand and gravel; 2 percent cobbles and 65 percent pebbles dominantly from mixed pyroclastic and calcareous sedimentary rocks; clear irregular boundary. (Unit * and no sample collected)

2BCk 20.9 to 36.6 in. (53 to $93 \mathrm{~cm}$ ). Pink (7.5YR7/3) extremely gravelly coarse sand, strong brown (7.5YR5/6) moist; single grain with faint relict bedding, weak medium subangular blocky structure in parts; hard, firm, nonsticky and nonplastic; very few thin silica cutans on undersides of pendants; Stage II+ carbonate development; fractures 10 to $20 \mathrm{~cm}$ apart; 70 percent weakly cemented with common thin carbonate coatings and many moderately thick pendants on undersides of rock fragments; 2 percent cobbles and 70 percent pebbles from mixed pyroclastic and calcareous sedimentary rocks; abrupt wavy boundary. (Unit * and no sample collected) 
2Ck 36.6 to 58.3 in. (93 to $148 \mathrm{~cm}$ ). Very pale brown (10YR7/3) extremely gravelly coarse sand, yellowish-brown (10YR5/6) moist; single grain with prominent relict bedding; slightly hard, friable, nonsticky and nonplastic; few fine roots; very few thin silica cutans on undersides of pendants; Stage I carbonate development with few thin discontinuous moderately carbonate-cemented lenses; common thin carbonate coatings and very few thin pendants on undersides of rock fragments; 2 percent cobbles and 60 percent pebbles from mixed pyroclastic and calcareous sedimentary rocks; abrupt wavy boundary. (Unit * and no sample collected)

3Bkb $\quad 58.3$ to $66.9 \mathrm{in}$. (148 to $170 \mathrm{~cm})$. Pink $(7.5$ YR7/3) very gravelly coarse sand, dark brown (7.5YR4/4) moist; moderate medium subangular blocky structure; hard, firm, nonsticky and nonplastic; Stage II carbonate development; fractures 10 to $20 \mathrm{~cm}$ apart; 80 percent weakly carbonate-cemented with many thin carbonate coatings and common moderately thick pendants on undersides of rock fragments; 5 percent cobbles and 35 percent pebbles dominantly from mixed pyroclastic and calcareous sedimentary rocks. (Unit* and no sample collected)

NOTES: Location was determined by using a Global Positioning System and is accurate to within 30 feet ( 9 meters). Elevation was determined buy using a field altimeter and is accurate to within 2 feet ( 0.6 meters). Diagnostic features include an ochric epipedon 0 to 3.93 in. (0 to $10 \mathrm{~cm}$ ), argillic horizon 3.9 to 8.27 in. ( 10 to $21 \mathrm{~cm}$ ), and petrocalcic horizon 8.27 to $14.96 \mathrm{in}$. $(21$ to $38 \mathrm{~cm})$. The thickness of the eolian mantle in this pedon is $3.9 \mathrm{in} .(10 \mathrm{~cm})$. The argillic horizon contains 3 percent or more clay than the original $\mathrm{C}$ horizon parent material is presumed to have contained. Almost identical to Profile 1 except that this profile has no 2BCk horizon because depth to the paleosol is shallower on this southeast end of the trench. Surface disturbance by excavation necessitated the interpolation of AI horizon properties from adjacent undisturbed areas. 


\section{SOIL PROFILE ST01-P06}

Location: $\quad$ Soil Trench 1, Profile 6, located on the east side of Yucca Flat, approximately 2.5 miles $(4.0 \mathrm{~km})$ northeast of Soil Trench 3 in the Area 3 RWMS; Nevada State Plane coordinates 843928 feet north and 697849 feet east; 4287 feet (1307 meters) elevation.

Described by: $\quad$ R. D. Van Remortel and K. E. Snyder

Date described: 15 October 1996

Geomorphic surface: S3

Taxonomic classification of uppermost deposit: Petrocalcid (in Unit *)

Taxonomic classification of pedon: Sandy-skeletal, mixed, thermic Argic Petrocalcids

Remarks: Matrix colors are for crushed and smoothed hand samples, while colors of surface features and concentrations are for undisturbed samples. All colors are for dry conditions unless noted otherwise. The textures given are field-determined.

\section{DESCRIPTION}

A1 0 to $0.8 \mathrm{in.} \mathrm{(0} \mathrm{to} 2 \mathrm{~cm})$. Pale brown (10YR6/3) extremely gravelly sandy loam, dark yellowish- brown (10YR4/4) moist; moderate coarse prismatic structure parting to moderate medium platy; slightly hard, friable, slightly sticky and slightly plastic; few fine roots; many fine vesicular pores; few thin carbonate paleocoatings on sides of rock fragments; 10 percent channer-sized pan fragments, 10 percent cobbles, and 50 percent pebbles dominantly from mixed pyroclastic and calcareous sedimentary rocks; abrupt wavy boundary. (Unit * and no sample collected)

A2 0.8 to 5.5 in. (2 to $14 \mathrm{~cm}$ ). Very pale brown $(10 \mathrm{YR} 7 / 3)$ very fine sandy loam, yellowish-brown (10YR5/4) moist; moderate coarse prismatic structure parting to weak thick platy; slightly hard, friable, sticky and plastic; few fine roots; many very fine vesicular pores; few irregular hard dark orangish-brown (7.5YR4/8) silica lamina on undersides of structural plates; few thin carbonate paleocoatings on sides of rock fragments; 2 percent pebbles dominantly from mixed pyroclastic and calcareous sedimentary rocks; clear wavy boundary. (Unit * and no sample collected) 
2Btk $\quad 5.5$ to 9.4 in. (14 to $24 \mathrm{~cm}$ ). Pink ( 7.5 YR7/4) very gravelly sandy loam, strong brown (7.5YR5/6) moist; moderate fine subangular blocky structure parting to moderate medium granular; slightly hard, friable, slightly sticky and slightly plastic; many fine and few medium and coarse roots; common very fine interstitial pores; few thin argillans on contacts between peds and pebbles; very few thin silica cutans on undersides of pan fragments; highly degraded and weathered material exhibiting ancestral Stage III carbonate development; fractures 0.5 to $5 \mathrm{~cm}$ apart; 15 percent moderately carbonate-cemented with troweled lamina on undersides of large pan fragments; common thin carbonate coatings and few thin pendants on undersides of rock fragments; 25 percent pebble-sized pan fragments and 20 percent pebbles dominantly from mixed pyroclastic and calcareous sedimentary rocks; clear wavy boundary. (Unit * and no sample collected)

2Bkm1 9.4 to 14.6 in. (24 to $37 \mathrm{~cm}$ ). Pinkish-gray (7.5YR7/2) very gravelly coarse sand, light brown (7.5YR6/4) moist; moderate fine subangular blocky structure; extremely hard, slightly rigid, nonsticky and nonplastic; few thin light brown (7.5YR6/4, 6/6 moist) silica cutans along base of horizon; weakly degraded and weathered material exhibiting ancestral Stage IV carbonate development; fractures 5 to $10 \mathrm{~cm}$ apart; light brown $(7.5 \mathrm{YR} 6 / 4,5 / 6$ moist $) 1-\mathrm{mm}$ carbonate lamina capping top of horizon and in center of horizon; 90 percent strongly carbonate-cemented with common thin carbonate coatings and many thick pendants on undersides of rock fragments; 5 percent cobbles and 50 percent pebbles dominantly from mixed pyroclastic and calcareous sedimentary rocks; abrupt wavy boundary. (Unit * and no sample collected)

2Bkm2 14.6 to 18.1 in. (37 to $46 \mathrm{~cm}$ ). Pinkish-white (7.5YR8/2) extremely gravelly sand, pink (7.5YR7/4) moist; moderate fine subangular blocky structure; extremely hard, slightly rigid, nonsticky and nonplastic; trace of very fine roots; very few thin silica cutans on undersides of pendants; Stage IV carbonate development; fractures 30 to $60 \mathrm{~cm}$ apart; pink ( 7.5 YR7/4, $6 / 4$ moist) 2-mm carbonate lamina capping top of horizon; 95 percent strongly carbonate-cemented with many thin carbonate coatings and many thick pendants on undersides of rock fragments; 2 percent cobbles and 65 percent pebbles dominantly from mixed pyroclastic and calcareous sedimentary rocks; gradual wavy boundary. (Unit* and no sample collected)

2Bk $\quad 18.1$ to 25.2 in. (46 to $64 \mathrm{~cm}$ ). Pinkish-white (7.5YR8/2) extremely gravelly coarse sand, light brown (7.5YR6/4) moist; moderate medium subangular blocky structure; very hard, extremely firm, nonsticky and nonplastic; very few thin silica cutans on undersides of pendants; Stage III carbonate development; fractures 5 to $20 \mathrm{~cm}$ apart; 60 percent moderately to strongly carbonate-cemented with many thin carbonate coatings and many thick pendants on undersides of rock fragments; large pockets of less-cemented sand and gravel; 2 percent cobbles and 65 percent pebbles dominantly from mixed pyroclastic and calcareous sedimentary rocks; clear wavy boundary. (Unit* and no sample collected) 
2BCk 25.2 to $39.8 \mathrm{in}$. (64 to $101 \mathrm{~cm})$. Pink (7.5YR7/3) extremely gravelly coarse sand, strong brown (7.5YR5/6) moist; single grain with faint relict bedding, weak medium subangular blocky structure in parts; hard, firm, nonsticky and nonplastic; very few thin silica cutans on undersides of pendants; Stage II+ carbonate development; fractures 10 to $20 \mathrm{~cm}$ apart; 70 percent weakly cemented with common thin carbonate coatings and many moderately thick pendants on undersides of rock fragments; 2 percent cobbles and 70 percent pebbles from mixed pyroclastic and calcareous sedimentary rocks; abrupt wavy boundary. (Unit * and no sample collected)

3Bkb1 39.8 to 48.0 in. (101 to $122 \mathrm{~cm}$ ). Pink (7.5YR7/4) very gravelly coarse sand, reddish-yellow (7.5YR6/6) moist; moderate medium subangular blocky structure; hard, firm, nonsticky and nonplastic; Stage II carbonate development; fractures 10 to $20 \mathrm{~cm}$ apart; 80 percent weakly carbonate-cemented with many thin carbonate coatings and common moderately thick pendants on undersides of rock fragments; 5 percent cobbles and 35 percent pebbles dominantly from mixed pyroclastic and calcareous sedimentary rocks; clear wavy boundary. (Unit * and no sample collected)

3Bkb2 48.0 to 63.0 in. (122 to $160 \mathrm{~cm}$ ). Pink (7.5YR7/3) very gravelly sand, brown (7.5YR5/4) moist; weak medium subangular blocky structure; slightly hard, friable, nonsticky and nonplastic; Stage I+ carbonate development; common thin carbonate coatings and common thin pendants on undersides of rock fragments; 5 percent cobbles and 45 percent pebbles dominantly from mixed pyroclastic and calcareous sedimentary rocks. (Unit * and no sample collected)

NOTES: Location was determined by using a Global Positioning System and is accurate to within 30 feet ( 9 meters). Elevation was determined buy using a field altimeter and is accurate to within 2 feet ( 0.6 meters). Diagnostic features include an ochric epipedon 0 to $5.5 \mathrm{in}$. ( 0 to $14 \mathrm{~cm}$ ), argillic horizon 5.5 to $9.45 \mathrm{in}$. (14 to $24 \mathrm{~cm}$ ), and petrocalcic horizon 9.45 to $25.2 \mathrm{in}$. $(24$ to $64 \mathrm{~cm})$. The thickness of the eolian mantle in this pedon is $5.5 \mathrm{in}$. $(14 \mathrm{~cm})$. The argillic horizon contains 3 percent or more clay than the original $\mathrm{C}$ horizon parent material is presumed to have contained. Almost identical to Profile 1 except that this profile has no 2BCk horizon because depth to the paleosol is shallower on this southeast end of the trench. Surface disturbance by excavation necessitated the interpolation of A I horizon properties from adjacent undisturbed areas. 


\title{
SOIL TRENCH 2 - ST02-P01 THROUGH ST02-P07
}

\author{
SOIL PROFILE ST02-P01
}

Location: $\quad$ Soil Trench 2, Profile 1, located 6.2 feet (1.9 meters) from northwest stake along trench wall of fan piedmont on east side of Yucca Flat upslope from NTS Area 3 RWMS; Nevada State Plane coordinates 843103.5 feet north and 691438.1 feet east; 4124.5 feet (1257.1 meters) elevation.

Described by: R. D. Van Remortel

Sampled by: R. D. Van Remortel

Date described / sampled: 22 October 1996 / 3 February 1997

Geomorphic surface: S5b*

Taxonomic classification of uppermost deposit: Haplocambid (in Unit *)

Taxonomic classification of pedon: Sandy-skeletal, mixed, thermic Argic Petrocalcids

Remarks: Matrix colors are for crushed and smoothed hand samples, while colors of surface features and concentrations are for undisturbed samples. All colors are for dry conditions unless noted otherwise. The textures given are field-determined.

\section{DESCRIPTION}

A

0 to 2.4 in. (0 to $6 \mathrm{~cm})$. Pale brown (10YR6/3) gravelly loamy sand, dark yellowish-brown (10YR3/4) moist; weak coarse prismatic structure parting to moderate thin platy; soft, very friable, nonsticky and nonplastic; few fine roots; common very fine vesicular pores; few thin paleocarbonate coatings on sides of rock fragments; 25 percent pebbles from mixed pyroclastic and calcareous sedimentary rocks; abrupt wavy boundary. (Unit Z and sample $01 \mathrm{a}^{*}$ )

AB 2.4 to 5.5 in. (6 to $14 \mathrm{~cm})$. Light yellowish-brown (10YR6/4) loamy sand, dark yellowish-brown (10YR4/4) moist; weak coarse prismatic structure parting to weak medium subangular blocky; soft, very friable, nonsticky and nonplastic; common very fine roots; few fine interstitial pores; few thin paleocarbonate coatings on sides of rock fragments; 5 percent pebbles from mixed pyroclastic and calcareous sedimentary rocks; clear wavy boundary. (Unit Z and sample $01 \mathrm{~b} *$ ) 
Bkb1 5.5 to 15.0 in. (14 to $38 \mathrm{~cm}$ ). Pink (7.5YR7/3) gravelly sandy loam, strong brown (7.5YR4/6) moist; weak fine subangular blocky structure; slightly hard, friable, slightly sticky and slightly plastic; few very fine roots; Stage I- carbonate development; few thin carbonate coatings on undersides of rock fragments; few thin paleocarbonate coatings on sides of rock fragments; 1 percent cobbles and 20 percent pebbles from mixed pyroclastic and calcareous sedimentary rocks; gradual wavy boundary. (Unit Y and sample 02*)

Bkb2 15.0 to 22.0 in. (38 to $56 \mathrm{~cm}$ ). Pink ( 7.5 YR7/3) very gravelly sandy loam, strong brown (7.5YR5/6) moist; weak fine subangular blocky structure; soft, very friable, nonsticky and slightly plastic; common fine and medium roots; very few thin silica cutans on undersides of rock fragments; Stage I- carbonate development; common thin carbonate coatings on undersides of rock fragments; 2 percent cobbles and 40 percent pebbles from mixed pyroclastic and calcareous sedimentary rocks; abrupt wavy boundary. (Unit $\mathrm{Y}$ and sample $03^{*}$ )

BCkb $\quad 22.0$ to $28.0 \mathrm{in}$. (56 to $71 \mathrm{~cm}$ ). Light brown (7.5YR6/4) very gravelly loamy sand, brown (7.5YR5/4) moist; single grain with areas of very faint relict bedding; loose, nonsticky and nonplastic; few fine and medium roots; very few thin silica coatings on undersides of rock fragments; Stage I- carbonate development; common thin carbonate coatings on undersides of rock fragments; few thin paleocarbonate coatings on sides of rock fragments; 2 percent cobbles and 45 percent pebbles from mixed pyroclastic and calcareous sedimentary rocks; abrupt wavy boundary. (Unit $\mathrm{Y}$ and sample $04 *$ )

2Btkb $\quad 28.0$ to $35.0 \mathrm{in}$. (71 to $89 \mathrm{~cm}$ ). Pink ( 7.5 YR $8 / 3$ ) very gravelly loamy sand, strong brown (7.5YR5/6) moist; strong fine subangular blocky structure; very hard, extremely firm, nonsticky and nonplastic; trace of fine and medium roots; few thin argillans on contacts between peds and pebbles; very few thin silica cutans on undersides of rock fragments; weakly degraded and weathered material exhibiting ancestral Stage III carbonate development; 85 percent moderately to strongly carbonate-cemented with common moderately thick pendants on undersides of rock fragments; 2 percent cobbles and 40 percent pebbles dominantly from mixed pyroclastic and calcareous sedimentary rocks; clear wavy boundary. (Unit X2 and sample $05^{*}$ )

2Bkmb $\quad 35.0$ to $47.2 \mathrm{in}$. ( 89 to $120 \mathrm{~cm}$ ). Pinkish-white $(7.5 \mathrm{YR} 8 / 2)$ very gravelly loamy sand, light brown (7.5YR6/4) moist; strong medium platy structure parting to moderate medium subangular blocky; extremely hard, slightly rigid, nonsticky and nonplastic; Stage III+ carbonate development; pink (7.5YR7/4, 6/4 moist) 2-mm carbonate lamina capping horizon and $1-\mathrm{mm}$ lamina recurring along major lateral fractures throughout; 95 percent strongly carbonate-cemented with many thin carbonate coatings and many moderately thick pendants on undersides of rock fragments; I percent cobbles and 35 percent pebbles dominantly from mixed pyroclastic and calcareous sedimentary rocks; clear wavy boundary. (Unit X2 and sample $06^{*}$ ) 
2Bkb1 47.2 to $57.1 \mathrm{in}$. (120 to $145 \mathrm{~cm})$. Pink (7.5YR7/3) very gravelly loamy sand, strong brown (7.5YR5/6) moist; weak medium subangular blocky structure; hard, firm, nonsticky and nonplastic; few fine roots; Stage I+ carbonate development; 20 percent weakly carbonate-cemented with many thin pendants on undersides of rock fragments; 2 percent cobbles and 40 percent pebbles dominantly from mixed pyroclastic and calcareous sedimentary rocks; gradual wavy boundary. (Unit X2 and sample $07^{*}$ )

2Bkb2 57.1 to 62.6 in. (145 to $159 \mathrm{~cm})$. Pinkish-white $(7.5 \mathrm{YR} 8 / 2)$ very gravelly sand, light brown (7.5YR6/4) moist; weak coarse subangular blocky structure; slightly hard, friable, nonsticky and nonplastic; few very fine roots; Stage II- carbonate development; 20 percent weakly carbonate-cemented with common thin carbonate coatings and pendants on undersides of rock fragments; 2 percent cobbles and 35 percent pebbles dominantly from mixed pyroclastic and calcareous sedimentary rocks; gradual wavy boundary. (Unit X2 and sample $\left.08 \mathrm{a}^{*}\right)$

2Bkb3 62.6 to 69.3 in. (159 to $176 \mathrm{~cm}$ ). Pink (7.5YR7/3) very gravelly loamy sand, brown (7.5YR5/4) moist; weak medium subangular blocky structure; soft, very friable, nonsticky and nonplastic; few very fine roots; Stage I carbonate development; few thin carbonate coatings and pendants on undersides of rock fragments; 2 percent cobbles and 35 percent pebbles dominantly from mixed pyroclastic and calcareous sedimentary rocks; clear wavy boundary. (Unit X2 and sample $08 b^{*}$ )

2BCkb $\quad 69.3$ to $75.6 \mathrm{in}$. (176 to $192 \mathrm{~cm}$ ). Pink (7.5YR7/3) very gravelly sand, strong brown (7.5YR5/6) moist; single grain with faint relict bedding, weak medium subangular blocky structure in parts; hard, firm, nonsticky and nonplastic; very few thin argillans on contacts between peds and pebbles; very few thin silica cutans on undersides of rock fragments; Stage I+ carbonate development; numerous discontinuous thin moderately carbonate-cemented lenses with 1-mm lamina throughout and few thin pendants on undersides of rock fragments; common thin paleocarbonate coatings on sides of rock fragments; 5 percent cobbles and 45 percent pebbles dominantly from mixed pyroclastic and calcareous sedimentary rocks; abrupt wavy boundary. (Unit X2 and sample 09*)

2B'tkb $\quad 75.6$ to 82.3 in. (192 to $209 \mathrm{~cm})$. Pink (7.5YR7/4) gravelly loamy sand, strong brown (7.5YR5/6) moist; strong fine and medium angular blocky structure; very hard, very firm, nonsticky and nonplastic; few thin argillans on faces of peds; Stage II+ carbonate development; pink (7.5YR7/4, 6/4 moist) discontinuous 1-mm carbonate lamina capping horizon; 40 percent moderately carbonate-cemented with common thin carbonate coatings and few thin pendants on undersides of rock fragments; 2 percent cobbles and 25 percent pebbles dominantly from mixed pyroclastic and calcareous sedimentary rocks; abrupt wavy boundary. (Unit X2 and sample $10^{*}$ ) 
3Btkmb $\quad 82.3$ to $94.5 \mathrm{in}$. (209 to $240 \mathrm{~cm}$ ). Pink (7.5YR7/3) very gravelly loamy sand, brown (7.5YR5/4) moist; moderate fine and medium subangular blocky structure; extremely hard, slightly rigid, nonsticky and nonplastic; common thin argillans on faces of peds; Stage III carbonate development; discontinuous 1-mm carbonate lamina at top of horizon; 90 percent strongly carbonate-cemented with many thin carbonate coatings and few thin pendants on undersides of peds and rock fragments; 5 percent cobbles and 45 percent pebbles dominantly from mixed pyroclastic and calcareous sedimentary rocks; clear wavy boundary. (Unit W2 and sample $11^{*}$ )

3Bkb1 94.5 to 102.8 in. (240 to $261 \mathrm{~cm})$. Pink (7.5YR8/3) very gravelly loamy sand, light brown (7.5YR6/4) moist; moderate thin platy structure parting to moderate fine subangular blocky; hard, firm, nonsticky and nonplastic; Stage II carbonate development; 80 percent moderately carbonate-cemented with several discontinuous 1-mm carbonate lamina throughout and common thin pendants on undersides of rock fragments; 2 percent cobbles and 55 percent pebbles dominantly from mixed pyroclastic and calcareous sedimentary rocks; gradual irregular boundary. (Unit W2 and sample 12)

3Bkb2 102.8 to 108.3 in. (261 to $275 \mathrm{~cm})$. Pink (7.5YR7/3) very gravelly loamy sand, brown (7.5YR5/4) moist; weak coarse subangular blocky structure; slightly hard, friable, nonsticky and nonplastic; Stage I+ carbonate development; discontinuous 1-mm carbonate lamina at top of horizon; common moderately thick pendants on undersides of rock fragments; 2 percent cobbles and 45 percent pebbles dominantly from mixed pyroclastic and calcareous sedimentary rocks; abrupt wavy boundary. (Unit W1 and sample 13)

3B'kmb $\quad 108.3$ to 114.2 in. (275 to $290 \mathrm{~cm}$ ). Pinkish-gray (7.5YR7/2) gravelly sand, light brown (7.5YR6/3) moist; strong thin platy structure parting to moderate fine subangular blocky; rigid, nonsticky and nonplastic; Stage IV carbonate development; pink (7.5YR7/4, 6/4 moist) 2-mm carbonate lamina capping horizon; 95 percent very strongly carbonate-cemented with many thin carbonate coatings and many moderately thick pendants on undersides of rock fragments; 25 percent pebbles dominantly from mixed pyroclastic and calcareous sedimentary rocks. (Unit W1 and no sample collected*)

NOTES: Bench break at 59 in. $(150 \mathrm{~cm})$. Location was determined by triangulation using surveyed reference stakes and is accurate to within 0.25 feet $(0.08$ meters). Elevation was determined from surveyed reference elevations and is accurate to within 0.1 feet $(0.03$ meters). Diagnostic features include an ochric epipedon 0 to $5.5 \mathrm{in}$. (0 to $14 \mathrm{~cm})$, argillic horizon 28 to 35 in. (71 to $89 \mathrm{~cm}$ ), petrocalcic horizon 35 to 47.25 in. ( 89 to $120 \mathrm{~cm}$ ), and calcic horizon 47.25 to $57.1 \mathrm{in}$. (120 to $145 \mathrm{~cm})$. Located within apparent turbation zone. 


\section{SOIL PROFILE ST02-P02}

Location: $\quad$ Soil Trench 2, Profile 2, located 47.6 feet (14.5 meters) from northwest stake along trench wall of fan piedmont on east side of Yucca Flat upslope from NTS Area 3 RWMS; Nevada State Plane coordinates 843083.9 feet north and 691474.5 feet east; 4124.1 feet (1257.0 meters) elevation.

Described by: R. D. Van Remortel

Sampled by: not sampled

Date described / sampled: 24 October 1996 / not sampled

Geomorphic surface: S7*

Taxonomic classification of uppermost deposit: Torriorthent (in Unit *)

Taxonomic classification of pedon: Sandy-skeletal, mixed, thermic Argic Petrocalcids

Remarks: Matrix colors are for crushed and smoothed hand samples, while colors of surface features and concentrations are for undisturbed samples. All colors are for dry conditions unless noted otherwise. The textures given are field-determined.

\section{DESCRIPTION}

AC 0 to 3.1 in. (0 to $8 \mathrm{~cm})$. Pale brown (10YR6/3) very gravelly sand, dark yellowish-brown (10YR4/4) moist; weak fine granular structure; soft, very friable, nonsticky and nonplastic; few fine roots; few thin paleocarbonate coatings on sides of rock fragments; 3 percent cobbles and 35 percent pebbles from mixed pyroclastic and calcareous sedimentary rocks; abrupt wavy boundary. (Unit Z)

C $\quad 3.1$ to $5.1 \mathrm{in}$. (8 to $13 \mathrm{~cm})$. Light gray $(10 \mathrm{YR} 7 / 2)$ very gravelly coarse sand, pale brown (10YR6/3) moist; single grain with faint relict bedding, weak thin platy structure in parts; soft, very friable, nonsticky and nonplastic; common fine roots; few thin paleocarbonate coatings on sides of rock fragments; 2 percent cobbles and 40 percent pebbles from mixed pyroclastic and calcareous sedimentary rocks; abrupt wavy boundary. (Unit Z) 
Bkb1 5.1 to 10.6 in. (13 to $27 \mathrm{~cm})$. Pale brown (10YR6/3) gravelly loamy sand, yellowish-brown (10YR5/4) moist; weak medium platy structure parting to weak medium subangular blocky; slightly hard, friable, nonsticky and nonplastic; common fine and medium roots; few fine interstitial pores; Stage I carbonate development; common very fine soft carbonate masses and common thin carbonate coatings on undersides of rock fragments; few thin paleocarbonate coatings on sides of rock fragments; 15 percent pebbles from mixed pyroclastic and calcareous sedimentary rocks; abrupt wavy boundary. (Unit Y)

Bkb2 10.6 to 17.7 in. (27 to $45 \mathrm{~cm}$ ). Pink ( $7.5 Y R 7 / 3$ ) gravelly loamy sand, strong brown (7.5YR5/6) moist; weak coarse subangular blocky structure; soft, very friable, nonsticky and nonplastic; common fine roots; Stage I carbonate development; common thin carbonate coatings on undersides of rock fragments; 30 percent pebbles from mixed pyroclastic and calcareous sedimentary rocks; clear wavy boundary. (Unit Y)

2Btkb $\quad 17.7$ to 26.4 in. ( 45 to $67 \mathrm{~cm}$ ). Pink ( 7.5 YR7/3) very gravelly loamy sand, strong brown (7.5YR6/6) moist; strong fine subangular blocky structure; slightly hard, friable, nonsticky and nonplastic; common very fine roots; few thin argillans on contacts between peds and pebbles; few thin silica cutans on undersides of pan fragments; highly degraded and weathered material exhibiting ancestral Stage III carbonate development; 90 percent weakly to moderately carbonate-cemented with many thin pendants on undersides of rock fragments; 25 percent pebblesized pan fragments and 30 percent pebbles dominantly from mixed pyroclastic and calcareous sedimentary rocks; abrupt wavy boundary. (Unit X2)

2Bkmb 26.4 to 37.4 in. (67 to $95 \mathrm{~cm}$ ). Pinkish-white (7.5YR8/2) very gravelly loamy sand, light brown (7.5YR6/4) moist; strong medium platy structure parting to moderate medium subangular blocky; extremely hard, slightly rigid, nonsticky and nonplastic; trace of fine roots; very few thin silica cutans on undersides of rock fragments; Stage III+ carbonate development; pink (7.5YR7/4, 6/4 moist) 2-mm carbonate lamina capping horizon and 1 -mm lamina recurring along major lateral fractures throughout; 95 percent strongly carbonate-cemented with many thin carbonate coatings and many moderately thick pendants on undersides of rock fragments; 1 percent cobbles and 35 percent pebbles dominantly from mixed pyroclastic and calcareous sedimentary rocks; clear wavy boundary. (Unit X2)

2Bkb $\quad 37.4$ to 44.5 in. (95 to $113 \mathrm{~cm})$. Pinkish-white $(7.5 Y R 8 / 2)$ very gravelly loamy sand, light brown (7.5YR6/4) moist; moderate medium subangular blocky structure; hard, firm, nonsticky and nonplastic; few very fine roots; Stage II carbonate development; 50 percent weakly carbonate-cemented with common thin pendants on undersides of rock fragments; 1 percent cobbles and 35 percent pebbles dominantly from mixed pyroclastic and calcareous sedimentary rocks; clear wavy boundary. (Unit X2) 
2BCkb 44.5 to 54.3 in. (113 to $138 \mathrm{~cm}$ ). Very pale brown (10YR8/4) very gravelly coarse sand, brownish- yellow (10YR6/6) moist; single grain with very faint relict bedding, weak coarse subangular blocky structure in parts; soft, very friable, nonsticky and nonplastic; trace of fine roots; Stage I+ carbonate development; common thin carbonate coatings and pendants on undersides of rock fragments; common thin paleocarbonate coatings on sides of rock fragments; 1 percent cobbles and 45 percent pebbles dominantly from mixed pyroclastic and calcareous sedimentary rocks; gradual irregular boundary. (Unit X2)

2Ckb1 54.3 to 63.4 in. (138 to $161 \mathrm{~cm})$. Light yellowish-brown (10YR6/4) extremely gravelly coarse sand, dark yellowish-brown (10YR4/6) moist; single grain with prominent relict bedding; slightly hard, friable, nonsticky and nonplastic; Stage Icarbonate development; very weakly cemented in parts, and few thin carbonate coatings and pendants on undersides of rock fragments; common thin paleocarbonate coatings on sides of rock fragments; 2 percent cobbles and 60 percent pebbles dominantly from mixed pyroclastic and calcareous sedimentary rocks; abrupt wavy boundary. (Unit X2)

2Ckb2 63.4 to $72.0 \mathrm{in}$. (161 to $183 \mathrm{~cm})$. Light yellowish-brown (10YR6/4) extremely gravelly coarse sand, dark yellowish-brown (10YR4/6) moist; single grain with prominent relict bedding; soft, very friable, nonsticky and nonplastic; Stage Icarbonate development; very weakly cemented at base of horizon, and few thin carbonate coatings and pendants on undersides of rock fragments; common thin paleocarbonate coatings on sides of rock fragments; 2 percent cobbles and 65 percent pebbles dominantly from mixed pyroclastic and calcareous sedimentary rocks; abrupt wavy boundary. (Unit X2)

3Bkmb $\quad 72.0$ to 79.1 in. (183 to $201 \mathrm{~cm})$. Pink (7.5YR7/3) very gravelly sand, brown (7.5YR5/4) moist; moderate fine subangular blocky structure; extremely hard, slightly rigid, nonsticky and nonplastic; Stage III carbonate development; pink (7.5YR7/4, 6/4 moist) discontinuous 1-mm carbonate lamina capping horizon; 95 percent strongly carbonate-cemented with many thin carbonate coatings and many moderately thick pendants on undersides of rock fragments; 2 percent cobbles and 40 percent pebbles dominantly from mixed pyroclastic and calcareous sedimentary rocks; clear wavy boundary. (Unit W2)

3Bkb 79.1 to 87.4 in. (201 to $222 \mathrm{~cm}$ ). Pink (7.5YR7/3) very gravelly coarse sand, brown (7.5YR5/4) moist; weak medium subangular blocky structure; very hard, very firm, nonsticky and nonplastic; Stage II+ carbonate development; 80 percent weakly to moderately carbonate-cemented with many thin carbonate coatings and common thin pendants on undersides of rock fragments; 2 percent cobbles and 55 percent pebbles dominantly from mixed pyroclastic and calcareous sedimentary rocks; clear wavy boundary. (Unit W2) 
3BCkb $\quad 87.4$ to 99.2 in. (222 to $252 \mathrm{~cm}$ ). Pink (7.5YR8/3) extremely gravelly coarse sand, brown (7.5YR5/4) moist; single grain with very faint relict bedding, weak medium subangular blocky structure in parts; hard, firm, nonsticky and nonplastic; very few thin silica cutans on undersides of rock fragments; Stage IIcarbonate development; 40 percent very weakly carbonate-cemented with common thin carbonate coatings and pendants on undersides of rock fragments; few thin paleocarbonate coatings on sides of rock fragments; 2 percent cobbles and 60 percent pebbles dominantly from mixed pyroclastic and calcareous sedimentary rocks; abrupt wavy boundary. (Unit W2)

3B'kmb $\quad 99.2$ to 107.9 in. ( 252 to $274 \mathrm{~cm})$. Pink (7.5YR8/3) very gravelly loamy sand, light brown (7.5YR6/4) moist; moderate fine subangular blocky structure; rigid, nonsticky and nonplastic; Stage III carbonate development; 90 percent strongly carbonate-cemented with many thin carbonate coatings and many moderately thick pendants on undersides of rock fragments; 2 percent cobbles and 50 percent pebbles dominantly from mixed pyroclastic and calcareous sedimentary rocks; clear wavy boundary. (Unit W1)

3B'kb $\quad 107.9$ to 114.2 in. (274 to $290 \mathrm{~cm}$ ). Pink (7.5YR7/4) very gravelly loamy coarse sand, reddish-yellow (7.5YR6/6) moist; weak medium subangular blocky structure; very hard, very firm, nonsticky and nonplastic; very few thin silica cutans on undersides of rock fragments; Stage II+ carbonate development; 60 percent weakly to moderately carbonate-cemented with common thin carbonate coatings and many thin pendants on undersides of rock fragments; 2 percent cobbles and 45 percent pebbles dominantly from mixed pyroclastic and calcareous sedimentary rocks. (Unit W1)

NOTES: Bench break at 49.2 in. $(125 \mathrm{~cm})$. Location was determined by triangulation using surveyed reference stakes and is accurate to within 0.25 feet ( 0.08 meters). Elevation was determined from surveyed reference elevations and is accurate to within 0.1 feet $(0.03$ meters $)$. Diagnostic features include an ochric epipedon 0 to $3.15 \mathrm{in}$. (0 to $8 \mathrm{~cm}$ ), argillic horizon 17.7 to 26.38 in. (45 to $67 \mathrm{~cm}$ ), petrocalcic horizon 26.38 to 37.4 in. (67 to $95 \mathrm{~cm}$ ), and calcic horizon 37.4 to $44.5 \mathrm{in}$. (95 to $113 \mathrm{~cm}$ ). Soil horizons in the lower portion of the profile to the northwest of this location are very different than those in this description. Description in the upper portion of profile not made on mapped trench face due to stream erosion between the time of trench mapping and soil descriptions. 


\section{SOIL PROFILE ST02-P03}

Location: $\quad$ Soil Trench 2, Profile 3, located 68.6 feet (20.9 meters) from northwest stake along trench wall of fan piedmont on east side of Yucca Flat upslope from NTS Area 3 RWMS; Nevada State Plane coordinates 843073.9 feet north and 691492.9 feet east; 4125.6 feet (1257.5 meters) elevation.

Described by: R. D. Van Remortel

Sampled by: Not sampled

Date described / sampled: 24 October 1996 / not sampled

Geomorphic surface: S5a*

Taxonomic classification of uppermost deposit: Haplocambid (in Unit D*)

Taxonomic classification of pedon: Sandy-skeletal, mixed, thermic Argic Petrocalcids

Remarks: Matrix colors are for crushed and smoothed hand samples, while colors of surface features and concentrations are for undisturbed samples. All colors are for dry conditions unless noted otherwise. The textures given are field-determined.

\section{DESCRIPTION}

A1 0 to 1.2 in. (0 to $3 \mathrm{~cm})$. Very pale brown $(10 \mathrm{YR} 7 / 3)$ very gravelly fine sandy loam, yellowish- brown (10YR5/4) moist; moderate coarse prismatic structure parting to moderate thin platy; soft, very friable, slightly sticky and slightly plastic; few fine roots; many fine vesicular pores; few thin paleocarbonate coatings on sides of rock fragments; 2 percent cobbles and 35 percent pebbles from mixed pyroclastic and calcareous sedimentary rocks; abrupt smooth boundary. (Unit Y)

A2 1.2 to 4.3 in. (3 to $11 \mathrm{~cm})$. Light yellowish-brown $(10 \mathrm{YR} 6 / 4)$ sandy loam, yellowish-brown (10YR5/6) moist; moderate coarse prismatic structure parting to moderate thin and medium platy; slightly hard, friable, slightly sticky and slightly plastic; few fine roots; few thin paleocarbonate coatings on sides of rock fragments; 5 percent pebbles from mixed pyroclastic and calcareous sedimentary rocks; abrupt wavy boundary. (Unit Y) 
Bk1 4.3 to 10.2 in. (11 to $26 \mathrm{~cm})$. Pink $(7.5 \mathrm{YR} 7 / 3)$ sandy loam, strong brown (7.5YR5/6) moist; moderate coarse prismatic structure parting to weak medium subangular blocky; slightly hard, friable, nonsticky and slightly plastic; few fine roots; few very fine interstitial pores; Stage I carbonate development; few thin carbonate coatings on undersides of rock fragments; few thin paleocarbonate coatings on sides of rock fragments; 10 percent pebbles from mixed pyroclastic and calcareous sedimentary rocks; clear wavy boundary. (Unit Y)

Bk2 10.2 to 18.1 in. (26 to $46 \mathrm{~cm})$. Pink (7.5YR7/3) loamy sand, brown $(7.5 Y R 5 / 4)$ moist; weak coarse subangular blocky structure; soft, very friable, nonsticky and nonplastic; common fine and medium roots; Stage I carbonate development; common very fine soft masses and common thin carbonate coatings on undersides of rock fragments; 5 percent pebbles from mixed pyroclastic and calcareous sedimentary rocks; gradual wavy boundary. (Unit Y)

BCk 18.1 to 33.5 in. (46 to $85 \mathrm{~cm})$. Pink (7.5YR7/3) loamy sand, brown $(7.5 Y R 5 / 4)$ moist; single grain with faint relict bedding; soft, very friable, nonsticky and nonplastic; few fine and medium roots; Stage I- carbonate development; few thin carbonate coatings on undersides of rock fragments; 5 percent pebbles from mixed pyroclastic and calcareous sedimentary rocks; abrupt wavy boundary. (Unit Y)

2Btkb $\quad 33.5$ to 43.0 in. ( 85 to $109 \mathrm{~cm})$. Pink (7.5YR7/4) very gravelly sandy loam, strong brown (7.5YR5/6) moist; strong fine subangular blocky structure; hard, firm, slightly sticky and slightly plastic; few fine roots; few thin argillans on contacts between peds and pebbles; moderately degraded and weathered material exhibiting ancestral Stage III carbonate development; 70 percent weakly to moderately carbonate-cemented with many thin pendants on undersides of rock fragments; 30 percent pebble-sized pan fragments, 1 percent cobbles, and 30 percent pebbles dominantly from mixed pyroclastic and calcareous sedimentary rocks; clear wavy boundary. (Unit X2)

2Bkmb $\quad 43.0$ to $55.5 \mathrm{in}$. (109 to $141 \mathrm{~cm})$. Pink $(7.5 \mathrm{YR} 8 / 3)$ very gravelly loamy sand, light brown (7.5YR6/4) moist; moderate medium platy structure parting to strong medium subangular blocky; extremely hard, slightly rigid, nonsticky and nonplastic; few fine roots; very few thin silica cutans on undersides of rock fragments; Stage III+ carbonate development; pink (7.5YR7/4, 6/4 moist) 2-mm carbonate lamina capping horizon and 1-mm lamina recurring along major lateral fractures throughout; 95 percent strongly carbonate-cemented with many thin carbonate coatings and many moderately thick pendants on undersides of rock fragments; 1 percent cobbles and 45 percent pebbles dominantly from mixed pyroclastic and calcareous sedimentary rocks; clear wavy boundary. (Unit X2) 
2Bkb1 55.5 to 62.6 in. (141 to $159 \mathrm{~cm})$. Pink (5YR7/3) gravelly sandy loam, yellowishred (5YR5/6) moist; moderate medium and coarse prismatic structure parting to strong fine and medium subangular blocky; hard, firm, nonsticky and slightly plastic; few very fine roots; very few thin argillans on contacts between peds and pebbles; Stage II carbonate development; 50 percent weakly carbonate-cemented with common thin carbonate coatings and pendants on undersides of rock fragments; 2 percent cobbles and 25 percent pebbles dominantly from mixed pyroclastic and calcareous sedimentary rocks; clear wavy boundary. (Unit X2)

2Bkb2 62.6 to $68.5 \mathrm{in}$. (159 to $174 \mathrm{~cm})$. Pink (7.5YR7/3) very gravelly loamy sand, brown (7.5YR5/4) moist; moderate medium subangular blocky structure; hard, firm, nonsticky and nonplastic; few very fine roots; Stage I+ carbonate development; common thin carbonate coatings and pendants on undersides of rock fragments; 5 percent cobbles and 50 percent pebbles dominantly from mixed pyroclastic and calcareous sedimentary rocks; clear wavy boundary. (Unit X2)

2BCkb 68.5 to $72.8 \mathrm{in}$. (174 to $185 \mathrm{~cm})$. Light brown (7.5YR6/3) very gravelly coarse sand, brown (7.5YR4/4) moist; single grain with very faint relict bedding; soft, very friable, nonsticky and nonplastic; trace of fine roots; very few thin silica cutans on undersides of rock fragments; Stage I+ carbonate development; common thin carbonate coatings and pendants on undersides of rock fragments; common thin paleocarbonate coatings on sides of rock fragments; 5 percent cobbles and 50 percent pebbles dominantly from mixed pyroclastic and calcareous sedimentary rocks; gradual irregular boundary. (Unit X2)

2Ckb 72.8 to $89.0 \mathrm{in}$. (185 to $226 \mathrm{~cm}$ ). Light yellowish-brown (10YR6/4) extremely gravelly coarse sand, dark yellowish-brown (10YR4/6) moist; single grain with faint relict bedding; loose, nonsticky and nonplastic; very few thin silica cutans on undersides of rock fragments; Stage I carbonate development; common thin pendants on undersides of rock fragments; common thin paleocarbonate coatings on sides of rock fragments; 2 percent cobbles and 60 percent pebbles dominantly from mixed pyroclastic and calcareous sedimentary rocks; abrupt wavy boundary. (Unit X2)

3Bkmb $\quad 89.0$ to 100.8 in. (226 to $256 \mathrm{~cm})$. Pink (7.5YR8/3) very gravelly sand, light brown (7.5YR6/4) moist; strong medium subangular blocky structure; very hard, very firm, nonsticky and nonplastic; few thin silica cutans on undersides of rock fragments; Stage III- carbonate development; 85 percent moderately to strongly carbonate-cemented with common thin carbonate coatings and pendants on undersides of rock fragments; 2 percent cobbles and 45 percent pebbles dominantly from mixed pyroclastic and calcareous sedimentary rocks; clear wavy boundary. (Unit W2) 
3Bkb $\quad 100.8$ to 105.5 in. (256 to $268 \mathrm{~cm}$ ). Pink (7.5YR7/3) very gravelly coarse sand, brown (7.5YR5/4) moist; moderate medium subangular blocky structure; hard, firm, nonsticky and nonplastic; Stage II carbonate development; 50 percent weakly carbonate-cemented with common thin carbonate coatings and pendants on undersides of rock fragments; 5 percent cobbles and 50 percent pebbles dominantly from mixed pyroclastic and calcareous sedimentary rocks; clear wavy boundary. (Unit W2)

3BCkb $\quad 105.5$ to 114.2 in. (268 to $290 \mathrm{~cm}$ ). Pink (7.5YR7/3) very gravelly sand, brown (7.5YR5/4) moist; weak coarse subangular blocky structure, single grain with very faint relict bedding in parts; soft, very friable, nonsticky and nonplastic; very few thin silica cutans on undersides of rock fragments; Stage I+ carbonate development; common thin carbonate coatings and pendants on undersides of rock fragments; few thin paleocarbonate coatings on sides of rock fragments; 1 percent cobbles and 35 percent pebbles dominantly from mixed pyroclastic and calcareous sedimentary rocks. (Unit W2)

NOTES: Bench break at 53.15 in. $(135 \mathrm{~cm})$. Location was determined by triangulation using surveyed reference stakes and is accurate to within 0.25 feet $(0.08$ meters). Elevation was determined from surveyed reference elevations and is accurate to within 0.1 feet $(0.03$ meters). Diagnostic features include an ochric epipedon 0 to $3.15 \mathrm{in}$. (0 to $8 \mathrm{~cm}$ ), argillic horizon 17.7 to 26.38 in. (45 to $67 \mathrm{~cm}$ ), petrocalcic horizon 26.38 to $37.4 \mathrm{in}$. (67 to $95 \mathrm{~cm}$ ), and calcic horizon 37.4 to $44.5 \mathrm{in}$. (95 to $113 \mathrm{~cm}$ ). The $3 \mathrm{Bkmb}$ here is part of the 15 percent that is not well cemented. 


\section{SOIL PROFILE ST02-P04}

Location: $\quad$ Soil Trench 2, Profile 4, located 132.6 feet (40.4 meters) from northwest stake along trench wall of fan piedmont on east side of Yucca Flat upslope from NTS Area 3 RWMS; Nevada State Plane coordinates 843043.5 feet north and 691549.2 feet east; 4127.4 feet (1258.0 meters) elevation.

Described by: R. D. Van Remortel

Sampled by: R. D. Van Remortel

Date described / sampled: 24 October 1996 / 4 February 1997

Geomorphic surface: S5a

Taxonomic classification of uppermost deposit: Haplargid (in Unit E*)

Taxonomic classification of pedon: *Loamy-skeletal, mixed, thermic Typic Haplargids

Remarks: Matrix colors are for crushed and smoothed hand samples, while colors of surface features and concentrations are for undisturbed samples. All colors are for dry conditions unless noted otherwise. The textures given are field-determined.

\section{DESCRIPTION}

A1 0 to 0.4 in. (0 to $1 \mathrm{~cm})$. Pale brown $(10 \mathrm{YR} 6 / 3)$ gravelly fine sandy loam, yellowish-brown (10YR5/4) moist; strong coarse prismatic structure parting to strong thin platy; soft, very friable, slightly sticky and slightly plastic; trace of fine roots; many fine vesicular pores; few thin paleocarbonate coatings on sides of rock fragments; 30 percent pebbles from mixed pyroclastic and calcareous sedimentary rocks; abrupt smooth boundary. (Unit Y and sample 01a*)

A2 0.4 to 3.9 in. (1 to $10 \mathrm{~cm})$. Light yellowish-brown (10YR6/4) fine sandy loam, dark yellowish- brown (10YR4/6) moist; strong coarse prismatic structure parting to moderate thin platy; slightly hard, friable, slightly sticky and slightly plastic; trace of fine roots; common very fine vesicular pores; very few thin silica cutans on undersides of plates; few thin paleocarbonate coatings on sides of rock fragments; 10 percent pebbles from mixed pyroclastic and calcareous sedimentary rocks; abrupt wavy boundary. (Unit Y and sample $01 b^{*}$ ) 
2Btk $\quad 3.9$ to 8.7 in. (10 to $22 \mathrm{~cm})$. Light brown (7.5YR6/4) gravelly sandy loam, strong brown (7.5YR4/6) moist; strong coarse prismatic structure parting to moderate fine and medium subangular blocky structure; hard, firm, slightly sticky and slightly plastic; few fine roots; few very fine vesicular pores; few thin argillans on contacts between peds and pebbles; very few thin silica cutans on undersides of rock fragments; Stage I- carbonate development; few thin carbonate coatings on undersides of rock fragments; few thin paleocarbonate coatings on sides of rock fragments; 15 percent pebbles from mixed pyroclastic and calcareous sedimentary rocks; clear wavy boundary. (Unit Y and sample 02*)

2Bk 8.7 to 18.5 in. (22 to $47 \mathrm{~cm}$ ). Pink (7.5YR7/3) very gravelly loamy sand, brown (7.5YR5/4) moist; weak coarse subangular blocky structure; soft, very friable, nonsticky and nonplastic; common fine and medium roots; Stage I carbonate development; common thin carbonate coatings on undersides of rock fragments; common thin paleocarbonate coatings on sides of rock fragments; 35 percent pebbles from mixed pyroclastic and calcareous sedimentary rocks; gradual wavy boundary. (Unit Y and sample 03*)

2BCk $\quad 18.5$ to $33.5 \mathrm{in}$. (47 to $85 \mathrm{~cm}$ ). Pale brown (10YR6/3) very gravelly coarse sand, dark yellowish- brown (10YR4/6) moist; single grain with faint relict bedding; soft, very friable, nonsticky and nonplastic; common fine and medium roots; very few thin silica cutans on undersides of rock fragments; Stage I- carbonate development; few thin carbonate coatings on undersides of rock fragments; few thin paleocarbonate coatings on sides of rock fragments; 1 percent cobbles and 50 percent pebbles from mixed pyroclastic and calcareous sedimentary rocks; gradual wavy boundary. (Unit Y and sample 04*)

2Ck1 33.5 to 65.4 in. ( 85 to $166 \mathrm{~cm}$ ). Brown (10YR5/4) extremely gravelly coarse sand with several discontinuous strata of gravelly sand, dark yellowish-brown (10YR4/4) moist; single grain with prominent relict bedding; loose, nonsticky and nonplastic; few fine roots; Stage I- carbonate development; few thin carbonate coatings on undersides of rock fragments; common moderately thick paleocarbonate coatings on sides of rock fragments; 1 percent cobbles and 60 percent pebbles from mixed pyroclastic and calcareous sedimentary rocks; abrupt wavy boundary. (Unit $\mathrm{Y}$ and sample $05^{*}$ )

2Ck2 65.4 to 88.2 in. (166 to $224 \mathrm{~cm})$. Pale brown (10YR6/3) gravelly sand with several discontinuous strata of extremely gravelly coarse sand, dark yellowishbrown (10YR4/4) moist; single grain with prominent relict bedding; loose, nonsticky and nonplastic; trace of fine roots; Stage I- carbonate development; few thin carbonate coatings on undersides of rock fragments; few thin paleocarbonate coatings on sides of rock fragments; average of 1 percent cobbles and 20 percent pebbles from mixed pyroclastic and calcareous sedimentary rocks; abrupt wavy boundary. (Unit Y and sample 06*) 
3Bkb $\quad 88.2$ to 94.1 in. (224 to $239 \mathrm{~cm}$ ). Pink (7.5YR7/4) very gravelly sandy loam, strong brown (7.5YR5/6) moist; moderate medium subangular blocky structure; slightly hard, friable, nonsticky and nonplastic; trace of fine roots; Stage I+ carbonate development; few thin carbonate coatings and common thin pendants on undersides of rock fragments; few thin paleocarbonate coatings on sides of rock fragments; 2 percent cobbles and 35 percent pebbles dominantly from mixed pyroclastic and calcareous sedimentary rocks; abrupt wavy boundary. (Unit X2 and sample $07^{*}$ )

3BCkb 94.1 to $118.1 \mathrm{in}$. (239 to $300 \mathrm{~cm})$. Pale brown (10YR6/3) extremely gravelly sand, dark yellowish- brown (10YR4/4) moist; single grain with faint relict bedding; soft, very friable, nonsticky and nonplastic; trace of fine roots; very few thin silica cutans on undersides of rock fragments; Stage I- carbonate development; irregular discontinuous 3-cm weakly carbonate-cemented lenses throughout; common thin paleocarbonate coatings on sides of rock fragments; 2 percent cobbles and 60 percent pebbles dominantly from mixed pyroclastic and calcareous sedimentary rocks. (Unit X2 and sample $08^{*}$ )

NOTES: Bench break at 51.2 in. $(130 \mathrm{~cm})$. Location was determined by triangulation using surveyed reference stakes and is accurate to within 0.25 feet $(0.08$ meters). Elevation was determined from surveyed reference elevations and is accurate to within 0.1 feet ( 0.03 meters). Diagnostic features include an ochric epipedon 0 to $3.94 \mathrm{in}$. $(0$ to $10 \mathrm{~cm})$ and argillic horizon 3.94 to $8.66 \mathrm{in}$. (10 to $22 \mathrm{~cm}$ ). The thickness of the eolian mantle in this pedon is $3.94 \mathrm{in}$. (10 $\mathrm{cm})$. The argillic horizon contains 3 percent or more clay than the original $\mathrm{C}$ horizon parent material is presumed to have contained. The $2 \mathrm{Ck} 2$ horizon is highly stratified to allow further subdivision. 


\section{SOIL PROFILE ST02-P05}

Location: Soil Trench 2, Profile 5, located 155.8 feet (47.5 meters) from northwest stake along trench wall of fan piedmont on east side of Yucca Flat upslope from NTS Area 3 RWMS; Nevada State Plane coordinates 843032.5 feet north and 691569.7 feet east; 4127.4 feet (1258.0 meters) elevation.

Described by: R. D. Van Remortel

Sampled by: Not sampled

Date described / Sampled: 7 November 1996 / Not sampled

Geomorphic surface: S4

Taxonomic classification of uppermost deposit: Haplocambid (in Unit D*)

Taxonomic classification of pedon: Sandy-skeletal, mixed, thermic Typic Haplocambids

Remarks: Matrix colors are for crushed and smoothed hand samples, while colors of surface features and concentrations are for undisturbed samples. All colors are for dry conditions unless noted otherwise. The textures given are field-determined.

\section{DESCRIPTION}

A1 0 to 0.8 in. (0 to $2 \mathrm{~cm})$. Light yellowish-brown (10YR6/4) very gravelly sandy loam, dark yellowish-brown (10YR4/4) moist; moderate coarse prismatic structure parting to moderate medium granular; soft, very friable, nonsticky and nonplastic; few fine roots; common very fine vesicular pores; common moderately thick paleocarbonate coatings on sides of rock fragments; 2 percent cobbles and 35 percent pebbles from mixed pyroclastic and calcareous sedimentary rocks; abrupt smooth boundary. (Unit Y)

A2 0.8 to $7.1 \mathrm{in}$. (2 to $18 \mathrm{~cm})$. Very pale brown $(10 \mathrm{YR} 7 / 3)$ gravelly sandy loam, yellowish-brown (10YR5/4) moist; moderate coarse prismatic structure parting to moderate thin platy; slightly hard, friable, nonsticky and slightly plastic; trace of fine roots; many fine vesicular pores; *few thin silica cutans on undersides of plates; few thin paleocarbonate coatings on sides of rock fragments; 15 percent pebbles from mixed pyroclastic and calcareous sedimentary rocks; abrupt wavy boundary. (Unit Y) 
2Bk1 7.1 to 12.6 in. (18 to $32 \mathrm{~cm}$ ). Light brown (7.5YR6/4) gravelly sandy loam, strong brown (7.5YR4/6) moist; weak medium subangular blocky structure; soft, very friable, nonsticky and nonplastic; common fine and medium roots; few fine interstitial pores; Stage I carbonate development; few very fine soft carbonate masses and common thin carbonate coatings on undersides of rock fragments; few thin paleocarbonate coatings on sides of rock fragments; 5 percent cobbles and 20 percent pebbles from mixed pyroclastic and calcareous sedimentary rocks; clear wavy boundary. (Unit Y)

2Bk2 12.6 to $22.0 \mathrm{in}$. (32 to $56 \mathrm{~cm}$ ). Light brown (7.5YR6/3) very gravelly loamy sand, brown (7.5YR5/4) moist; weak coarse subangular blocky structure; soft, very friable, nonsticky and nonplastic; common medium and coarse roots; Stage Icarbonate development; few thin carbonate coatings on undersides of rock fragments; few thin paleocarbonate coatings on sides of rock fragments; 2 percent cobbles and 40 percent pebbles from mixed pyroclastic and calcareous sedimentary rocks; gradual wavy boundary. (Unit Y)

2BCk 22.0 to 29.1 in. (56 to $74 \mathrm{~cm}$ ). Pale brown (10YR6/3) very gravelly coarse sand, dark yellowish- brown (10YR4/6) moist; single grain with faint relict bedding; soft, very friable, nonsticky and nonplastic; few medium roots; very few thin silica cutans on undersides of rock fragments; Stage I- carbonate development; few thin carbonate coatings and pendants on undersides of rock fragments; common thin paleocarbonate coatings on sides of rock fragments; 1 percent cobbles and 35 percent pebbles from mixed pyroclastic and calcareous sedimentary rocks; gradual wavy boundary. (Unit Y)

2Ck 29.1 to 39.4 in. (74 to $100 \mathrm{~cm}$ ). Pale brown (10YR6/3) very gravelly coarse sand with few discontinuous strata of gravelly sand, dark yellowish-brown (10YR4/4) moist; single grain with prominent relict bedding; soft, very friable, nonsticky and nonplastic; few medium roots; very few thin silica cutans on undersides of rock fragments; Stage I- carbonate development; few thin pendants on undersides of rock fragments; common thin paleocarbonate coatings on sides of rock fragments; 1 percent cobbles and 35 percent pebbles from mixed pyroclastic and calcareous sedimentary rocks. (Unit Y)

NOTES: Location was determined by triangulation using surveyed reference stakes and is accurate to within 0.25 feet $(0.08$ meters). Elevation was determined from surveyed reference elevations and is accurate to within 0.1 feet ( 0.03 meters). Diagnostic features include an ochric epipedon 0 to 7.09 in. (0 to $18 \mathrm{~cm}$ ) and cambic horizon 7.09 to $22.05 \mathrm{in}$. (18 to $56 \mathrm{~cm}$ ). 


\section{SOIL PROFILE ST02-P06}

Location: $\quad$ Soil Trench 2, Profile 6, located 214.6 feet (65.4 meters) from northwest stake along trench wall of fan piedmont on east side of Yucca Flat upslope from NTS Area 3 RWMS; Nevada State Plane coordinates 843004.6 feet north and 691621.4 feet east; 4126.5 feet (1257.8 meters) elevation.

Described by: R. D. Van Remortel

Sampled by: R. D. Van Remortel

Date described / sampled: 14 November 1996/4 February 1997

Geomorphic surface: S5a

Taxonomic classification of uppermost deposit: Haplocambid (in Unit C)

Taxonomic classification of pedon: Sandy*, mixed, thermic Typic Haplocambids

Remarks: Matrix colors are for crushed and smoothed hand samples, while colors of surface features and concentrations are for undisturbed samples. All colors are for dry conditions unless noted otherwise. The textures given are field-determined.

\section{DESCRIPTION}

A1 0 to 1.6 in. (0 to $4 \mathrm{~cm})$. Brown $(10 \mathrm{YR} 5 / 3)$ gravelly fine sandy loam, dark yellowish-brown (10YR3/4) moist; weak coarse prismatic structure parting to moderate thin platy and weak medium granular; soft, very friable, nonsticky and nonplastic; few very fine roots; few fine vesicular pores; few thin paleocarbonate coatings on sides of rock fragments; 1 percent cobbles and 30 percent pebbles from mixed pyroclastic and calcareous sedimentary rocks; clear wavy boundary. (Unit Y and sample 01a*)

A2 1.6 to 4.3 in. (4 to $11 \mathrm{~cm}$ ). Brown (10YR5/3) gravelly coarse sandy loam, dark yellowish-brown (10YR4/4) moist; weak coarse prismatic structure parting to moderate thin platy and weak fine granular; slightly hard, friable, nonsticky and nonplastic; few fine roots; common fine vesicular pores; few thin paleocarbonate coatings on sides of rock fragments; 20 percent pebbles from mixed pyroclastic and calcareous sedimentary rocks; abrupt wavy boundary. (Unit Y and sample $\left.01 b^{*}\right)$ 
4.3 to 9.1 in. (11 to $23 \mathrm{~cm}$ ). Light brown (7.5YR6/3) gravelly loamy coarse sand, brown (7.5YR4/4) moist; weak fine subangular blocky structure; slightly hard, friable, nonsticky and nonplastic; common fine and medium roots; few very fine vesicular pores; very few thin carbonate coatings on undersides of rock fragments; few thin paleocarbonate coatings on sides of rock fragments; 15 percent pebbles from mixed pyroclastic and calcareous sedimentary rocks; abrupt wavy boundary. (Unit $Y$ and sample $02 \mathrm{a}^{*}$ )

BA 9.1 to 11.8 in. $(23$ to $30 \mathrm{~cm})$. Light brown $(7.5 \mathrm{YR} 6 / 3)$ very gravelly loamy coarse sand, brown (7.5YR5/4) moist; weak fine subangular blocky structure; slightly hard, friable, nonsticky and nonplastic; common fine and medium roots; very few thin carbonate coatings on undersides of rock fragments; few thin paleocarbonate coatings on sides of rock fragments; 35 percent pebbles from mixed pyroclastic and calcareous sedimentary rocks; abrupt wavy boundary. (Unit $\mathrm{Y}$ and sample $\left.02 b^{*}\right)$

Bk1 11.8 to 24.4 in. (30 to $62 \mathrm{~cm})$. Pink ( 7.5 YR7/3) very gravelly loamy coarse sand, strong brown (7.5YR5/6) moist; weak medium subangular blocky structure, very faint relict bedding in parts; slightly hard, friable, nonsticky and nonplastic; few medium and coarse roots; Stage I carbonate development; common thin carbonate coatings on undersides of rock fragments; very few thin paleocarbonate coatings on sides of rock fragments; 1 percent cobbles and 50 percent pebbles from mixed pyroclastic and calcareous sedimentary rocks; gradual wavy boundary. (Unit Y and sample $03^{*}$ )

Bk2 24.4 to 32.3 in. (62 to $83 \mathrm{~cm}$ ). Pink (7.5YR7/4) gravelly loamy sand, strong brown (7.5YR4/6) moist; weak coarse subangular blocky structure, single grain with very faint relict bedding in parts; soft, very friable, nonsticky and nonplastic; common fine roots; very few thin silica cutans on undersides of rock fragments; Stage I- carbonate development; common thin carbonate coatings on undersides of rock fragments; few thin paleocarbonate coatings on sides of rock fragments; 1 percent cobbles and 20 percent pebbles from mixed pyroclastic and calcareous sedimentary rocks; gradual wavy boundary. (Unit $\mathrm{Y}$ and sample $04^{*}$ )

BCk $\quad 32.3$ to 47.6 in. ( 83 to $121 \mathrm{~cm}$ ). Pink (7.5YR7/4) gravelly sand with few thin discontinuous strata of very gravelly coarse sand, strong brown (7.5YR4/6) moist; single grain within faint relict bedding; soft, very friable, nonsticky and nonplastic; common very fine roots; very few thin silica cutans on undersides of rock fragments; Stage I- carbonate development; common thin carbonate coatings on undersides of rock fragments; few thin paleocarbonate coatings on sides of rock fragments; 1 percent cobbles and 20 percent pebbles from mixed pyroclastic and calcareous sedimentary rocks; gradual wavy boundary. (Unit $\mathrm{Y}$ and sample $\left.05^{*}\right)$ 
Ck $\quad 47.6$ to $113.8 \mathrm{in}$. (121 to $289 \mathrm{~cm})$. Very pale brown (10YR7/3) and reddishyellow (7.5YR7/6) extremely gravelly coarse sand with several thin discontinuous strata of gravelly sand, yellowish-brown (10YR5/6) and strong brown (7.5YR4/6) moist; single grain within distinct relict bedding; loose, nonsticky and nonplastic; few fine and medium roots; very few thin silica cutans on undersides of rock fragments; Stage I carbonate development; 10 percent very weakly carbonatecemented, with common thin carbonate coatings and few thin pendants on undersides of rock fragments; common thin paleocarbonate coatings on sides of rock fragments; trace of stones, 5 percent cobbles, and 55 percent pebbles from mixed pyroclastic and calcareous sedimentary rocks; abrupt wavy boundary. (Unit Y and no sample collected)

2Btkmb 113.8 to 122.0 in. (289 to $310 \mathrm{~cm}$ ). Pink (5YR7/4) very gravelly loamy sand, yellowish-red (5YR5/6) moist; moderate fine and medium subangular blocky structure; extremely hard, slightly rigid, nonsticky and nonplastic; few thin argillans on contacts between peds and fine pebbles; common thin reddish-yellow (7.5YR7/8, 5/6 moist) silica cutans on sides of rock fragments; Stage III carbonate development; discontinuous $1-\mathrm{mm}$ carbonate lamina capping horizon; 95 percent strongly carbonate-cemented with many thin carbonate coatings and common moderately thick pendants on undersides of rock fragments; few thin paleocarbonate coatings on sides of rock fragments; 2 percent cobbles and 35 percent pebbles dominantly from mixed pyroclastic and calcareous sedimentary rocks. (Unit X2 and no sample collected)

NOTES: Bench break at 59.05 in. $(150 \mathrm{~cm})$. Location was determined by triangulation using surveyed reference stakes and is accurate to within 0.25 feet $(0.08$ meters). Elevation was determined from surveyed reference elevations and is accurate to within 0.1 feet ( 0.03 meters). Diagnostic features include an ochric epipedon 0 to $4.33 \mathrm{in}$. (0 to $11 \mathrm{~cm})$ and cambic horizon 11.81 to $32.68 \mathrm{in}$. (30 to $83 \mathrm{~cm}$ ). The Ck horizon is highly stratified. 


\section{SOIL PROFILE ST02-P07}

Location: $\quad$ Soil Trench 2, Profile 7, located 259.5 feet (79.1 meters) from northwest stake along trench wall of fan piedmont on east side of Yucca Flat upslope from NTS Area 3 RWMS; Nevada State Plane coordinates 842983.2 feet north and 691661.0 feet east; 4127.0 feet (1257.9 meters) elevation.

Described by: R. D. Van Remortel

Sampled by: Not sampled

Date described / Sampled: 14 November 1996 / Not sampled

Geomorphic surface: S5a

Taxonomic classification of uppermost deposit: Haplocambid (in Unit D)

Taxonomic classification of pedon: Sandy-skeletal*, mixed, thermic Typic Haplocambids

Remarks: Matrix colors are for crushed and smoothed hand samples, while colors of surface features and concentrations are for undisturbed samples. All colors are for dry conditions unless noted otherwise. The textures given are field-determined.

\section{DESCRIPTION}

A1 0 to 1.6 in. (0 to $4 \mathrm{~cm})$. Pale brown $(10 \mathrm{YR} 6 / 3)$ gravelly sandy loam, dark yellowish-brown (10YR3/4) moist; weak coarse prismatic structure parting to weak thin platy and weak fine granular; soft, very friable, nonsticky and nonplastic; few very fine roots; few very fine vesicular pores; common thin paleocarbonate coatings on sides of rock fragments; 30 percent pebbles from mixed pyroclastic and calcareous sedimentary rocks; abrupt smooth boundary. (Unit Y)

A2 1.6 to 3.9 in. (4 to $10 \mathrm{~cm})$. Pale brown (10YR6/3) sandy loam, dark yellowishbrown (10YR4/4) moist; weak coarse prismatic structure parting to moderate thin and medium platy; slightly hard, friable, nonsticky and nonplastic; few fine roots; few very fine vesicular pores; ${ }^{*}$ few thin silica cutans on undersides of rock fragments; common thin paleocarbonate coatings on sides of rock fragments; 10 percent pebbles from mixed pyroclastic and calcareous sedimentary rocks; abrupt wavy boundary. (Unit Y) 
Bk1 3.9 to 9.4 in. (10 to $24 \mathrm{~cm}$ ). Light yellowish-brown (10YR6/4) sandy loam, dark yellowish-brown (10YR4/6) moist; weak fine and medium subangular blocky structure; slightly hard, friable, nonsticky and nonplastic; few very fine roots; Stage I- carbonate development; few thin carbonate coatings on undersides of rock fragments; few thin paleocarbonate coatings on sides of rock fragments; 10 percent pebbles from mixed pyroclastic and calcareous sedimentary rocks; clear wavy boundary. (Unit Y)

Bk2 9.4 to 14.1 in. (24 to $36 \mathrm{~cm}$ ). Light yellowish-brown (10YR6/4) gravelly sandy loam, yellowish-brown (10YR5/6) moist; weak fine and medium subangular blocky structure; soft, very friable, nonsticky and nonplastic; common medium and coarse roots; Stage I- carbonate development; few thin carbonate coatings on undersides of rock fragments; 20 percent pebbles from mixed pyroclastic and calcareous sedimentary rocks; clear wavy boundary. (Unit Y)

Bk3 14.1 to 24.4 in. (36 to $62 \mathrm{~cm}$ ). Pink $(7.5 \mathrm{YR} 7 / 3$ ) gravelly sandy loam, brown (7.5YR5/4) moist; weak coarse subangular blocky structure; soft, very friable, nonsticky and nonplastic; common fine and medium roots; very few thin silica cutans on undersides of rock fragments; Stage I carbonate development; common thin carbonate coatings and few thin pendants on undersides of rock fragments; 25 percent pebbles from mixed pyroclastic and calcareous sedimentary rocks; gradual wavy boundary. (Unit Y)

BCK 24.4 to 40.2 in. (62 to $102 \mathrm{~cm}$ ). Very pale brown (10YR7/3) gravelly loamy sand with few discontinuous strata of very gravelly coarse sand, yellowish-brown (10YR5/6) moist; single grain with very faint relict bedding; soft, very friable, nonsticky and nonplastic; few fine roots; very few thin silica cutans on undersides of rock fragments; Stage I- carbonate development; common thin carbonate coatings and pendants on undersides of rock fragments; 25 percent pebbles from mixed pyroclastic and calcareous sedimentary rocks; abrupt wavy boundary. (Unit Y)

Ck 40.2 to 45.7 in. (102 to $116 \mathrm{~cm})$. Pink $(7.5$ YR7/3) very gravelly coarse sand, strong brown (7.5YR5/6) moist; single grain within faint relict bedding; slightly hard, friable, nonsticky and nonplastic; few fine roots; Stage II- carbonate development; discontinuous 1-mm carbonate lamina throughout; 20 percent weakly carbonate-cemented with common thin carbonate coatings and pendants on undersides of rock fragments; common thin paleocarbonate coatings on sides of rock fragments; 5 percent cobbles and 45 percent pebbles dominantly from mixed pyroclastic and calcareous sedimentary rocks; clear wavy boundary. (Unit Y) 
Btqkb 45.7 to 50.4 in. (116 to $128 \mathrm{~cm}$ ). Light reddish-brown $(5 \mathrm{YR} 6 / 3)$ gravelly sandy loam, reddish-brown (5YR4/4) moist; moderate fine and medium subangular blocky structure; hard, firm, nonsticky and nonplastic; few fine roots; common thin silica cutans on undersides of ped faces and rock fragments; Stage I+ carbonate development; discontinuous 1-mm carbonate lamina throughout; 10 percent very weakly carbonate-cemented, with common carbonate filaments and common thin carbonate coatings on undersides of ped faces and rock fragments; few thin paleocarbonate coatings on sides of rock fragments; 2 percent cobbles and 30 percent pebbles dominantly from mixed pyroclastic and calcareous sedimentary rocks; clear wavy boundary. (Unit Y)

BCkb $\quad 50.4$ to 62.2 in. (128 to $158 \mathrm{~cm})$. Pinkish-white $(7.5 \mathrm{YR} 8 / 2)$ very gravelly loamy sand, strong brown (7.5YR5/6) moist; single grain within faint relict bedding; slightly hard, friable, nonsticky and nonplastic; common fine and medium roots; very few thin silica cutans on undersides of rock fragments; Stage II- carbonate development; discontinuous 1-mm carbonate lamina throughout; 60 percent very weakly carbonate-cemented with few thin carbonate coatings and common moderately thick pendants on undersides of rock fragments; few thin paleocarbonate coatings on sides of rock fragments; 2 percent cobbles and 45 percent pebbles dominantly from mixed pyroclastic and calcareous sedimentary rocks; abrupt wavy boundary. (Unit Y)

2Bkmb $\quad 62.2$ to 72.8 in. (158 to $185 \mathrm{~cm})$. Pink (7.5YR7/3) very gravelly loamy sand, strong brown (7.5YR5/6) moist; moderate fine subangular blocky structure; extremely hard, slightly rigid, nonsticky and nonplastic; trace of fine roots; very few thin argillans on contacts between peds and fine pebbles; Stage III carbonate development; nearly continuous 1-mm carbonate lamina capping horizon; 90 percent strongly carbonate-cemented with many thin carbonate coatings and pendants on undersides of rock fragments; 35 percent pebbles dominantly from mixed pyroclastic and calcareous sedimentary rocks; clear wavy boundary. (Unit $\mathrm{X} 2$ )

2Bkb $\quad 72.8$ to 82.3 in. (185 to $209 \mathrm{~cm})$. Pink (7.5YR7/3) very gravelly loamy sand, brown (7.5YR5/4) moist; weak medium subangular blocky structure, single grain with very faint relict bedding in pockets at base of horizon; very hard, very firm, nonsticky and nonplastic; trace of fine roots; very few thin silica cutans on undersides of rock fragments; Stage II carbonate development; 70 percent weakly carbonate-cemented with many thin carbonate coatings and pendants on undersides of rock fragments; 2 percent cobbles and 40 percent pebbles dominantly from mixed pyroclastic and calcareous sedimentary rocks; abrupt wavy boundary. (Unit X2)

3Bkmb 82.3 to $90.6 \mathrm{in}$. (209 to $230 \mathrm{~cm})$. Pink (7.5YR7/3) very gravelly loamy sand, reddish-yellow (7.5YR6/6) moist; moderate fine subangular blocky structure; extremely hard, slightly rigid, nonsticky and nonplastic; very few thin argillans on contacts between peds and fine pebbles; Stage III carbonate development; 90 percent strongly carbonate-cemented with common thin carbonate coatings 
and pendants on undersides of rock fragments; 35 percent pebbles dominantly from mixed pyroclastic and calcareous sedimentary rocks; clear wavy boundary. (Unit W2)

3Bkb 90.6 to 96.5 in. (230 to $245 \mathrm{~cm}$ ). Pink ( 7.5 YR7/3) very gravelly sand, strong brown (7.5YR5/6) moist; weak medium subangular blocky structure; hard, firm, nonsticky and nonplastic; Stage II- carbonate development; 30 percent weakly carbonate-cemented with common thin carbonate coatings and common moderately thick pendants on undersides of rock fragments; 50 percent pebbles dominantly from mixed pyroclastic and calcareous sedimentary rocks; abrupt wavy boundary. (Unit W2)

3B' kmb 96.5 to 108.3 in. (245 to $275 \mathrm{~cm})$. Pinkish-white $(7.5 Y R 8 / 2)$ very gravelly loamy sand, light brown (7.5YR6/4) moist; moderate fine subangular blocky structure; very hard, very firm, nonsticky and nonplastic; Stage III+ carbonate development; pink (7.5YR7/4, 6/4 moist) 2-mm carbonate lamina capping horizon and discontinuous 1-mm lamina recurring along major lateral fractures throughout; 95 percent strongly carbonate-cemented with common moderately thick carbonate coatings and pendants on undersides of rock fragments; 55 percent pebbles dominantly from mixed pyroclastic and calcareous sedimentary rocks; clear wavy boundary. (Unit W2)

3B'kb $\quad 108.3$ to 117.0 in. (275 to $297 \mathrm{~cm})$. Pink $(7.5 Y R 7 / 3)$ very gravelly loamy sand, strong brown (7.5YR5/6) moist; weak coarse subangular blocky structure; slightly hard, friable, nonsticky and nonplastic; Stage I+ carbonate development; common moderately thick pendants on undersides of rock fragments; 5 percent cobbles and 40 percent pebbles dominantly from mixed pyroclastic and calcareous sedimentary rocks; abrupt wavy boundary. (Unit W2)

3B"'kmb $\quad 117.0$ to 128.0 in. (297 to $325 \mathrm{~cm})$. Pink $(7.5 Y R 7 / 3)$ very gravelly loamy sand, strong brown (7.5YR5/6) moist; weak coarse subangular blocky structure; hard, friable, nonsticky and nonplastic; Stage IV- carbonate development; continuous 4$\mathrm{mm}$ carbonate lamina capping horizon; upper $3 \mathrm{~cm}$ is strongly cemented and remainder of horizon is 95 percent moderately carbonate-cemented with common thin carbonate coatings and pendants on undersides of rock fragments; 2 percent cobbles and 45 percent pebbles dominantly from mixed pyroclastic and calcareous sedimentary rocks. (Unit W2)

NOTES: Bench break at 59.05 in. $(150 \mathrm{~cm})$. Location was determined by triangulation using surveyed reference stakes and is accurate to within 0.25 feet ( 0.08 meters). Elevation was determined from surveyed reference elevations and is accurate to within 0.1 feet ( 0.03 meters). Diagnostic features include an ochric epipedon 0 to $3.94 \mathrm{in}$. (0 to $10 \mathrm{~cm}$ ), cambic horizon 3.94 to $24.41 \mathrm{in.} \mathrm{(10} \mathrm{to} 62 \mathrm{~cm}$ ), and petrocalcic horizon 62.2 to $72.8 \mathrm{in}$. (158 to $185 \mathrm{~cm}$ ). 


\title{
SOIL TRENCH 3 - ST03-P01 AND ST03-P02
}

\author{
SOIL PROFILE ST03-P01
}

Location: $\quad$ Soil Trench 3, Profile 1, located 116.8 feet (35.6 meters) from northwest stake along trench wall inside NTS Area 3 RWMS facility; Nevada State Plane coordinates 835060.9 feet north and 688567.3 feet east; 4012.9 feet (1223.1 meters) elevation.

Described by: R. D. Van Remortel

Sampled by: R. D. Van Remortel

Date described / sampled: 9 December 1996 / 28 January 1997

Geomorphic surface: Disturbed / Not determined

Taxonomic classification of uppermost deposit: Haplocambid (in Unit *)

Taxonomic classification of pedon: Coarse-loamy, mixed, thermic Typic Haplocambids

Remarks: Matrix colors are for crushed and smoothed hand samples, while colors of surface features and concentrations are for undisturbed samples. All colors are for dry conditions unless noted otherwise. The textures given are field-determined.

\section{DESCRIPTION}

Overburden 4.7 to 0 in. (12 to $0 \mathrm{~cm}$ ). Cover produced by excavation of trench. (not sampled)

Ap1 0 to $1.6 \mathrm{in.}$ ( 0 to $4 \mathrm{~cm})$. Pale brown $(10 \mathrm{YR} 6 / 3)$ sandy loam, dark yellowish-brown (10YR4/4) moist; massive with platy and granular appearance; soft, very friable, nonsticky and nonplastic; common very fine roots; few very fine interstitial pores; few thin paleocarbonate coatings on sides of rock fragments; 5 percent pebbles from mixed pyroclastic and calcareous sedimentary rocks; abrupt wavy boundary. (Spoil and sample 01a*)

Ap2 1.6 to 3.5 in. (4 to $9 \mathrm{~cm}$ ). Very pale brown (10YR7/4) sandy loam, dark yellowish-brown (10YR4/6) moist; massive and slightly compacted with platy and blocky appearance; slightly hard, friable, slightly sticky and slightly plastic; common very fine roots; few very fine interstitial pores; few thin paleocarbonate coatings on sides of rock fragments; 10 percent pebbles from mixed pyroclastic and calcareous sedimentary rocks; abrupt wavy boundary. (Spoil and sample $\left.01 b^{*}\right)$ 

moist; massive and compacted with prismatic appearance; very hard, very firm, sticky and plastic; few very fine roots in matrix, many fine roots along prism faces; very few very fine vesicular pores at base of horizon; few fine soft carbonate masses and common thin carbonate coatings on undersides of rock fragments; few thin paleocarbonate coatings on sides of rock fragments; 5 percent pebbles from mixed pyroclastic and calcareous sedimentary rocks; clear wavy boundary. (Spoil and sample 02*)

BA

Bk1

Bk2

BCk1 10.2 to 14.6 in. (26 to $37 \mathrm{~cm}$ ). Pink (7.5YR7/3) loam, strong brown (7.5YR5/6) moist; weak fine and medium subangular blocky structure; slightly hard, friable, slightly sticky and plastic; few very fine roots; common very fine vesicular pores; very few thin argillans lining pores and on contacts between ped faces and fine pebbles; Stage I carbonate development; few fine soft carbonate masses and common thin carbonate coatings on undersides of rock fragments; few thin paleocarbonate coatings on sides of rock fragments; 5 percent pebbles from mixed pyroclastic and calcareous sedimentary rocks; clear wavy boundary. (N2 and sample 03*)

14.6 to 20.5 in. ( 37 to $52 \mathrm{~cm}$ ). Light yellowish-brown (10YR6/4) sandy loam, dark yellowish-brown (10YR4/6) moist; weak medium subangular blocky structure; soft, very friable, slightly sticky and slightly plastic; few very fine roots; Stage I- carbonate development; few thin carbonate coatings on undersides of rock fragments; few thin paleocarbonate coatings on sides of rock fragments; 5 percent pebbles from mixed pyroclastic and calcareous sedimentary rocks; clear wavy boundary. (N2 and sample $04^{*}$ )

20.5 to 30.3 in. (52 to $77 \mathrm{~cm}$ ). Pale brown (10YR6/3) fine sandy loam, yellowishbrown (10YR5/4) moist; weak medium subangular blocky structure; soft, very friable, slightly sticky and slightly plastic; few very fine roots; Stage I- carbonate development; few thin carbonate coatings on undersides of rock fragments; few thin paleocarbonate coatings on sides of rock fragments; 5 percent pebbles from mixed pyroclastic and calcareous sedimentary rocks; gradual wavy boundary. (N2 and sample $05^{*}$ )

30.3 to 38.2 in. (77 to $97 \mathrm{~cm}$ ). Pale brown (10YR6/3) fine sandy loam, dark yellowish-brown (10YR4/4) moist; single grain with very faint relict bedding, weak medium subangular blocky structure in parts; soft, very friable, nonsticky and nonplastic; few very fine roots; Stage I- carbonate development; common thin carbonate coatings on undersides of rock fragments; few thin paleocarbonate coatings on sides of rock fragments; 5 percent pebbles from mixed pyroclastic and calcareous sedimentary rocks; abrupt wavy boundary. (N2 and sample 06*) 
BCk2 38.2 to 47.6 in. ( 97 to $121 \mathrm{~cm}$ ). Pale brown (10YR6/3) very gravelly coarse sand, yellowish-brown (10YR5/4) moist; single grain within faint relict bedding; loose, nonsticky and nonplastic; few very fine roots; Stage I- carbonate development; common thin carbonate coatings on undersides of rock fragments; common thin paleocarbonate coatings on sides of rock fragments; 45 percent pebbles dominantly from mixed pyroclastic and calcareous sedimentary rocks; abrupt wavy boundary. (Unit N2 and sample $07^{*}$ )

BC 47.6 to 74.4 in. (121 to $189 \mathrm{~cm})$. Light yellowish-brown (10YR6/4) very fine sandy loam, dark yellowish-brown (10YR4/6) moist; massive within distinct relict bedding; soft, very friable, slightly sticky and plastic; few very fine roots; few thin paleocarbonate coatings on sides of rock fragments; 2 percent pebbles dominantly from mixed pyroclastic and calcareous sedimentary rocks; clear wavy boundary. (Unit $\mathrm{N} 2$ and sample $08^{*}$ )

BAkb $\quad 74.4$ to 84.2 in. (189 to $214 \mathrm{~cm})$. Light yellowish-brown (10YR6/4) silt loam, dark yellowish-brown (10YR4/6) moist; weak thin platy structure parting to moderate medium granular; slightly hard, friable, slightly sticky and plastic; common very fine roots; common fine vesicular pores; few carbonate filaments throughout and few thin carbonate coatings on undersides of peds and rock fragments; few thin paleocarbonate coatings on sides of rock fragments; 5 percent pebbles dominantly from mixed pyroclastic and calcareous sedimentary rocks; clear wavy boundary. (Unit N1 and sample $09^{* *}$ )

Bwb $\quad 84.2$ to 91.3 in. (214 to $232 \mathrm{~cm}$ ). Light brown (7.5YR6/4) gravelly sandy loam, strong brown (7.5YR4/6) moist; weak medium subangular blocky structure; soft, very friable, slightly sticky and slightly plastic; trace of very fine roots; few thin paleocarbonate coatings on sides of rock fragments; 15 percent pebbles dominantly from mixed pyroclastic and calcareous sedimentary rocks; abrupt wavy boundary. (Unit N1 and sample $10^{*}$ )

Btkb $\quad 91.3$ to 108.7 in. (232 to $276 \mathrm{~cm}$ ). Light brown (7.5YR6/4) gravelly loam, strong brown (7.5YR5/6) moist; moderate coarse prismatic structure parting to moderate medium and coarse subangular blocky; hard, firm, slightly sticky and slightly plastic; few fine and medium roots; common thin argillans on contacts between peds and fine pebbles; Stage II carbonate development; 60 percent weakly carbonate-cemented with common carbonate filaments and common thin carbonate coatings on undersides of peds and rock fragments; 15 percent pebbles dominantly from mixed pyroclastic and calcareous sedimentary rocks; clear wavy boundary. (Unit NI and sample 11*) 
BCkb $\quad 108.7$ to 116.5 in. (276 to $296 \mathrm{~cm}$ ). Pink $(7.5 Y R 7 / 3)$ extremely gravelly sandy loam, strong brown (7.5YR5/6) moist; single grain within very faint relict bedding, weak medium subangular blocky structure in parts; slightly hard, friable, nonsticky and nonplastic; Stage II- carbonate development; 30 percent very weakly carbonate-cemented with common discontinuous carbonate zones; common moderately thick pendants and common thin carbonate coatings on undersides of rock fragments; few thin paleocarbonate coatings on sides of rock fragments; 65 percent pebbles dominantly from mixed pyroclastic and calcareous sedimentary rocks; gradual wavy boundary. (Unit M and sample 12*)

Ckb $\quad 116.5$ to $130.0 \mathrm{in.}$ (296 to $330 \mathrm{~cm}$ ). Light brown $(7.5$ YR6/4) extremely gravelly coarse sand, strong brown (7.5YR5/6) moist; single grain within distinct relict bedding; loose, nonsticky and nonplastic; Stage I carbonate development; few discontinuous carbonate zones; few thin pendants and carbonate coatings on undersides of rock fragments; few thin paleocarbonate coatings on sides of rock fragments; 65 percent pebbles dominantly from mixed pyroclastic and calcareous sedimentary rocks. (Unit $\mathrm{M}$ and sample $13^{*}$ )

NOTES: Bench break at 70.87 in. $(180 \mathrm{~cm})$. Location was determined by triangulation using surveyed reference stakes and is accurate to within 0.25 feet ( 0.08 meters). Elevation was determined from surveyed reference elevations and is accurate to within 0.1 feet $(0.03$ meters). Diagnostic features include a disturbed surface layer 0 to $3.54 \mathrm{in}$. (0 to $9 \mathrm{~cm})$ and cambic horizon 14.56 to 30.31 in. ( 37 to $77 \mathrm{~cm}$ ). 


\section{SOIL PROFILE ST03-P02}

Location: $\quad$ Soil Trench 3, Profile 2, located 260.8 feet (79.5 meters) from northwest stake along trench wall of fan piedmont inside NTS Area 3 RWMS facility; Nevada State Plane coordinates 835009.7 feet north and 688701.9 feet east; 4012.1 feet (1222.9 meters) elevation.

Described by: R. D. Van Remortel

Sampled by: R. D. Van Remortel

Date described / sampled: 12 December 1996 / 28 January 1997

Geomorphic surface: Disturbed / Not determined

Taxonomic classification of uppermost deposit: Haplocambid (in Unit *)

Taxonomic classification of pedon: Coarse-loamy, mixed, thermic Typic Haplocambids

Remarks: Matrix colors are for crushed and smoothed hand samples, while colors of surface features and concentrations are for undisturbed samples. All colors are for dry conditions unless noted otherwise. The textures given are field-determined.

\section{DESCRIPTION}

Overburden 2.4 to 0 in. $(6$ to $0 \mathrm{~cm})$. Cover produced by excavation of trench. (not sampled)

Ap1 0 to $0.8 \mathrm{in}$. (0 to $2 \mathrm{~cm})$. Pale brown (10YR5/3) gravelly sandy loam, dark yellowish-brown (10YR3/4) moist; massive with granular appearance; soft, very friable, nonsticky and nonplastic; common fine roots; few fine interstitial pores; few thin paleocarbonate coatings on sides of rock fragments; 1 percent cobbles and 20 percent pebbles from mixed pyroclastic and calcareous sedimentary rocks; abrupt broken boundary. (Spoil and sample 01a*)

Ap2 0.8 to 4.3 in. (2 to $11 \mathrm{~cm})$. Very pale brown $(10 \mathrm{YR} 6 / 3)$ sandy loam, dark yellowish-brown (10YR4/4) moist; massive and slightly compacted with platy appearance; slightly hard, friable, slightly sticky and slightly plastic; few fine roots; few fine tubular pores; few thin paleocarbonate coatings on sides of rock fragments; 10 percent pebbles from mixed pyroclastic and calcareous sedimentary rocks; abrupt wavy boundary. (Spoil and sample 01b*) 
Ap3

Ap4

Ap5

BA

Bk1

Bk2
4.3 to 6.3 in. (11 to $16 \mathrm{~cm}$ ). Pink (7.5YR7/3) sandy loam, brown (7.5YR5/4) moist; massive and compacted with blocky and granular appearance; hard, firm, slightly sticky and slightly plastic; few very fine roots; very few very fine tubular pores; 5 percent pebbles from mixed pyroclastic and calcareous sedimentary rocks; abrupt wavy boundary. (Spoil and sample 01c*)

6.3 to 7.5 in. (16 to $19 \mathrm{~cm})$. Light brown (7.5YR6/3) gravelly loamy coarse sand, strong brown (7.5YR4/6) moist; massive with blocky appearance; soft, very friable, slightly sticky and plastic; few very fine roots; few very fine tubular pores; few thin paleocarbonate coatings on sides of rock fragments; 15 percent pebbles from mixed pyroclastic and calcareous sedimentary rocks; abrupt wavy boundary. (Spoil and sample 01d*)

7.5 to 15.4 in. (19 to $39 \mathrm{~cm}$ ). Light brown (7.5YR6/4) sandy loam, strong brown (7.5YR4/6) moist; massive and compacted with prismatic appearance; hard, firm, slightly sticky and plastic; few very fine roots in matrix, many very fine roots along prism faces; few very fine vesicular pores at base of horizon; few fine soft carbonate masses and few thin carbonate coatings on undersides of rock

fragments; 5 percent pebbles from mixed pyroclastic and calcareous sedimentary rocks; clear wavy boundary. (Spoil and sample 02*)

15.4 to 21.3 in. (39 to $54 \mathrm{~cm}$ ). Pink (7.5YR7/4) loam, strong brown (7.5YR5/6) moist; weak thin platy structure parting to weak fine and medium subangular blocky; slightly hard, friable, sticky and plastic; few very fine roots; common very fine vesicular pores; very few thin argillans lining pores and on contacts between ped faces and fine pebbles; common thin carbonate coatings on undersides of peds and rock fragments; 10 percent pebbles from mixed pyroclastic and calcareous sedimentary rocks; clear wavy boundary. (Unit N2 and sample $03^{*}$ )

21.3 to 29.1 in. (54 to $74 \mathrm{~cm}$ ). Light brown (7.5YR6/4) gravelly sandy loam, strong brown (7.5YR5/6) moist; weak medium subangular blocky structure; soft, very friable, slightly sticky and slightly plastic; trace of very fine roots; Stage Icarbonate development; few thin carbonate coatings on undersides of rock fragments; 20 percent pebbles from mixed pyroclastic and calcareous sedimentary rocks; gradual wavy boundary. (Unit N2 and sample 04*)

29.1 to 37.4 in. (74 to $95 \mathrm{~cm}$ ). Light brown (7.5YR6/4) gravelly loamy sand, dark brown (7.5YR4/4) moist; weak coarse subangular blocky structure; soft, very friable, nonsticky and nonplastic; trace of very fine roots; Stage I- carbonate development; few thin carbonate coatings on undersides of rock fragments; 30 percent pebbles from mixed pyroclastic and calcareous sedimentary rocks; abrupt wavy boundary. (Unit N2 and sample $05^{*}$ ) 
BCk1 37.4 to $46.1 \mathrm{in.} \mathrm{(95} \mathrm{to} 117 \mathrm{~cm}$ ). Pink (7.5YR7/3) and reddish-brown (5YR 5/4) extremely gravelly loamy coarse sand, brown (7.5YR5/4) and reddish-brown (5YR 4/4) moist; single grain within very faint relict bedding; soft, very friable, nonsticky and nonplastic; pockets of common very fine roots in reddish-brown zones; Stage I- carbonate development; few soft carbonate-enriched zones and common thin carbonate coatings on undersides of rock fragments; few thin paleocarbonate coatings on sides of rock fragments; 65 percent pebbles from mixed pyroclastic and calcareous sedimentary rocks; abrupt wavy boundary. (Unit N2 and sample 06*)

BCk2 46.1 to 52.8 in. (117 to $134 \mathrm{~cm})$. Light brown $(7.5 \mathrm{YR} 6 / 3)$ and reddish-brown (5YR 5/4) very gravelly coarse sand, brown (7.5YR5/4) and reddish-brown (5YR 4/4) moist; single grain with faint relict bedding; loose, nonsticky and nonplastic; pockets of common very fine roots in reddish-brown zones; Stage I- carbonate development; few thin carbonate coatings on undersides of rock fragments; few thin paleocarbonate coatings on sides of rock fragments; 45 percent pebbles from mixed pyroclastic and calcareous sedimentary rocks; abrupt wavy boundary. (Unit N2 and sample $07 *$ )

BCk3 52.8 to 64.2 in. (134 to $163 \mathrm{~cm})$. Light brown (7.5YR6/4) fine sandy loam, brown (7.5YR5/4) moist; massive with very faint relict bedding; soft, very friable, slightly sticky and slightly plastic; few very fine roots; 30 percent of horizon is occupied by slightly hard subangular blocks of older soil suspended in the matrix; blocks range from 2 to $9.8 \mathrm{in}$. ( 5 to $25 \mathrm{~cm}$ ) in diameter and have texture of very fine sandy loam; Stage I carbonate development; common thin carbonate filaments and few fine soft carbonate masses within consolidated zones; few thin paleocarbonate coatings on sides of rock fragments; 40 percent pebbles from mixed pyroclastic and calcareous sedimentary rocks; abrupt wavy boundary. (Unit N2 and sample 08*)

BCk4 64.2 to 69.3 in. (163 to $176 \mathrm{~cm})$. Pink (7.5YR7/3) very gravelly sandy loam, brown (7.5YR5/4) moist; massive within very faint relict bedding, weak coarse subangular blocky structure in parts; soft, very friable, nonsticky and nonplastic; trace of very fine roots; 10 percent of horizon is occupied by slightly hard subangular blocks of older soil suspended in the matrix; blocks range from (.79 to 3.9 in.) 2 to $10 \mathrm{~cm}$ in diameter and have texture of fine sandy loam; Stage I carbonate development; common thin carbonate coatings on undersides of rock fragments; few thin paleocarbonate coatings on sides of rock fragments; 40 percent pebbles dominantly from mixed pyroclastic and calcareous sedimentary rocks; abrupt wavy boundary. (Unit N2 and sample 09*)

BCk5 69.3 to 78.3 in. (176 to $199 \mathrm{~cm})$. Pink (7.5YR7/3) very fine sandy loam, light brown (7.5YR6/4) moist; massive within very faint relict bedding; soft, very friable, slightly sticky and plastic; few thin paleocarbonate coatings on sides of rock fragments; 1 percent pebbles dominantly from mixed pyroclastic and calcareous sedimentary rocks; clear wavy boundary. (Unit N2 and sample 10*) 
BCk6 78.3 to 82.3 in. (199 to $209 \mathrm{~cm}$ ). Light brown (7.5YR6/3) sandy loam, dark brown (10YR4/4) moist; weak medium subangular blocky structure; soft, very friable, slightly sticky and slightly plastic; few thin carbonate coatings on undersides of rock fragments; few thin paleocarbonate coatings on sides of rock fragments; 2 percent pebbles dominantly from mixed pyroclastic and calcareous sedimentary rocks; abrupt irregular boundary. (Unit N2 and sample $11^{*}$ )

BAkb $\quad 82.3$ to 90.2 in. (209 to $229 \mathrm{~cm}$ ). Light reddish-brown (5YR6/4) very fine sandy loam, yellowish-red (5YR5/6) moist; moderate coarse subangular blocky structure; hard, firm, slightly sticky and slightly plastic; common very fine roots; common very fine vesicular pores; very few thin argillans on contacts between peds and fine pebbles; Stage I carbonate development; common carbonate filaments and few fine soft carbonate masses; 10 percent pebbles dominantly from mixed pyroclastic and calcareous sedimentary rocks; clear wavy boundary. (Unit $\mathrm{N} 1$ and sample $12^{*}$ )

Bkb $\quad 90.2$ to 96.8 in. (229 to $246 \mathrm{~cm}$ ). Light brown (7.5YR6/4) coarse sandy loam, strong brown (7.5YR4/6) moist; moderate fine and medium subangular blocky structure; slightly hard, friable, slightly sticky and slightly plastic; common very fine roots; few very fine vesicular pores; very few thin argillans on contacts between peds and fine pebbles; Stage I- carbonate development; few carbonate filaments and few very fine soft carbonate masses; 10 percent pebbles dominantly from mixed pyroclastic and calcareous sedimentary rocks; clear wavy boundary. (Unit NI and sample 13*)

BCkb 96.8 to 104.0 in. (246 to $264 \mathrm{~cm}$ ). Light reddish-brown (5YR6/3) gravelly loamy sand, yellowish-red (5YR4/6) moist; weak medium subangular blocky structure, single grain within very faint relict bedding in parts; slightly hard, friable, nonsticky and nonplastic; Stage I- carbonate development; few thin carbonate filaments and few thin carbonate coatings on undersides of rock fragments; 20 percent pebbles dominantly from mixed pyroclastic and calcareous sedimentary rocks; abrupt wavy boundary. (Unit N1 and sample 14*)

Btkb 104.0 to 113.0 in. (264 to $287 \mathrm{~cm}$ ). Light brown (7.5YR6/4) gravelly sandy loam, strong brown (7.5YR5/6) moist; weak coarse prismatic structure parting to moderate medium and coarse subangular blocky; hard, firm, slightly sticky and slightly plastic; common thin argillans on contacts between peds and fine pebbles; Stage I carbonate development; common carbonate filaments and few thin carbonate coatings on undersides of rock fragments; 25 percent pebbles dominantly from mixed pyroclastic and calcareous sedimentary rocks; clear wavy boundary. (Unit $\mathrm{M}$ and sample 15*) 
B'kb $\quad 113.0$ to 118.5 in. (287 to $301 \mathrm{~cm})$. Pink (7.5YR7/3) gravelly sandy loam, strong brown (7.5YR5/6) moist; moderate fine and medium subangular blocky structure; slightly hard, friable, slightly sticky and slightly plastic; Stage I carbonate development; few carbonate filaments and common thin carbonate coatings on undersides of rock fragments; 25 percent pebbles dominantly from mixed pyroclastic and calcareous sedimentary rocks; abrupt wavy boundary. (Unit M and sample $16^{*}$ )

2Btkb 118.5 to 124.0 in. (301 to $315 \mathrm{~cm}$ ). Pink (5YR7/3) gravelly loam, reddish-brown (5YR5/4) moist; moderate medium and coarse subangular blocky structure; hard, firm, slightly sticky and slightly plastic; common thin argillans on contacts between peds and fine pebbles; Stage I carbonate development; common carbonate filaments and common thin carbonate coatings on undersides of rock fragments; 20 percent pebbles dominantly from mixed pyroclastic and calcareous sedimentary rocks; clear wavy boundary. (Unit M and sample 17*)

2Bkb $\quad 124.0$ to130.0 in. (315 to $330 \mathrm{~cm}$ ). Light reddish-brown (5YR6/4) gravelly loamy sand, yellowish-red (5YR4/6) moist; weak fine subangular blocky structure; slightly hard, friable, nonsticky and nonplastic; Stage I- carbonate development; few thin carbonate coatings on undersides of rock fragments; 30 percent pebbles dominantly from mixed pyroclastic and calcareous sedimentary rocks. (Unit M and sample $18^{*}$ )

NOTES: Bench break at 68.9 in. $(175 \mathrm{~cm})$. Location was determined by triangulation using surveyed reference stakes and is accurate to within 0.25 feet $(0.08$ meters). Elevation was determined from surveyed reference elevations and is accurate to within 0.1 feet $(0.03$ meters). Diagnostic features include a disturbed surface layer 0 to $7.5 \mathrm{in}$. (0 to $19 \mathrm{~cm})$ and cambic horizon 21.26 to 37.4 in. (54 to $95 \mathrm{~cm}$ ). 


\section{APPENDIX D}

\section{SOIL CHARACTERIZATION DATABASE}


Ths mes intentondy lef bhat 


\begin{tabular}{|c|c|c|c|c|c|c|c|c|c|c|c|c|c|c|c|c|c|c|c|c|c|c|c|}
\hline Easking $(m)$ & $\begin{array}{l}\infty \\
b \\
\infty \\
\infty\end{array}$ & $\infty$ & $\infty$ & 8 & $\infty$ & 8 & $\begin{array}{l}0 \\
0 \\
0 \\
6\end{array}$ & $\infty$ & $\infty$ & 3 & $\frac{m}{3}$ & 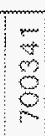 & 8 & 8 & $\frac{5}{8}$ & $\frac{9}{2}$ & $\frac{\infty}{\infty}$ & $\begin{array}{c}\infty \\
\infty \\
\infty\end{array}$ & $\begin{array}{l}9 \\
8\end{array}$ & $\frac{2}{5}$ & $\frac{5}{\infty}$ & $\frac{2}{\infty}$ & 8 \\
\hline Norting (T) & $\begin{array}{l}0 \\
b \\
\frac{8}{b}\end{array}$ & 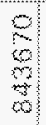 & $\infty$ & $\frac{8}{8}$ & $\infty$ & $\infty$ & $\frac{\infty}{b}$ & $\frac{\infty}{\infty}$ & $\frac{\infty}{\infty}$ & $\begin{array}{c}0 \\
\infty \\
\infty \\
0\end{array}$ & 8 & 8 & 8 & 8 & $\frac{\infty}{\infty}$ & $\infty$ & $\infty$ & $\infty$ & $\left(\begin{array}{l}x \\
\infty \\
\infty \\
\infty\end{array}\right.$ & $\frac{5}{3}$ & $\frac{\pi}{\infty}$ & $\frac{p}{b}$ & $\frac{4}{2}$ \\
\hline Ground Elevation (f) & $\frac{6}{m}$ & $\frac{\infty}{m}$ & $\frac{\infty}{\frac{m}{m}}$ & $\stackrel{s}{m}$ & $\frac{10}{4}$ & $\frac{10}{m}$ & $\frac{\infty}{x}$ & $\frac{5}{\infty}$ & $\frac{\infty}{m}$ & $\begin{array}{l}10 \\
7\end{array}$ & $\frac{6}{8}$ & $\begin{array}{l}10 \\
\frac{0}{2} \\
\frac{1}{4}\end{array}$ & 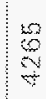 & $P_{m}$ & 8 & $\frac{8}{6}$ & $\infty$ & 8 & $\frac{8}{5}$ & 8 & $\infty$ & $\frac{8}{3}$ & 8 \\
\hline Asr-Dry Fine Earth bto $\{0\}$ & $\frac{m}{2}$ & $\frac{\infty}{m}$ & $\infty$ & 8 & $\frac{\omega}{\infty}$ & $\frac{\infty}{2}$ & $b_{\infty}^{\infty}$ & $\infty$ & 8 & 9 & 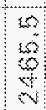 & $\begin{array}{c}\infty \\
\infty \\
\infty\end{array}$ & $\infty$ & $\infty$ & $\frac{\infty}{\alpha}$ & $\infty$ & $\infty$ & 8 & 8 & $\frac{m}{6}$ & $\infty$ & $\frac{\infty}{b}$ & 8 \\
\hline Ais-bry Sample Wt, $\{a\}$ & $\frac{\infty}{\infty}$ & $\begin{array}{l}5 \\
5 \\
+\end{array}$ & 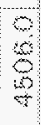 & 8 & $\frac{\infty}{\infty}$ & $\frac{6}{6}$ & $\frac{6}{0}$ & $\infty$ & $\begin{array}{c}0 \\
0 \\
0\end{array}$ & $\underset{\infty}{\infty}$ & 8 & $\begin{array}{c}\infty \\
0 \\
0 \\
0\end{array}$ & $\begin{array}{l}m \\
m \\
m\end{array}$ & 8 & $\frac{\infty}{\infty}$ & $\frac{m}{3}$ & 8 & $\begin{array}{l}2 \\
2 \\
5 \\
0\end{array}$ & $\left(\begin{array}{l}\infty \\
\infty \\
\infty\end{array}\right.$ & 8 & $\frac{m}{8}$ & ${ }_{\infty}^{\infty}$ & $\frac{b}{6}$ \\
\hline Taxture Modities - Feld & \pm & $m$ & 8 & $\underline{E}$ & $\mathrm{~m}$ & $\infty$ & 6 & $\underset{\infty}{2}$ & 0 & $\underset{\infty}{\infty}$ & $\frac{x}{0}$ & $\frac{x}{0}$ & $\frac{x}{0}$ & $\frac{2}{6}$ & $\frac{x}{0}$ & $\frac{2}{0}$ & $\frac{3}{6}$ & $\frac{2}{0}$ & $\mathbb{Z}_{0}$ & $\frac{x}{\infty}$ & 2 & $\frac{3}{c}$ & $\frac{x}{b}$ \\
\hline Soll texture - Folu & $\frac{m}{0}$ & & Din & 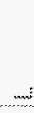 & $\infty$ & $\infty$ & $\infty$ & $t$ & 0 & $\frac{m}{5} \frac{1}{\frac{1}{2}}$ & $\infty$ & $\frac{6}{3}$ & $\sqrt{1}$ & $\infty$ & $\infty$ & $\infty$ & $w$ & $\infty$ & $\infty$ & $\infty$ & $\infty$ & $\infty$ & $t$ \\
\hline Soll Texture-Lab & $\infty$ & $\infty$ & $\infty$ & 0 & 0 & $w$ & $\infty$ & 6 & 8 & - & 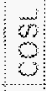 & 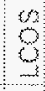 & 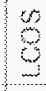 & 8 & 8 & 8 & 8 & 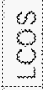 & $\infty$ & $\infty$ & $\infty$ & $\omega$ & 8 \\
\hline Geomorthio surface & $\infty$ & 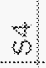 & 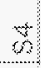 & 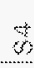 & 0 & 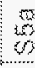 & 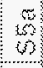 & $\infty$ & $\infty$ & 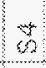 & vo & $b$ & 6 & $b$ & $\infty$ & $\infty$ & 6 & 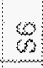 & 6 & 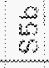 & 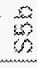 & 9 & 6 \\
\hline Lithotacies & 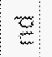 & id & $\mathrm{E}$ & 踺 & $\frac{m}{m}$ & 을 & $\frac{\infty}{m}$ & $\mathbb{W}$ & $\stackrel{0}{=}$ & $E$ & 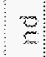 & p & $\mathbb{E}$ & ㄹ & 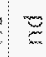 & $\bar{m}$ & p & 8 & $\mathbb{E}$ & $p$ & 8 & 8 & 8 \\
\hline Mhostativgraphe Subumi & 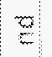 & $\ddot{p}$ & $\vec{c}$ & $\bar{m}$ & $\underset{w}{D}$ & 을 & $\Phi$ & 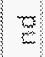 & $q$ & 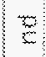 & 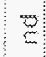 & 릴 & 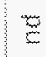 & E & $\ddot{Z}$ & $\bar{w}$ & $\underline{m}$ & 8 & $\bar{z}$ & $\bar{m}$ & E & $\bar{E}$ & 9 \\
\hline 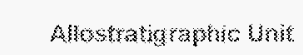 & $\mathrm{p}$ & $P$ & $\mathrm{D}$ & 를 & $\mathrm{P}$ & 8 & 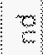 & $\mathrm{c}$ & ळ & 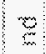 & ळ & $\mathrm{g}$ & $\mathrm{e}$ & 8 & 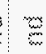 & $\Phi$ & $\infty$ & 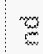 & 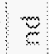 & 8 & 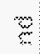 & 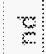 & 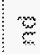 \\
\hline Profles & 8 & 8 & 8 & 8 & 8 & 8 & 8 & 8 & 8 & $\frac{1}{2}$ & 8 & 8 & $\frac{5}{2}$ & 5 & 5 & 8 & 5 & 5 & 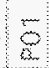 & 5 & 6 & 8 & 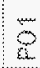 \\
\hline bocation & 8 & & 8 & 8 & 6 & 8 & $\varnothing$ & 8 & $\infty$ & 8 & 8 & $\frac{b}{x}$ & 9 & 6 & $\frac{8}{6}$ & 8 & 6 & $e_{\infty}^{\infty}$ & 8 & 8 & $\frac{6}{8}$ & 8 & 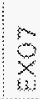 \\
\hline Lower Daptu \{cm\} & $m$ & $\mathrm{~N}$ & 3 & 8 & 8 & $\infty$ & $b_{0}$ & 3 & 8 & $m$ & 8 & 8 & $\infty$ & 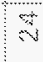 & 9 & $p+$ & 6 & 8 & \% & $\theta$ & 8 & $\infty$ & 8 \\
\hline Unper Deph \{crm\} & 0 & & m & a & 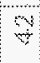 & 0 & $\infty$ & 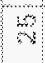 & 8 & 0 & $\infty$ & $\Leftrightarrow$ & 8 & $\infty$ & 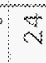 & $\infty$ & 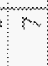 & $\infty$ & 0 & $\infty$ & $\infty$ & 8 & $\infty$ \\
\hline Memons & $\frac{2}{2}$ & $\$$ & 3 & $\underset{d}{2}$ & $\frac{3}{2}$ & $<$ & $\infty$ & 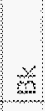 & 6 & 8 & $\frac{z}{\omega}$ & $\frac{d}{\partial}$ & w & $\frac{8}{b}$ & $\frac{a}{2}$ & 0 & 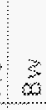 & 8 & 4 & 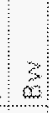 & $\frac{x}{6}$ & 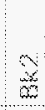 & 8 \\
\hline Fista Santrate Conde & $\frac{5}{3}$ & $\begin{array}{l}8 \\
8 \\
8 \\
6\end{array}$ & $\frac{8}{8}$ & $\frac{3}{8}$ & $\frac{8}{8}$ & $\frac{8}{8}$ & $\frac{\phi}{\partial}$ & $\frac{9}{8}$ & $\frac{8}{8}$ & $\frac{5}{3}$ & $\frac{8}{6}$ & $\frac{8}{6}$ & $\frac{8}{8}$ & $\frac{8}{8}$ & $\frac{8}{\frac{8}{6}}$ & $\frac{5}{\frac{8}{6}}$ & $\frac{8}{8}$ & $\begin{array}{l}9 \\
\frac{8}{8} \\
8 \\
8 \\
8\end{array}$ & $\frac{5}{8}$ & $\frac{8}{8}$ & $\frac{8}{8}$ & $\frac{8}{6}$ & $\frac{5}{8}$ \\
\hline Sample & $\$$ & $\infty$ & 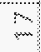 & $\Rightarrow$ & 9 & $\infty$ & 8 & 0 & 6 & 7 & 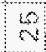 & $\frac{m}{m}$ & 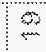 & 13 & $\omega$ & 8 & 8 & 0 & $\infty$ & $\infty$ & $\infty$ & 8 & $\Rightarrow$ \\
\hline gatch & 8 & 8 & 8 & 8 & 8 & 8 & 8 & 8 & 8 & 8 & 8 & 8 & 8 & 8 & 8 & 8 & 8 & 8 & 3 & 8 & 8 & 8 & 8 \\
\hline
\end{tabular}




\begin{tabular}{|c|c|c|c|c|c|}
\hline Easuing (th) & 8 & 8 & $\begin{array}{l}1 \\
8 \\
8\end{array}$ & 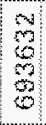 & $\begin{array}{l}0 \\
0 \\
0 \\
0 \\
0\end{array}$ \\
\hline Norting (te) & $\frac{\infty}{\infty}$ & $\infty$ & $\begin{array}{l}10 \\
0 \\
0 \\
0 \\
0\end{array}$ & $\begin{array}{l}\infty \\
\infty \\
\infty \\
\infty\end{array}$ & $\begin{array}{l}5 \\
5 \\
9 \\
0 \\
0\end{array}$ \\
\hline Ground Elevation (ft) & $\sum_{\infty}^{\infty}$ & $\frac{\infty}{4}$ & $\frac{12}{-1}$ & $\frac{9}{4}$ & $\left(\begin{array}{l}0 \\
-4 \\
7\end{array}\right.$ \\
\hline Arr-ory Fire Earth Wh $\{0\}$ & $m_{m}^{15}$ & $\begin{array}{l}\infty \\
\infty \\
\infty \\
0\end{array}$ & $\infty^{\infty}$ & $\begin{array}{l}m \\
15 \\
0 \\
0\end{array}$ & $\begin{array}{l}- \\
m \\
0 \\
7\end{array}$ \\
\hline Air Dry Sampla Wh (b) & 8 & $\begin{array}{c}\infty \\
m \\
\infty\end{array}$ & 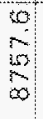 & $\frac{\infty}{p}$ & $\begin{array}{l}\omega \\
m \\
\infty \\
\infty\end{array}$ \\
\hline Texiste Modifier - Field & 8 & 5 & $\vec{a}$ & $\underset{c}{x}$ & x \\
\hline Soil Texure-Field & $\frac{\omega}{1}$ & 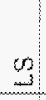 & 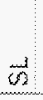 & 9 & $\infty$ \\
\hline Soll rexure - Lab & 3 & 3 & 9 & 0 & 8 \\
\hline Cannomahio Stxraces & $\infty$ & 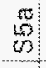 & $\begin{array}{l}6 \\
b\end{array}$ & 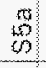 & 要 \\
\hline Lithotacise & 8 & 2 & $\mathrm{E}$ & 묘 & 항 \\
\hline 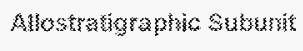 & 8 & 8 & 망 & 8 & 할 \\
\hline Alostratignanic Unit & 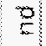 & $D$ & $\mathbb{E}$ & 일 & 8 \\
\hline Protile & 8 & 8 & 5 & 5 & 5 \\
\hline Location: & 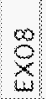 & 8 & 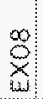 & $\underset{\mathbb{L}}{\infty}$ & $\begin{array}{c}\infty \\
8 \\
8\end{array}$ \\
\hline Lower beyth (cm) & $\infty$ & 2 & $m$ & $\overrightarrow{0}$ & 8 \\
\hline Upper Danth \{cran\} & 0 & $\infty$ & 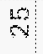 & 9 & 8 \\
\hline Honzon & $<$ & $\not{6}$ & $\bar{b}$ & $\frac{\searrow}{0}$ & 8 \\
\hline Fient Sartole Cote & $\frac{8}{8}$ & $\begin{array}{l}8 \\
8 \\
8 \\
8 \\
6\end{array}$ & 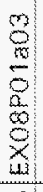 & 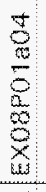 & $\frac{8}{\infty}$ \\
\hline Sampla & 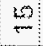 & $\infty$ & $\infty$ & $\stackrel{N}{N}$ & - \\
\hline arach & 5 & $\bar{B}$ & 8 & 8 & 8 \\
\hline
\end{tabular}




\begin{tabular}{|c|c|c|c|c|c|c|c|c|c|c|c|c|c|c|c|c|c|c|c|c|c|c|c|}
\hline Easting $(t)$ & $\begin{array}{l}\infty \\
\infty \\
\infty\end{array}$ & $\begin{array}{l}0 \\
8 \\
8\end{array}$ & $\frac{2}{2}$ & $\begin{array}{l}\infty \\
\infty \\
\infty\end{array}$ & $\begin{array}{l}\infty \\
8 \\
8\end{array}$ & $\frac{m}{m}$ & $\frac{\infty}{\infty}$ & $\left(\begin{array}{l}\infty \\
\infty \\
\infty \\
\infty\end{array}\right.$ & $\begin{array}{l}6 \\
0\end{array}$ & $\frac{\infty}{\infty}$ & $\frac{1}{2}$ & $\frac{\infty}{8}$ & $\begin{array}{l}\infty \\
0 \\
0 \\
0\end{array}$ & $\begin{array}{l}2 \\
\infty \\
\infty \\
\infty\end{array}$ & $\begin{array}{l}\frac{9}{3} \\
3 \\
3 \\
5\end{array}$ & $\frac{2}{\infty}$ & $\begin{array}{l}\frac{9}{8} \\
0 \\
0\end{array}$ & 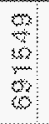 & $\frac{\infty}{\infty}$ & 部 & $\begin{array}{l}9 \\
3 \\
3\end{array}$ & $\frac{\infty}{\infty}$ & $\frac{m}{6}$ \\
\hline 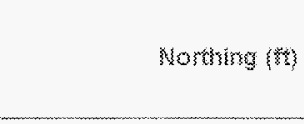 & $\begin{array}{l}5 \\
0 \\
0 \\
\infty\end{array}$ & $\underset{8}{8}$ & $\frac{8}{8}$ & $\frac{\partial}{\infty}$ & $\begin{array}{l}5 \\
\infty \\
\infty\end{array}$ & $\frac{\infty}{\infty}$ & $\frac{\infty}{\infty}$ & $\frac{8}{\infty}$ & $\begin{array}{l}b \\
\infty \\
\infty\end{array}$ & $\frac{5}{\infty}$ & $\begin{array}{l}2 \\
0 \\
0\end{array}$ & $\frac{\infty}{0}$ & $\frac{b}{\infty}$ & $\frac{5}{8}$ & $\begin{array}{l}\infty \\
\infty \\
\infty\end{array}$ & $\frac{4}{\infty}$ & $\frac{5}{b}$ & $\frac{5}{8}$ & $\frac{\infty}{\infty}$ & $\begin{array}{l}+ \\
3 \\
\infty\end{array}$ & 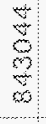 & $\frac{6}{8}$ & 9 \\
\hline Ground Elezation $(4)$ & $\frac{\infty}{\pi}$ & $\frac{\vec{w}}{\sqrt[w]{*}}$ & $\frac{\infty}{\infty}$ & $\frac{\infty}{\sim}$ & $\stackrel{\square}{\stackrel{5}{\rightleftarrows}}$ & $\frac{\infty}{m}$ & $\frac{5}{4}$ & $\frac{\infty}{4}$ & $\begin{array}{l}\infty \\
5 \\
+\end{array}$ & $\frac{\infty}{4}$ & $\frac{2 \pi}{4}$ & $\frac{\infty}{4}$ & $\frac{\infty}{\infty}$ & $\frac{\infty}{\infty}$ & $\frac{r}{\infty}$ & $\frac{\beta}{\infty}$ & $\mathrm{m}_{\dot{r}}$ & $\mathrm{~s}$ & $\frac{m}{m}$ & $\underset{\sim}{\sim}$ & $\infty$ & $\frac{n}{b}$ & a \\
\hline Ars-Dry Fine Earth Wht (9) & \begin{tabular}{l}
$\infty$ \\
+ \\
\multirow{2}{*}{}
\end{tabular} & $\stackrel{8}{8}$ & 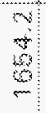 & $\begin{array}{l}\infty \\
\infty \\
\curvearrowright \\
\curvearrowright\end{array}$ & 3 & $\infty$ & 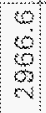 & $\begin{array}{l}0 \\
\frac{1}{3} \\
m\end{array}$ & $\begin{array}{l}0 \\
5 \\
5 \\
5\end{array}$ & $\frac{\infty}{\infty}$ & is & $\begin{array}{l}0 \\
0 \\
\infty\end{array}$ & 0 & s. & $\begin{array}{l}0 \\
\text { के } \\
\text { م. }\end{array}$ & 8 & $\begin{array}{l}0 \\
\frac{\partial}{m} \\
\text { के }\end{array}$ & 8 & $\frac{\square}{\infty}$ & $\begin{array}{l}0 \\
3 \\
\vdots\end{array}$ & $\begin{array}{l}\infty \\
3 \\
\infty\end{array}$ & 3 & a \\
\hline Ajroyy Sample Wh $\{0\}$ & 8 & $\begin{array}{c}\omega \\
\% \\
\omega\end{array}$ & $\infty$ & 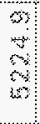 & $\begin{array}{l}+ \\
\infty \\
\infty \\
\infty \\
\infty\end{array}$ & $\frac{\infty}{\infty}$ & 8 & $\begin{array}{l}\infty \\
\infty \\
\infty\end{array}$ & $\begin{array}{l}\xi \\
\omega \\
\omega \\
\vdots\end{array}$ & $\frac{6}{4}$ & 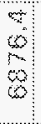 & 8 & 8 & $\begin{array}{c}m \\
\infty \\
\infty\end{array}$ & $\begin{array}{l}\infty \\
\infty \\
m\end{array}$ & 8 & $\begin{array}{l}m \\
m \\
m\end{array}$ & $\frac{9}{8}$ & 9 & 8 & $\begin{array}{l}\infty \\
\$ \\
\$\end{array}$ & $\begin{array}{l}\infty \\
\infty\end{array}$ & $\begin{array}{l}9 \\
a \\
8 \\
3\end{array}$ \\
\hline Texture Modiher - Feald & $\stackrel{2}{=}$ & 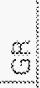 & 8 & 8 & $\vec{s}$ & 8 & $\geqslant$ & 8 & 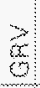 & 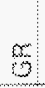 & 8 & $\infty$ & 8 & $\mathrm{E}$ & 8 & 3 & & 2 & 6 & $\vec{a}$ & $\frac{x}{b}$ & & 9 \\
\hline Soll Texure-Fien & -3 & $\omega$ & 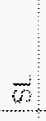 & $\stackrel{20}{3}$ & $\infty$ & 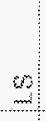 & $\infty$ & $\frac{\infty}{6}$ & 0 & 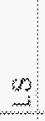 & 9 & $\infty$ & 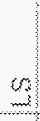 & $\infty$ & $\infty$ & $\infty$ & 8 & 8 & $\infty$ & $\overrightarrow{b i}$ & $\omega$ & 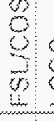 & 9 \\
\hline Soll Texune - Lab & 3 & $\underline{m}$ & $\infty$ & $\omega$ & $\frac{3}{6}$ & $\Delta$ & $\frac{b}{n}$ & $\infty$ & si & $\infty$ & 6 & $\theta$ & $\Delta$ & 6 & $\infty$ & 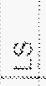 & $\infty$ & $\infty$ & 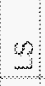 & 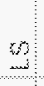 & $\frac{1}{6}$ & $\infty$ & 3 \\
\hline Geomornhis Suface & 6 & 6 & 8 & $\frac{5}{6}$ & 8 & 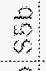 & 8 & 8 & o & 6 & 3 & 8 & 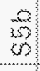 & st & $\infty$ & is & 3 & 8 & 3 & $d$ & 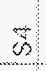 & 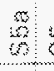 & $\begin{array}{c}0 \\
\vdots \\
0\end{array}$ \\
\hline firkofacies & $\infty$ & 8 & 8 & 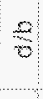 & $\frac{D}{\infty}$ & $\begin{array}{l}5 \\
0 \\
0 \\
0\end{array}$ & 0 & 2 & $\infty$ & $\infty$ & : & 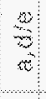 & $\dddot{9}$ & 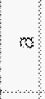 & 9 & $\infty$ & 5 & 8 & 2 & 8 & 8 & $\pi$ & $\infty$ \\
\hline Anostratgraphe Subunt & - & , & : & : & $\infty$ & $\infty$ & $\infty$ & 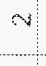 & $\mathrm{E}$ & A & (4) & $\curvearrowright$ & 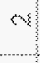 & : & 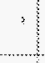 & & ( & : & . & $\mathrm{dit}$ & N & & \\
\hline anostratiggraphic Gnit & $\infty$ & $>$ & $>$ & $x$ & $x$ & $x$ & $\times$ & $x$ & $x$ & $x$ & 2 & 2 & 2 & $>$ & 3 & $>$ & $x$ & 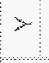 & $>$ & x & $x$ & $x:$ & m \\
\hline Profle & 8 & 8 & 8 & 8 & 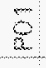 & 8 & 8 & 8 & 8 & 8 & 8 & 8 & 8 & 8 & 8 & $\infty$ & 8 & 8 & 8 & 3 & 8 & 8 & 8 \\
\hline Lombion & 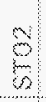 & $\frac{n}{b}$ & $\frac{8}{b}$ & $\frac{\infty}{\infty}$ & $\frac{3}{5}$ & $\frac{2}{6}$ & $\frac{3}{2}$ & $\frac{\infty}{6}$ & 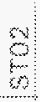 & $\oint_{\infty}^{\infty}$ & 8 & 8 & $\sum_{b}$ & 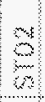 & $\infty$ & $\frac{\beta}{w}$ & $\frac{\infty}{\omega}$ & $\frac{1}{20}$ & $\frac{8}{6}$ & $\frac{\omega}{b}$ & $\frac{\infty}{6}$ & 8 & $\frac{1}{b}$ \\
\hline Lower Weptin $(\mathrm{cm})$ & 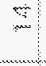 & $\infty$ & 0 & $m$ & $\infty$ & 8 & 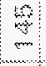 & $\varnothing$ & 8 & $\frac{m}{\infty}$ & 9 & $\infty$ & 2 & 2 & $\mathrm{~s}$ & 9 & 6 & 8 & $\infty$ & 8 & 8 & $=$ & 8 \\
\hline Upper Depth (cra) & 0 & $\square$ & $\Leftrightarrow$ & 8 & $\frac{\cdots}{m}$ & $\infty$ & $\infty$ & 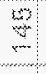 & 9 & 3 & $\frac{m}{\infty}$ & 9 & 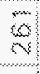 & 0 & 2 & 8 & ? & $\infty$ & 9 & 8 & $\begin{array}{l}m \\
\infty\end{array}$ & 8 & $m$ \\
\hline Gorkon & $\frac{\infty}{8}$ & $\frac{}{3}$ & $\frac{\mathrm{g}}{\mathrm{s}}$ & $\begin{array}{l}3 \\
0\end{array}$ & $\frac{3}{3}$ & $\frac{5}{6}$ & $\frac{a}{2}$ & $\frac{9}{8}$ & $\underset{m}{m}$ & $\frac{3}{6}$ & $\frac{a}{i}$ & $\$$ & $\frac{8}{g}$ & $\frac{x}{x}$ & $\infty$ & $\infty$ & $\mathrm{s}$ & $\frac{5}{6}$ & 8 & $\frac{3}{\alpha}$ & $\frac{3}{8}$ & $\frac{x}{x}$ & $\begin{array}{l}a \\
4 \\
4\end{array}$ \\
\hline Field Sample Coda & $\frac{8}{8}$ & $\begin{array}{l}8 \\
8 \\
b \\
b\end{array}$ & $\frac{8}{8}$ & 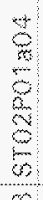 & $\frac{6}{8}$ & $\begin{array}{l}\frac{6}{8} \\
8 \\
8 \\
b\end{array}$ & $\frac{\infty}{\infty}$ & $\begin{array}{l}9 \\
8 \\
8 \\
8 \\
6 \\
6\end{array}$ & $\begin{array}{l}9 \\
8 \\
8 \\
6\end{array}$ & $\frac{5}{8} 8$ & $\frac{\frac{m}{5}}{8}$ & $\begin{array}{l}\frac{\infty}{\infty} \\
\frac{\infty}{\infty} \\
b\end{array}$ & $\begin{array}{l}\frac{p}{5} \\
\frac{2}{b} \\
8 \\
b\end{array}$ & $\frac{8}{8}$ & $\begin{array}{l}\frac{\infty}{\rho} \\
\frac{\rho}{\infty}\end{array}$ & $\frac{8}{8}$ & $\frac{8}{8}$ & $\begin{array}{l}8 \\
8 \\
8 \\
8\end{array}$ & $\begin{array}{l}\frac{\infty}{8} \\
\frac{8}{6} \\
\frac{8}{6}\end{array}$ & $\begin{array}{l}9 \\
\frac{8}{b} \\
\frac{8}{6}\end{array}$ & $\begin{array}{l}\frac{8}{8} \\
8 \\
8 \\
0\end{array}$ & $\frac{8}{8}$ & 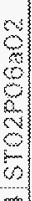 \\
\hline sample & $\omega$ & $m$ & $\infty$ & $\infty$ & 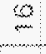 & 2 & 2 & 4 & 8 & $m$ & $m$ & 6 & $m$ & 8 & 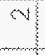 & $\infty$ & 8 & $\stackrel{2}{2}$ & 8 & 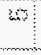 & 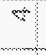 & 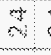 & 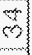 \\
\hline Watch & $\infty$ & 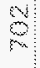 & 8 & बा & 8 & 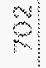 & 8 & 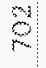 & 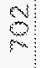 & 8 & 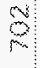 & 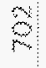 & 8 & 8 & $\rho$ & $\beta$ & $\rho$ & 8 & $\hat{\beta}$ & 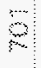 & 2 & 8 & \\
\hline
\end{tabular}




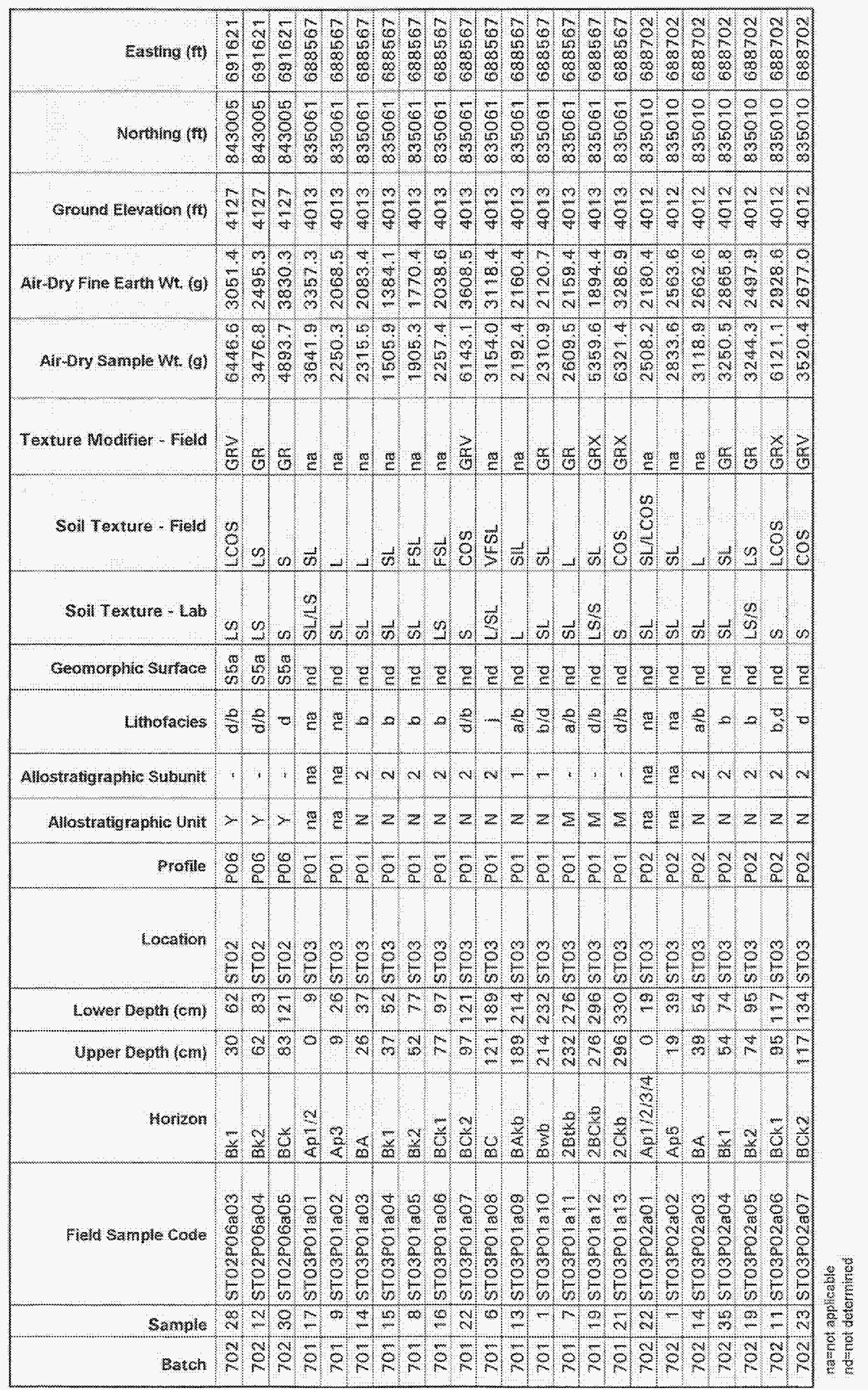




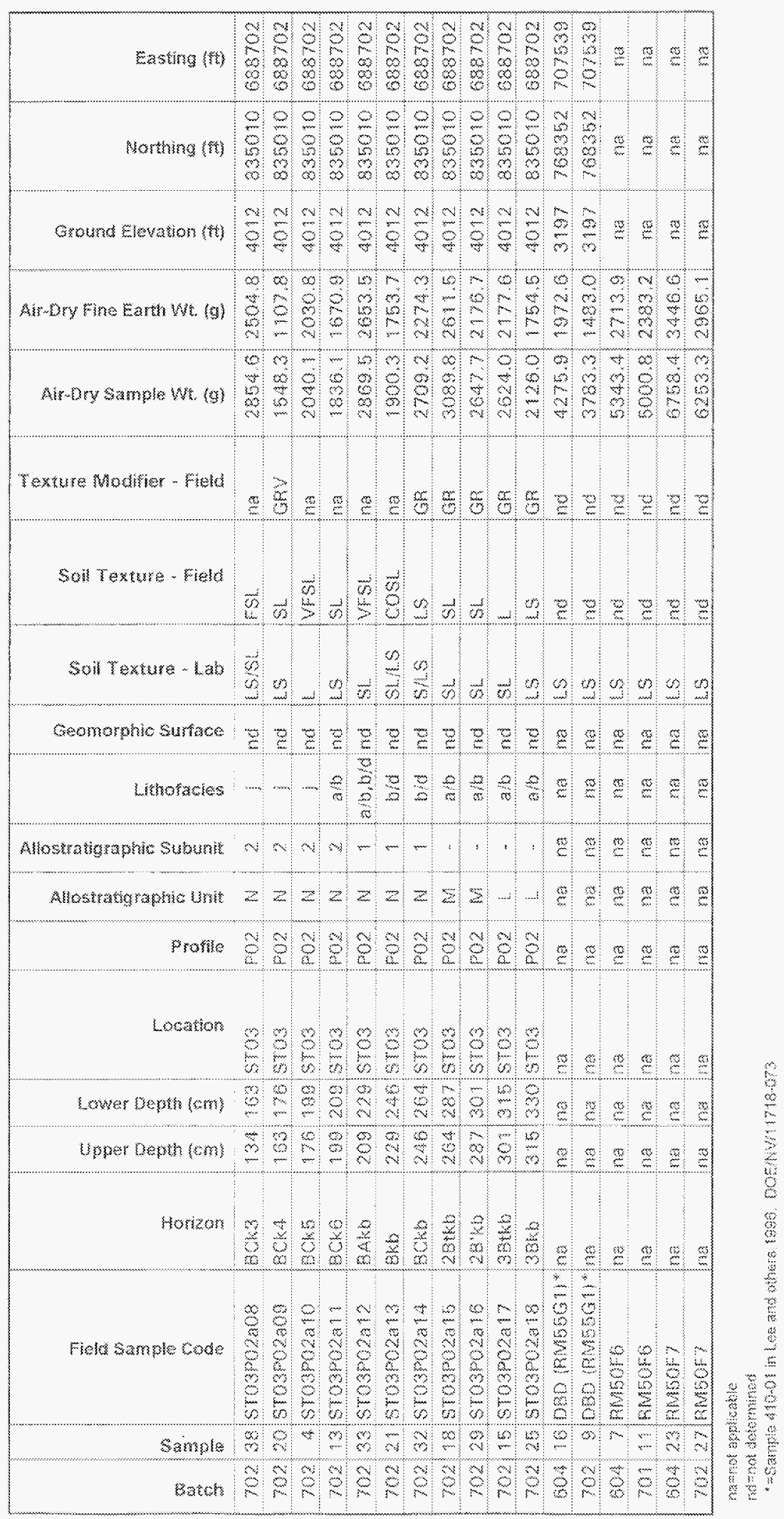




\begin{tabular}{|c|c|c|c|c|c|c|c|c|c|c|c|c|c|c|c|c|c|c|c|c|c|c|c|c|}
\hline & $5 \times$ & 0 & $\mp$ & $\mathrm{m}$ & $\infty$ & 0 & 10 & (1) & $\infty$ & $+m$ & 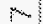 & 10 & $\infty$ & 10 & 5 & का & $\infty$ & 0 & 6 & $\infty$ & 0 & 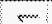 & & \\
\hline Tolat Clay $\{$ wro $\}$ & $\dot{s}$ & $=$ & $\infty$ & $\infty$ & $m$ & $\infty$ & $\omega$ & 6 & एक्ष & $m$ & $\dot{9}$ & भiं & $m$ & sis & $\infty$ & $\hat{\omega}$ & $\hat{\omega}$ & 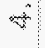 & $m^{n}$ & $\infty$ & $\infty$ & $\infty$ & 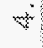 & $\omega$ \\
\hline & $\infty$ & $\mathrm{F}$ & 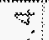 & + & 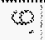 & 0 & $m$ & 0 & $r$ & 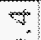 & $\infty$ & $\infty$ & 2 & $\infty$ & 3 & $\infty$ & 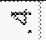 & $\vec{\forall}$ & $\infty$ & $\infty$ & N: & ए. & t: & $1 \%$ \\
\hline Fno sing $\{w 0\}$ & $m$ & 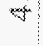 & + & $\square$ & $\leftrightarrow$ & $w$ & it & $B$ & $\infty$ & 8 & $m$ & 100 & $\infty$ & m & + & $\mathrm{B}$ & 60 & $*$ & $\infty$ & + & is & $\infty$ & $\Leftrightarrow$ & 5 \\
\hline & $\infty$ & $r$ & $\infty$ & 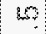 & $r$ & $m$ & 0 & $\infty$ & $\forall$ & $\infty$ & 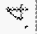 & W & 0 & $m$ & $\gg$ & 4 & $\infty$ & $m:$ & wis & 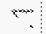 & $m$ & $\%$ & $m$ & $\square$ \\
\hline 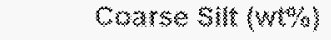 & $\infty$ & $\infty$ & 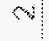 & 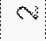 & 政: & $\infty$ & 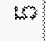 & का & $m$ & \pm & $\varphi$ & 製: & 舟 & of & tis & : & 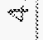 & : & $\infty$ & $m$ & $\infty$ & $\infty$ & $*$ & p) \\
\hline & $t$ & vit & 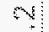 & $\infty$ & 2 & $r$ & $m$ & $\mathrm{~V}$ & - & $\nabla$ & $\otimes$ & $\infty$ : & $\$$ & $\because 1$ & $\Leftrightarrow$ & 2 & $\mathrm{~N}$ & 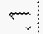 & 81 & $\gg$ & o. & $\infty$ & 39 & 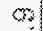 \\
\hline Total silu $\{w \%\}$ & 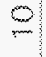 & $m_{m}$ & $\mathrm{~mm}$ & $\infty$ & $\infty$ & $m$ & $\infty$ & 6 & $*$ & $m$ & 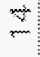 & $\infty$ & 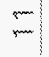 & $\infty$ & $\infty$ & $\infty$ & $\Phi$ & $\infty$ & $\stackrel{50}{7}$ & 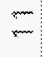 & 2 & $Q$ & $n$ & $\stackrel{\square}{-}$ \\
\hline & $m$ & \& & $\phi$ & 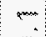 & $\mathbb{N}$ & 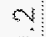 & $m$ & $\infty$ & $\mathrm{N}$ & 38 & $\infty$ & 19 & $\infty$ & 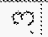 & $\$$ & -1 & 0 & $\$$ & 61 & 8 & (3) & 0 & 0 & 8 \\
\hline Vers the sand $(w r \%)$ & ग & $m$ & $\infty$ & $\infty$ & $\infty$ & 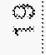 & $\infty$ & 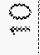 & $\infty$ & $m$ & 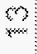 & $=$ & 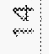 & $\infty$ & 9 & $\infty$ & $\omega$ & $\infty$ & 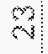 & $\widehat{\mathrm{s}}$ & 4 & $\infty$ & 9 & $\infty$ \\
\hline & $\infty$ & 0 & + & 5 & $\mathrm{~V}$ & $t$ & $m$ & $\infty$ & 4 & 8 & 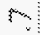 & 0 & $n$ & $\omega$ & 31 & $M$ & $\omega$ & $M$ & of & 0 & $\infty$ & 5 & $\%$ & 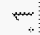 \\
\hline Fine sanc $(w 6)$ & 8 & 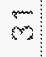 & $m$ & $\infty$ & 8 & w & $\infty$ & 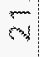 & 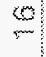 & 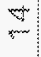 & $m$ & 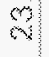 & $\sim$ & 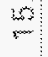 & 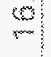 & 8 & $\frac{5}{5}$ & 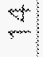 & $m$ & 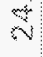 & $\infty$ & $\infty$ & $\infty$ & 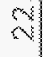 \\
\hline & 8 & $\nabla$ & 4 & 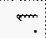 & 3 & 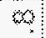 & $\infty$ & 20 & $\infty$ & 9 & $\forall$ & $\infty$ & 0 & 28 & 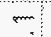 & $\infty$ & $\infty$ & $m$ & $m$ & 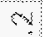 & 0 & 0 & $\infty$ & 0 \\
\hline (kedium Sano $($ Woto $)$ & $\widehat{N}$ & dit & $\vec{m}$ & $\stackrel{\alpha}{*}$ & 5 & $\varnothing$ & $m$ & 8 & 9 & $\infty$ & 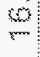 & $\vec{d}$ & $\stackrel{\infty}{\sim}$ & 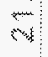 & $\infty$ & of & 0 & $\infty$ & $\stackrel{*}{*}$ & $\infty$ & 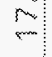 & $\infty$ & $\mathrm{v}$ & $m$ \\
\hline & $\infty$ & m: & 0 & 2 & $\infty$ & $?$ & $m$ & $m$ & $m$ & 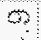 & 2 & 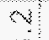 & $m$ & $m$ & 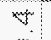 & \%: & $\curvearrowright$ & 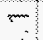 & 12 & 8 & + & 60 & $\infty$ & $\infty$ \\
\hline Caxrse Sand $\{$ wh & $\infty$ & $\infty$ & $\infty$ & $m$ & $\infty$ & $=$ & $\Leftrightarrow$ & $\infty$ & 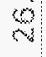 & wit & 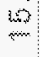 & $\infty$ & $\stackrel{b}{*}$ & $\$$ & 8 & $\vec{b}$ & $\mathrm{~m}$ & 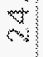 & $\infty$ & $=$ & $\$$ & $\infty$ & $\Leftrightarrow$ & $\infty$ \\
\hline & $r$ & 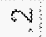 & $\infty$ & 0 & $m=1$ & $m$ & a & 6 & 10 & $m$ & 0 & ?: & $\infty$ & $\infty$ & $m$ & $\infty$ & $\infty$ & $m:$ & $\square$ & 0 & क & $\infty$ & 6 & 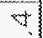 \\
\hline Very Coarse Sand $($ wt\% & wit & $m$ & m & $\infty$ & 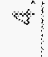 & $\infty$ & $m$ & 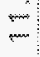 & स+: & $\infty$ & w & + & 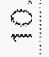 & 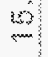 & $\stackrel{03}{-3}$ & $\infty$ & $\stackrel{\infty}{\infty}$ & $\infty$ & 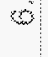 & 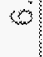 & 6 & $\infty$ & 8 & 0 \\
\hline & 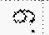 & 9 & 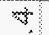 & 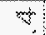 & 5 & 3 & $\infty$ & 3 & $\varnothing$ & $\mathrm{m}$ & 7 & $M:$ & $\nabla$ & 0 & अ & ? & $\varnothing$ & $\diamond$ & 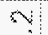 & $m$ & 7 & 0 & 2 & $m$ \\
\hline Total Sand (wro\}) & $\dot{m}$ & 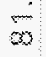 & bl & $\infty$ & $\dot{\phi}$ & $\alpha$ & $\infty$ & $\infty$ & $\dot{m}$ & $\mathrm{ram}^{+1}$ & $\infty$ & $\infty$ & 8 & 8 & $\infty$ & 6 & si & 60 & $\min$ & $\infty$ & 8 & $\infty$ & $\infty$ & $\infty$ \\
\hline & $\mathrm{m}$ & 9 & 0. & 15 & 12 & 15 & 9 & $\because$ & 10 & $?$ & 108 & 0 & 6 & 0 & 3 & $m$ & 0 & $m$ & $\curlyvee$ & $\nabla$ & 7 & 0 & 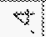 & 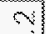 \\
\hline Fne pabules $($ wh & $\infty$ & N & d & s: & si: & $\infty$ & $\infty$ & $\underset{m}{4}$ & $\stackrel{20}{m}$ & एक & di & $\infty$ & 0 & 5 & 6 & w & $\hat{N}$ & $\infty$ & $\infty$ & 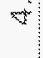 & (5) & is & + & $m$ \\
\hline & +3 & n: & $m$ & $m$ & o: & 42 & 5 & $\infty$ & 6 & 3 & 6 & 9 & 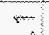 & a. & 80 & 3 & a & 5 & 0 & $\pi$ & 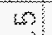 & - & $m$ & 50 \\
\hline Medium Peboles $(\mathrm{w} / \mathrm{l})$ & $m$ & it & i: & $\partial$ & $m$ & $\infty$ & $\infty$ & $=$ & 15 & $\begin{array}{l}\infty \\
x_{2}\end{array}$ & 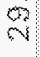 & 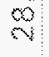 & 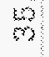 & 9 & $\infty$ & 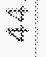 & $\$$ & w & $\widehat{N}$ & $m$ & $m$ & $m$ & $\infty$ & 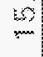 \\
\hline & ৩ & $\infty$ & $m$ & $\infty$ & $x_{0}$ & 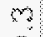 & $\infty$ & $4 ?$ & 0 & (2) & 9 & $\infty$ & $\pi$ & i. & 0 & $\%$ & $\infty$ & 0 & : & œ & $\infty$ & 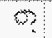 & 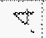 & $?$ \\
\hline Coarse Peblues $(w h)$ & 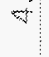 & $m$ & 8 & $m$ & $\infty$ & 0 & 0 & a) & i: & 20 & $\infty$ & 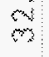 & जै & -1 & $m$ & $\cdots$ & 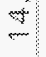 & $\$$ & 客 & 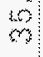 & $\infty$ & 8 & 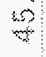 & 0 \\
\hline & is & 0 & ? & a & $0:$ & 2 & $\infty$ & 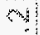 & $m$ & $\infty$ & $=$ & . & $=$ & $\infty$ & 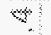 & 9 & ? & 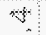 & 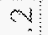 & $=$ & tis & 0 & $m$ & $x-1$ \\
\hline Total Pebules $\{$ who & 8 & 0 & a) & $\infty$ & 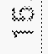 & 6 & $m$ & 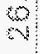 & 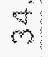 & 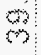 & $\varnothing$ & 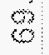 & $\dot{8}$ & 3 & 8 & 6 & $d$ & $i_{m}$ & गे & 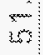 & $m$ & 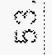 & 6 & 6 \\
\hline kower Deph (cky) & 5 & 5 & 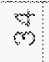 & 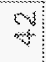 & 8 & 2 & $\infty$ & i & 8 & $r m$ & $\infty$ & 8 & 5 & $\mathrm{v}$ & 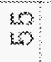 & $r_{*}$ & 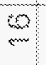 & 9 & $\infty$ & $m$ & 8 & $\infty$ & 8 & $\infty$ \\
\hline \multirow[t]{2}{*}{ Wpoer depth (cm) } & 0 & sot & 6 & $m$ & 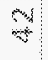 & o & $\infty$ & $\$$ & $\nabla$ & 0 & $r$ & Q & 8 & 0 & + & 8 & $m$ & ras & 0 & $\%$ & $\infty$ & 0 & $\infty$ & 0 \\
\hline & $\frac{1}{\infty}$ & $\infty$ & 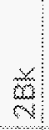 & $\begin{array}{l}2 \\
\frac{2}{\omega t} \\
\text { m }\end{array}$ & $\begin{array}{l}\frac{\partial}{a} \\
\text { d. }\end{array}$ & $\approx$ & $\infty$ & 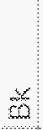 & 3 & $\begin{array}{l}x \\
\frac{1}{2}\end{array}$ & $\begin{array}{c}5 \\
\infty \\
\infty\end{array}$ & $\frac{w}{\infty}$ & $\frac{y}{v}$ & $\frac{U}{b}$ & $\begin{array}{c}\frac{1}{6} \\
\frac{6}{\infty} \\
\infty\end{array}$ & 8 & 3 & $\frac{x}{3}$ & 5 & 3 & $\frac{m}{w}$ & $\frac{x}{x}$ & $\frac{x}{\infty}$ & $\infty$ \\
\hline Fideld Sample cotse & 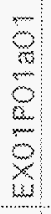 & $\begin{array}{l}\infty \\
\vdots \\
0 \\
0 \\
0 \\
0\end{array}$ & 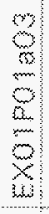 & 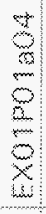 & 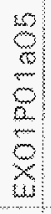 & $\begin{array}{c}0 \\
m \\
0 \\
0 \\
0 \\
6 \\
w\end{array}$ & $\frac{\infty}{\infty}$ & $\begin{array}{l}3 \\
\frac{a}{2} \\
\infty \\
\infty\end{array}$ & 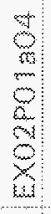 & $\begin{array}{l}3 \\
m \\
0 \\
8 \\
8\end{array}$ & 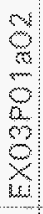 & 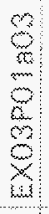 & $\begin{array}{l}8 \\
\frac{8}{8} \\
8 \\
8\end{array}$ & 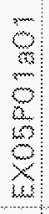 & $\begin{array}{c}\infty \\
\infty \\
\infty \\
\infty \\
\infty \\
\infty \\
\infty\end{array}$ & $\begin{array}{l}\frac{m}{5} \\
\frac{8}{8} \\
\infty \\
8 \\
4\end{array}$ & 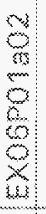 & $\begin{array}{l}\infty \\
8 \\
8 \\
6\end{array}$ & $\begin{array}{l}\frac{1}{8} \\
8 \\
8 \\
8\end{array}$ & $\begin{array}{l}8 \\
8 \\
8 \\
8 \\
8\end{array}$ & $\frac{\infty}{9}$ & $\frac{\sqrt[5]{5}}{\frac{8}{5}}$ & $\frac{2}{8}$ & $\begin{array}{l}m \\
8 \\
8 \\
8\end{array}$ \\
\hline$\$$ mink & 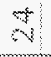 & का & 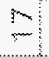 & $\%$ & 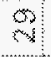 & $\infty$ & 0 & $m$ & $m$ & it & $\stackrel{10}{\infty}$ & $m$ & 2 & 8 & 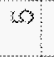 & 2 & $\Phi$ & $\infty$ & $\sim$ & 0 & $\mathrm{~m}$ & 9 & 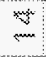 & 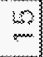 \\
\hline 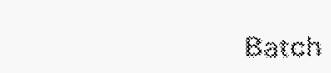 & 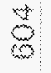 & 8 & 8 & 8 & 8 & 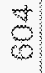 & 8 & 8 & 8 & 8 & 8 & 8 & 8 & 8 & 8 & 8 & 8 & $\dot{0}$ & 8 & 8 & 8 & 8 & 8 & 8 \\
\hline
\end{tabular}




\begin{tabular}{|c|c|c|c|c|}
\hline Total clay (wt\%) & $\infty$ & 20 & $\infty$ & $=$ \\
\hline Fine sill $(w+\%)$ & $\infty$ & $\infty$ & 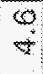 & $\infty$ \\
\hline Coarse Sit (wt\%) & $\phi$ & $\infty$ & $\infty$ & $\infty$ \\
\hline Total sift (wer) & $\frac{\infty}{m}$ & 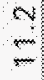 & 8 & 100 \\
\hline Very Fine sand (w\%) & $\mathrm{N}$ & 8 & $\begin{array}{l}\infty \\
\infty\end{array}$ & $m$ \\
\hline Fine sand (wt\%) & $\frac{\pi}{4}$ & $\begin{array}{l}m \\
2\end{array}$ & 2 & $\infty$ \\
\hline Medium sand (wo\%) & $N_{2}^{\infty}$ & $\frac{7}{6}$ & 9 & $\$$ \\
\hline Coarse Sand (wt\%) & 8 & 8 & $\infty$ & $\infty$ \\
\hline Very Coarse Sand (wt\%) & $\infty$ & 5 & $\infty$ & 0 \\
\hline Total Sand (wro) & $\begin{array}{l}0 \\
\infty\end{array}$ & $\begin{array}{l}\infty \\
\infty\end{array}$ & $\begin{array}{l}4 \\
+\end{array}$ & $\infty$ \\
\hline Fine pebbles (wo) & 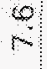 & $\$$ & 8 & $\infty$ \\
\hline Hedium Pebotes (wto) & $\begin{array}{l}9 \\
4\end{array}$ & ${ }^{\infty}$ & 4 & $\begin{array}{l}m \\
0\end{array}$ \\
\hline Coarse pobies (w\%) & $\stackrel{6}{*}$ & $d$ & 9 & $m$ \\
\hline Total Pebules $(w t \%)$ & $\overrightarrow{\mathrm{d}}$ & $\begin{array}{l}20 \\
\mathrm{~N}\end{array}$ & 10 & $\begin{array}{l}\infty \\
N\end{array}$ \\
\hline Lower Deptn (cm) & $\mathrm{b}$ & 2 & $\$$ & 8 \\
\hline Upper Deph (cm) & $\infty$ & 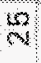 & 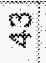 & $\infty$ \\
\hline Horizon & $\frac{2}{8}$ & $\frac{m}{6}$ & 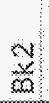 & 8 \\
\hline Field Sample code & $\begin{array}{l}8 \\
8 \\
8 \\
8 \\
8\end{array}$ & $\begin{array}{l}\frac{8}{8} \\
\frac{8}{6} \\
8 \\
8\end{array}$ & $\begin{array}{l}8 \\
8 \\
8 \\
8 \\
8\end{array}$ & $\begin{array}{l}\mathrm{x} \\
5 \\
8 \\
8 \\
8\end{array}$ \\
\hline Sample & $\infty$ & $\begin{array}{l}\infty \\
\diamond\end{array}$ & $\curvearrowright$ & $r$ \\
\hline Earch & 8 & 8 & 8 & 8 \\
\hline
\end{tabular}




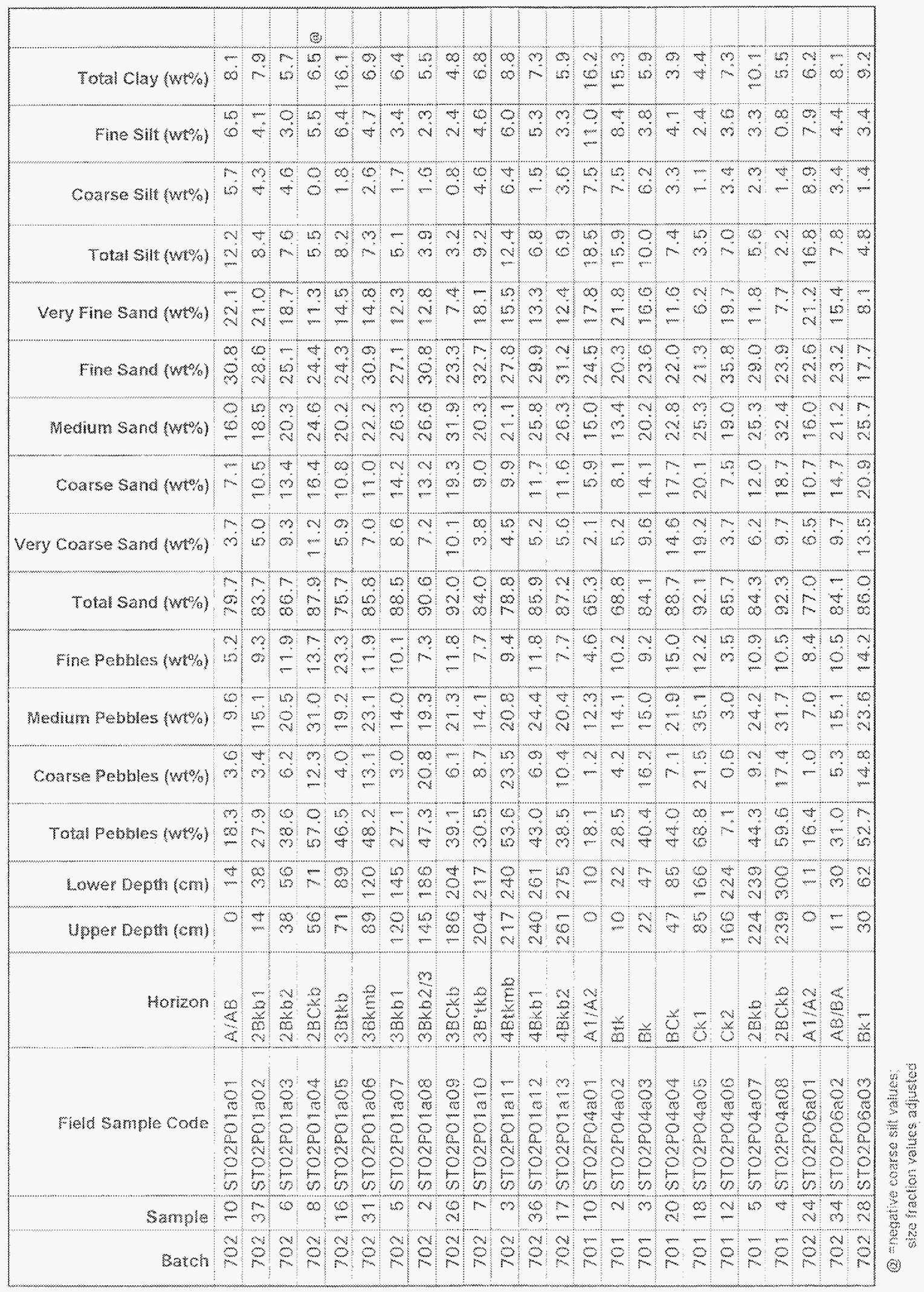




\begin{tabular}{|c|c|c|c|c|c|c|c|c|c|c|c|c|c|c|c|c|c|c|c|c|c|c|c|c|c|}
\hline & 0 & 4 & $\infty$ & 10 & & & & & & & & & & & $\Theta$ & & & & & & & & & & \\
\hline Total Clay $(w \%)$ & $m$ & + & 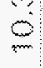 & $\infty$ & 6 & $Q$ & $\infty$ & $\infty$ & $\stackrel{\infty}{\infty}$ & की & 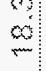 & $\stackrel{\infty}{\infty}$ & $\tilde{v}$ & 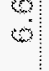 & il & 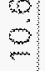 & $\frac{2}{2}$ & $m$ & $\stackrel{0}{*}$ & 0 & mil & 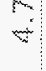 & $\infty$ & $\frac{m}{m a}$ & \\
\hline Fina sitt $(w+s)$ & 8 & $\infty$ & $\infty$ & $\begin{array}{l}\text { D. } \\
\frac{m}{m}\end{array}$ & $\begin{array}{l}\infty \\
0\end{array}$ & $\infty$ & $\infty$ & o & 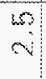 & की & $\begin{array}{l}6 \\
8\end{array}$ & 40 & \: & $\bar{m}$ & $\stackrel{5}{-}$ & 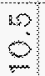 & 9 & 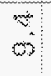 & $\infty$ & $m$ & 9 & $Q$ & 8 & $(\infty)$ & \\
\hline Corarse sir whol & $\infty$ & $\frac{d}{4}$ & $\infty$ & 3 & $\begin{array}{l}01 \\
\infty\end{array}$ & $\vec{b}$ & $\infty$ & 4 & m: & al & $\frac{1}{3}$ & as & $\infty$ & 2 & 9 & $\begin{array}{l}\infty \\
\infty\end{array}$ & م. & 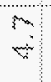 & 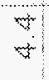 & 8 & 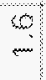 & $\omega$ & $\dot{m}$ & 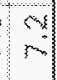 & \\
\hline & 0 & 0 & 3 & 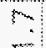 & 8 & m & 2 & $\infty$ & $\infty$ & $?$ & 9 & 0 & 5 & 0 & 2 & $m$ & 8 & $=$ & i: & 3 & 2 & tis & 2 & $\infty$ & \\
\hline Total SAl $(w \%)$ & & & 2 & - & & $m$ & 2 & & & sis & य) & 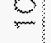 & $m^{m}$ & & & & 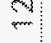 & 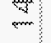 & 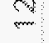 & & & & $m$ & $\frac{\infty}{-1}$ & \\
\hline & $m$ & w & 2 & 20 & $\triangle$ & $x$ & $\mathrm{~N}$ & ल) & $\infty$ & 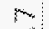 & का & $\Leftrightarrow$ & $\infty$ & -1 & $\mathrm{~N}$ & $\infty$ & $m$ & $m$ & $\infty$ & $m$ & $\infty$ & $=1$ & $\infty$ & + & \\
\hline Very Fine Sand $($ w\% $)$ & $=$ & $\infty$ & $v$ & $\frac{\infty}{m}$ & 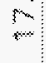 & $p$ & 2 & 5 & $m$ & 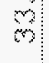 & $m$ & $\infty$ & $\phi$ & $\mathrm{vil}$ & $\infty$ & $m$ & $\vec{v}$ & $\infty$ & $\stackrel{\omega}{m}$ & 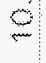 & + & $\infty$ & $\widehat{d}$ & 8 & \\
\hline & 8 & - & $\infty$ & $n$ & 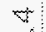 & $\Delta$ & 10 & $\infty$ & $\infty$ & 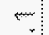 & $m$ & $\infty$ & $\%$ & 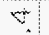 & $\infty$ & $?$ & 0 & $m$ & (4) & $\pi$ & 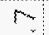 & $\mathrm{M}$ & mo & - & \\
\hline Fine sand $\{w \%)$ & $\infty$ & $\sim$ & 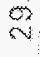 & $\infty$ & $\infty$ & $m$ & 0 & $m$ & $=$ & $m_{m}$ & $m$ & $\infty$ & $\infty$ & $\infty$ & $=$ & 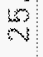 & 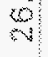 & $=$ & 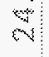 & $m$ & 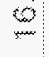 & 2 & $\infty$ & $\infty$ & \\
\hline & 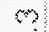 & 0 & 0 & $N$ & $m$ & $\infty$ & $\infty$ & $\infty$ & $m$ & $0 \%$ & 20 & $\infty$ & $m$ & $\infty$ & ए) & $\infty$ & $\infty$ & m & m: & $\infty$ & $\infty$ & - & 0 & 6 & \\
\hline Nedinta Sard (wo\%) & $\Leftrightarrow$ & $\infty$ & $m$ & $v_{m}$ & $\frac{x}{4}$ & $\stackrel{\operatorname{Ln}}{m}$ & $\stackrel{6}{m}$ & $\theta^{2}$ & $\vec{v}$ & al & wi & $\omega$ & $m$ & $\hat{N}$ & $\stackrel{m}{m}$ & $\stackrel{m}{m}$ & 0 & ts & $\dot{Q}$ & $\stackrel{+}{4}$ & $\sqrt{\infty}$ & $\infty$ & $p_{m}$ & $\begin{array}{c}\infty \\
m\end{array}$ & \\
\hline & o & $\infty$ & $m$ & 2 & $\infty$ & $m$ & 0 & $\%$ & $r=$ & $m$ & $\infty$ & $\infty$ & $\infty$ & $m$ & $\curvearrowright$ & 0 & 0 & $m_{3}$ & 2 & 10 & $m$ & 10 & In & $\infty$ & \\
\hline Coarse Sand (wr\%) & $m$ & co & $m$ & $\infty$ & $m$ & $\infty$ & $\infty$ & $\infty$ & $\infty$ & $i$ & Ni & $\infty \hat{s}$ & $\infty$ & 4 & $\infty$ & i. & $\dot{\theta}$ & i: & $\stackrel{\vec{w}}{*}$ & $\dot{0}$ & $\dot{\infty}$ & 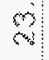 & $\infty$ & $\infty$ & \\
\hline & 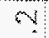 & $\infty$ & $\because$ & 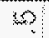 & $\vec{x}$ & $\because$ & $?$ & $?$ & $w$ & 6 & $m$ & $\infty$ & $m$ & का & ) & 3 & $\infty$ & 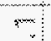 & $\because$ & 6 & 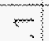 & 6 & $\infty$ & $\infty$ & \\
\hline Very coarse sand $(w 6 \%)$ & $\infty$ & $\stackrel{m}{m}$ & $\omega$ & $\infty$ & क) & w) & म पू & का & $\infty$ & 0 & in & 253 & $m$ & 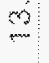 & $\vec{s}$ & o. & $\dot{\nabla}$ & 6 & $\infty$ & 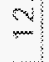 & $\stackrel{m}{m}$ & $\infty$ & $w$ & $m$ & \\
\hline & 0 & $\infty$ & 0 & $\infty$ & $m$ & 9 & 2 & 6 & $?$ & 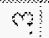 & 5 & 9 & $?$ & 阝 & $\Rightarrow$ & $\pi$ & $\infty$ & $\infty$ & $m$ & $-m$ & a & $\infty$ & 0 & $2 \pi$ & \\
\hline Toral sand $($ wo & $\infty$ & 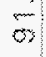 & $\infty$ & $\infty$ & $\dot{B}$ & $\infty$ & $m$ & $\infty$ & $\infty$ & ind & $\infty$ & $\infty$ & 0 & $\infty$ & $\$$ & $\mathrm{mi}_{1}$ & $\infty$ & $\infty$ & $\infty$ & $\infty$ & 8 & $\infty$ & 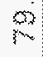 & $\infty$ & \\
\hline & $\infty$ & - & ? & 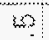 & 0 & $=$ & ? & $2 m$ & -1 & 0 & क? & 2 & 8 & 3 & s! & 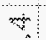 & 3 & $m$ & : & 0 & 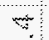 & 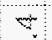 & $\infty$ & $\infty$ & \\
\hline Fine Peboles (wto) & $\infty$ & $\stackrel{N}{-}$ & 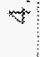 & $\infty$ & $M$ & $\omega$ & $\forall$ & $\omega$ & $\stackrel{t o}{=}$ & - & + & + & $\infty$ & $\infty$ & $\infty$ & wit & $\infty$ & 01 & $m$ & $\infty$ & 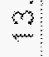 & $\frac{N}{N}$ & 5 & $\infty$ & \\
\hline & $\omega$ & 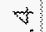 & $\infty$ & 60 & $\infty$ & 0 & 01 & $\infty$ & 0 & d & 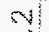 & $\infty$ & $\infty$ & $\Leftrightarrow$ & mi & 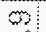 & $\infty$ & $\varnothing$ & $\mathrm{mal}$ & $x^{m}$ & 8 & $N$ & 0 & $\infty$ & \\
\hline 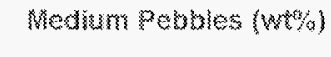 & $\frac{m}{x}$ & $\infty$ & $\infty$ & ए। & $\infty$ & 0 & $\infty$ & 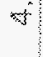 & 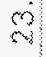 & $\dot{0}$ & $\dot{0}$ & $m$ & $\infty$ & $\dot{m}$ & $\dot{s}$ & $=$ & $\Leftrightarrow$ & wit & 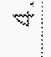 & 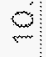 & $\dot{m}$ & $=$ & $\nLeftarrow$ & $\begin{array}{r}m \\
m\end{array}$ & \\
\hline & 0 & 3 & 6 & $\varnothing$ & 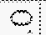 & $\varnothing$ & $\infty$ & $\infty$ & $\infty$ & 8 & 0 & $\infty$ & 68 & $\Leftrightarrow$ & mo: & $\infty$ & 0 & $\infty$ & 0 & ळ & 唯 & का & 7 & 10 & \\
\hline Coarse sebules (wo) & $\infty$ & 0 & 0 & 0 & $\infty$ & 0 & 0 & 0 & N! & 0 & 0 & 0 & 0 & $\mathrm{~m}$ & 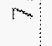 & $m$ & 0 & i & 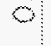 & $\sigma$ & $\infty$ & 0 & 0 & 0 & \\
\hline & $\checkmark$ & $m$ & $\infty$ & -1 & 0 & $\cdots$ & $m$ & $m$ & s & $=$ & $\omega$ & i & $N$ & 0 & O & $m$ & 23 & $\infty$ & $\infty$ & $Q$ & $\alpha$ & 8 & $?$ & . & \\
\hline Total Pebbles (worth) & $\infty$ & $\stackrel{4}{*}$ & $m$ & $\infty$ & $\infty$ & $\infty$ & $\mathrm{Fin}$ & $\dot{2}$ & $\ddot{*}$ & 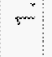 & + & $\infty$ & $\mathrm{sm}$ & $\hat{0}$ & \% & ल & $\infty$ & (I) & $m_{m i}^{\prime}$ & $\vec{x}$ & 0 & s. & $N$ & $\begin{array}{c}\infty \\
\infty\end{array}$ & \\
\hline Lower Deph lcm & $\infty$ & $\bar{\curvearrowright}$ & 0 & $\stackrel{\infty}{\infty}$ & $\infty$ & is & $m_{m}$ & 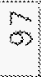 & $\stackrel{m}{m}$ & $\infty$ & $\frac{m}{v}$ & ले & $\infty$ & 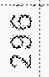 & $\mathrm{m}_{\mathrm{m}}$ & m & 2 & t) & 2 & \$) & $b_{m}^{5}$ & 3 & 8 & $\begin{array}{l}\infty \\
y^{2}\end{array}$ & \\
\hline \multirow[t]{2}{*}{ Upper opph (cm) } & $\mathrm{N}$ & $\$$ & 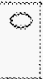 & $\infty$ & ब, & $m$ & 4 & $m_{\infty}$ & 5 & 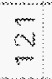 & $\infty$ & $\frac{\pi}{1}$ & $\begin{array}{l}\infty \\
y_{2} \\
\infty\end{array}$ & $\infty$ & $\phi$ & $\infty$ & $Q_{2}$ & $\Leftrightarrow$ & 5 & 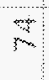 & 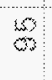 & $m_{m}^{m}$ & 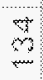 & 8 & \\
\hline & $\frac{m}{6}$ & $\ddot{b}$ & $\frac{4}{2}$ & $\frac{2}{<}$ & $\alpha$ & $\frac{25}{60}$ & $\frac{y}{\infty}$ & $\frac{x}{6}$ & $\frac{1}{6}$ & $\infty$ & के & $\stackrel{\infty}{\infty}$ & $\begin{array}{c}\frac{2}{\alpha x} \\
\hat{\alpha} \\
v\end{array}$ & $\begin{array}{l}0 \\
0 \\
v\end{array}$ & $\begin{array}{c}2 \\
3 \\
3\end{array}$ & $\begin{array}{l}\frac{8}{3} \\
\vdots \\
0 \\
3 \\
3\end{array}$ & $\stackrel{1}{\infty}$ & $\alpha$ & $\frac{\bar{x}}{3}$ & $\frac{y}{\infty}$ & 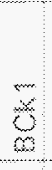 & 4 & $\frac{2}{6}$ & $\frac{7}{6}$ & \\
\hline Fidid Sampie Gode & $\begin{array}{c}8 \\
6 \\
8 \\
6 \\
6\end{array}$ & $\begin{array}{l}3 \\
0 \\
0 \\
0 \\
0\end{array}$ & $\begin{array}{l}0 \\
8 \\
0 \\
0 \\
0\end{array}$ & $\frac{b}{b}$ & 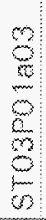 & $\begin{array}{l}\frac{3}{8} \\
\frac{8}{0} \\
\frac{0}{0}\end{array}$ & $\begin{array}{l}3 \\
0 \\
0 \\
0 \\
0 \\
0 \\
6\end{array}$ & 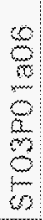 & $\frac{p}{b}$ & 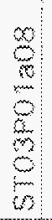 & $\begin{array}{l}3 \\
0 \\
0 \\
0 \\
0 \\
0 \\
0\end{array}$ & 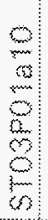 & $\frac{5}{5}$ & $\begin{array}{l}0 \\
0 \\
b \\
b \\
b\end{array}$ & $\begin{array}{l}2 \\
\frac{b}{3} \\
2 \\
b \\
b\end{array}$ & $\frac{b}{b}$ & $\begin{array}{l}b \\
0 \\
0 \\
b \\
b\end{array}$ & $\begin{array}{l}3 \\
\frac{8}{8} \\
\frac{8}{0}\end{array}$ & $\frac{\infty}{\infty}$ & $\begin{array}{l}8 \\
8 \\
8 \\
0 \\
0\end{array}$ & $\begin{array}{l}8 \\
8 \\
8 \\
8 \\
0\end{array}$ & $\frac{\infty}{\infty}$ & $\begin{array}{l}0 \\
0 \\
0 \\
0 \\
0 \\
0\end{array}$ & $\begin{array}{c}\infty \\
\infty \\
6 \\
6 \\
\infty\end{array}$ & 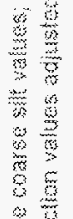 \\
\hline Sample & 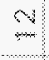 & $\infty$ & $\mathrm{m}$ & $\curvearrowright$ & $\nabla$ & 5 & $\infty$ & $\underset{m}{\infty}$ & $\infty$ & $\infty$ & 3 & 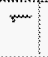 & $m$ & 0 & 5 & $\mathbb{v}$ & 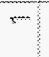 & 焉 & $n$ & $a$ & 5 & 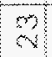 & 6 & 0 & 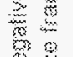 \\
\hline math & 8 & 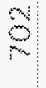 & $\stackrel{m}{m}$ & $p$ & 8 & $\bar{b}$ & $\bar{Q}$ & 0 & 8 & 8 & $\stackrel{m}{2}$ & $m$ & $m_{1}$ & 8 & 8 & 8 & 8 & 8 & 8 & 8 & $\$$ & 8 & 8 & 0 & 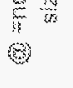 \\
\hline
\end{tabular}




\begin{tabular}{|c|c|c|c|c|c|c|c|c|c|c|c|c|c|c|c|}
\hline Total Clay $(w) / s)$ & $\infty$ & 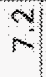 & 9 & $\infty$ & $\infty$ & 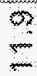 & 3 & 5 & $\stackrel{8}{\circ}$ & 8 & $\infty$ & 8 & $\hat{0}$ & $\stackrel{\infty}{\infty}$ & 80 \\
\hline Fine sitt $(w \%)$ & $\rho^{2}$ & $\infty$ & $\begin{array}{l}0 \\
\mathbb{v}\end{array}$ & 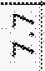 & 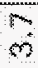 & $\begin{array}{l}7 \\
15\end{array}$ & $\begin{array}{l}\infty \\
m\end{array}$ & 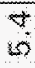 & 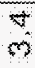 & $m$ & $\infty$ & 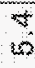 & 8 & 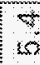 & का \\
\hline Coarse Sil (wt\%) & 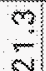 & 6 & $\begin{array}{l}\phi \\
1\end{array}$ & 0 & 5 & 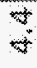 & 0 & 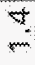 & $=$ & $m$ & $\begin{array}{ll}40 \\
\text { in }\end{array}$ & 0 & 3 & 3 & 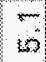 \\
\hline Total silf (wto) & 9 & 9 & $\mathrm{~m}$ & 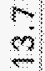 & $\infty$ & $\infty$ & 10 & $\begin{array}{l}\infty \\
+\end{array}$ & 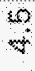 & $\stackrel{0}{0}$ & 9 & 8 & 8 & 8 & 8 \\
\hline Vary fone sand $(w \%)$ & 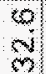 & 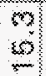 & $<$ & $m$ & $\stackrel{0}{0}$ & 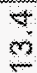 & 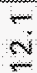 & 0 & 0 & 8 & 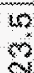 & 9 & 9 & 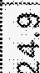 & $\frac{-}{5}$ \\
\hline fine sand (w\%) & $\frac{\pi}{3}$ & $\infty$ & $\infty$ & $\begin{array}{c}7 \\
\infty \\
\end{array}$ & $\infty$ & $\mathrm{t}$ & 0 & 8 & $\stackrel{8}{\Delta}$ & $\mathrm{d}$ & 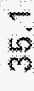 & 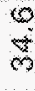 & $\frac{0}{m}$ & $\frac{2}{m}$ & $\infty$ \\
\hline Wedum Sand (wt\%) & $\sqrt{8}$ & $\frac{0}{2}$ & 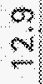 & $\frac{m}{4}$ & $\stackrel{\infty}{\infty}$ & 8 & $\frac{m}{\infty}$ & $\varrho_{0}^{\infty}$ & r & o & 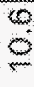 & 8 & 8 & $\infty$ & $\stackrel{9}{2}$ \\
\hline Coarse sand (wt\%) & 8 & $\frac{1}{2}$ & $\begin{array}{l}6 \\
0\end{array}$ & $\begin{array}{l}0 \\
-4\end{array}$ & $\mathrm{~s}$ & $m$ & $\vec{b}$ & 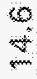 & 6 & 3 & 0 & 0 & 6 & 6 & $\infty$ \\
\hline Very coarse sand (wto) & 8 & † & 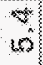 & $\begin{array}{c}0 \\
\infty\end{array}$ & 8 & 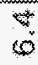 & 5 & $\begin{array}{c}b \\
\infty\end{array}$ & $\begin{array}{l}0 \\
\infty\end{array}$ & $n$ & $\stackrel{4}{2}$ & 8 & $\infty$ & $\infty$ & 9 \\
\hline Total Sand (wo) & $\frac{5}{6}$ & 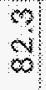 & $\infty$ & 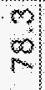 & $\begin{array}{l}\infty \\
\infty \\
\infty\end{array}$ & $\infty$ & $\overrightarrow{0}$ & 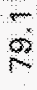 & $\infty$ & $\frac{\infty}{\infty}$ & 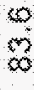 & $\infty$ & 8 & $\infty$ & $\infty$ \\
\hline Fine pebules (wto) & 3 & 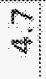 & 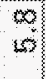 & $\begin{array}{c}0 \\
6\end{array}$ & $\begin{array}{l}0 \\
0\end{array}$ & 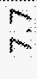 & ? & 8 & 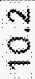 & 0 & 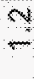 & $m$ & $=$ & $\infty$ & 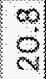 \\
\hline Medium Pebbles (Wro/ & 5 & 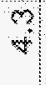 & $\infty$ & $\mathrm{N}$ & $\infty$ & 6 & 0 & $\infty$ & $m$ & 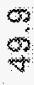 & $\infty$ & $\frac{10}{n}$ & $\infty$ & $\infty$ & $\infty$ \\
\hline Coarse Pebbles (wio) & 8 & 0 & 0 & 0 & 8 & 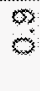 & 0 & 8 & 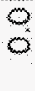 & 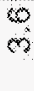 & $\frac{14}{20}$ & 8 & 3 & $\mathrm{~N}$ & 8 \\
\hline Total Pabbles (wt\%) & 0 & 0 & $\infty$ & 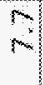 & 6 & $\begin{array}{l}10 \\
10 \\
2\end{array}$ & $\infty$ & 0 & D & $\infty$ & 8 & 8 & 8 & 0 & $\infty$ \\
\hline Loker Deptin (cm) & $\$$ & 8 & $\stackrel{\infty}{N}$ & $\frac{\phi}{3}$ & $\overrightarrow{5}$ & $\infty$ & 8 & $\frac{15}{6 s}$ & 8 & 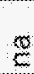 & $\stackrel{g}{E}$ & $\stackrel{g}{\mathscr{g}}$ & 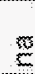 & $\mathrm{g}^{\mathrm{g}}$ & 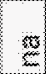 \\
\hline Upost Depth (cm) & 8 & 8 & 8 & 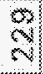 & $\frac{x}{8}$ & $\infty$ & $\infty$ & 8 & $\frac{10}{m}$ & $\sum$ & $\underline{E}$ & $\underline{x}$ & E & 然 & $\mathrm{x}$ \\
\hline Horizon & $\frac{5}{6}$ & $\frac{\infty}{\infty}$ & $\frac{\infty}{\infty}$ & 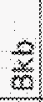 & $\frac{\infty}{\infty}$ & $\frac{o}{\not{z}}$ & $\frac{8}{8}$ & $\frac{9}{s}$ & $\frac{3}{0}$ & $\stackrel{8}{2}$ & 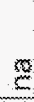 & $\stackrel{E}{E}$ & $\underline{\varepsilon}$ & 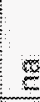 & $=$ \\
\hline Feld Sample code & 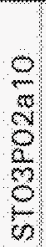 & 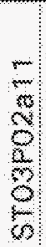 & $\begin{array}{l}\infty \\
8 \\
8 \\
8\end{array}$ & $\begin{array}{l}2 \\
b \\
0 \\
0 \\
0 \\
b\end{array}$ & $\frac{\infty}{8}$ & $\frac{b}{8}$ & $\frac{8}{8}$ & $\frac{1}{8}$ & $\frac{a}{8}$ & 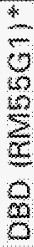 & 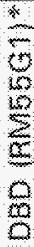 & $\frac{0}{0}$ & $\frac{6}{\frac{6}{2}}$ & $\frac{m}{\infty}$ & $\frac{b}{\frac{6}{6}}$ \\
\hline ample & 子 & 9 & $m$ & $\mathrm{~m}$ & 8 & $\infty$ & 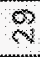 & 28 & 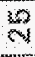 & 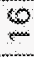 & m & $\pi$ & 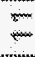 & $\rho$ & $\infty$ \\
\hline Eatoh & 8 & 8 & 8 & 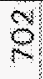 & 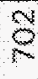 & 8 & 8 & 8 & 8 & 8 & 8 & 8 & 8 & 8 & 8 \\
\hline
\end{tabular}




\begin{tabular}{|c|c|c|c|c|c|c|c|c|c|c|c|c|c|c|c|c|c|c|c|c|c|c|c|c|}
\hline CBD_si (w*\%) & $\frac{10}{8}$ & $\begin{array}{l}0 \\
0\end{array}$ & $\begin{array}{l}10 \\
0 \\
0\end{array}$ & 8 & 8 & $\frac{9}{8}$ & 8 & $\begin{array}{l}0 \\
0 \\
0\end{array}$ & $\frac{3}{8}$ & 8 & 0 & $\begin{array}{l}6 \\
0 \\
0\end{array}$ & 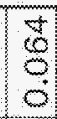 & $\frac{7}{0}$ & $\frac{7}{6}$ & $\frac{9}{5}$ & $\infty_{0}^{+}$ & $\begin{array}{l}3 \\
8 \\
0\end{array}$ & $\begin{array}{l}\infty \\
0 \\
0\end{array}$ & 8 & 8 & 8 & $\begin{array}{l}8 \\
8 \\
0\end{array}$ & $\begin{array}{l}8 \\
8 \\
8\end{array}$ \\
\hline 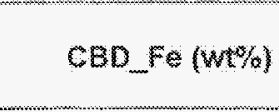 & $\begin{array}{l}b \\
m\end{array}$ & $\begin{array}{c}9 \\
8 \\
0\end{array}$ & $\begin{array}{l}3 \\
m \\
0\end{array}$ & 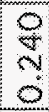 & $\frac{\infty}{N}$ & 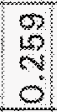 & $\begin{array}{c}\infty \\
\infty\end{array}$ & $\frac{8}{6}$ & $\frac{m}{8}$ & 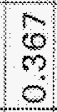 & $\stackrel{8}{8}$ & $\frac{D}{\infty}$ & $\frac{19}{0}$ & $\begin{array}{l}m \\
0\end{array}$ & $\infty$ & $\begin{array}{l}8 \\
8 \\
8\end{array}$ & $\begin{array}{l}\infty \\
0 \\
0 \\
0\end{array}$ & $\begin{array}{l}0 \\
0 \\
0\end{array}$ & 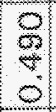 & 8 & $\frac{N}{2}$ & $\begin{array}{l}0 \\
8 \\
0\end{array}$ & & $\frac{2}{5}$ \\
\hline \multicolumn{25}{|l|}{$\mathrm{CaCO}_{3} \mathrm{Eq}_{\mathrm{Flag}}$} \\
\hline Cacos_Eq $(w \%)$ & $\begin{array}{l}\infty \\
\infty\end{array}$ & $\stackrel{\infty}{\infty}$ & $\begin{array}{l}\vec{b} \\
0 \\
\dot{0}\end{array}$ & $\begin{array}{l}\infty \\
10 \\
\infty\end{array}$ & $\frac{5}{10}$ & $\begin{array}{c}5 \\
\dot{0}\end{array}$ & $\begin{array}{l}\infty \\
0 \\
0\end{array}$ & $\mid \begin{array}{l}5 \\
10\end{array}$ & $\begin{array}{l}m \\
0 \\
8\end{array}$ & 8 & $\infty$ & $\frac{5}{m}$ & $\infty$ & $\begin{array}{l}x \\
0 \\
+\end{array}$ & $\infty$ & $\frac{9}{4}$ & $\begin{array}{l}\infty \\
\infty \\
-1\end{array}$ & $\frac{5}{2}$ & 0 & 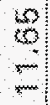 & $\frac{\infty}{m}$ & $\frac{m}{m}$ & $\begin{array}{l}\mathrm{N} \\
\mathrm{N}\end{array}$ & $\frac{\infty}{\infty}$ \\
\hline $\mathrm{pH}$ & $\begin{array}{l} \pm \\
0\end{array}$ & $\begin{array}{l}\infty \\
8 \\
0\end{array}$ & $\frac{a}{a}$ & 8 & $\begin{array}{l} \pm \\
0\end{array}$ & $\begin{array}{l}10 \\
\infty \\
\infty\end{array}$ & $\frac{m}{2}$ & $\begin{array}{l}8 \\
0 \\
0\end{array}$ & $\frac{7}{0}$ & $\begin{array}{l}\infty \\
⿱ \\
0\end{array}$ & $\left.\begin{array}{l}0 \\
0 \\
0\end{array}\right]$ & $\begin{array}{l}8 \\
0 \\
0\end{array}$ & $\begin{array}{l}15 \\
6 \\
0\end{array}$ & $\frac{1}{1}$ & 8 & $\begin{array}{l}5 \\
\infty \\
\infty\end{array}$ & $\frac{2}{6}$ & $\frac{m}{2}$ & $\begin{array}{l}2 \\
\infty\end{array}$ & $\begin{array}{l}6 \\
8 \\
\infty\end{array}$ & $\frac{9}{0}$ & $\begin{array}{l}8 \\
0\end{array}$ & $\frac{1}{6}$ & $\begin{array}{l}9 \\
\infty\end{array}$ \\
\hline Moist (wt\%) & $\begin{array}{l}F \\
=\end{array}$ & 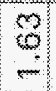 & $\frac{9}{-}$ & 8 & $\begin{array}{l}x_{n} \\
\text { in }\end{array}$ & $\frac{m}{4}$ & $\frac{1}{2}$ & 3 & 5 & 3 & $\bar{v}$ & $\overline{2}$ & S & $\begin{array}{l}5 \\
8 \\
0\end{array}$ & $\bar{N}$ & $\begin{array}{l}8 \\
6\end{array}$ & $\frac{5}{6}$ & $\frac{5}{6}$ & $\begin{array}{l}50 \\
0\end{array}$ & $\frac{5}{4}$ & 5 & $\frac{5}{8}$ & $\bar{d}$ & 8 \\
\hline Lower Depth (cm) & N & $\infty$ & 格 & $\mathrm{N}$ & 8 & $\sigma$ & $\sqrt[10]{20}$ & 8 & 8 & 8 & $\infty$ & 8 & $\infty$ & 8 & 10 & $N$ & $\infty$ & 9 & $\infty$ & 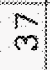 & 8 & $\infty$ & 8 & $\infty$ \\
\hline Upper Depth (cm) & $\varnothing$ & $m$ & $\sqrt{2}$ & $m$ & 8 & o & $\infty$ & 8 & $\$$ & 0 & E & 8 & 8 & 0 & 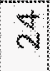 & 0 & $\pi$ & 0 & 0 & 0 & $\infty$ & 6 & $\begin{array}{c}\infty \\
\infty\end{array}$ & 0 \\
\hline nizon & 2 & $\infty$ & $\frac{a x}{\infty}$ & $\frac{\infty}{\infty}$ & $\frac{8}{\frac{8}{2}}$ & 4) & $\infty$ & $\infty$ & $\underset{\infty}{6}$ & $\begin{array}{l}8 \\
\frac{8}{2}\end{array}$ & 芯 & $\frac{x}{\infty}$ & $\underset{\mathrm{c}}{\mathrm{w}}$ & $\frac{\partial}{\omega}$ & $\frac{3}{8}$ & 8 & 3 & 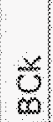 & $<$ & 3 & $\frac{\infty}{\alpha}$ & $\frac{y}{\infty}$ & $\underset{0}{x}$ & $<$ \\
\hline Field Sample code & $\begin{array}{l}8 \\
8 \\
8 \\
8\end{array}$ & $\begin{array}{l}0 \\
0 \\
8 \\
5 \\
x \\
\omega\end{array}$ & 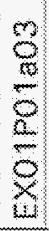 & $\frac{8}{5}$ & $\frac{6}{8}$ & $\begin{array}{c}5 \\
\frac{8}{2} \\
\frac{8}{8} \\
\frac{8}{6}\end{array}$ & $\frac{8}{8}$ & $\begin{array}{l}0 \\
8 \\
8 \\
8 \\
8\end{array}$ & $\begin{array}{l}5 \\
0 \\
0 \\
0 \\
8 \\
0\end{array}$ & $\begin{array}{l}0 \\
0 \\
\frac{0}{8} \\
8 \\
8\end{array}$ & $\begin{array}{l}8 \\
8 \\
0 \\
8 \\
8 \\
8\end{array}$ & $\begin{array}{l}\frac{3}{8} \\
\frac{8}{8} \\
8 \\
8 \\
0\end{array}$ & $\begin{array}{l}8 \\
\frac{8}{8} \\
8 \\
8 \\
8 \\
\end{array}$ & $\frac{5}{9}$ & $\begin{array}{l}\infty \\
0 \\
6 \\
6 \\
6\end{array}$ & $\begin{array}{l}5 \\
5 \\
6 \\
8 \\
8\end{array}$ & $\begin{array}{l}0 \\
\frac{8}{0} \\
0 \\
0 \\
6\end{array}$ & $\begin{array}{l}8 \\
8 \\
8 \\
6 \\
\%\end{array}$ & $\begin{array}{l}5 \\
8 \\
8 \\
8 \\
6\end{array}$ & $\frac{8}{8}$ & $\begin{array}{l}2 \\
8 \\
8 \\
8 \\
8\end{array}$ & $\frac{8}{8}$ & $\begin{array}{l}5 \\
8 \\
8 \\
8 \\
\times \\
1\end{array}$ & $\begin{array}{l}5 \\
\frac{6}{5} \\
8 \\
8 \\
8 \\
4\end{array}$ \\
\hline Sample & क्ष & $\mathrm{N}$ & $m$ & $\infty$ & 9 & $\infty$ & 2 & $m$ & $\frac{\pi}{6}$ & wet & $\propto$ & $=$ & 9 & $m$ & $\infty$ & e & ก & $\infty$ & $\pi$ & $\infty$ & m & $\infty$ & -1 & 4 \\
\hline Batch & 8 & 8 & 8 & 8 & 8 & 8 & 8 & 8 & 8 & 8 & 8 & 8 & 8 & 8 & 8 & 8 & 8 & 8 & 8 & 8 & 8 & 8 & 8 & 通 \\
\hline
\end{tabular}




\begin{tabular}{|c|c|c|c|c|}
\hline cBD_si (wt\%) & $\begin{array}{l}m \\
6 \\
0\end{array}$ & $\begin{array}{l}0 \\
6 \\
0\end{array}$ & $\begin{array}{l}9 \\
5 \\
0\end{array}$ & $\begin{array}{l}8 \\
8 \\
0\end{array}$ \\
\hline CBD_Fe $(\mathrm{W} \%)$ & $\overrightarrow{\mathrm{c}}$ & $\begin{array}{l}\infty \\
\frac{0}{0} \\
0\end{array}$ & $\begin{array}{l}\sqrt{2} \\
0\end{array}$ & $\begin{array}{c}\infty \\
0 \\
0\end{array}$ \\
\hline CaCo3_Eq Flag & & & & \\
\hline $\mathrm{CaCO}^{3} \mathrm{Eq}(w \%)$ & $\frac{8}{9}$ & $\begin{array}{l}\infty \\
-\end{array}$ & $\begin{array}{l}6 \\
0 \\
-2\end{array} \mid$ & $\begin{array}{l}8 \\
6 \\
-\end{array}$ \\
\hline pH & $\begin{array}{l}N \\
\infty \\
\infty\end{array}$ & $\begin{array}{l}\infty \\
\infty \\
\infty\end{array}$ & $\begin{array}{l}1 \\
0\end{array}$ & $\begin{array}{l}9 \\
\infty\end{array}$ \\
\hline Moist (wt;) & $=$ & $\begin{array}{l}5 \\
0\end{array}$ & $\begin{array}{l}\infty \\
0\end{array}$ & $=$ \\
\hline Lower Depth $(\mathrm{cm})$ & $\infty$ & 8 & 8 & 8 \\
\hline Upper Depth (cm) & $\infty$ & $\infty$ & $\$$ & 8 \\
\hline Honizon & $\frac{\infty}{\infty}$ & $\frac{\bar{t}}{\omega}$ & $\frac{\square}{\infty}$ & $\begin{array}{l}7 \\
8 \\
\infty\end{array}$ \\
\hline Feld Sample code & $\begin{array}{l}8 \\
0 \\
8 \\
8\end{array}$ & $\begin{array}{l}8 \\
\frac{8}{6} \\
6 \\
8 \\
8\end{array}$ & $\left|\begin{array}{l}5 \\
0 \\
0 \\
0 \\
0 \\
8 \\
6\end{array}\right|$ & $\begin{array}{l}0 \\
8 \\
8 \\
8 \\
8 \\
0\end{array}$ \\
\hline Sample & $\infty$ & $\infty$ & $\mathbb{x}$ & - \\
\hline Batch & 8 & 8 & 8 & 8 \\
\hline
\end{tabular}




\begin{tabular}{|c|c|c|c|c|c|c|c|c|c|c|c|c|c|c|c|c|c|c|c|c|c|c|c|c|}
\hline CBD_si $(\mathrm{wt} \%)$ & $\begin{array}{l}1 \\
8 \\
0\end{array}$ & $\begin{array}{l}16 \\
8 \\
0\end{array}$ & $\begin{array}{l}\frac{\pi}{3} \\
0 \\
0\end{array}$ & $\begin{array}{c}1 \\
0 \\
0\end{array}$ & $\begin{array}{l}\mathrm{b} \\
0 \\
0\end{array}$ & 8 & 18 & $\begin{array}{l}0 \\
0 \\
0\end{array}$ & 8 & 8 & 18 & 8 & $\begin{array}{l}0 \\
0 \\
0\end{array}$ & 8 & 8 & 8 & $\begin{array}{l}9 \\
8 \\
0\end{array}$ & 8 & 8 & 8 & $\sqrt{0}$ & $\frac{16}{6}$ & & 8 \\
\hline CBD_Fe $(w t \%)$ & 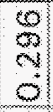 & $\begin{array}{l} \pm \\
5\end{array}$ & $\frac{8}{0}$ & $\infty$ & $\begin{array}{l}4 \\
2 \\
0\end{array}$ & $\frac{9}{6}$ & $\frac{8}{0}$ & $\frac{\infty}{8}$ & $\frac{8}{0}$ & $\begin{array}{l}\infty \\
\delta \\
0\end{array}$ & $\sqrt{\frac{9}{6}}$ & $\frac{10}{5}$ & $\frac{8}{8}$ & 8 & $\begin{array}{l}0 \\
0 \\
0\end{array}$ & 8 & 8 & 8 & $\infty$ & $\sqrt{\infty}$ & & $\begin{array}{l}a \\
0 \\
0\end{array}$ & & $\stackrel{\infty}{0}$ \\
\hline $\mathrm{CaCO}_{\text {_Eq Flag }}$ & & & & & & & & & & & & & & & & & & & & & & & & \\
\hline $\operatorname{Cacos}_{\text {Eq }}(w t \%)$ & $\begin{array}{l}5 \\
0\end{array}$ & $\begin{array}{l}0 \\
0\end{array}$ & $\begin{array}{l}\infty \\
0 \\
\infty\end{array}$ & $\infty$ & $\begin{array}{l}0 \\
\infty\end{array}$ & $\infty$ & $\stackrel{8}{0}$ & $\frac{8}{4}$ & 8 & $\infty$ & $\begin{array}{l}10 \\
10\end{array}$ & $\frac{9}{8}$ & 8 & 9 & $\begin{array}{l}\infty \\
\infty \\
8\end{array}$ & $\infty$ & $\infty$ & 8 & $\begin{array}{l}8 \\
0\end{array}$ & $\sqrt{0}$ & & $\infty$ & & 8 \\
\hline pH & $\begin{array}{c}5 \\
0\end{array}$ & $\begin{array}{l}9 \\
0 \\
\infty\end{array}$ & $\begin{array}{l}\infty \\
01 \\
01\end{array}$ & $\begin{array}{c}0 \\
8 \\
\infty\end{array}$ & $\begin{array}{l}\infty \\
\infty \\
\infty\end{array}$ & 8 & $\frac{15}{\infty}$ & $\begin{array}{l}45 \\
15 \\
\infty\end{array}$ & 今 & $\sigma_{\infty}^{\circ}$ & $\frac{15}{\infty}$ & $\begin{array}{l}\overrightarrow{0} \\
\infty\end{array}$ & $\begin{array}{l}5 \\
b \\
\infty\end{array}$ & $\infty$ & $\begin{array}{c}\infty \\
\infty \\
\infty\end{array}$ & $\frac{0}{2}$ & $\begin{array}{l}8 \\
\infty \\
\infty\end{array}$ & $\frac{9}{\infty}$ & $\begin{array}{l}\infty \\
0 \\
\infty\end{array}$ & 10 & $\infty$ & {$\left[\begin{array}{l}\infty \\
\infty \\
\infty\end{array}\right.$} & & 8 \\
\hline Moist $(w t \%)$ & {$\left[\begin{array}{c}\infty \\
0\end{array} \mid\right.$} & 8 & $\begin{array}{l}\infty \\
0\end{array}$ & 8 & 8 & 0 & 8 & 5 & $\frac{5}{8}$ & 8 & $\underset{m}{q}$ & 8 & $=$ & $\infty$ & $\infty$ & $\infty$ & 0 & 8 & $\infty$ & $\infty$ & 8 & $\infty$ & & 18 \\
\hline Lower Depth $(\mathrm{cm})$ & + & $\infty$ & $\begin{array}{l}0 \\
51\end{array}$ & 5 & 2 & 8 & 8 & $\begin{array}{l}\infty \\
\infty\end{array}$ & 8 & 5 & 孚 & $\infty$ & $\infty$ & 인 & s. & 8 & $\infty$ & $\$$ & 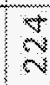 & $\infty$ & 8 & $=$ & & 8 \\
\hline Upper Depth (cm) & o: & \pm & $\infty$ & 6 & 5 & 8 & $\frac{8}{2}$ & $\frac{15}{8}$ & 10 & 18 & $\frac{5}{2}$ & $\stackrel{p}{\alpha}$ & 8 & 0 & 은 & 8 & 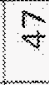 & 6 & $\infty$ & న్ & $\infty$ & 0 & & 9 \\
\hline Honizon & $\begin{array}{l}\alpha \\
\alpha\end{array}$ & $\frac{3}{2}$ & $\frac{\mathrm{d}}{\mathrm{c}}$ & $\begin{array}{l}3 \\
0 \\
N\end{array}$ & $\begin{array}{l}\frac{\partial}{\alpha} \\
\frac{c}{\rho}\end{array}$ & $\frac{\hat{E}}{\mathrm{~m}}$ & $\frac{0}{\infty}$ & $\frac{9}{\frac{9}{m}}$ & {$\left[\begin{array}{l}3 \\
0 \\
0\end{array}\right.$} & $\begin{array}{l}\frac{3}{3} \\
\infty \\
\infty \\
\infty\end{array}$ & $\begin{array}{l}\frac{8}{5} \\
\frac{5}{5} \\
\text { क }\end{array}$ & $\frac{5}{8}$ & $\frac{8}{9}$ & $\frac{8}{5}$ & 象 & $\frac{x}{\infty}$ & 0 & 5 & $\frac{y}{0}$ & & $\varliminf_{0}^{\infty}$ & $\frac{3}{2}$ & & $\frac{5}{\frac{1}{0}}$ \\
\hline Feld Sample Code & $\frac{8}{8}$ & $\begin{array}{l}\frac{\infty}{\infty} \\
\frac{8}{\infty} \\
\frac{\infty}{6}\end{array}$ & $\begin{array}{l}\frac{2}{0} \\
0 \\
\frac{8}{6} \\
\frac{1}{6}\end{array}$ & $\begin{array}{l}8 \\
8 \\
8 \\
8 \\
6\end{array}$ & $\begin{array}{l}\infty \\
5 \\
8 \\
0 \\
0 \\
0\end{array}$ & $\frac{\infty}{8}$ & $\frac{6}{8}$ & $\begin{array}{l}\infty \\
\frac{8}{0} \\
\frac{8}{\infty} \\
\frac{8}{\infty}\end{array}$ & $\frac{8}{8}$ & $\sqrt{\frac{0}{8}} \frac{8}{8}$ & $\frac{5}{8} \frac{5}{5}$ & $\int \frac{2}{\frac{2}{0}}$ & $\frac{\infty}{\infty}$ & $\frac{0}{8}$ & $\frac{b}{b}$ & $\sum_{\infty}^{\infty}$ & $\frac{8}{8}$ & $\frac{6}{8}$ & $\begin{array}{l}\infty \\
0 \\
0 \\
\frac{8}{b}\end{array}$ & $\frac{0}{8}$ & $\frac{\infty}{8}$ & $\begin{array}{l}0 \\
8 \\
8 \\
8 \\
8 \\
0\end{array}$ & $\frac{8}{8}$ & 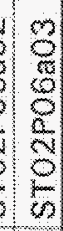 \\
\hline Sample & 9 & $m$ & $\%$ & $\infty$ & 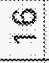 & $\frac{\pi}{9}$ & $\infty$ & s & 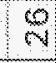 & $m^{m}$ & $m$ & $\stackrel{\infty}{\infty}$ & 5 & 0 & $\infty$ & $m$ & 8 & $\infty$ & $=$ & 6 & $\infty$ & है & 4 & $\infty$ \\
\hline atch & $\propto$ & 8 & 8 & 8 & 8 & 8 & 8 & 8 & 8 & $\stackrel{\mathrm{Q}}{\mathrm{Q}}$ & 8 & 8 & 8 & 8 & 8 & 6 & 8 & 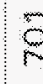 & 8 & 0 & 8 & 8 & 8 & 8 \\
\hline
\end{tabular}




\begin{tabular}{|c|c|c|c|c|c|c|c|c|c|c|c|c|c|c|c|c|c|c|c|c|c|c|c|c|}
\hline CBD_si $(w \%)$ & {$\left[\begin{array}{l}0 \\
6 \\
6\end{array}\right.$} & $\begin{array}{l}4 \\
5 \\
0\end{array}$ & 8 & $\begin{array}{c}8 \\
8 \\
8\end{array}$ & $\frac{1}{6}$ & $\frac{7}{8}$ & 8 & 8 & 8 & 8 & $\begin{array}{c}\infty \\
0 \\
0 \\
0\end{array}$ & 8 & $\begin{array}{c}6 \\
0\end{array}$ & 8 & 8 & 8 & $\frac{18}{8}$ & 5 & $\begin{array}{l}0 \\
0 \\
0\end{array}$ & & 8 & 8 & $\begin{array}{l}2 \\
8 \\
8\end{array}$ & $\begin{array}{l}6 \\
5 \\
0 \\
0\end{array}$ \\
\hline CBD Fe $(w \%)$ & {$\left[\begin{array}{c}\infty \\
0 \\
0\end{array}\right.$} & $\frac{9}{2}$ & $\stackrel{N}{N}$ & $\frac{8}{3}$ & 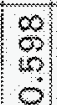 & $\begin{array}{l}0 \\
4 \\
0\end{array}$ & $\begin{array}{l}Q \\
0\end{array}$ & 8 & $\frac{R}{0}$ & $\frac{8}{8}$ & $\begin{array}{l}\infty \\
4 \\
0\end{array}$ & $\mathrm{~g}$ & $\begin{array}{l}6 \\
2 \\
0\end{array}$ & $\frac{5}{6}$ & $\frac{5}{5}$ & $\frac{7}{9}$ & $\frac{6}{2}$ & $\frac{\infty}{2}$ & $m$ & $\underset{v}{N}$ & $\frac{6}{0}$ & $\begin{array}{l}\wp \\
\infty \\
\infty\end{array}$ & $\begin{array}{l}\infty \\
\infty \\
\mho \\
0\end{array}$ & $\begin{array}{c}0 \\
8 \\
8\end{array}$ \\
\hline Cacos Eq Flag & & & & & & & & 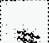 & $x_{0}$ & & & $\Rightarrow$ & & & & & & & & & & & & \\
\hline $\operatorname{CaCo}_{3} \mathrm{Eq}(w \%)$ & $\frac{N}{0}$ & $\begin{array}{l}5 \\
6 \\
0\end{array}$ & $\frac{N}{4}$ & $\begin{array}{l}\infty \\
6 \\
6\end{array}$ & $\begin{array}{l}9 \\
0 \\
N\end{array}$ & $\frac{m}{2}$ & $\begin{array}{c}9 \\
9 \\
-\end{array}$ & 8 & 8 & $\begin{array}{l}6 \\
5 \\
\sim\end{array}$ & $\begin{array}{l}8 \\
0\end{array}$ & 8 & 8 & 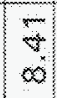 & $\frac{d}{m}$ & w & $\begin{array}{l}5 \\
6\end{array}$ & ले & $\begin{array}{l}\text { wy } \\
\text { s. }\end{array}$ & $\begin{array}{l}8 \\
0\end{array}$ & $\underset{\sim}{q}$ & $\begin{array}{l}9 \\
8 \\
-1\end{array}$ & $\begin{array}{l}\infty \\
0 \\
-10\end{array}$ & $\begin{array}{l}9 \\
9 \\
-1\end{array}$ \\
\hline ph & $\frac{m}{6}$ & $\begin{array}{l}13 \\
7 \\
0\end{array} \mid$ & $\begin{array}{c}5 \\
\infty \\
\infty\end{array}$ & $\begin{array}{l}\infty \\
\infty\end{array}$ & $\frac{10}{0}$ & m & $\left.\begin{array}{l}0 \\
0 \\
0\end{array}\right]$ & के & $\begin{array}{l}5 \\
\infty\end{array}$ & $\begin{array}{c}\infty \\
\infty\end{array}$ & 8 & 8 & $\begin{array}{l}10 \\
\infty \\
m\end{array}$ & $\infty$ & $\frac{1}{\infty}$ & $\begin{array}{c}5 \\
\infty \\
\infty\end{array}$ & $\begin{array}{l}8 \\
\infty\end{array}$ & $\begin{array}{l}5 \\
5 \\
9\end{array}$ & $\frac{\infty}{0}$ & $\begin{array}{l}5 \\
0\end{array}$ & 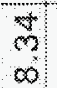 & $\begin{array}{l}0 \\
\$ \\
\infty\end{array}$ & $\begin{array}{l}0 \\
0 \\
\infty\end{array} \mid$ & $\begin{array}{l}2 \\
\infty\end{array}$ \\
\hline Moist $\{w t \%\}$ & $\frac{5}{8}$ & $\begin{array}{l}5 \\
0\end{array}$ & $\frac{x}{4}$ & 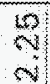 & $\begin{array}{l}10 \\
\mathrm{~d}\end{array}$ & $\infty$ & 8 & 5 & $=$ & â & $\infty$ & $\frac{10}{2}$ & 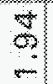 & 9 & 8 & $\approx$ & 8 & $\frac{N}{2}$ & 0 & $\begin{array}{l}8 \\
0\end{array}$ & $\begin{array}{l}\infty \\
0\end{array}$ & $\begin{array}{l}\rho \\
0\end{array}$ & 5 & $\begin{array}{l}5 \\
8\end{array}$ \\
\hline Lower Depth (cm) & $\infty$ & $\sqrt{6}$ & $\infty$ & $\infty$ & $m$ & $\infty$ & $m$ & 8 & 임 & $\infty$ & $\frac{\pi}{6}$ & $\stackrel{8}{8}$ & $\frac{1}{8}$ & a & 8 & $\stackrel{2}{=}$ & $m$ & : & 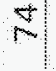 & $\infty$ & $=$ & $\frac{b}{2}$ & 8 & $\begin{array}{c}\infty \\
m\end{array}$ \\
\hline Upper Depth $(\mathrm{cm})$ & 8 & $m$ & 0 & $\infty$ & $\infty$ & 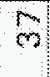 & 8 & n & 5 & $\bar{N}$ & 8 & $\frac{d}{\alpha}$ & $\sqrt{x}$ & $\left(\begin{array}{l}0 \\
n \\
2\end{array}\right.$ & $\begin{array}{l}\infty \\
8\end{array}$ & 0 & 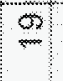 & $m$ & 8 & 5 & 15 & 5 & 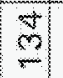 & 8 \\
\hline rizon & 2 & $\underset{\infty}{0}$ & $\frac{1}{8}$ & $\frac{3}{2}$ & 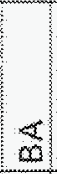 & $\frac{\check{x}}{\infty}$ & $\frac{y}{\infty}$ & $\underset{\infty}{6}$ & $\frac{\mathscr{T}}{0}$ & 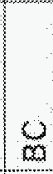 & $\frac{9}{\infty}$ & $\frac{5}{3}$ & $\frac{\infty}{\infty}$ & $\begin{array}{l}0 \\
0 \\
0 \\
0\end{array}$ & $\frac{8}{5}$ & $\frac{5}{8} \frac{8}{8}$ & 8 & $\infty$ & $\frac{7}{\infty}$ & $\frac{\mathbb{x}}{0}$ & $\dot{x}$ & $\underset{0}{0}$ & $\underset{\infty}{\infty}$ & के \\
\hline Field Sample code & $\begin{array}{l}8 \\
8 \\
8 \\
8 \\
6\end{array}$ & $\begin{array}{l}8 \\
8 \\
8 \\
8\end{array}$ & $\begin{array}{c}0 \\
0 \\
0 \\
0 \\
0\end{array}$ & $\frac{\frac{8}{\infty}}{\frac{2}{b}}$ & $\begin{array}{c}8 \\
8 \\
8 \\
6 \\
6\end{array}$ & $\begin{array}{l}\frac{3}{8} \\
\frac{2}{6} \\
\frac{6}{6}\end{array}$ & $\frac{2}{8}$ & $\frac{8}{8}$ & $\frac{8}{8}$ & $\frac{\infty}{5}$ & $\frac{8}{8}$ & $\frac{0}{8}$ & $\frac{5}{6}$ & $\frac{a}{\infty}$ & 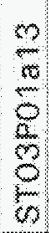 & $\frac{8}{8}$ & $\frac{8}{8}$ & $\frac{8}{8}$ & $\begin{array}{l}5 \\
8 \\
8 \\
8 \\
6\end{array}$ & $\frac{8}{8}$ & $\begin{array}{l}8 \\
8 \\
8 \\
8 \\
6\end{array}$ & $\begin{array}{l}\infty \\
\infty \\
\infty \\
\infty \\
\infty \\
\infty \\
\infty\end{array}$ & $\begin{array}{l}\infty \\
0 \\
8 \\
8 \\
0 \\
0 \\
5\end{array}$ & $\begin{array}{l}0 \\
0 \\
0 \\
0 \\
0 \\
b\end{array}$ \\
\hline Sample & 2 & $\%$ & $m$ & $\infty$ & + & 2 & $\infty$ & 1 & N & 6 & 2 & - & $m$ & 9 & $\bar{n}$ & $\alpha$ & $=$ & 난 & $m$ & 9 & 5 & 2 & $\infty$ & 8 \\
\hline atch & $\mathrm{p}$ & 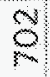 & 8 & 8 & 0 & 5 & 8 & 8 & 15 & $\bar{R}$ & 8 & 5 & 8 & 5 & 8 & 8 & 8 & $\mathcal{Q}$ & 8 & 8 & 8 & 8 & 8 & d \\
\hline
\end{tabular}




\begin{tabular}{|c|c|c|c|c|c|c|c|c|c|c|c|c|c|c|c|c|}
\hline$C B O 51\{w \%\}$ & 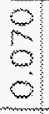 & $\begin{array}{l}m \\
0\end{array}$ & 8 & 3 & $\frac{5}{6}$ & $\$$ & 它 & $\begin{array}{l}5 \\
6 \\
0\end{array}$ & $\begin{array}{l}0 \\
15 \\
0\end{array}$ & $\begin{array}{l}2 \\
0 \\
0\end{array}$ & 8 & 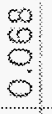 & 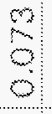 & 8 & $\begin{array}{l}8 \\
0\end{array}$ & \\
\hline $690, F e(4 \%)$ & $\begin{array}{l}\infty \\
8 \\
0\end{array}$ & 4 & 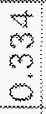 & $\begin{array}{l}\infty \\
\infty\end{array}$ & $\mathrm{v}$ & $\begin{array}{l}\infty \\
\wp\end{array}$ & 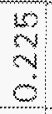 & $\begin{array}{l}9 \\
8\end{array}$ & $\begin{array}{l}\frac{1}{2} \\
3 \\
\vdots\end{array}$ & \begin{tabular}{l}
$m$ \\
\hdashline \\
0
\end{tabular} & $\frac{m}{d}$ & $\begin{array}{l}3 \\
\infty\end{array}$ & $\begin{array}{l}\infty \\
0 \\
0\end{array}$ & $\infty$ & $\begin{array}{l}\infty \\
0\end{array}$ & \\
\hline CaCO3 Eq Fag & & & & & & & & & & & & & & & & \\
\hline $\mathrm{CaCO}_{2} E \mathrm{Eq}(\mathrm{m} \%)$ & $\frac{m}{3}$ & $\infty$ & $m$ & 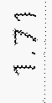 & 9 & $\infty^{\infty}$ & $\begin{array}{l}-m \\
0 \\
5\end{array}$ & $\begin{array}{l}2 \\
\infty\end{array}$ & 0 & $\begin{array}{l}m \\
\mathrm{r}\end{array}$ & 4 & $\begin{array}{l}5 \\
0\end{array}$ & $\begin{array}{l}0 \\
0 \\
0\end{array}$ & 8 & $\infty$ & \\
\hline$m$ & $\infty$ & $\frac{8}{\infty}$ & $\infty$ & $\begin{array}{l}\infty \\
\infty\end{array}$ & $\frac{\infty}{\infty}$ & $\stackrel{m}{\infty}$ & $\begin{array}{l}\infty \\
\infty\end{array}$ & $\begin{array}{c}\overrightarrow{3} \\
\infty\end{array}$ & $\begin{array}{l}m \\
\infty\end{array}$ & $\begin{array}{l}m \\
m\end{array}$ & $\begin{array}{c}9 \\
\infty\end{array}$ & 9 & $\frac{m}{\infty}$ & $\frac{2}{2}$ & 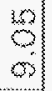 & \\
\hline hoks $\{(w \%)$ & vit & $\frac{m}{m}$ & $\begin{array}{c}d \\
\infty \\
m\end{array}$ & $=$ & 0 & 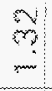 & 0 & 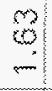 & $\begin{array}{l}\text { } \\
\cdots \\
-\end{array}$ & 4 & $\begin{array}{l}8 \\
0\end{array}$ & $=$ & 5 & $\begin{array}{c}\infty \\
\infty\end{array}$ & $\begin{array}{c}8 \\
0\end{array}$ & \\
\hline Lower bepts (cm) & $\stackrel{\sigma}{m}$ & 8 & $\stackrel{Q}{\Delta}$ & $\stackrel{\infty}{\square}$ & 8 & 8 & 8 & $\frac{6}{6}$ & 0 & $\stackrel{\mathscr{E}}{\Perp}$ & $\underbrace{2}$ & $\stackrel{2}{2}$ & $\stackrel{d}{\varrho}$ & ge & s & \\
\hline \multirow[t]{2}{*}{ Upper Depth (cm) } & 8 & 9 & 9 & $\begin{array}{l}3 \\
\sim\end{array}$ & $\frac{9}{m}$ & 8 & $\frac{m}{d v}$ & 8 & $\frac{b}{2}$ & $\stackrel{0}{=}$ & $\stackrel{\infty}{\Perp}$ & $\underline{w}$ & 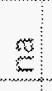 & 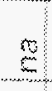 & $\underset{\Xi}{\mathcal{E}}$ & \\
\hline & $\begin{array}{l}1 \\
6 \\
6\end{array}$ & $\frac{9}{6}$ & $\frac{9}{3}$ & $\frac{9}{8}$ & $\begin{array}{l}3 \\
0 \\
0\end{array}$ & $\begin{array}{l}0 \\
\frac{0}{3} \\
\infty \\
\infty\end{array}$ & $\begin{array}{l}\frac{m}{2} \\
\frac{1}{v} \\
\mathrm{w}\end{array}$ & $\begin{array}{c}\infty \\
\frac{2}{\infty} \\
\infty \\
c\end{array}$ & $\frac{3}{\infty}$ & $\mathrm{c}$ & $\frac{\sigma_{0}}{\infty}$ & $\stackrel{m}{\Sigma}$ & $\stackrel{m}{s}$ & $\underline{s}$ & 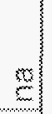 & \\
\hline Fich Sample Code & 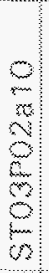 & $\frac{m}{8}$ & 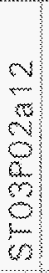 & $\begin{array}{l}\frac{2}{6} \\
\frac{2}{8} \\
\frac{2}{2}\end{array}$ & $\begin{array}{l}\frac{a}{50} \\
\frac{8}{b} \\
\frac{2}{b}\end{array}$ & $\begin{array}{l}m \\
8 \\
8 \\
0 \\
0 \\
0\end{array}$ & $\begin{array}{l}0 \\
0 \\
0 \\
0 \\
0 \\
b\end{array}$ & 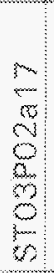 & $\begin{array}{l}\frac{b}{p} \\
p \\
b \\
b \\
b\end{array}$ & $\begin{array}{l}\frac{3}{0} \\
0 \\
40 \\
\frac{2}{0} \\
\frac{c}{6} \\
0 \\
0\end{array}$ & 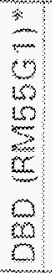 & $\frac{4}{2}$ & $\begin{array}{l}0 \\
0 \\
2 \\
2 \\
2 \\
2\end{array}$ & $\frac{3}{3}$ & $\begin{array}{l}m \\
6 \\
5 \\
5\end{array}$ & $\frac{3}{2}$ \\
\hline sample & 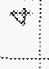 & $m$ & $\infty$ & 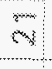 & $m$ & + & 8 & 80 & $\Leftrightarrow$ & 20 & $\infty$ & $m$ & -1 & 3 & 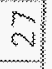 & $=$ \\
\hline arator & $\stackrel{8}{p}$ & 8 & $\omega^{\infty}$ & $\infty$ & $\overrightarrow{8}$ & $p^{3}$ & $\infty$ & $\oint_{m}$ & $\infty$ & 8 & $\infty$ & 8 & 8 & 8 & 0 & \\
\hline
\end{tabular}




\begin{tabular}{|c|c|c|c|c|c|c|c|c|c|c|c|c|c|c|c|c|c|c|c|c|c|c|c|c|}
\hline$P<200$ & $\sqrt{20}$ & 8 & 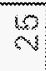 & $\Delta$ & $M$ & $\square$ & 5 & 9 & $\infty$ & $\mathrm{m}$ & 2 & $\infty$ & & $\infty$ & $m$ & $m$ & $Q$ & 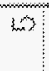 & di & 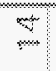 & 8 & is & $\infty$ & त) \\
\hline$P<40$ & $m$ & $m_{n}$ & $\infty_{m}$ & $\infty$ & $\infty$ & 8 & 6 & of & $\infty$ & 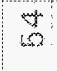 & 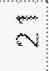 & 8 & $\sqrt{2}$ & $\otimes$ & 2 & $\sqrt{4}$ & 8 & कु & $m$ & $\infty$ & 8 & 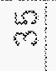 & 긴 & $\mathbb{Q}$ \\
\hline$p<40$ & 8 & 3 & 5 & $\infty$ & $\infty$ & $\infty$ & $\infty$ & $m$ & 8 & 8 & 9 & $\bar{m}$ & 8 & 6 & $\mathrm{~m}$ & 6 & $\infty$ & 8 & $\$$ & 8 & 8 & 8 & का & 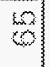 \\
\hline$p<x$ & $\infty$ & 8 & 5 & 19 & 9 & $\infty$ & 10 & $\infty$ & $\infty$ & 6 & $\infty$ & लि & $\infty$ & 6 & 9 & $\infty$ & 8 & $\begin{array}{ll}20 \\
\infty\end{array}$ & 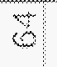 & 9 & 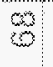 & 8 & 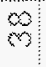 & $\mathrm{m}$ \\
\hline$p<3 / 8-i n$ & 3 & 5 & 9 & 8 & 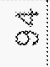 & $\infty$ & 10 & 8 & $\infty$ & $m_{n}^{3}$ & $\dot{m}$ & 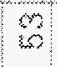 & 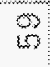 & 8 & 8 & $r^{2}$ & $N$ & 8 & 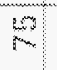 & 8 & 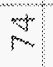 & 8 & t & 8 \\
\hline$p<3|k-m| m$ & 8 & $\$$ & 8 & 8 & 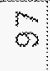 & 8 & 8 & 8 & $B$ & $\infty$ & 8 & $\infty$ & 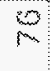 & $\infty$ & $\infty$ & 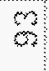 & 19 & $R$ & $\infty$ & 6 & $\infty$ & $\infty$ & 20 & $\begin{array}{l}\infty \\
\infty\end{array}$ \\
\hline$\beta<\{-1\}$ & 8 & 9 & 8 & 8 & $B$ & 8 & 8 & 8 & 8 & $\infty$ & 5 & $\mathrm{~s}$ & $\infty$ & $\phi$ & 5 & 5 & $\infty$ & $\infty$ & $\infty$ & $N$ & $\infty$ & $\infty$ & 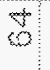 & 9 \\
\hline$p<1 / 2-i n$ & $\infty$ & $\%$ & 8 & 8 & 9 & 8 & 8 & 8 & $g$ & 8 & $\infty$ & $\infty$ & $\infty$ & 8 & 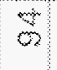 & 8 & 8 & 8 & 8 & $\infty$ & 5 & 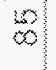 & $m$ & 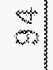 \\
\hline$\beta<2-i m$ & $\$$ & : & 8 & 8 & $a$ & 8 & 8 & 8 & 8 & 10 & $\infty$ & $\frac{m}{\alpha 2}$ & $\infty$ & 8 & 8 & $\$$ & $\begin{array}{l}\infty \\
0\end{array}$ & के & 8 & 8 & 19 & 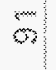 & $\infty$ & 9 \\
\hline$p<3-4 n$ & 8 & 8 & 8 & 8 & 8 & 8 & 8 & 8 & 8 & 8 & 8 & 8 & 8 & 8 & 8 & 8 & 8 & 8 & 8 & 8 & 8 & $\oint$ & 8 & 9 \\
\hline sintrolay_USCS $\left(w^{6} \%\right)$ & 0 & $\mathrm{~m}$ & $\begin{array}{l}\infty \\
0\end{array}$ & 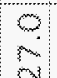 & $m$ & $\omega$ & 8 & $m$ & 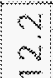 & 8 & $\begin{array}{l}5 \\
9\end{array}$ & $\begin{array}{l}\infty \\
5\end{array}$ & 8 & $\begin{array}{l}0 \\
0\end{array}$ & $\begin{array}{l}4 \\
0\end{array}$ & $\begin{array}{l}\infty \\
\infty\end{array}$ & 9 & $\begin{array}{l}0 \\
\infty\end{array}$ & $\begin{array}{l}5 \\
S\end{array}$ & 9 & $\infty$ & 3 & $m$ & 9 \\
\hline & $\infty$ & $\alpha$ & $m$ & $\infty$ & r & - & $r$ & 0 & $\infty$ & $\infty$ & $\omega$ & b: & 3 & 0 & 0 & 10 & $m$ & $\infty$ & 0 & 0 & $\triangle$ & 0 & 0 & $\infty$ \\
\hline Sand_uscs $(w t \%)$ & 6 & 8 & 8 & 8 & 8 & 0 & 8 & $m$ & 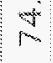 & 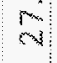 & 3 & 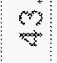 & $\infty$ & 6 & 8 & $\mathrm{~d}$ & 10 & 9 & $m$ & 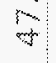 & 8 & 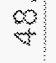 & : & 8 \\
\hline Gravel USCS $\{$ wro & $\begin{array}{l}m \\
6\end{array}$ & $\begin{array}{l}9 \\
0\end{array}$ & $\mathrm{~s}$ & 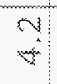 & $\infty$ & 60 & 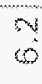 & $\begin{array}{l}\infty \\
\infty\end{array}$ & $\infty$ & $\frac{r}{2}$ & $\infty$ & 8 & 8 & 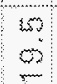 & 2 & $\begin{array}{l}\infty \\
\infty\end{array}$ & 4 & $\infty$ & $\$$ & $\infty$ & $\begin{array}{l}m \\
m \\
m\end{array}$ & $\infty$ & wis & $\begin{array}{l}6 \\
2\end{array}$ \\
\hline USCS Group-Lab & $\sum$ & $\frac{2}{6}$ & $\sum_{0}$ & $\sum_{n}$ & $\mid \frac{2}{6 y}$ & $\frac{5}{6}$ & $\sum_{00}$ & $\sum_{6}$ & $\frac{\infty}{\infty}$ & $\frac{4}{2}$ & $\frac{2}{6}$ & $\sum_{0}^{\infty}$ & 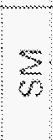 & $\frac{\sum}{\infty}$ & $\frac{5}{5}$ & $\sum_{0}$ & $\frac{3}{6}$ & $\frac{\sum}{w i}$ & $\frac{5}{6}$ & $\frac{\Sigma}{6}$ & $\sqrt{5}$ & $\sum$ & $\frac{\sum}{\infty}$ & $\frac{5}{n}$ \\
\hline Lower Depth (cm) & $m$ & - & $m$ & t & 8 & $\infty$ & $\stackrel{2}{\Omega}$ & $m^{2}$ & 8 & $m$ & $\infty$ & 8 & $\infty$ & $\$$ & 9 & $m$ & 2 & 0 & $\infty$ & $\infty$ & 3 & $\infty$ & 8 & $\infty$ \\
\hline Upper Depth (cm) & 0 & $m$ & $\infty$ & $\Leftrightarrow$ & to & 0 & 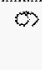 & 15 & 8 & 0 & 5 & ल & 8 & 0 & $\approx$ & ot & tor & $\varphi$ & 8 & $\infty$ & $m$ & 8 & $\infty$ & 0 \\
\hline arizon & $\frac{8}{8}$ & $\infty$ & $\infty$ & $\frac{x}{\frac{x}{v g}}$ & $\frac{9}{9}$ & $<$ & $\infty$ & 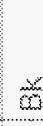 & $\infty$ & $\frac{3}{8}$ & $\frac{x}{y}$ & $\begin{array}{c}\frac{5}{x h} \\
d\end{array}$ & $\frac{\infty}{\infty}$ & $\frac{8}{6}$ & $\begin{array}{l}3 \\
3 \\
0 \\
\frac{3}{3}\end{array}$ & 2 & 6 & 8 & $\infty$ & $\infty$ & $\bar{c}$ & $\frac{9}{6}$ & 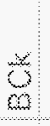 & $\infty$ \\
\hline Fleir Sample Code & $\begin{array}{l}8 \\
\frac{8}{2} \\
8 \\
8\end{array}$ & $\begin{array}{l}8 \\
8 \\
5 \\
5\end{array}$ & $\frac{2}{\frac{2}{b}}$ & $\frac{8}{8}$ & $\frac{\infty}{\infty}$ & $\frac{5}{8}$ & $\frac{\infty}{\infty}$ & $\frac{8}{8}$ & $\frac{p}{\infty}$ & $\frac{8}{\frac{8}{2}}$ & $\frac{\infty}{\infty}$ & $\frac{8}{8}$ & $\frac{8}{\infty}$ & $\frac{6}{3}$ & $\begin{array}{c}2 \\
8 \\
8 \\
6 \\
4\end{array}$ & $\begin{array}{l}8 \\
\frac{8}{8} \\
2\end{array}$ & $\begin{array}{c}\frac{1}{8} \\
8 \\
8 \\
8 \\
6\end{array}$ & $\frac{8}{8}$ & $\frac{8}{8}$ & $\frac{8}{8}$ & $\frac{8}{8}$ & $\frac{8}{8}$ & $\frac{6}{8}$ & $\begin{array}{l}9 \\
8 \\
8 \\
8 \\
8\end{array}$ \\
\hline Sample & $\ddot{v}$ & $N$ & $m$ & $\infty$ & 8 & $\infty$ & 인 & $m$ & $m$ & - & 5 & $=$ & $\frac{\infty}{m}$ & 9 & $m$ & 9 & 9 & $\infty$ & $\sqrt{2}$ & 0 & sit & $N$ & 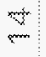 & $\omega$ \\
\hline Batch & 8 & 8 & $\infty$ & 8 & 8 & 8 & 8 & 8 & 8 & 8 & $\infty$ & 8 & 8 & 8 & 8 & 8 & 8 & 8 & 8 & 8 & 8 & 8 & 8 & 8 \\
\hline
\end{tabular}




\begin{tabular}{|c|c|c|c|c|}
\hline$p<200$ & ป & क् & 6 & 9 \\
\hline$P<440$ & 5 & 9 & 9 & is \\
\hline$P<$ 提10 & 2 & 8 & t5) & 女 \\
\hline$p<4$ & 8 & $N$ & 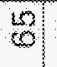 & 8 \\
\hline$P<3 / 8$ in & $\infty$ & $\begin{array}{l}9 \\
\infty\end{array}$ & $N$ & 9 \\
\hline$P<3 / 4$ in & 9 & 9 & $\infty$ & 9 \\
\hline$p<1$ wn & 8 & 8 & 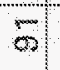 & $\Phi$ \\
\hline P<1/12-n & $\infty$ & 5 & ${ }_{15}^{15}$ & ㄷ) \\
\hline$p<2$-n & 8 & $\infty$ & 5 & $\$$ \\
\hline$P<3-i n$ & 8 & 8 & 8 & 8 \\
\hline Sitt+clay_uscs $(w 1 \%)$ & $\$$ & $\begin{array}{l}\infty \\
\sqrt{v}\end{array}$ & m & ه \\
\hline Sand_USCS $(w * \%)$ & 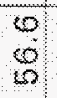 & 0 & $\mathrm{~m}$ & $\begin{array}{l}m \\
0\end{array}$ \\
\hline Gravel USCS $(W T \%)$ & $\bar{d}$ & $\begin{array}{l}0 \\
\omega\end{array}$ & $\begin{array}{l}\mathrm{d} \\
\text { L }\end{array}$ & $\begin{array}{l}6 \\
\sqrt{6}\end{array} \mid$ \\
\hline USCS Group-Lab & $\frac{2}{6}$ & $\sum_{\infty}$ & $\sum_{D}$ & $\sum_{\infty}$ \\
\hline Lower Depth (cm) & 8 & 9 & $\infty$ & 8 \\
\hline Upper Depth (cm) & $\infty$ & $\sqrt[4]{4}$ & & t) \\
\hline Horizon & 8 & $\frac{\bar{\alpha}}{\infty}$ & $\frac{\searrow}{\infty}$ & 8 \\
\hline Field Sample Code & $\begin{array}{l}\frac{8}{8} \\
8 \\
8 \\
8 \\
4\end{array}$ & $\begin{array}{l}\frac{\infty}{8} \\
\frac{8}{8} \\
\frac{8}{6}\end{array}$ & $\begin{array}{l}8 \\
8 \\
8 \\
8\end{array}$ & $\begin{array}{l}0 \\
8 \\
8 \\
8 \\
8\end{array}$ \\
\hline Sample & $\infty$ & $\infty$ & ले & " \\
\hline Batch & 8 & 8 & 8 & 8 \\
\hline
\end{tabular}




\begin{tabular}{|c|c|c|c|c|c|c|c|c|c|c|c|c|c|c|c|c|c|c|c|c|c|c|c|c|}
\hline$p<200$ & 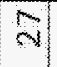 & N) & 2 & 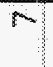 & \pm & $\frac{\mathbb{N}}{2}$ & 8 & 9 & $M$ & $\infty$ & \pm & 8 & $\mathbb{N}$ & $m$ & 5 & 48 & $Q$ & 4 & $\sqrt{7}$ & 9 & 6 & $\sqrt{2}$ & $\mathrm{~m}$ & 8 \\
\hline$p<40$ & $R$ & 8 & से & $\infty$ & $\bar{t}$ & 9 & D) & 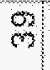 & $\begin{array}{l}\infty \\
\wp\end{array}$ & $\mathrm{m}$ & $m$ & $\frac{\pi}{8}$ & 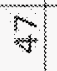 & $\mathrm{N}$ & $\begin{array}{l}3 \\
61\end{array}$ & $\frac{3}{4}$ & $\begin{array}{l}19 \\
6\end{array}$ & + & $\stackrel{\infty}{\circ}$ & 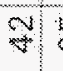 & $\stackrel{\infty}{N}$ & 8 & $\infty$ & $\infty$ \\
\hline$P<10$ & $\infty$ & $N$ & $\infty$ & 9 & $M$ & ถึ & $\mathrm{M}$ & 3 & $\infty$ & 8 & 9 & m & 8 & $\infty$ & 5 & 8 & $\stackrel{6}{L}$ & $\bar{m}$ & 8 & 6 & 9 & $\Phi$ & 8 & $\infty$ \\
\hline$<x^{2} 4$ & $\infty$ & 5 & $n$ & 2 & 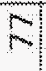 & का & $\mathrm{\infty}$ & 8 & $m$ & $M$ & 6 & 8 & 8 & $\begin{array}{c}\infty \\
\infty\end{array}$ & $\infty$ & 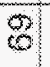 & 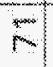 & 9 & $\$$ & 8 & $\overline{6}$ & $\vec{s}$ & 8 & 6 \\
\hline$p<3 / 8$-in & $\infty$ & $\infty$ & $\infty$ & pa & $\infty$ & $\infty$ & 8 & 8 & $\$$ & $\infty$ & $\infty$ & $\infty$ & 8 & $\frac{9}{2}$ & $\infty$ & $N_{n}$ & $\infty$ & $\infty$ & 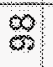 & 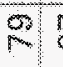 & $\infty$ & 8 & $\infty$ & $m$ \\
\hline$p<3 / 4-i n$ & $\infty$ & 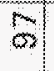 & 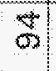 & $\infty$ & का & $\infty$ & 8 & $\mathbb{R}$ & क्षा & 5 & $N$ & $\$$ & 8 & $\%$ & 8 & $\infty$ & $\mathrm{p}$ & 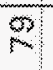 & $\Phi$ & $\bar{\sigma}$ & $\infty$ & 8 & 0 & $\$$ \\
\hline$p<1 n$ & $\infty$ & के & 18 & 8 & $s$ & 8 & $\infty$ & $\$$ & 5 & 8 & $+\infty$ & $\begin{array}{l}6 \\
\omega\end{array}$ & $\infty$ & 9 & $\infty$ & $\infty$ & $\overrightarrow{0}$ & 8 & 8 & 8 & $\infty$ & 9 & 8 & $\infty$ \\
\hline$P<11 / 2$ in & $\infty$ & $\$$ & 6 & के & $\begin{array}{c}\infty \\
\infty\end{array}$ & $\$$ & 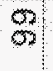 & 8 & $\infty$ & 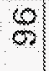 & $\infty$ & $\stackrel{m}{\infty}$ & 9 & 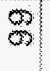 & $\infty$ & ल) & 9 & $\infty$ & 8 & 2 & F & 9 & $\infty$ & m) \\
\hline$P<2$-in & 9 & 9 & 8 & 9 & 9 & $\$$ & 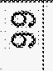 & के & $\infty$ & $B$ & $\$$ & 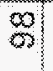 & $\infty$ & 8 & $\begin{array}{ll}\infty \\
\infty\end{array}$ & $\begin{array}{c}39 \\
01\end{array}$ & $\begin{array}{l}50 \\
\infty\end{array}$ & 5 & 8 & 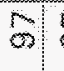 & 18 & 8 & $\infty$ & 9 \\
\hline in & 8 & 8 & 8 & 8 & 8 & 8 & 8 & 8 & 8 & 8 & 8 & 9 & 8 & 8 & 8 & 8 & 8 & 8 & 8 & 8 & 8 & 8 & 8 & 8 \\
\hline & 8 & 0 & $\infty$ & 60 & का & 8 & का & M & का & त) & ? & 0 & का & 5 & 3 & ?) & 0 & का & 0 & $\infty$ & $=$ & m & $m$ & तो \\
\hline Sitt+clay_uscs $(w \%)$ & 官 & $\sqrt{8}$ & $\dot{\nabla}$ & \pm & 8 & $\dot{d}$ & : & $\approx$ & 2 & $\dot{\nabla}$ & $\stackrel{\circ}{9}$ & $\stackrel{5}{4}$ & $\mathrm{~d}$ & की & $\mathrm{m}$ & के & $\infty$ & $\infty$ & $\curvearrowright$ & 8 & \pm & ल) & N. & 여 \\
\hline Sand_USCS (wt\%) & $\begin{array}{l}9 \\
0 \\
\text { in }\end{array}$ & $\stackrel{0}{6}$ & ำ & $\overrightarrow{5}$ & $\begin{array}{l}0 \\
5 \\
5\end{array}$ & व. & $m$ & 15 & 8 & dis & $\frac{5}{4}$ & $\begin{array}{l}\infty \\
0 \\
\omega\end{array}$ & $\begin{array}{l}5 \\
0 \\
15\end{array}$ & $\stackrel{0}{\infty}$ & $\frac{8}{15}$ & 6 & 9 & $\stackrel{\infty}{\infty}$ & $\begin{array}{l}\infty \\
8 \\
8\end{array}$ & s: & 5 & 8 & 8 & 8 \\
\hline Graveluscs (wt/ $)$ & $\stackrel{4}{0}$ & 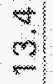 & 0 & $\frac{3}{\infty}$ & $\begin{array}{l}9 \\
0 \\
q\end{array}$ & $\frac{\vec{N}}{\mathrm{~N}}$ & d & 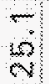 & 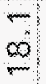 & 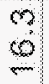 & $\begin{array}{l}- \\
0 \\
ه 1\end{array}$ & $\square$ & $\stackrel{\pi}{\infty}$ & 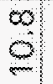 & 2 & $\bar{v}$ & $\infty$ & ल) & s] & $\frac{10}{4}$ & \$) & 40 & si & 길 \\
\hline USC & 2 & $\sum_{\omega}$ & $\frac{5}{6 n}$ & $\sum_{6}$ & $\sum_{\hat{\Omega}}$ & $\sum$ & $\sum_{\infty}$ & $\underset{\infty}{\infty}$ & $\sum_{n}$ & $\sum_{\infty}$ & $\sum$ & $\sum_{\infty}$ & $\sum_{0}$ & $\sum$ & $\sum_{0}$ & $\frac{\sum_{0}}{3}$ & $\sum_{0 \Omega}$ & $\sum_{0}^{2}$ & $\frac{5}{6}$ & $\frac{5}{\infty}$ & $\frac{5}{\infty}$ & $\frac{\sum}{n}$ & $\frac{\Sigma}{\delta S}$ & $\frac{2}{6}$ \\
\hline Lower Depth (cm) & 2 & $\infty$ & 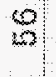 & $\bar{m}$ & 8 & 8 & 9 & $\begin{array}{l}\infty \\
\infty\end{array}$ & S & $\frac{A}{d}$ & 9 & एक & $\stackrel{b}{N}$ & 9 & vै & 8 & $\begin{array}{l}35 \\
\infty\end{array}$ & 8 & 눠 & ले & 8 & $=$ & 8 & 8 \\
\hline Upper Depth (cm) & 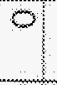 & \pm & $\infty$ & 18 & 5 & $\infty$ & $\stackrel{8}{=}$ & $\frac{10}{4}$ & \begin{tabular}{l}
0 \\
0 \\
$\infty$ \\
\hdashline
\end{tabular} & $\underset{\mathrm{D}}{D}$ & $\frac{N}{v}$ & $\begin{array}{l}9 \\
4\end{array}$ & $\vec{\infty}$ & 0 & & $\mathbb{N}$ & 5 & 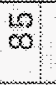 & $\frac{8}{8}$ & s? & $\begin{array}{ll}9 \\
3\end{array}$ & o & 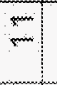 & 잉 \\
\hline rizon & $\frac{8}{4}$ & $\frac{9}{\infty}$ & $\begin{array}{l}\frac{1}{0} \\
\text { on }\end{array}$ & $\begin{array}{c}0 \\
\frac{0}{\alpha}\end{array}$ & $\frac{8}{\frac{8}{m}}$ & $\frac{\vec{E}}{\infty}$ & $\frac{\frac{m}{0}}{\frac{0}{m}}$ & $\begin{array}{c}a \\
\mathrm{y} \\
\frac{\mathrm{p}}{\mathrm{p}}\end{array}$ & $\underset{\mathrm{c}}{\mathrm{c}}$ & $\frac{a}{\square}$ & 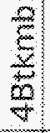 & $\frac{5}{\frac{2}{\infty}}$ & $\begin{array}{l}\frac{1}{2} \\
\frac{8}{w}\end{array}$ & $\frac{2}{x}$ & $\stackrel{\square}{\infty}$ & 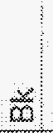 & $\vec{c}$ & $\frac{5}{6}$ & $\underset{6}{0}$ & $\stackrel{8}{\mathbb{Q}}$ & $\frac{0}{6}$ & $\underset{\infty}{\infty}$ & $\frac{6}{\infty}$ & के \\
\hline Field Sample Code & $\frac{5}{5}$ & $\begin{array}{l}\frac{1}{6} \\
\frac{\infty}{0} \\
8 \\
0 \\
0\end{array}$ & $\begin{array}{l}\frac{9}{8} \\
\frac{8}{8} \\
\frac{8}{n}\end{array}$ & $\begin{array}{l}5 \\
0 \\
0 \\
8 \\
8 \\
6\end{array}$ & $\frac{8}{8}$ & $\begin{array}{l}\infty \\
0 \\
9 \\
8 \\
0 \\
\infty\end{array}$ & $\begin{array}{l}\frac{m}{0} \\
\frac{8}{0} \\
\frac{8}{\infty} \\
\frac{0}{3}\end{array}$ & $\frac{\infty}{\frac{\infty}{8}}$ & $\begin{array}{l}\frac{8}{8} \\
\frac{8}{8} \\
\frac{8}{0}\end{array}$ & $\begin{array}{l}\frac{0}{8} \\
\frac{8}{8} \\
\frac{8}{n}\end{array}$ & $\frac{5}{\infty}$ & $\frac{\frac{w}{b}}{\frac{b}{8}}$ & $\frac{m}{\frac{m}{8}}$ & $\frac{5}{8}$ & $\frac{8}{8}$ & $\frac{d}{8}$ & $\begin{array}{l}\frac{5}{p} \\
\frac{9}{0} \\
\frac{0}{2}\end{array}$ & $\frac{8}{8}$ & $\begin{array}{l}\frac{8}{8} \\
\frac{8}{8} \\
\frac{8}{x}\end{array}$ & $\begin{array}{l}\frac{9}{8} \\
\frac{8}{6} \\
0\end{array}$ & $\frac{8}{8}$ & $\begin{array}{l}\infty \\
8 \\
0 \\
0 \\
0 \\
0\end{array}$ & $\begin{array}{l}\frac{8}{8} \\
8 \\
\frac{8}{8} \\
\frac{8}{n}\end{array}$ & $\begin{array}{l}3 \\
8 \\
8 \\
8 \\
\frac{8}{8} \\
6\end{array}$ \\
\hline Sample & 8 & $m$ & $\infty$ & $\infty$ & 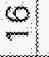 & $\infty$ & 10 & $N$ & $\stackrel{\infty}{\infty}$ & $\mathrm{N}$ & $m$ & 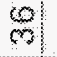 & $m$ & 9 & $\mathrm{~N}$ & $?$ & 8 & $\frac{\infty}{=}$ & $y$ & 10 & 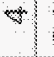 & है। & $m$ & $\stackrel{\infty}{\curvearrowright}$ \\
\hline $\operatorname{tch}$ & 8 & 8 & 8 & $\mathrm{Q}$ & 8 & 8 & 8 & 8 & 8 & 8 & 8 & 8 & 8 & 8 & 8 & 8 & 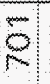 & 8 & 8 & 8 & 5 & 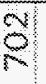 & 8 & 8 \\
\hline
\end{tabular}




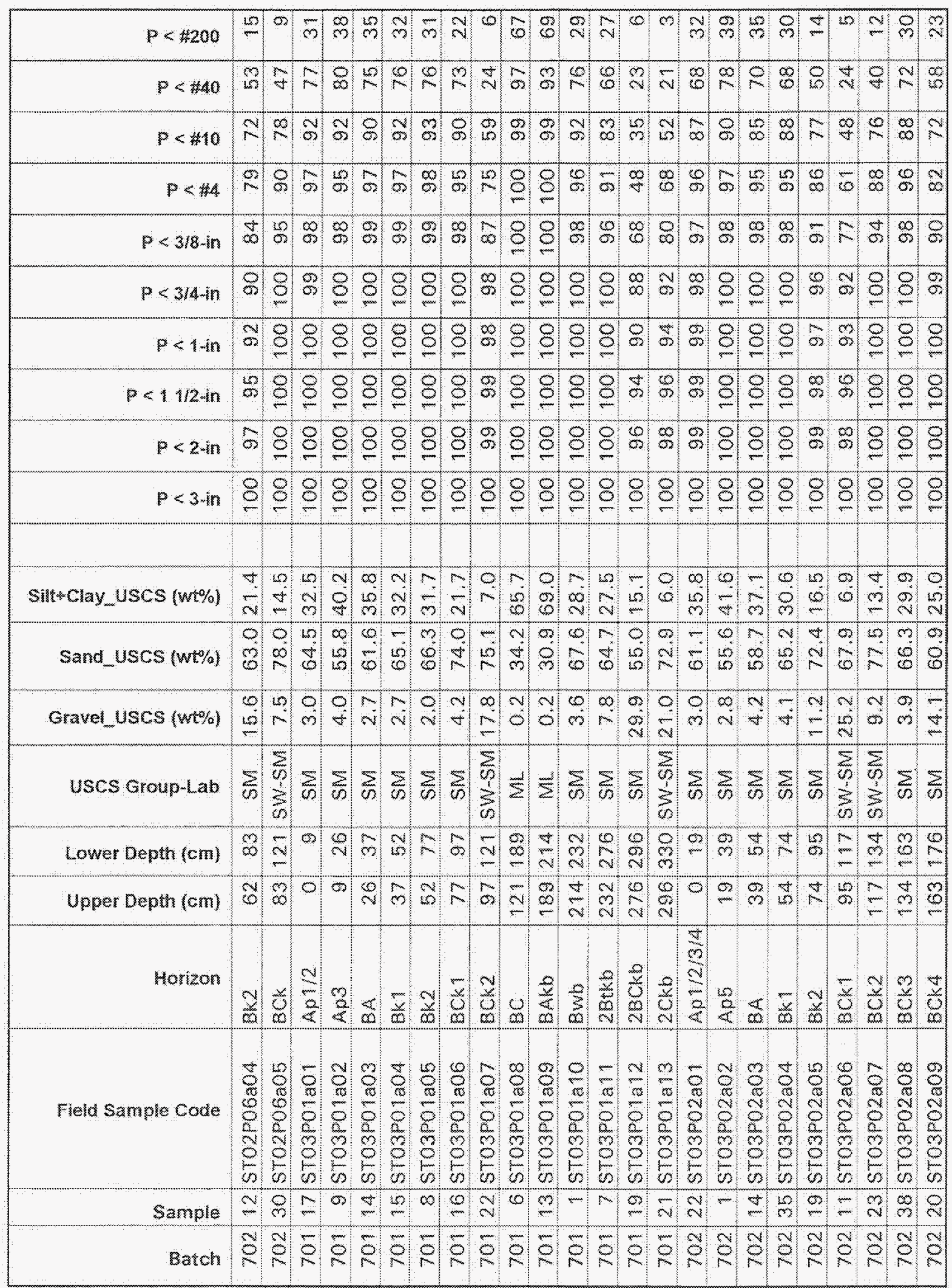




\begin{tabular}{|c|c|c|c|c|c|c|c|c|c|c|c|c|c|c|c|}
\hline$P<1200$ & 8 & $d$ & 9 & 8 & 2 & $\frac{2}{2}$ & $\infty$ & $\mathrm{N}$ & 2 & $\stackrel{45}{\sim}$ & 9 & $\stackrel{65}{m}$ & 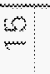 & $m$ & 5 \\
\hline$p<40$ & $\infty$ & $\infty$ & 20 & 8 & 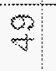 & 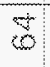 & 50 & 8 & 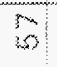 & $\infty$ & 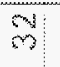 & 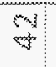 & 8 & 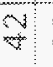 & 8 \\
\hline$p<140$ & 8 & $\bar{d}$ & का & 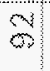 & $\infty$ & 12 & $\infty$ & $\infty$ & $\infty$ & 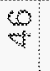 & $m$ & 5 & 8 & 5 & 8 \\
\hline$p<3$ & 8 & 8 & $\$$ & ol & 5 & 8 & के & $\begin{array}{l}10 \\
0\end{array}$ & 9 & $\infty$ & $\%$ & 5 & 8 & 8 & 8 \\
\hline$p<38$. $m$ & 8 & $\phi$ & $\sigma_{0}$ & $\mathscr{g}$ & 8 & $\$$ & 8 & $\infty$ & 9 & $m_{n}$ & 8 & $\phi$ & $\ddot{\infty}$ & $\infty$ & 3 \\
\hline$<<3 / 4-\mathrm{in}$ & 8 & 8 & 8 & 8 & 8 & 8 & 8 & 8 & 8 & $\infty$ & 8 & $\infty$ & $\infty$ & 8 & ol \\
\hline$p<1+1 n$ & 8 & 8 & 8 & 8 & 8 & 8 & 8 & 8 & 8 & $m$ & 8 & $\infty$ & 8 & $\infty$ & 9 \\
\hline$p<1 \| 2 \pi n$ & 8 & 8 & 8 & 8 & 8 & 8 & 8 & 8 & 8 & $\infty$ & 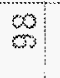 & 8 & 8 & 8 & 8 \\
\hline$p<2$ in & 8 & 8 & 8 & 8 & 8 & 8 & 8 & 8 & 8 & 9 & 2 & 8 & 9 & 8 & 9 \\
\hline$p<3-88$ & 8 & 8 & 8 & 8 & 8 & 8 & 8 & 8 & 8 & 8 & 8 & 8 & 8 & 8 & 8 \\
\hline sith Clay USCs (wr\%) & $\begin{array}{l}\infty \\
6 \\
0\end{array}$ & $\frac{0}{d}$ & 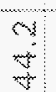 & 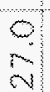 & $\stackrel{9}{\square}$ & 6 & $\frac{t}{i}$ & 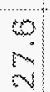 & 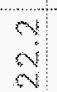 & $\frac{2}{d}$ & 5 & $\frac{m}{\sigma}$ & 8 & $\stackrel{\mathrm{s}}{\mathrm{s}}$ & $\stackrel{0}{0}$ \\
\hline Sand Uscs (wo & $\begin{array}{l}\text { क्र } \\
\text { ले }\end{array}$ & 8 & $\frac{d}{b}$ & 9 & 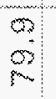 & 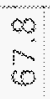 & $\begin{array}{l}158 \\
N\end{array}$ & $\begin{array}{l}6 \\
\infty \\
0\end{array}$ & $\frac{8}{2}$ & $\frac{\infty}{4}$ & $\frac{\infty}{f}$ & 0 & $\begin{array}{l}6 \\
6 \\
6 \\
5\end{array}$ & $\stackrel{6}{6}$ & 9 \\
\hline Grave USCS \{moth & $\overline{0}$ & $\begin{array}{l}0 \\
\curvearrowright\end{array}$ & 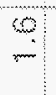 & $\begin{array}{l}\omega \\
\infty\end{array} \mid$ & 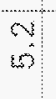 & 6 & 5 & $\begin{array}{l}\infty \\
\infty\end{array}$ & 3 & $\vec{r}$ & $\begin{array}{l}3 \\
6\end{array}$ & $\frac{a}{8}$ & $\hat{N}$ & 8 & 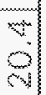 \\
\hline USCS Grouphab & $\sum$ & $\sum_{6}$ & $\sum_{\infty}$ & $\sum$ & $\underset{\substack{0 \\
0}}{3}$ & $\sum$ & $\sum_{n}$ & $\sum_{\infty}^{\infty}$ & $\frac{2}{6}$ & $\sum_{6}$ & $\sum_{\infty}$ & 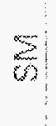 & 2 & $\sum_{\infty}^{\infty}$ & 2 \\
\hline Lower Depth (cm) & 2 & 8 & क् & $\stackrel{0}{4}$ & 8 & 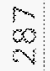 & 5 & $\frac{5}{2}$ & $m$ & $\mathrm{~m}$ & 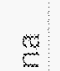 & 胫 & $\underline{m}$ & e & $\mathrm{g}$ \\
\hline Upper Depth (cm) & $\infty$ & $\frac{8}{2}$ & 8 & 8 & $\frac{6}{v}$ & $\frac{1}{\infty}$ & $\begin{array}{l}\infty \\
\infty \\
\infty\end{array}$ & 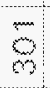 & $\frac{m}{m}$ & g & 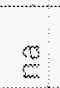 & 2 & 8 & $\underline{m}$ & $\mathrm{E}$ \\
\hline Morizon & $\frac{2}{3}$ & $\frac{8}{6}$ & $\frac{9}{2}$ & $\frac{9}{6}$ & $\frac{0}{6}$ & $\frac{2}{\frac{3}{6}}$ & $\frac{a}{a}$ & $\frac{3}{6}$ & $\frac{9}{\frac{0}{m}}$ & $\mathrm{~m}$ & $\mathrm{~m}$ & 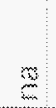 & $\underline{v}$ & = & 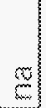 \\
\hline Field Sample Code & $\begin{array}{l}\frac{8}{80} \\
\frac{8}{8} \\
\frac{8}{6} \\
\frac{8}{6}\end{array}$ & $\begin{array}{l}\frac{m}{6} \\
\frac{5}{6} \\
\frac{m}{6}\end{array}$ & $\begin{array}{l}\infty \\
8 \\
8 \\
8 \\
b\end{array}$ & $\begin{array}{l}m \\
\frac{m}{p} \\
\frac{p}{m} \\
\frac{m}{m}\end{array}$ & $\begin{array}{l}\frac{w}{4} \\
\frac{8}{6} \\
\frac{8}{6}\end{array}$ & $\begin{array}{l}\frac{1}{n} \\
8 \\
8 \\
8 \\
\frac{8}{8}\end{array}$ & $\frac{0}{8} \frac{8}{8}$ & $\frac{m}{b}$ & $\frac{\frac{\infty}{8}}{\frac{8}{8}} \frac{}{\frac{8}{b}}$ & 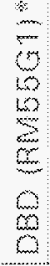 & $\begin{array}{l}\frac{k}{5} \\
\frac{6}{6} \\
\frac{2}{12} \\
\underline{5} \\
0 \\
0 \\
0\end{array}$ & $\frac{\infty}{Q}$ & $\frac{1}{8}$ & $\frac{b}{b}$ & 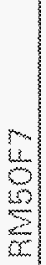 \\
\hline Sample & 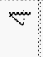 & 2 & m. & 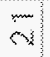 & 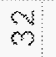 & $\infty$ & 8 & 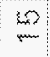 & $\infty$ & 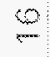 & \% & $n$ & 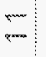 & 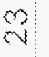 & लl \\
\hline Batch & $m$ & $\hat{\rho}$ & $p$ & 8 & 8 & 8 & 8 & 8 & 8 & 8 & $\mathrm{p}$ & $\frac{2}{8}$ & $\mathrm{~b}$ & 8 & 8 \\
\hline
\end{tabular}




\section{APPENDIX E}

\section{NUMERICAL AGE DATA}




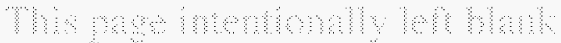


Samples for Carbon-14 (C14) and Optical Stimulated Luminescence (OSL) analyses were collected at the Area 3 RWMS from Soil Trench Three (STO3) on February 27, 1997, and September 27, 1997, respectively. Sample locations are shown on Figure E-1.

The C14 sample (Sample ST03Z2) consisted of several milligrams of charcoal that were separated from alluvium. The charcoal fragments were sent to Beta Analytic, Inc., for Accelerator Mass Spectrometry (AMS) analysis. Results of the C14 analysis are presented in the attached report from Beta Analytic Inc.

Optical Stimulated Luminescence samples consisted of alluvial and eolian deposits. Samples were collected using core tubes that were 1 in $(2.54 \mathrm{~cm})$ in diameter and 14 in $(35.6 \mathrm{~cm})$ long. Although the use of such a coring apparatus permits sample collection during daylight hours, samples were collected after twilight and were shielded by a black cloth to ensure that there was no exposure to sunlight. The samples were sent to the University of Utah Center for Applied Dosimetry for analysis (see attached report). Figure E-2 shows the numerical ages as a function volumetric water content.

The charcoal fragments (Sample ST03Z2) collected immediately adjacent to OSL Sample 2-2 (Figure E-I) yielded a conventional $\mathrm{Cl} 4$ numerical age of $10,530 \pm 60$ years before present. Figure E-3 is a synthesis of Late-Pleistocene, Holocene, and possible future climatic variations based on the work of Spaulding (1985). This figure shows an increase in temperature from a minimum during the last glacial stade to a hypsothermal during the early middle Holocene, natural cooling to the present-day temperature, a sharp hypothetical increase in temperature associated with "greenhouse" warming, followed by natural cooling toward a hypothetical glacial stade beyond 10,000 years hence. From about 11,000 to 10,000 years ago, summer precipitation may have been as much as 50 percent higher than at present, although annual amounts in the northern Mojave Desert probably were within 20 percent of current values. A volumetric water content of approximately 0.20 would yield an OSL numerical age that coincides with the $\mathrm{C} 14$ age. Based on previous studies (Spaulding, 1985), a volumetric water content in this range over the past 12,000 years is not unreasonable for the deposits where the OSL samples were obtained. 


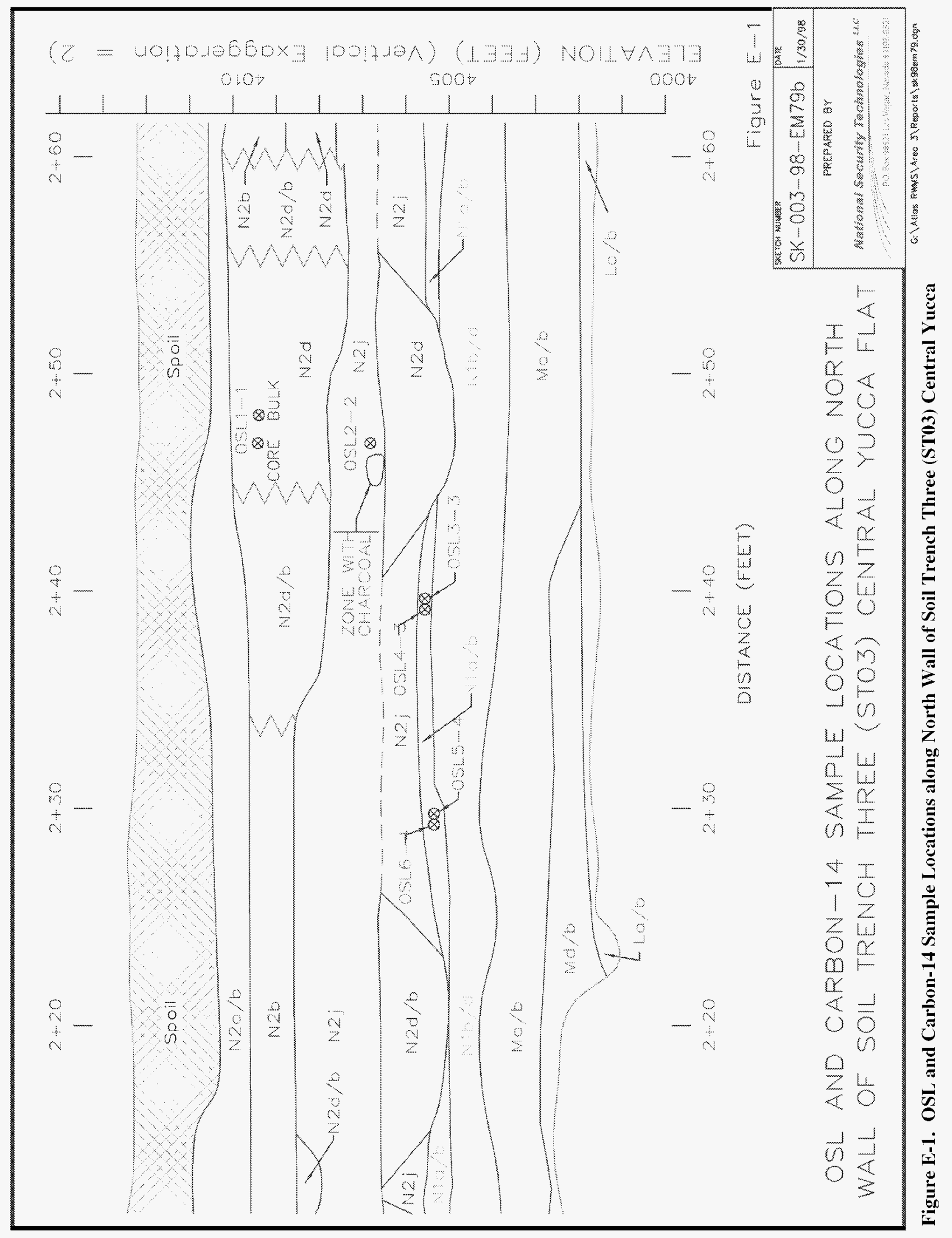




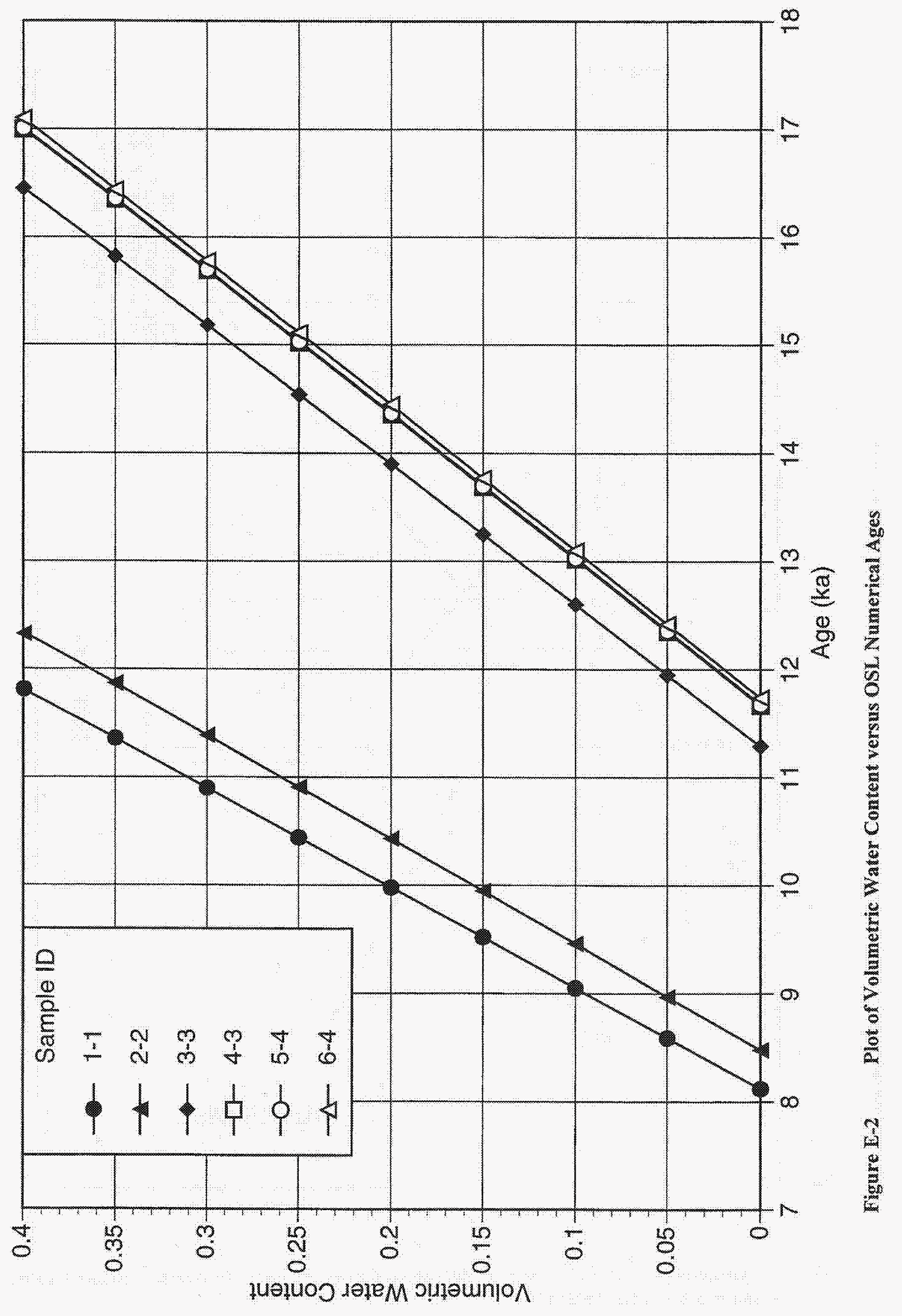




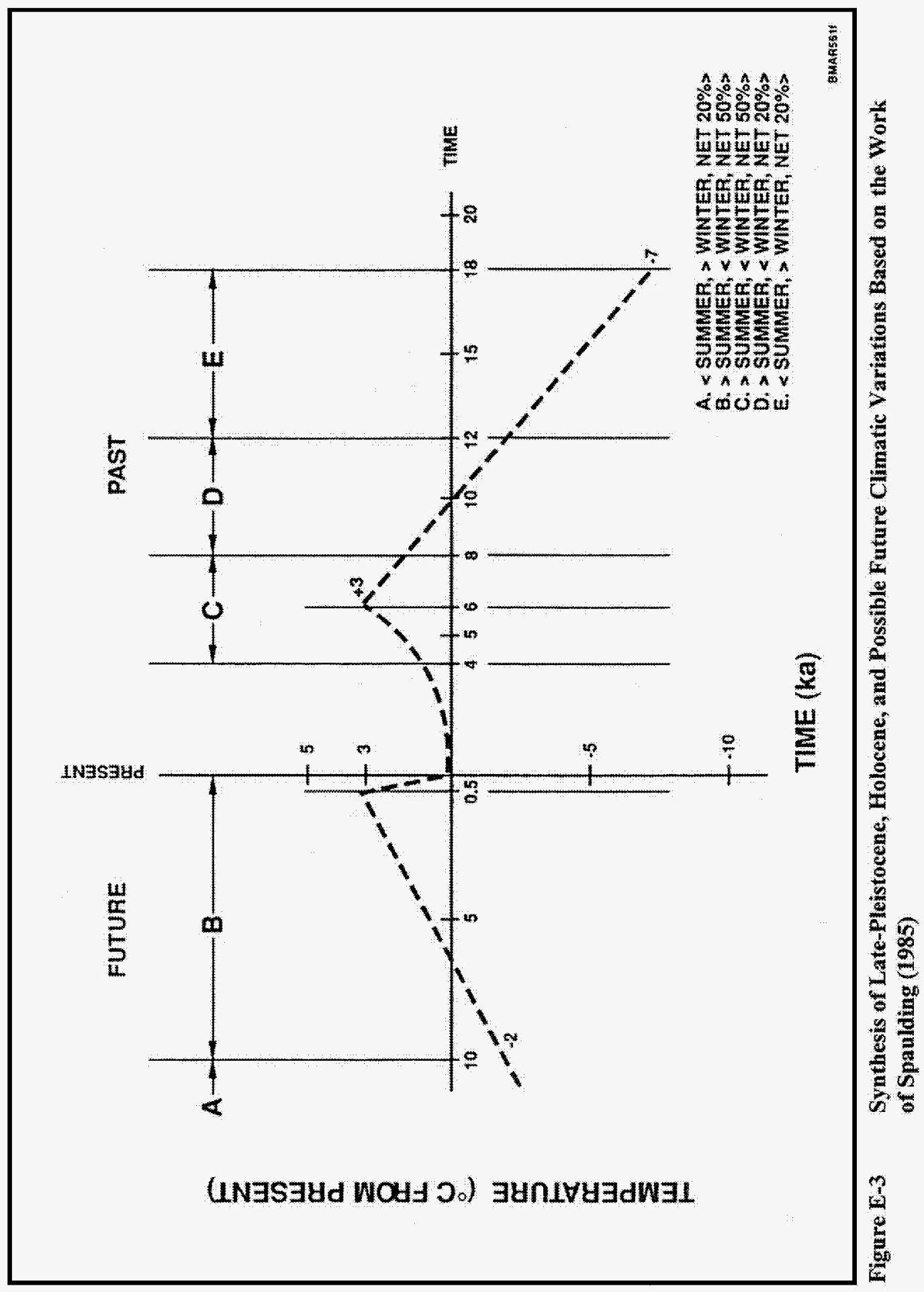




\section{BETA ANALYTIC INC. \\ RADIOCARBON DATNG SERVICES}

DI MURRY A TANERS

RONALO E. HATMED

MI DAROEN $G$. HOOD

Loboratory Monager

Directors

CHRSTOMHER PATRICK

TERESA A. ZUKO MLLLR

Associofe Managers

September 8, 1997

Bectel Nevada:

P.O. Box 9852

Las Vegas, NV 39193

Please find enclosed the radiocarbon dating results for one charcoal sample (STO322) which was submitted on August 21. The sample was very small and was analyzed by the AMS method, on the ADVANCE basis. Pretreatment, CIA content measurement and age calculation went nomally. The quoted errors represent 1 sigma statistics. Since these errors cannot include uncertainties outside of those which can be quantified during measurement, it is best to consider them as minimum quotes.

Literature discussing the generalities of analysis and calendar calibration are enclosed. The "Analytical Procedures and Final Report" discrusion shovid answer most questions about the report and results. If you have any specific questions, please do not hesitate to contact us.

The cost of the analysis was charged to your VISA card. A receipt is enclosed. Thank you.

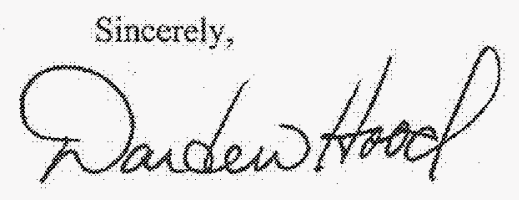

4985 SW TA COURT MAMI R 33 SSUSA

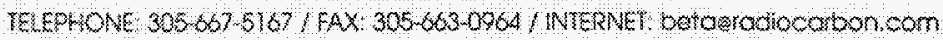

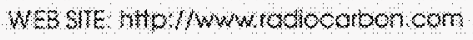




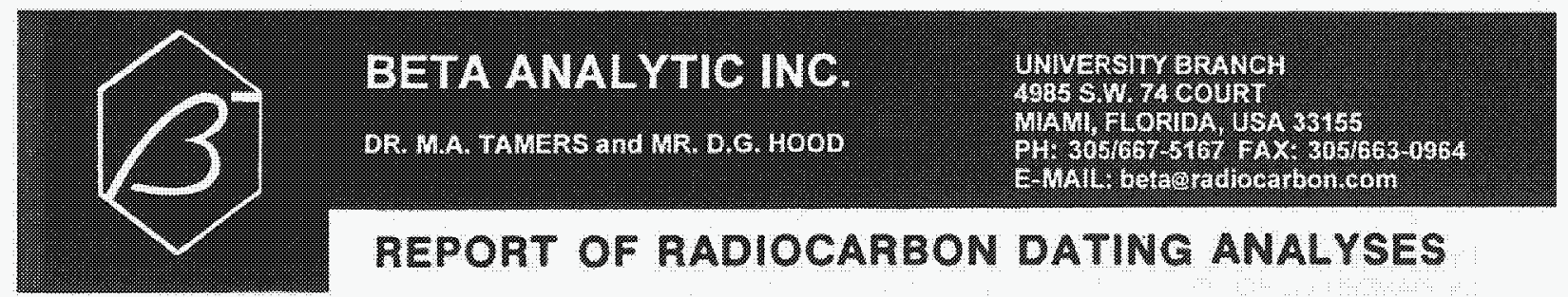

mor:

DATE RECEWED:

DATE REPOTTEO:
August 21,1997

september 8, 199 ;

\begin{tabular}{|c|c|c|c|}
\hline Sample Data & $\begin{array}{l}\text { Measured } \\
\text { CA Age }\end{array}$ & $\begin{array}{c}\text { C13/012 } \\
\text { Patio }\end{array}$ & $\begin{array}{l}\text { Conventional } \\
\mathrm{CH} A \mathrm{Age}\end{array}$ \\
\hline
\end{tabular}

Beta-108347

$10550+1-608 p$

$-26.20 / 00$

$10530+1-6080$

SAMPLE : STO3Z2

ANALYSIS: ADVANCE ANS (LLNL)

MATERIAL/PRETREATMENT:(chatred matertal): acid/alkal//acto

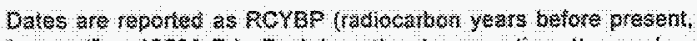

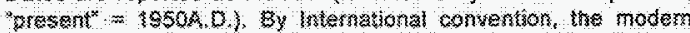

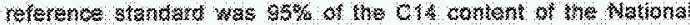

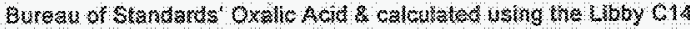

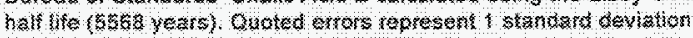

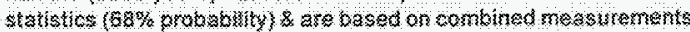

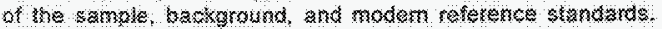

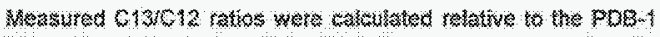

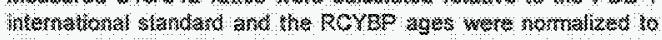

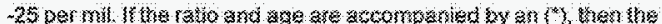

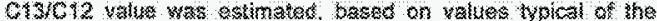

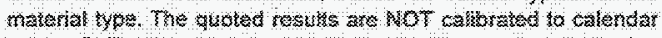

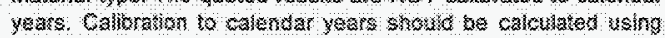
the canxertional of age: 
BETA ANALYMU MO.

RAUKOCARBON DATMG LABORATORY

CALMRATED CHADTNG RSSULTS

Calbrations of radiocatbon age determinations are appled to conver BP resuls to

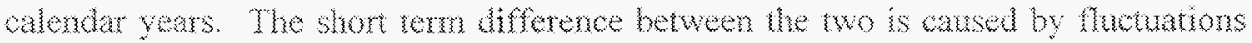
in the belomanetic modulation of he galactic cosmic abiation and, recenty, large scale buming at tossil hels and nuclev devices testing. Geomagnetic variations are the probable cause of longer term diperenos.

The parameter wow for the corrections have beer obuined though precise analyses

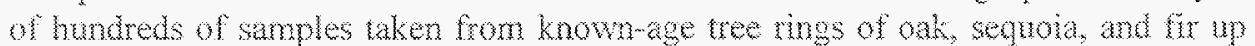
to $7,200 \mathrm{BP}$. The parameters for older samples, wp to $22,000 \mathrm{BP}$ as well as or all mathe samples, have been infered hom other evidence. Calbutans are presenty provided for terestrial samples to about $10,000 \mathrm{BP}$ amo marine samples to about $8,300 \mathrm{BP}$

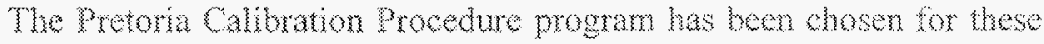

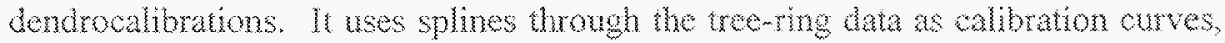
which chmintes a large part of the statiotol scatter of the actual data pomts. Whe spline calbration alows adustment of the average wurve by a gantifed choseness of hit parameter to the measued data points. On the folowing caboration curves the solu bars represen one sygma statisties (6\%\% probabiliy) and the holow bas pepresen two sigma station $195 \%$ probablity). Marine arbonate samples that

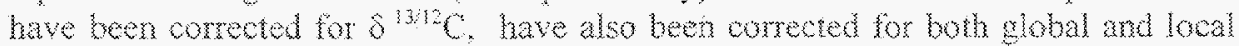
geograbic reservoir efects (as publshed in Radocabon. Volume 35, Number 1993 ) prior to the cabration. Marine cabonates that hav not ben corected for $5^{2} \mathrm{C}$, have been adusted by an asumed value of $0 \%$ in adition to the reservor corectons. Reservor conections for tresh water carbonates are usualy whinowa and are generally not acounted tor in those whbratons th the absence of

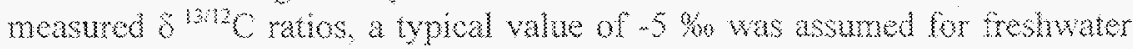
carbonates. There are separate calbration data for the Nonthern and sowhern

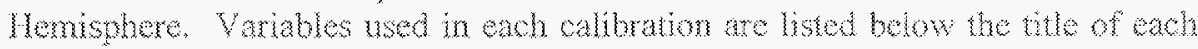
calbration page.

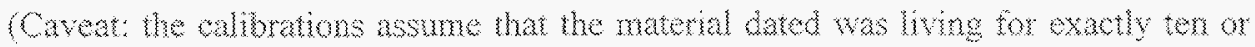

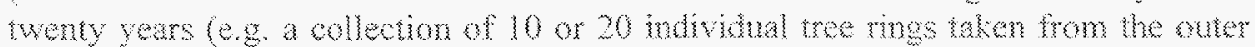
porton of a ree that was cut dowa to produce the smple in the (wane dated).

For other materials. the waximum and minmum cabrakd ase ranges gren by the computer progran are uneernin. The possbility of an "ol wood efeet" must also be considered, as well as the potental inchion of some younger matrat he the total sample. Since the vast majorty of samples dated probaby will not full the

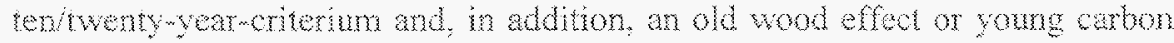

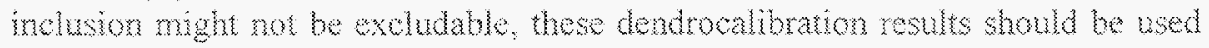
ony for illustante purposes. In the case of carbondes, rasemom corration is

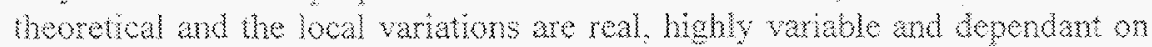
movenewe. The age ranges and. ospecially, the intercept ages generated by the mogran must be consibred as appoxitatons) 
Report on OSL Dating of Quartz Sands From Soil Trench Three (ST03)

Southern Yucca Flat, Nevada.

\author{
E.H. Haskell
}

University of Utah, Center for Applied Dosimetry, 729 Arapeen Dr. Salt Lake City, UT 84108

Nine samples which had been taken from Soil Trench Three (ST03) Southern Yucca Flat, Nevada were received by the Center for Applied Dosimetry. Six of the samples, 1-1,2-2, 3-3, 4-3, 5-4 and 6-4 were supplied for Optically Stimulated Luminescence (OSL) dating; three others, 1B, 2B, 3b and $4 \mathrm{~B}$ were collected for gamma ray spectroscopy measurements. OSL sands averaged approximately $200 \mathrm{~g}$ while bulk sands averaged $.5 \mathrm{~kg}$.

\title{
Materials and Methods
}

Gamma ray spectrometry measurements were carried out on the bulk samples according to the method of Lloyd (1976) with each sample placed between two 8-inch $(20-\mathrm{cm}) \mathrm{NaI}$ detectors. Conversion from activities to dose rates was as described by Aitken (1985) as was attenuation due to water content and beta attenuation as a function of grain size.

Cosmic ray dose rates were calculated using the method of Prescott and Stephan (1982) considering latitude, longitude and sample depth.

Samples were sieved into grain size fractions of 75 to $106 \mu \mathrm{m}$ and treated in concentrated (37\%) $\mathrm{HCL}$ in an ultrasonic bath at $55^{\circ} \mathrm{C}$ for 40 minutes and then rinsed three times in distilled water in an ultrasonic bath for 60 seconds. The samples were then etched in concentrated (48\%) HF for 30 minutes while stirring at room temperature and then rinsed in distilled water as above followed by treatment in concentrated $\mathrm{HCL}$ for 5 minutes at $55^{\circ} \mathrm{C}$ in an ultrasonic bath. Following HCL treatment samples were rinsed three times in distilled water in an ultrasonic bath for 60 seconds each. Sodium polytungstate heavy liquid (SOMETU-US 5659 Nobel Ave. Van Nuys, CA 91411) was used for speparation of quarz from the heavy mineral fractions.

Quartz measurements were carried out on a Daybreak/Utab 100 TL reader (Custommanufactured to University of Utah specifications by Daybreak Nuclear and Medical Systems, Inc, 50 Denison Drive, Guilford, CT 06437) equipped with a 9635QA photomultiplier tube, a trifrucated fiber optic input and on-plate beta irradiation from a 0.21 Gy s ${ }^{-1} 60 \mathrm{mCi}$ Sr-90/Y-90 beta source (Isotope Products Laboratories, 1800 North Keystone St. Burbank California, 91504.). Measurements were made using $514.5 \mathrm{~nm}$ 
(2.41eV) stimulation from an Ar-ion laser (Model 909, American Laser, $18325.3850 \mathrm{~W}$. Salt Lako Cily, UT) with four $7-59$ filters (Coming glasses, avalable from Kopp Glas Inc, 2108 Pamer Stwet, Mitsburgh, PA 15218) and one UGll flter (Schot glass, available from Schot Glass Technologies Tho, 400 York Ave., Duryea, PA 18642 in front of the photomuthpler tube. Laser input was fitered wib a narrow (Inm) band-pass fiter (Filter D 1-515F, Corion Corporation, 73 Jefrey Av. Holliston, MA 01746-2082).

Samples were analyzed using an OSL measurement protocol simlar to that developed by Murray and Robers (M. Aitken, presonal communication).

The underlying principle of the OSL technique used lies in the fact that OSL of guartz can undergo significant changes in sensitivity with repeated readout. These changes complicate single aliquote dating methods because of heat induced changes in the population of luminescence centers. Repeated application and readout of the same dose of mididion may result in the same number of clectrons being tapped wh each cycle, however, readout of the signal during trap emptying will resut in different signal intensities depending on the number of luminescence centers avalable for recombination with the released electrons. The change in luminescent center population in quart results from the sample pre-heating required to empty low stablity taps. Since the population of luminescence centers responsible for emission from the $110^{\circ} \mathrm{C}$ T peak of quart is the same population responsible for emission with $\mathrm{OSL}$, the $10^{\circ} \mathrm{C} \mathrm{L}$ peak can be used as monitor for the sensitivity of the OSL signal.

Tf no change in censtivity of a sample occurs dung readout the ratio of the readout of the initial OSL due to accumulation of the paleodose will be proportion to the OSL sbained from shine-down of a subequent regeneratve dose. If the two readours are identical and assuming no change in sensitity) then the paleodose is equal to the regenerative dose (also assuming that shallow traps he been cruptid simulary in bot shine downs).

Untorunately there is uswaly a change in sensityity between each shine-town for reasone given above. To corect for this change in sensitvity we used the tollowing analytical procedure. For our measurements, Th output at $100^{\circ} \mathrm{C}$ was nomalized to the inival TL readout of the first cycle obtained in step 4 , below. All subsequent Th measurements were nommized to this wital whe. All OSL measurements were ikewise nomalized to the values of the trot OSL shine down in step 2. Since the frrst TL measurement is faken after the frrt shine-down, with no interposing preheat reathents, the luminescence center populaton for both of these should be identical. The relative center population at the initial shine-down is known from ths measurement of $T L$ output, and the relative center population for the shine-down of each regeneratue dose is obtained by measung subecuent TL output from the $110^{\circ} \mathrm{CT}$ peak. By ploting the relativ OSL oupu versus the relatye $T L$ output for each regenerative shine-down, and then extrapolating back to the OSL intercept where the TL tralue is equal to 1, a scaling factor can be obtaned for 
correcting for sensitivity change between the initial OSL shine-down of the paleodose and the following shine-down of the regenerative dose. The paleodose is determined as follows:

$D=A * R / S$

where

$\mathrm{A}=$ the laboratory applied dose (Gy)

$R$ = the ratio of the OSL output from the paleodose to that from the labotatory applied dose, $S=$ the scaling factor determined as described above.

The measurement steps are as follows:

(1) preheat for 10 seconds at $290^{\circ} \mathrm{C}$;

(2) shine-down at $120^{\circ} \mathrm{C}$ to measure (and remove) the OSL;

(3) administer regenerative dose using a value near to the expected paleodose;

(4) preheat again, measuring the $110^{\circ} \mathrm{CTL}$ peak as the temperaure rises;

(5) Continue from step 2 for a total of 5 cycles, using the same regenerative dose in each cycle. The natural OSL is measured in the first step 2, and regenerated OSL in step 2 of subsequent cycles. 


\section{Determination of Senshunly Scaing Factor}

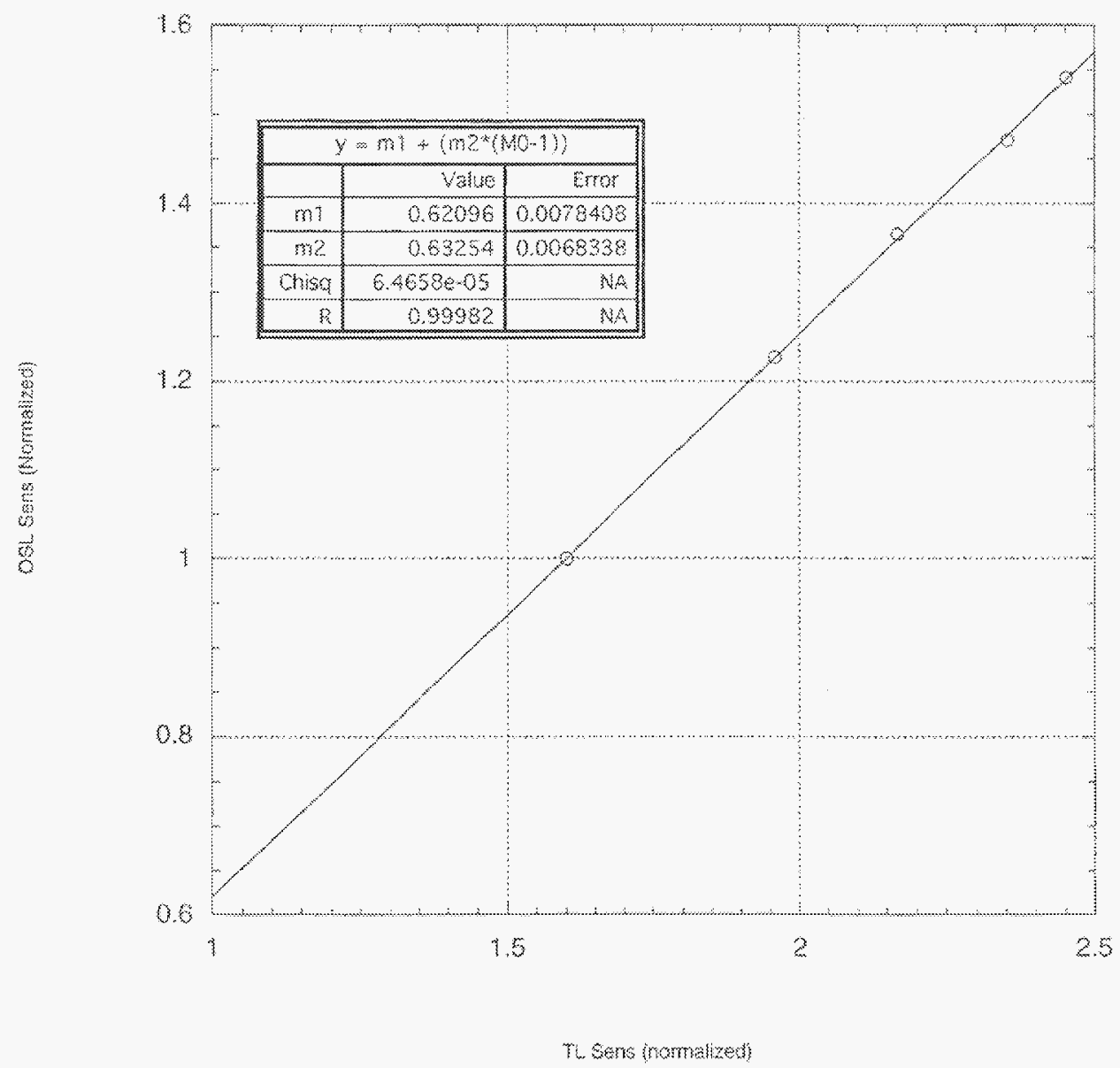

Figure E-4. Detemmaton of sensitity swang hotor. Solme

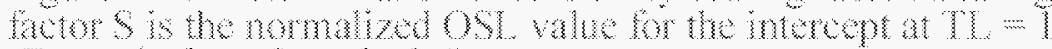
(Exaruple hom sample 6mis

\section{Resples:}

\section{Packground rose rates:}

\begin{tabular}{|c|c|c|c|c|c|c|c|c|}
\hline Cone & $A=-228$ & \pm & $K-40$ & \pm & Mn-222 & $\leq$ & Th-22 & 4 \\
\hline 18 & 1.445 & 0.035 & 24.355 & 0.785 & 1.315 & 0.049 & 1.470 & 0.014 \\
\hline $2 B$ & 1.490 & 0.057 & 20.615 & 0.389 & 1.345 & 0.021 & 1.450 & 0.014 \\
\hline 38 & 1.505 & 0.042 & 21.350 & 0.016 & 1.360 & 0.021 & 1.530 & 0.009 \\
\hline $4 B$ & 1.475 & 0.043 & 20.675 & 0.026 & 1.330 & 0.021 & 1.490 & 0.019 \\
\hline
\end{tabular}

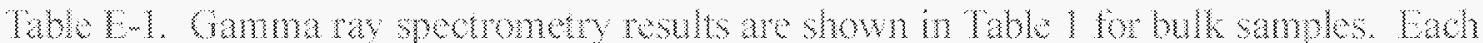
value is the mon of tro soparte mosuroments. Vames are in PCIg. 


\begin{tabular}{|c|c|c|c|c|c|c|c|c|c|}
\hline Lat & Long & $\begin{array}{c}\text { Elev } \\
(\mathrm{km})\end{array}$ & $\begin{array}{l}\text { Depth } \\
(\mathrm{m})\end{array}$ & $\begin{array}{c}\text { Ef } \\
\text { Dens }\end{array}$ & $\begin{array}{l}\text { Geo. } \\
\text { Mag. } \\
\text { Lat. }\end{array}$ & $\begin{array}{c}\text { Sott } \\
\text { (mGy/ } \\
\mathrm{ka})\end{array}$ & $\begin{array}{c}\text { Hard } \\
\text { (moyl } \\
\mathrm{ka})\end{array}$ & $\begin{array}{c}\text { Tot } \\
(\mathrm{mcy}) \\
\mathrm{ka})\end{array}$ & Samp. \\
\hline 37 & -116 & 1.2 & 0.0 & 1.45 & 44 & 110 & 232 & 342 & \\
\hline 37 & -116 & 1.2 & 0.1 & 1.45 & 44 & 75 & 229 & 304 & \\
\hline 37 & -116 & 1.2 & 0.2 & 1.45 & 44 & 49 & 226 & 275 & \\
\hline 37 & -116 & 3.2 & 0.3 & 1.45 & 44 & 30 & 223 & 253 & \\
\hline 37 & -116 & 1.2 & 0.4 & 1.45 & 44 & 18 & 220 & 238 & \\
\hline 37 & -116 & 1.2 & 0.5 & 1.45 & 44 & 9 & 217 & 227 & \\
\hline 37 & -116 & 12 & 0.6 & 1.45 & 44 & 4 & 215 & 219 & \\
\hline 37 & -116 & 1.2 & 0.7 & 1.45 & 44 & 1 & 212 & 213 & \\
\hline 37 & -116 & 1,2 & 0.8 & 1.45 & 44 & 0 & 209 & 209 & $1-1$ \\
\hline 37 & -116 & 1.2 & 0.9 & 1.45 & 44 & 0 & 207 & 206 & \\
\hline 37 & -116 & 1.2 & 1.0 & 1.45 & 44 & 0 & 204 & 203 & \\
\hline 37 & -116 & 1.2 & 1.1 & 1.45 & 44 & 0 & 201 & 201 & \\
\hline 37 & -116 & 1.2 & 1,2 & 1.45 & 44 & 0 & 199 & 199 & \\
\hline 37 & -116 & 1.2 & 1.3 & 1.45 & 44 & 0 & 196 & 196 & \\
\hline 37 & -116 & 1.2 & 1.4 & 1.45 & 44 & 0 & 194 & 190 & \\
\hline 37 & .116 & $1 \times 2$ & 1.5 & 1.45 & 44 & 0 & 191 & 191 & $2-2$ \\
\hline 37 & -116 & 1.2 & 1.6 & 1.45 & 44 & 0 & 189 & 189 & \\
\hline 37 & -116 & 1.2 & 1.7 & 1.45 & 44 & 0 & 186 & 186 & \\
\hline 37 & .116 & 1.2 & 1.8 & 1.45 & 44 & 0 & 184 & 184 & \\
\hline 37 & -116 & 1.2 & 1.9 & 1.45 & 44 & 0 & 182 & 182 & \\
\hline 37 & -116 & 12 & 2.0 & 1.45 & 44 & 0 & 179 & 179 & $3-3,4-3$ \\
\hline 37 & -116 & 1.2 & 2.1 & 1.45 & 44 & 0 & 177 & 177 & $5-4,6-4$ \\
\hline 37 & -116 & 1.2 & 2.2 & 1.45 & 44 & 0 & 175 & 175 & \\
\hline 37 & -116 & 1.2 & 2.3 & 1.45 & 44 & 0 & 172 & 172 & \\
\hline 37 & -116 & 1.2 & 2.4 & 1.45 & 4.4 & 0 & 170 & 170 & \\
\hline 37 & -116 & 1.2 & 2.5 & 1.45 & 44 & 0 & 168 & 168 & \\
\hline 37 & -116 & 1.2 & 2.6 & 1.45 & 44 & 0 & 166 & 166 & \\
\hline 37 & -116 & 1.2 & 2.7 & 1.45 & 44 & 0 & 164 & 164 & \\
\hline 37 & -116 & 1.2 & 2.8 & 1.45 & 44 & 0 & 162 & 162 & \\
\hline 37 & -116 & 1.2 & 2.9 & 1.45 & 44 & 0 & 160 & 160 & \\
\hline 37 & -116 & 1.2 & 3,0 & 1.45 & 44 & 0 & 158 & 158 & \\
\hline
\end{tabular}

Table $\mathrm{E}-2$. Cosmic ray dose-rate as functon of sample depth. Samples are indicated at their appropriate dephs in the last column.

\begin{tabular}{|c|c|c|c|c|c|c|c|c|}
\hline Sample Code & Beta & \pm & $\begin{array}{l}\text { Beta w } \\
\text { atten }\end{array}$ & \pm & Gamme & \pm & $\begin{array}{l}\text { Beta } \\
\text { Camma }\end{array}$ & $=$ \\
\hline BN STOS IB & 3.3 & 0.020 & 3.1 & 0.019 & 1.8 & 0.015 & 4.92 & 10.024 \\
\hline BN STO3 IB & 3.4 & 0.021 & 3.2 & 0.020 & 1.8 & 0.017 & 4.98 & 0.026 \\
\hline BN STO32B & 3.0 & 0.025 & 2.8 & 0.024 & 17 & 0.020 & 4.51 & 0.031 \\
\hline BN STO3 28 & 3.0 & 0.025 & 2.8 & 0.024 & 1.7 & 0.020 & 4.53 & 0.031 \\
\hline BN STO3 38 & 3.0 & 0.021 & 2.9 & 0.020 & 1.8 & 0.077 & 4.64 & 0.026 \\
\hline BN STO 338 & 3.1 & 0.021 & 2.9 & 0.021 & 18 & 0.017 & 4.68 & 0.027 \\
\hline BN STO $34 \mathrm{~B}$ & 3.0 & 0.022 & 2.8 & 0.021 & 1.7 & 0.018 & 4.52 & 0.028 \\
\hline BN STO3 $4 \mathrm{~B}$ & 3.0 & 0.023 & 2.8 & 0.022 & 1.7 & 0.019 & 4.53 & 0.029 \\
\hline
\end{tabular}

Tabe E-3. Beta and Gamma dosemates (Gy/ka) for water content $=0.0$ and beta atenuation due to finite grain size. 


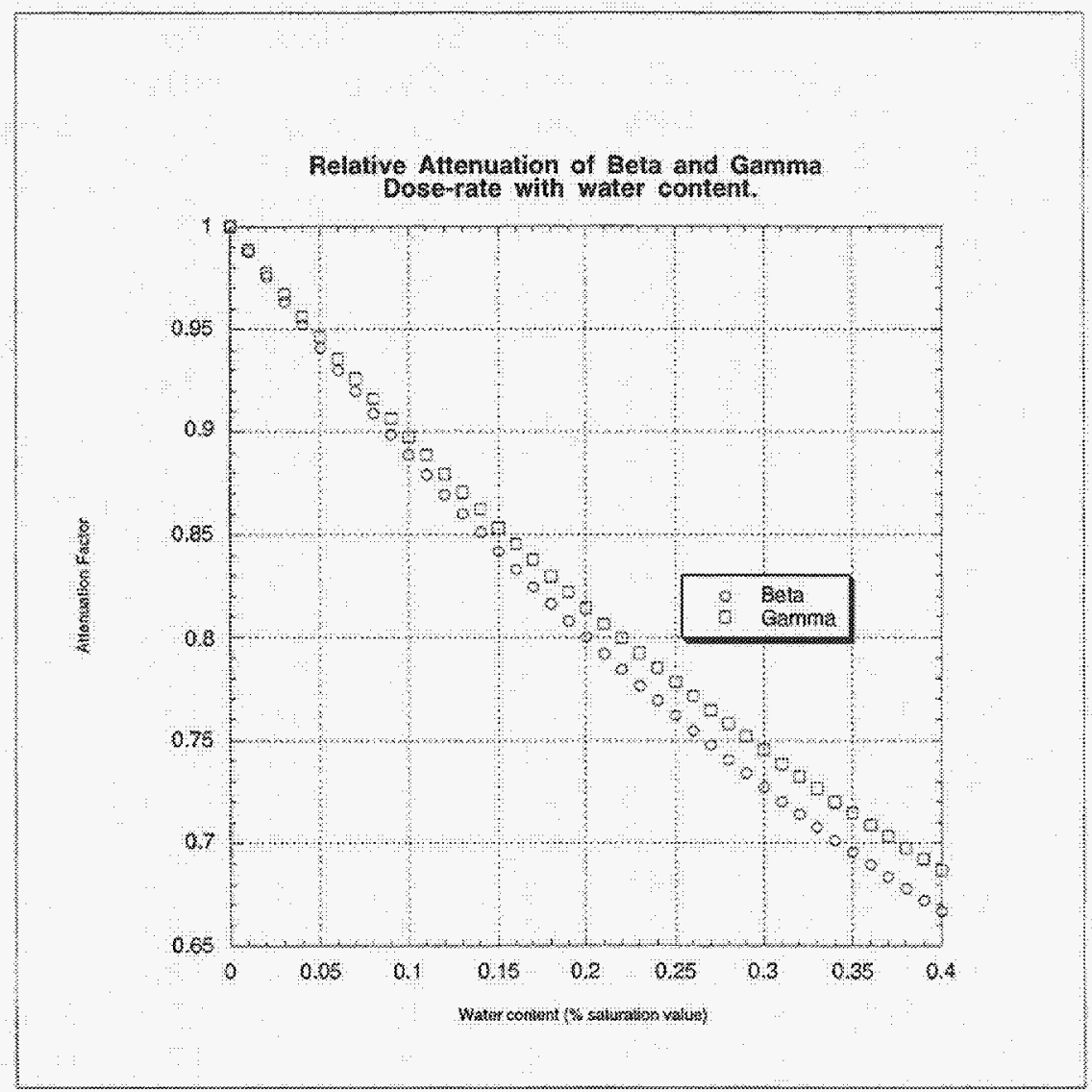

Tigure E-5. Relative attenuaton of beta and gamma dosemates with increasing water content.

\section{OSL results}

\begin{tabular}{|c|c|c|c|c|c|c|c|c|c|c|c|c|}
\hline & $1-1$ & $S E$ & $2-2$ & S.E & $3-3$ & SE & $4-3$ & $S E$ & $5-4$ & SE & $6 \cdot 4$ & S.E \\
\hline Wid & 38.4 & 0.1 & 41.6 & 0.8 & 54.6 & 0.9 & 55.4 & 0.0 & 57.7 & 0.8 & 53.5 & 10.5 \\
\hline Unwht & 46.0 & 2.1 & 38.3 & 1.9 & 52.9 & 2.3 & 55.7 & 2.4 & 53.5 & 11.4 & 60.8 & 2.4 \\
\hline Wha, Unwtd & 42.2 & 3.8 & 40.0 & 19.6 & 53.8 & 10.8 & 55.6 & 0.2 & 55.6 & 2.1 & 57.0 & 13.6 \\
\hline$n$ & 12 & & 12 & & 16 & & 16 & & 16 & & 20 & \\
\hline Outlers (Wid) & 0 & & 0 & & 0 & & 0 & & 0 & & 0 & \\
\hline Outlers (Unwtd) & 0 & & 1 & & 1 & & 2 & & 1 & & 1 & \\
\hline
\end{tabular}

Table E-4. Paloodose values (Gy). Weighted values are obtand by weighting individual dose measurements (D) in table () by the square of hein propogated uncertiny (sD).

\begin{tabular}{|l|r|}
\hline Wtd & 55.31 .8 \\
\hline Unwte & 55.73 .5 \\
\hline Wtd,Unwd & 55.51 .3 \\
\hline
\end{tabular}

Table E-5. Mean results of the Paleodose measurements for samples $3-3,4-3,544$, and 6-4 all taken from the same layer of Aedhan sand. The decision to use the average of the wnweighted and the weighted means of each sample as the "best estmate" of Paleodose was based on an analysis of the uncertamtes in the fou samples taken from the same layer. As secn in this figure, uncertanty assoctated with the averoge of the weighed and unweighed mans $(13)$ is lower thw wither that of the weighted mean $(13.5)$ 
Results of OSL dose analysis for each individual sample.

In the tables below, the OSL measurement of dose D $(G y)$ is detemined as follows.

$\mathrm{D}=\mathrm{A} * \mathrm{R} / \mathrm{S}$

where

$A=$ the laboratory applied dose ( $G y)$,

$\mathrm{R}=$ the ratio of the OSL output from the paleodose to that from the laboratory applied dose,

$S=$ the scaling factor described in the text.

$\mathrm{SS}=$ the standard error in the scaling factor

$\mathrm{sD}=$ the standard error in the dose estimate obtained by propogation of $\mathrm{S}$

\begin{tabular}{|c|c|c|c|c|c|}
\hline $1-1$ & & & & \\
\hline$A$ & $A$ & $S$ & $S$ & $D$ & $S D$ \\
\hline 56.7 & 0.872 & 0.8336 & 0.1721 & 59.3 & 12.2 \\
\hline 56.7 & 0.888 & 0.9330 & 0.0454 & 54.0 & 2.6 \\
\hline 56.7 & 0.668 & 1.0798 & 0.0191 & 35.1 & 0.6 \\
\hline 56.7 & 0.765 & 0.9710 & 0.0154 & 44.7 & 0.7 \\
\hline 44.1 & 0.933 & 0.8556 & 0.0558 & 48.1 & 3.1 \\
\hline 44.1 & 0.932 & 0.8420 & 0.0808 & 48.8 & 4.7 \\
\hline 44.1 & 1.032 & 0.8998 & 0.0126 & 50.6 & 0.7 \\
\hline 44.1 & 0.764 & 0.9962 & 0.0107 & 33.8 & 0.4 \\
\hline 44.1 & 0.871 & 0.8683 & 0.0393 & 44.2 & 2.0 \\
\hline 44.1 & 0.707 & 0.7001 & 0.0976 & 44.5 & 6.2 \\
\hline 44.1 & 0.893 & 0.8547 & 0.0691 & 46.1 & 3.7 \\
\hline 44.1 & 0.759 & 0.7884 & 0.0804 & 42.5 & 4.3 \\
\hline
\end{tabular}

Table $\mathrm{E}-6$. Paleodose values for indwidual measurements of 5 ample $1-1$.

\begin{tabular}{|c|c|c|c|c|c|}
\hline $2-2$ & & & & & \\
\hline A & R & $S$ & 85 & $\mathrm{D}$ & $\mathrm{SD}$ \\
\hline 38.9 & 0.774 & 0.5998 & 0.0708 & 50.1 & 5.9 \\
\hline 38.9 & 0.891 & 0.4301 & 0.1067 & 80.4 & 20.0 \\
\hline 38.9 & 0.731 & 0.7290 & 0.0879 & 39.0 & 4.7 \\
\hline 38.9 & 0.769 & 0.7279 & 0.0455 & 41.0 & 2.6 \\
\hline 42.0 & 0.711 & 0.7592 & 0.0866 & 39.3 & 4.5 \\
\hline 42.0 & 0.572 & 0.7947 & 0.1513 & 30.2 & 5.8 \\
\hline 42.0 & 0.900 & 0.8717 & 0.0188 & 43.4 & 0.9 \\
\hline 42.0 & 0.610 & 0.8143 & 0.0997 & 31.5 & 3.9 \\
\hline 42.0 & 0.903 & 0.8744 & 0.0704 & 43.4 & 3.5 \\
\hline 42.0 & 0.629 & 0.6779 & 0.1077 & 39.0 & 6.2 \\
\hline 42.0 & 0.534 & 0.7155 & 0.1463 & 31.4 & 6.4 \\
\hline 42.0 & 0.550 & 0.6872 & 0.0606 & 33.6 & 3.0 \\
\hline
\end{tabular}

Table E-7. Paleodose values for individu measurements of Sample 2-2. The 80.4 Gy value was removed for the unwerghted mean 


\begin{tabular}{|c|c|c|c|c|c|}
\hline $3-3$ & \multicolumn{7}{c}{} & & \\
\hline$A$ & $R$ & $S$ & 5 & $D$ & $s D$ \\
\hline 34.7 & 1.008 & 0.9243 & 0.3209 & 37.8 & 13.1 \\
\hline 34.7 & 0.959 & 0.8554 & 0.0857 & 38.8 & 3.9 \\
\hline 34.7 & 1.030 & 0.7792 & 0.0463 & 45.8 & 2.7 \\
\hline 34.7 & 1.098 & 0.1738 & 0.2580 & 218.9 & 324.8 \\
\hline 52.5 & 1.013 & 0.8264 & 0.0225 & 64.3 & 1.8 \\
\hline 52.5 & 0.839 & 0.8720 & 0.0863 & 50.5 & 5.0 \\
\hline 52.5 & 0.841 & 0.9329 & 0.4435 & 47.4 & 22.5 \\
\hline 52.5 & 0.815 & 0.7069 & 0.3237 & 60.6 & 27.7 \\
\hline 56.7 & 0.823 & 0.7947 & 0.2451 & 58.7 & 18.1 \\
\hline 56.7 & 0.820 & 0.9538 & 0.1802 & 48.8 & 9.2 \\
\hline 56.7 & 0.767 & 0.8117 & 0.1024 & 53.6 & 6.8 \\
\hline 56.7 & 0.882 & 0.7099 & 0.1973 & 70.4 & 19.6 \\
\hline 56.7 & 0.715 & 0.8128 & 0.0358 & 49.9 & 2.2 \\
\hline 56.7 & 0.621 & 0.6104 & 0.0354 & 57.7 & 3.3 \\
\hline 56.7 & 0.675 & 0.6927 & 0.0318 & 55.3 & 2.5 \\
\hline 56.7 & 0.643 & 0.6668 & 0.0322 & 54.7 & 2.6 \\
\hline
\end{tabular}

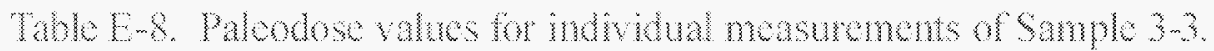

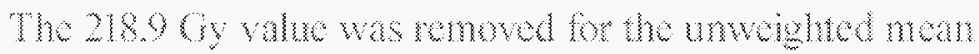

\begin{tabular}{|c|c|c|c|c|c|}
\hline $4-3$ & & & & \\
\hline$A$ & $F$ & $S$ & $s$ & 0 & $s 0$ \\
\hline 44.1 & 0.829 & 0.7419 & 0.0509 & 49.3 & 3.4 \\
\hline 44.1 & 0.813 & 0.7752 & 0.1539 & 46.2 & 9.2 \\
\hline 44.1 & 0.737 & 0.6162 & 0.1244 & 52.8 & 10.7 \\
\hline 44.1 & 0.758 & 0.6416 & 0.101 & 52.1 & 8.2 \\
\hline 50.4 & 0.909 & 0.6402 & 0.1491 & 71.6 & 16.7 \\
\hline 50.4 & 0.933 & 1.0419 & 0.1578 & 45.1 & 6.8 \\
\hline 50.4 & 0.736 & 0.4325 & 0.1931 & 85.7 & 38.3 \\
\hline 50.4 & 0.812 & 0.6750 & 0.0678 & 60.7 & 6.1 \\
\hline 55.7 & 0.687 & 0.8116 & 0.1102 & 47.1 & 6.4 \\
\hline 55.7 & 0.942 & 0.8572 & 0.1509 & 63.2 & 10.8 \\
\hline 55.7 & 0.826 & 0.6173 & 0.2705 & 74.5 & 32.6 \\
\hline 55.7 & 0.774 & 0.6934 & 0.0307 & 62.1 & 2.7 \\
\hline 55.7 & 0.825 & 0.4097 & 0.2345 & 112.1 & 64.2 \\
\hline 55.7 & 0.745 & 0.7972 & 0.1421 & 52.0 & 0.3 \\
\hline 55.7 & 0.660 & 0.7284 & 0.1942 & 50.4 & 13.4 \\
\hline 55.7 & 0.683 & 0.6873 & 0.1014 & 55.3 & 8.2 \\
\hline
\end{tabular}

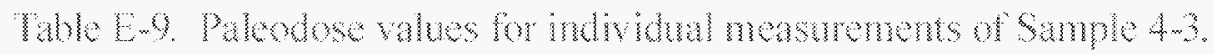

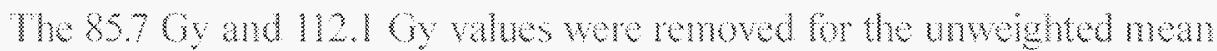




\begin{tabular}{|c|c|c|c|c|c|}
\hline 5.4 & \multicolumn{1}{|c|}{} & & & \\
\hline $\mathrm{A}$ & $\mathrm{R}$ & $\mathrm{S}$ & $\mathrm{S}$ & $\mathrm{D}$ & $\mathrm{s}$ \\
\hline 55.7 & 0.741 & 0.6676 & 0.0107 & 61.8 & 1.0 \\
\hline 55.7 & 0.735 & 0.7359 & 0.0859 & 55.6 & 6.5 \\
\hline 55.7 & 0.800 & 0.4405 & 0.3063 & 101.1 & 70.3 \\
\hline 55.7 & 0.593 & 0.5785 & 0.1638 & 57.0 & 16.1 \\
\hline 68.3 & 0.588 & 0.6912 & 0.0954 & 58.0 & 8.0 \\
\hline 68.3 & 0.599 & 0.8040 & 0.0360 & 50.8 & 2.3 \\
\hline 68.3 & 0.683 & 0.9226 & 0.1139 & 50.5 & 6.2 \\
\hline 68.3 & 0.607 & 0.7994 & 0.1268 & 51.8 & 8.2 \\
\hline 52.5 & 0.862 & 0.7896 & 0.1285 & 57.3 & 9.3 \\
\hline 52.5 & 0.624 & 0.7923 & 0.0778 & 41.4 & 4.1 \\
\hline 52.5 & 0.742 & 0.6537 & 0.1106 & 59.6 & 10.1 \\
\hline 52.5 & 0.778 & 0.8216 & 0.1009 & 49.7 & 6.1 \\
\hline 52.5 & 0.703 & 0.7792 & 0.0757 & 47.4 & 4.6 \\
\hline 52.5 & 0.791 & 0.7433 & 0.1027 & 55.9 & 7.7 \\
\hline 52.5 & 0.848 & 0.8179 & 0.1401 & 54.5 & 9.3 \\
\hline 52.5 & 0.834 & 0.8658 & 0.0560 & 50.6 & 3.3 \\
\hline
\end{tabular}

Table E-10, Daleodose values for ind vidual measurements of Sample 5 -4. The 101.1 Gy value was remoyed hr the unweighted mean

\begin{tabular}{|c|c|c|c|c|c|}
\hline $6-4$ & & & & & \\
\hline$A$ & $B$ & $S$ & $s S$ & $D$ & $s D$ \\
\hline 52.5 & 1.077 & 0.8844 & 0.1629 & 63.9 & 11.8 \\
\hline 52.5 & 0.904 & 0.9930 & 0.0693 & 47.8 & 3.3 \\
\hline 52.5 & 0.832 & 0.8428 & 0.0130 & 51.8 & 0.8 \\
\hline 52.5 & 0.811 & 0.9213 & 0.0615 & 46.2 & 3.1 \\
\hline 48.3 & 0.834 & 0.8789 & 0.1509 & 45.8 & 7.9 \\
\hline 48.3 & 0.742 & 0.5731 & 0.1394 & 62.6 & 15.2 \\
\hline 48.3 & 0.795 & 0.7456 & 0.0203 & 51.5 & 1.4 \\
\hline 48.3 & 0.702 & 0.6210 & 0.0078 & 54.6 & 0.7 \\
\hline 56.7 & 0.662 & 0.4914 & 0.1867 & 76.3 & 29.0 \\
\hline 56.7 & 0.897 & 0.9007 & 0.0918 & 56.5 & 5.8 \\
\hline 56.7 & 0.681 & 0.5171 & 0.0934 & 74.6 & 13.5 \\
\hline 56.7 & 0.971 & 0.9193 & 0.1007 & 59.9 & 6.6 \\
\hline 56.7 & 0.789 & 0.9189 & 0.0448 & 48.7 & 2.4 \\
\hline 56.7 & 0.790 & 0.6282 & 0.0756 & 71.3 & 8.6 \\
\hline 56.7 & 1.008 & 0.9033 & 0.0514 & 63.3 & 3.6 \\
\hline 56.7 & 0.785 & 0.7458 & 0.2052 & 59.7 & 16.4 \\
\hline 60.5 & 0.760 & 0.5909 & 0.2075 & 77.8 & 27.3 \\
\hline 60.5 & 0.906 & 0.6085 & 0.1813 & 90.0 & 26.8 \\
\hline 60.5 & 0.849 & 0.7750 & 0.0627 & 66.3 & 5.4 \\
\hline 60.5 & 0.705 & 0.5835 & 0.0304 & 73.1 & 3.8 \\
\hline
\end{tabular}

Table L-1. Paloodose values for indidual measurements of Sample 64 .

The $900 \mathrm{GY}$ value was removed or the unweighted mean 


\begin{tabular}{|c|c|c|c|c|c|c|}
\hline \multicolumn{6}{|c|}{ Age as function of water content (Avg of Whd and Mean values) } & \multirow[b]{2}{*}{$6-4$} \\
\hline $\mathrm{H2O}$ & $1-1$ & $2-2$ & $3 \cdot 3$ & $4-3$ & $5-4$ & \\
\hline 0.00 & 8.18 & 8.48 & 11.29 & 11.67 & 11.68 & 11.97 \\
\hline 0.01 & 8.27 & 8.58 & 11.43 & 11.81 & 11.81 & 12.11 \\
\hline 0.02 & 8.36 & 8.68 & 11.56 & 11.95 & 11.95 & 12.25 \\
\hline 0.03 & 8.46 & 8.78 & 11.69 & 12.08 & 12.08 & 12.39 \\
\hline 0.04 & 8.55 & 8.88 & 11.82 & 12.21 & 12.22 & 12.53 \\
\hline 0.05 & 8.65 & 8.97 & 11.95 & 12.35 & 12.36 & 12.67 \\
\hline 0.06 & 8.74 & 9.07 & 12.08 & 12.49 & 12.49 & 12.81 \\
\hline 0.07 & 8.94 & 9.17 & 12.21 & 12.62 & 12.62 & 12.94 \\
\hline 0.08 & 8.93 & 9.27 & 12.34 & 12.76 & 12.76 & 13.08 \\
\hline 0.09 & 9.02 & 9.36 & 12.47 & 12.89 & 12.89 & 13.22 \\
\hline 0.10 & 9.12 & 9.46 & 12.60 & 13.02 & 13.03 & 13.36 \\
\hline 0.11 & 9.21 & 9.56 & 12.73 & 13.16 & 13.16 & 13.49 \\
\hline 0.12 & 9.31 & 9.66 & 2.86 & 13.29 & 13.30 & 13.63 \\
\hline 0.13 & 9.40 & 9.75 & 12.99 & 13.43 & 13.43 & 13.77 \\
\hline 0.14 & 9.49 & 9.85 & 13.12 & 13.56 & 13.57 & 13.91 \\
\hline 0.15 & 9.59 & 9.95 & 13.25 & 13.69 & 13.70 & 14.04 \\
\hline 0.16 & 9.68 & 10.05 & 13.38 & 13.83 & 13.83 & 14.18 \\
\hline 0.17 & 9.77 & 10.14 & 13.51 & 13.96 & 13.97 & 14.32 \\
\hline 0.18 & 9.87 & 0.24 & 13.64 & 14.10 & 14.10 & 14.46 \\
\hline 0.19 & 9.96 & 10.34 & 13.77 & 14.23 & 14.24 & 14.59 \\
\hline 0.20 & 10.05 & 10.43 & 13.90 & 14.36 & 14.37 & 14.73 \\
\hline 0.21 & 10.15 & 10.53 & 14.02 & 14.49 & 14.50 & 14.87 \\
\hline 0.22 & 10.24 & 10.62 & 14.15 & 14.63 & 14.63 & 15.00 \\
\hline 0.23 & 10.33 & 10.72 & 14.28 & 14.76 & 14,77 & 15.14 \\
\hline 0.24 & 10.42 & 10.82 & 14.411 & 14.89 & 14.90 & 15.28 \\
\hline 0.25 & 10.52 & 10.91 & 14.54 & 15.02 & 15.03 & 15.41 \\
\hline 0.26 & 10.61 & 11.01 & 14.67 & 15.16 & 15.17 & 15.55 \\
\hline 0.27 & 10.70 & 11.10 & 14.79 & 15.29 & 15.30 & 15.68 \\
\hline 0.28 & 10.79 & 11.20 & 14.92 & 15.42 & 15.43 & 15.82 \\
\hline 0.29 & 10.89 & 11.29 & 15.05 & 15.55 & 15.56 & 15.96 \\
\hline 0.30 & 10.98 & 11.39 & 15.18 & 15.69 & $\$ 5.70$ & 16.09 \\
\hline 0.31 & 11.07 & 11.49 & 15.31 & 15.82 & 15.83 & 16.23 \\
\hline 0.32 & 11.16 & 11.58 & 15.44 & 15.95 & 15.96 & 16,36 \\
\hline 0.33 & 11.25 & 11.68 & 15.56 & 16.08 & 16.09 & 16.50 \\
\hline 0.34 & 11.35 & 11.77 & 15.69 & 16.21 & 16.22 & 16.63 \\
\hline 0.35 & 11.44 & 11.87 & 15.82 & 16.35 & 16.36 & 16.77 \\
\hline 0.36 & 11.53 & 11.96 & 15.94 & 16.48 & 16.49 & 16.90 \\
\hline 0.37 & 11.62 & 12.06 & 16.07 & 16.611 & 16.62 & 17.04 \\
\hline 0.38 & 11.71 & 12.15 & 16.20 & 16.74 & 16.75 & 17.17 \\
\hline 0.39 & 11.81 & 12.25 & 16.32 & 16.87 & 16.88 & 17.30 \\
\hline 0.6 & 11.90 & 12.34 & 16.45 & 17.00 & 17.01 & 17.44 \\
\hline
\end{tabular}

Table E-12. Age estonates (ks) as function ot water content br all samples 


\section{Mererences}

Aitken, MJ. (1985). Thermoluminescence Dating. Academic Press, Harcourt Brace Jovanovich. Publishers, London.

Lloyd, R. (1976). Camma ray emitters in concrete. Healh Physics 31, 71-73.

Prescott, L. Stephan, L. (1982) The contribution of cosmic radiation to the environmental dose for thermoluminescent dating. PACT 6, 17-25. 


\section{DISTRIBUTION}

\section{U.S. Department of Energy}

\section{Copies}

Jhon T. Carilli

Waste Management Project

Office of Environmental Management

U.S. Department of Energy

National Nuclear Security Administration

Nevada Site Office

P.O. Box $98518, \mathrm{M} / \mathrm{S} 505$

Las Vegas, NV 89193-8518

James J. Cebe

Waste Management Project

Office of Environmental Management

U.S. Department of Energy

National Nuclear Security Administration

Nevada Site Office

P.O. Box 98518, M/S 505

Las Vegas, NV 89193-8518

Angela P. Colarusso

Waste Management Project

Office of Environmental Management

U.S. Department of Energy

National Nuclear Security Administration

Nevada Site Office

P.O. Box 98518, M/S 505

Las Vegas, NV 89193-8518

Bruce M. Crowe

Apogen Technologies

U.S. Department of Energy

National Nuclear Security Administration

Nevada Site Office

P.O. Box 98518, M/S 505

Las Vegas, NV 89193-8518

U.S. Department of Energy

1 (CD)

National Nuclear Security Administration

Nevada Site Office

Technical Library

P.O. Box 98518, M/S 505

Las Vegas, NV 89193-8518 


\section{DISTRIBUTION (continued)}

\section{U.S. Department of Energy (cont.)}

Copies

U.S. Department of Energy

$1(\mathrm{CD})$

National Nuclear Security Administration

Nevada Site Office

Public Reading Facility

c/o Nuclear Testing Archive

P.O. Box $98521, \mathrm{M} / \mathrm{S} 400$

Las Vegas, NV 89193-8521

U.S. Department of Energy

1 (CD)

Office of Scientific and Technical Information

Post Office Box 62

Oak Ridge, TN 37831-0062 


\section{DISTRIBUTION (continued)}

National Security Technologies

Environmental Management Library

National Security Technologies, LLC

P.O. Box 98518, M/S NLV 094

Las Vegas, NV 89193-8521

Terry Brooker

National Security Technologies, LLC

P.O. Box 98518 , M/S NSF 080

Las Vegas, NV 89193-8521

Steve Nacht

National Security Technologies, LLC

P.O. Box 98518, M/S NSF 083

Las Vegas, NV 89193-8521

Stuart Rawlinson

National Security Technologies, LLC

P.O. Box $98521 \mathrm{M} / \mathrm{S}$ NTS416

Las Vegas, NV 89193-8521

Shirley Smith

National Security Technologies, LLC

P.O. Box 98518 , M/S NSF 080

Las Vegas, NV 89193-8521

Kathy Umbarger

National Security Technologies, LLC

P.O. Box 98518 , M/S NSF 083

Las Vegas, NV 89193-8521

\section{Copies}

$1(\mathrm{CD})$

$1(\mathrm{CD})$

1

1

1 (CD) 